DENISE GALLO PIZELLA

\title{
AS CONTRIBUIÇÕES DA AVALIAÇÃO AMBIENTAL ESTRATÉGICA PARA TOMADA DE DECISÕES SOBRE A LIBERAÇÃO COMERCIAL DE PLANTAS GENETICAMENTE MODIFICADAS NO BRASIL
}

Tese apresentada à Escola de Engenharia de São Carlos, como parte dos requisitos para obtenção do Título de Doutor em Ciências da Engenharia Ambiental.

Prof. Titular MARCELO PEREIRA DE SOUZA

Orientador

São Carlos - SP 
AUTORIZO A REPRODUÇÃO E DIVULGAÇÃO TOTAL OU PARCIAL DESTE TRABALHO, POR QUALQUER MEIO CONVENCIONAL OU ELETRÔNICO, PARA FINS DE ESTUDO E PESQUISA, DESDE QUE CITADA A FONTE.

Ficha catalográfica preparada pela Seção de Tratamento da Informação do Serviço de Biblioteca - EESC/USP

Pizzela, Denise Gallo

As contribuições da avaliação ambiental estratégica para tomada de decisões sobre a liberação comercial de plantas geneticamente modificadas no Brasil / Denise Gallo Pizzela ; orientador Marcelo Pereira de Souza. -São Carlos, 2010 .

Tese (Doutorado-Programa de Pós-Graduação e Área de concentração em Ciências da Engenharia Ambiental) -Escola de Engenharia de São Carlos da Universidade de São Paulo, 2010 .

1. Impactos ambientais - estudo. 2. Instrumentos ambientais. 3. Avaliação ambiental estratégica. 4. Análise de risco. 5. Plantas geneticamente modificadas. I. Título. 


\section{FOLHA DE JULGAMENTO}

Candidato(a): Bacharel DENISE GALLO PIZELLA.
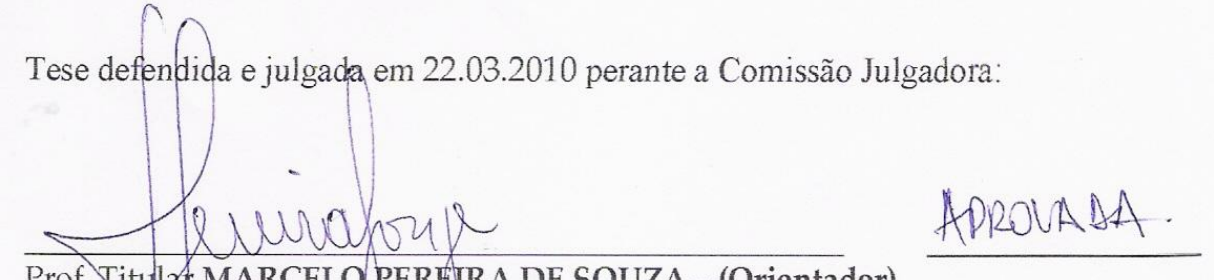

Prof. Titylar MARCELO PEREIRA DE SOUZA - (Orientador)

(Faculdade de Filosofia, Ciências e Letras de Ribeirão Preto/USP)

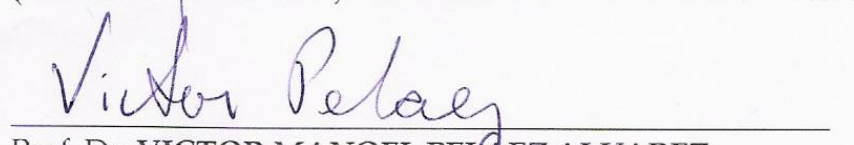

Prof. Dr. VICTOR MANOEL PELAEZ ALVAREZ

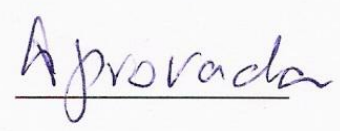

(Universidade Federal do Paraná/UFPR)

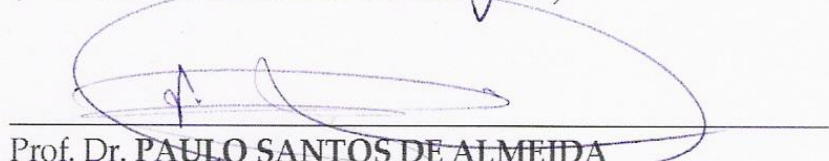

APROVADA

(Escola de Artes, Ciências e Humanídades/USP)

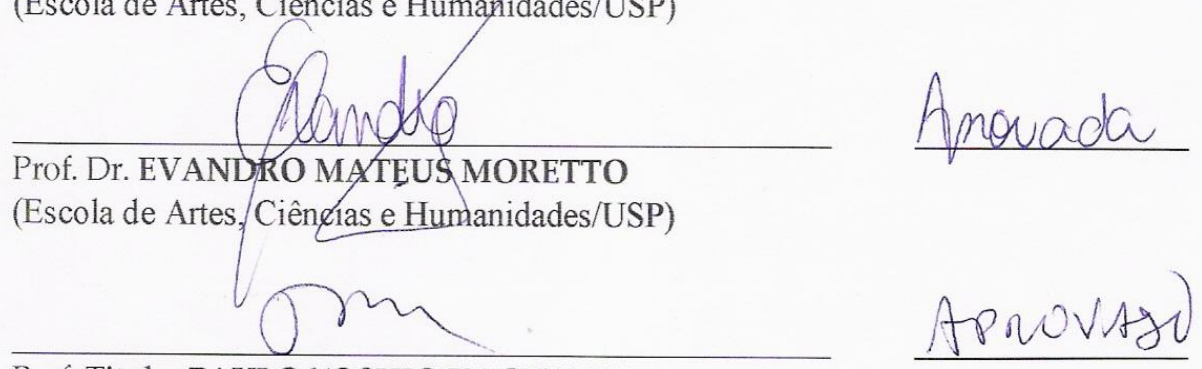

Prof. Titular PAULO YOSHIO KAGEYAMA

(Escola Superior de Agricultura "Luiz de Queiroz"/USP)

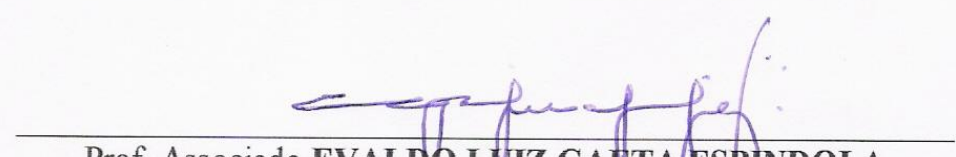

Prof. Associado EVALDO LUIZ GAETTA ESPINDOLA

Coordenador do Programa de Pós-Graduação em Ciências da Engenharia Ambiental

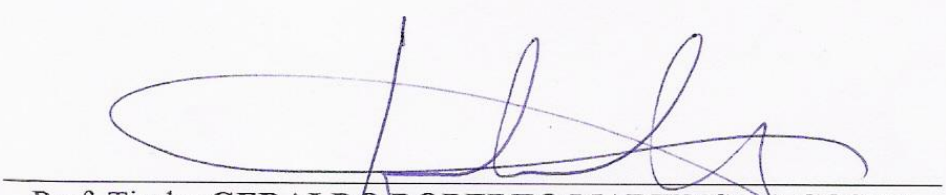

Prof. Titular GERALDO ROBERTO MARTINS DA COSTA Presidente da Comissão da Pós-Graduação da EESC 


\section{DEDICATÓRIA}

Dedico este trabalho a todos que, direta ou indiretamente, colaboraram em sua elaboração, com especial atenção ao Vagner, minha família, ao Marcelo e amigos. 


\section{AGRADECIMENTOS}

Agradeço, sobretudo, ao Professor Marcelo pela dedicação ao trabalho, ensinamentos, amizade e pelo exemplo de luta.

À minha família pelo apoio permanente, sobretudo minha mãe, avó, Adriana, tios, Luis e Dani.

Ao Vagner pelo carinho e companheirismo.

A todos os meus amigos, especialmente ao Aurélio, pelos constantes auxílios. Também à Eliane, Gabriel, Karina, Silvia, Fran, Adriano, Janaína, Clarinha, Angela, Zenaide, Rafael, Émerson, Mirian, Neto e Mariana.

Ao Professor Moacyr Lobo da Costa Júnior da Escola de Enfermagem do campus da USP de Ribeirão Preto, pelo auxílio com o questionário.

À Isabel, pelas preciosas discussões.

A todos os respondentes do questionário, que colaboraram muito para com este trabalho.

A todos os docentes, diretores e presidentes da pós-graduação do Centro de Recursos Hídricos e Ecologia Aplicada da EESC-USP, como os professores Marcelo, Evaldo, Victor, dentre outros.

À Claudete e ao Nelson, também do CRHEA, pela amizade e prestatividade em todos estes anos.

À Capes pela bolsa de fomento concedida. 


\section{RESUMO}

PIZELLA, D.G. As contribuições da Avaliação Ambiental Estratégica para tomada de decisões sobre a liberação comercial de Plantas Geneticamente Modificadas no Brasil. 2009. 243 f. Tese (Doutorado) - Escola de Engenharia de São Carlos, Universidade de São Paulo, São Paulo, 2009.

A liberação comercial de plantas geneticamente modificadas (PGMs) é assunto controverso, devido ao desconhecimento quanto aos potenciais impactos ambientais e sócioeconômicos que pode suscitar a curto, médio e longo prazo. De modo a regular as deliberações sobre o uso de organismos geneticamente modificados (OGMs) mecanismos regulatórios que se propõem a prever tais impactos estão sendo criados em diversas nações, sendo a análise de risco (AR) o instrumento de estudo ambiental normalmente empregado nos processos decisórios. No entanto, há contestações sobre seu uso como única ferramenta de análise ambiental de PGMs, já que não possibilita a avaliação dos impactos cumulativos, indiretos, de longo prazo e dos interesses das nações delineados em suas políticas, planos e programas (PPPs). Um instrumento proposto por alguns autores passível de abarcar tais considerações é a Avaliação Ambiental Estratégica, que busca inserir a variável ambiental durante as fases de planejamento que resultam na elaboração de PPPs. Este trabalho teve como objetivo avaliar o sistema regulatório envolvendo a liberação em escala comercial de PGMs no Brasil e as potenciais contribuições da AAE para o processo decisório, contemplando os princípios de uma boa governaça ambiental nos processos decisórios. Para tanto, aplicou-se um questionário eletrônico a agentes sociais interessados pelo tema visando identificar suas visões sobre o assunto, analisou-se os procedimentos utilizados na deliberação sobre o algodão MON1445 resistente ao herbicida glifosato e, por fim, efetuou-se a avaliação dos instrumentos análise de risco, estudo de impacto ambiental (EIA) e AAE quanto à inserção da variável ambiental nas tomadas de decisão. Os resultados obtidos foram: com relação ao sistema regulatório, cujos pressupostos encontram-se na Lei de Biossegurança, evidenciou-se a falta de legitimidade nas tomadas de decisão, as quais são realizadas pela CTNBio, enquanto que a Constituição brasileira atribui aos órgãos ambientais a deliberação sobre atividades potencialmente poluidoras, dentre estas aquelas que envolvam OGMs; a deficiência dos mecanismos de participação social, pois as audiências públicas ocorrem mediante decisão da CTNBio; a falta de acesso às informações, devido a não implementação do Sistema de Informações sobre Biossegurança (SIB), além do descumprimento de diversas legislações, que configuram no desrespeito à justiça ambiental. Em razão destes fatores, conclui-se que o sistema regulatório brasileiro sobre PGMs não se baseia em uma boa governança ambiental. Quanto aos instrumentos de avaliação de impactos ambientais, a análise de risco, em função dos aspectos acima levantados, não se adequa para a avaliação prévia de PGMs, podendo ser utilizada como uma metodologia que subsidie o EIA ou a AAE. O EIA, por sua vez, não tem a atribuição de avaliar ações que envolvam territórios abrangentes, mas sim de atividades pontuais que se dão em etapas posteriores de planejamento. Já a AAE contribuiria para a tomada de decisões no tocante à liberação comercial de PGMs, em função de seus princípios de transparência, envolvimento social, planejamento ambiental, abrangência de extensos recortes territoriais, avaliação de impactos cumulativos e de longo prazo e monitoramento ambiental contínuo. Deste modo, recomendou-se a utilização da AAE no planejamento ambiental envolvendo liberações comerciais de PGMs no Brasil.

Palavras-chave: Instrumentos ambientais. Estudo de Impacto Ambiental. Avaliação Ambiental Estratégica. Análise de Risco. Plantas Geneticamente Modificadas. 


\begin{abstract}
PIZELLA, D.G. Contributions of Strategic Environmental Assessment for decisionmaking on commercial release of Genetically Modified Crops in Brazil. 2009. 260f. Tese (Doutorado) - Escola de Engenharia de São Carlos, Universidade de São Paulo, São Paulo, 2009.
\end{abstract}

The commercial release of genetically modified crops (GMCs) is controversial, due to the lack of knowledge about the potential environmental and socio-economic impacts that can lead to short, medium and long term. In order to regulate the deliberations on the use of genetically modified organisms (GMOs), regulatory mechanisms that are proposed to predict such impacts are being created in many nations, with risk analysis (RA) being the instrument normally used in environmental studies for decision-making. However, there are some doubts about its use as the only tool of environmental analysis of PGMs, since it does not allow the assessment of cumulative, indirect and long-term impacts and the interests of the nation outlined in their policies, plans and programs (PPPs). An instrument proposed by some authors likely to embrace such considerations is the Strategic Environmental Assessment, which seeks to insert the environmental variable during the planning stages that result in the development of PPPs. This thesis aimed to evaluate the regulatory system involving the commercial release of GMCs in Brazil and the potential contribution of SEA to decisionmaking process, incorporating the principles of good governance. To this end, we applied an electronic questionnaire to some social actors to identify their views on the subject, reviewed the procedures used in the deliberation of the glyphosate-resistant cotton MON1445 and, finally, we performed the evaluation of risk analysis, environmental impact statement (EIS) and SEA as tools of environmental parameter insertion in decision-making. The results obtained were: with respect to the regulatory system, whose assumptions are in the Biosafety Law, there was a lack of legitimacy in decision-making, which are held by CTNBio, while the Brazilian Constitution assigns the decision on potentially polluting activitities (among which is those related to the GMOs) to the environmental agencies; the deficiency of the mechanisms of social participation, since decisions for public hearings are taking by CTNBio; lack of access to information due to non-implementation of the Information Biosafety System (IBS), and the disrespect of various laws, whith disregard for environmental justice. Because of these factors, the Brazilian regulatory system on PGMs is not based on good environmental governance. With regard to instruments for environmental studies, risk analysis, according to the aspects mentioned above, is not suitable for prior assessment of GMCs and can be used as a methodology that assists EIS or SEA. The EIS, in turn, does not have the assignment to assess actions that involve extensive territories, but the pontual activities that take place in later stages of planning. SEA, in turn, would contribute to the decision-making regarding the commercial release of GMPs, according to its principles of transparency, social involvement, environmental planning, coverage of extensive territorial areas, assessment of cumulative and long-term impacts and continuous environmental monitoring. Thus, recommendations were made for the use of SEA in environmental planning involving commercial releases of GMPs in Brazil.

Keywords: Environmental tools. Environmental Impact Statement. Strategic Environmental Assessment. Risk Analysis. Genetically Modified Crops. 


\section{LISTA DE TABELAS}

Tabela 1 - Informações de Biossegurança requeridas pelo RMA ZN para agentes de controle biológico, novas plantas e plantas transgências.

Tabela 2 - $\quad$ Pareceres das Subcomissões setoriais da CTNBio sobre o Algodão Roundup Ready (RR) evento MON 1445.

Tabela 3 - $\quad$ Parecer final da CTNBIO sobre o Algodão Roundup Ready (RR) evento MON 1445.

Tabela 4 Percentual de respostas em função dos questionários enviados por categorias.

Tabela 5 - Frequências e porcentagens dos respondentes por categorias de atuação.

Tabela 6 - Consideração de outras Políticas, Planos e Programas para a liberação de PGMs.

Tabela 7 - Consideração de outras Políticas, Planos e Programas para a liberação de PGMs segundo cada categoria.

Tabela 8 - Agentes sociais que devem participar das decisões sobre a liberação de PGMs (para a totalidade dos respondentes).

Tabela 9 - $\quad$ Agentes sociais que devem participar das decisões sobre a liberação de PGMs, segundo a categoria 01 (Biotecnologia e Biossegurança).

Tabela 10 - Agentes sociais que devem participar das decisões sobre a liberação de PGMs, segundo a categoria 01 (Direito e Regulamentação).

Tabela 11 - Agentes sociais que devem participar das decisões sobre a liberação de PGMs, segundo a categoria 01 (Ecologia).

Tabela 12 - Agentes sociais que devem participar das decisões sobre a liberação de PGMs, segundo a categoria 01 (Meio Ambiente).

Tabela 13 - Agentes sociais que devem participar das decisões sobre a liberação de PGMs, segundo a categoria 01 (ONGs).

Tabela 14 - Instituições que devem participar da tomada de decisões sobre a liberação de PGMs (para a totalidade dos respondentes).

Tabela 15 - Instituições que devem participar da tomada de decisões sobre a liberação de PGMs, segundo a categoria 01(Biotec, Biossegurança). 


\section{LISTA DE TABELAS}

Tabela 16 - Instituições que devem participar da tomada de decisões sobre a

liberação de PGMs, segundo a categoria 02 (Direito e Regulamentação).

Tabela 17 - Instituições que devem participar da tomada de decisões sobre a liberação de PGMs, segundo a categoria 03 (Ecologia).

Tabela 18 - Instituições que devem participar da tomada de decisões sobre a liberação de PGMs, segundo a categoria 04 (Meio Ambiente).

Tabela 19 - Instituições que devem participar da tomada de decisões sobre a liberação de PGMs, segundo a categoria 05 (ONGs).

Tabela 20 - Adequação do EIA/RIMA para a AIA de PGMs (para todos os respondentes).

Tabela 21 - Adequação do EIA/RIMA para a AIA de PGMs, segundo a categoria 01 (Biotecnologia e Biossegurança).

Tabela 22 - Adequação do EIA/RIMA para a AIA de PGMs, segundo a categoria 02 (Direito e Regulamentação).

Tabela 23 - Adequação do EIA/RIMA para a AIA de PGMs, segundo a categoria 03 (Ecologia).

Tabela 24 - Adequação do EIA/RIMA para a AIA de PGMs, segundo a categoria 04 (Meio Ambiente).

Tabela 25 - Adequação do EIA/RIMA para a AIA de PGMs, segundo a categoria 05 (ONGs).

Tabela 26 - Adequação da Análise de Risco para a AIA de PGMs (para todos os respondentes.

Tabela 27 - Adequação da Análise de Risco para a AIA de PGMs, segundo a 99 categoria 01 (Biotecnologia e Biossegurança).

Tabela 28 - Adequação da Análise de Risco para a AIA de PGMs, segundo a categoria 02 (Direito e Regulamentação).

Tabela 29 - Adequação da Análise de Risco para a AIA de PGMs, segundo a categoria 03 (Ecologia).

Tabela 30 - Adequação da Análise de Risco para a AIA de PGMs, segundo a categoria 04 (Meio Ambiente).

Tabela 31- Adequação da Análise de Risco para a AIA de PGMs, segundo a categoria 05 (ONGs). 


\section{LISTA DE TABELAS}

Tabela 32- Na AIA de PGMs, qual a importância dos seguintes aspectos (para todos os respondentes):

Tabela 33 - Na AIA de PGMs, qual a importância dos seguintes aspectos, segundo a categoria 01 (Biotecnologia e Biossegurança).

Tabela 34 - Na AIA de PGMs, qual a importância dos seguintes aspectos, segundo a categoria 02 (Direito e Regulamentação).

Tabela 35 - Na AIA de PGMs, qual a importância dos seguintes aspectos, segundo a categoria 03 (Ecologia).

Tabela 36 - Na AIA de PGMs, qual a importância dos seguintes aspectos, segundo a categoria 04 (Meio Ambiente).

Tabela 37 - Na AIA de PGMs, qual a importância dos seguintes aspectos, segundo a categoria 05 (ONGs).

Tabela 38 - Avaliação do processo decisório sobre PGMs no Brasil (para todos os respondentes).

Tabela 39 - Avaliação do processo decisório sobre PGMs no Brasil, segundo a categoria 01 (Biotecnologia e Biossegurança).

Tabela 40 - Avaliação do processo decisório sobre PGMs no Brasil, segundo a categoria 02 (Direito e Regulamentação).

Tabela 41 - Avaliação do processo decisório sobre PGMs no Brasil, segundo a categoria 03 (Ecologia).

Tabela 42 - Avaliação do processo decisório sobre PGMs no Brasil, segundo a categoria 04 (Meio Ambiente).

Tabela 43 - Avaliação do processo decisório sobre PGMs no Brasil, segundo a categoria 05 (ONGs).

Tabela 44 - Diferenças entre o Estudo de Impacto Ambiental e a Avaliação Ambiental Estratégica.

Tabela 45 - Passos da AAE comumente utilizados na avaliação de Planos e Programas.

Tabela 46 Comparação entre Análise de Risco, Estudo de Impacto Ambiental e Avaliação Ambiental Estratégica em função de critérios necessários à avaliação de impactos ambientais. 


\section{LISTA DE SIGLAS}

AAE

AIA

APHIS

ANPA

AR

ASEAN

CDB

CEQ

CETESB

CFIA

CIBio

CNBS

CONAMA

CQB

CRADA

CTNBio

EC

EIA

EIS

EFSA

EMBRAPA

FAO

FDA
Avaliação Ambiental Estratégica

Avaliação de Impacto Ambiental

Animal and Plant Health Inspection Service

Associação Nacional dos Pequenos Agricultores

Análise de Risco

Association of Southeast Asean Nations

Convenção sobre Diversidade Biológica

Council on Environmental Quality

Companhia Ambiental do Estado de São Paulo

Canadian Food Inspection Agency

Comissão Interna de Biossegurança

Conselho Nacional de Biossegurança

Conselho Nacional do Meio Ambiente

Certificado de Qualidade em Biossegurança

Cooperative Research and Development Agreement

Comissão Técnica Nacional de Biossegurança

Environmental Canada

Estudo de Impacto Ambiental

Environmental Impact Statement

European Food Safety Authority

Empresa Brasileira para a Pecuária e Agricultura

Food and Agriculture Organization of The United Nations

Food and Drug Administration 


\section{LISTA DE SIGLAS}

FIFRA

FFDCA

FPPA

EPA

IBAMA

IDEC

IPCC:

GMO ERA

GMs

GRAS

GTEC

GTMC

GTTAC

GTCCC

$\mathrm{HC}$

MAPA

MDA

MMA

MS

MPF

NEPA

$\mathrm{NIH}$

OECD

OGMs
Federal Insecticide, Fungicide and Rodenticide Act

Federal Food, Drug and Cosmetic Act

Federal Plant Pest Act

Environmental Protection Agency

Instituto Brasileiro do Meio Ambiente e dos Recursos Naturais Renováveis

Instituto de Defesa do Consumidor

International Plant Protection Convention

Genetically Modified Organism Environmental Risk Analysis

Geneticamente Modificados

Generally Recognized as Safe

Gene Technology Ettics Committee

Gene Technology Ministerial Council

Gene Technology Technical Advisory Committee

Gene Technology Community Consultative Committee

Health Canada

Ministério da Agricultura, Pecuária e Abastecimento

Ministério do Desenvolvimento Agrário

Ministério do Meio Ambiente

Ministério da Saúde

Ministério Público Federal

National Environmental Policy Act

National Institute of Health

Organisation for Economic Cooperation and Development

Organismos Geneticamente Modificados 


\section{LISTA DE SIGLAS}

$\mathrm{OMC}$

OMS

OSHA

PGMs

PNB

PNMA

PNUMA

PPPs

PRONAF

RIMA

SIB

SISNAMA

TSCA

EU

UNECE

USDA
Organização Mundial de Comércio

Organização Mundial de Saúde

Occupational Safety and Health

Plantas Geneticamente Modificadas

Política Nacional de Biossegurança

Política Nacional do Meio Ambiente

Programa das Nações Unidas para o Meio Ambiente

Políticas, Planos e Programas

Programa Nacional de Agricultura Familiar

Relatório de Impacto Ambiental

Sistema de Informações em Biossegurança

Sistema Nacional do Meio Ambiente

Toxic Substances Control Act

União Européia

United Nations Economic Comission for Europe

United States Department of Agriculture 


\section{LISTA DE GRÁFICOS}

Gráfico 1. Consideração de outras Políticas, Planos e Programas para a 88 liberação de PGMs.

Gráfico 2. Agentes sociais que devem participar das decisões sobre a 89 liberação de PGMs (para a totalidade dos respondentes).

Gráfico 3. Instituições que devem participar da tomada de decisões sobre a liberação de PGMs (para a totalidade dos respondentes).

Gráfico 4. Adequação do EIA/RIMA para a AIA de PGMs.

Gráfico 5. Adequação da Análise de Risco para a AIA de PGMs.

Gráfico 6. Na AIA de PGMs, qual a importância dos seguintes aspectos (para todos os respondentes).

Gráfico 7. Avaliação do processo decisório sobre PGMs no Brasil, segundo os critérios (para todos os respondentes). 


\section{LISTA DE FIGURAS}

Figura 1. Área Global com lavouras GMs. $\quad 2$

Figura 2. Área global com lavouras GMs, 1996 a 2008, por lavoura. $\quad$ 2

$\begin{array}{lll}\text { Figura 3. Representação de impacto indireto. } & 133\end{array}$

Figura 4. Representação de impacto cumulativo resultante da combinação de $\mathbf{1 3 4}$ um mesmo tipo de impacto.

Figura 5. Representação de impacto cumulativo resultante da interação entre impactos diferentes.

Figura 6. Relações hierárquicas entre Políticas, Planos, Programa e Projetos.

Figura 7. Ligação (ou não) entre os estágios de tomadas de decisão estratégica e as fases da AAE - círculos simbolizam os estágios e as flechas indicam as relações. (a) e (b) não são modelos de boas práticas, enquanto que (c) e (d) são considerados modelos de "boas práticas".

Figura 8. Metodologia para Avaliação Ambiental Estratégica de pesquisas sobre OGMs.

Figura 9. Estágios da ação estratégica e a forma como estes podem ser influenciados pela AAE.

Figura 10. Processo atual que conduz à estratégia de liberação comercial de PGMs

Figura 11. Consideração de Leis e PPPs que fazem interface com a estratégia de liberação comercial de PGMs, possibilitada pela AAE.

Figura 12. Processo de deliberação sobre uma proposta de liberação comercial de planta geneticamente modificada e as contribuições da AAE.

Figura 13. Proposta de liberação comercial de planta geneticamente modificada sem a utilização da AAE.

Figura 14. Aplicações da AAE e do EIA em diferentes situações de liberação de PGMs e suas interfaces com a Análise de Risco. 


\section{SUMÁRIO}

1. INTRODUÇÃO 1

$\begin{array}{ll}2 . & \text { OBJETIVOS }\end{array}$

$\begin{array}{lll}\text { 2.1. } & \text { Objetivo Geral }\end{array}$

$\begin{array}{lll}\text { 2.2. } & \text { Objetivos Específicos }\end{array}$

$\begin{array}{llr}\text { 3. } & \text { METODOLOGIA }\end{array}$

4. BIOTECNOLOGIA MODERNA, SUAS APLICAÇÕES E 10 CONFLITOS.

4.1. Origem da biotecnologia moderna, opiniões da sociedade sobre seu uso $\mathbf{1 0}$ e potenciais impactos ambientais e sócio-econômicos.

4.2. Tratados internacionais sobre o tema: Programa das Nações Unidas para o Meio Ambiente e o Protocolo de Cartagena sobre Biossegurança

4.3. Sistemas regulatórios sobre OGMs em alguns países e comunidades de 25 referência.

4.3.1. Estados Unidos da América.

4.3.2. União Européia

4.3.3. Canadá.

4.3.4. Austrália e Nova Zelândia.

5. REGULAÇÃO DE OGMS NO BRASIL.

5.1. Histórico.

5.2. Aspectos institucionais e conflitos: normas, participação, acesso às informações e justiça ambiental.

5.2.1. Conflitos de normas.

5.2.2. Órgãos constituintes e participação social. 


\section{SUMÁRIO}

5.2.3. Aspectos relacionados à justiça ambiental.

5.2.4. Instrumentos de estudos ambientais.

5.3. Algodão Roundup Ready (RR) evento MON 1445: empresa Monsanto do Brasil

5.4. Considerações sobre os aspectos que nortearam a deliberação da 77 CTNBio sobre o algodão RR da Monsanto.

5.5. Questionário para sistematizar as opiniões de setores da sociedade

6. POLÍTICA E INSTRUMENTOS AMBIENTAIS.

6.1. Governança ambiental e OGMs.

6.2. Análise de Risco: conceituação.

6.3. Avaliação de Impactos Ambientais: origem e tipologias.

6.3.1. Estudo de Impacto Ambiental: conceito, origem e procedimentos.

6.3.2. Avaliação Ambiental Estratégica: conceito, origem e procedimentos.

6.4. Os instrumentos de estudos ambientais e suas potencialidades e fragilidades para a liberação de PGMs em escala comercial.

6.4.1. Análise de Risco.

6.4.2. $\quad$ O Estudo de Impacto Ambiental.

7. A Avaliação Ambiental Estratégica e a tomada de decisões sobre a 196 liberação em escala comercial de PGMs.

8. CONCLUSÕES. 


\section{INTRODUÇÃO}

O cultivo e comercialização de Plantas Geneticamente Modificadas (PGMs) na agricultura é assunto permeado de controvérsias (STIRLING, 2007; GUIVANT, 2006) sendo necessários mecanismos regulatórios que sejam capazes de abarcar as implicações ambientais, sociais, éticas, culturais e econômicas advindas de sua utilização. A polarização da questão se dá em função das incertezas quanto aos impactos potenciais do uso da biotecnologia moderna ${ }^{1}$ sobre a saúde humana e dos demais animais e ao meio ambiente, incluindo a manutenção da diversidade agrícola e, consequentemente, à segurança alimentar; às implicações sociais relativas às práticas agrícolas e estrutura fundiária das nações; às relações comerciais nacionais e internacionais; aos direitos de escolha dos consumidores e aos valores sociais e ambientais da sociedade de modo geral. A despeito de tais controvérsias, as plantações geneticamente modificadas apresentam um crescimento acentuado em todo o mundo desde sua liberação comercial nos EUA no início da década de 90, com predominância de variedades tolerantes a herbicidas e com propriedades inseticidas, sendo soja, milho, algodão e canola os cultivos mais comumente utilizados (BROOKES; BARFOOT, 2005), como representado nas Figuras 1 e 2.

\footnotetext{
${ }^{1}$ De acordo com o Protocolo de Cartagena sobre Biossegurança (BRASIL, 2003, art. $3^{\circ}$.), entende-se por "biotecnologia moderna":

a. a aplicação de técnicas in vitro de ácidos nucleicos, inclusive ácido desoxirribonucleico (ADN) recombinante e injeção direta de ácidos nucleicos em células ou organelas, ou

b. a fusão de células de organismos que não pertencem à mesma família taxonômica, que superem as barreiras naturais da fisiologia da reprodução ou da recombinação e que não sejam técnicas utilizadas na reprodução e seleção tradicionais.
} 


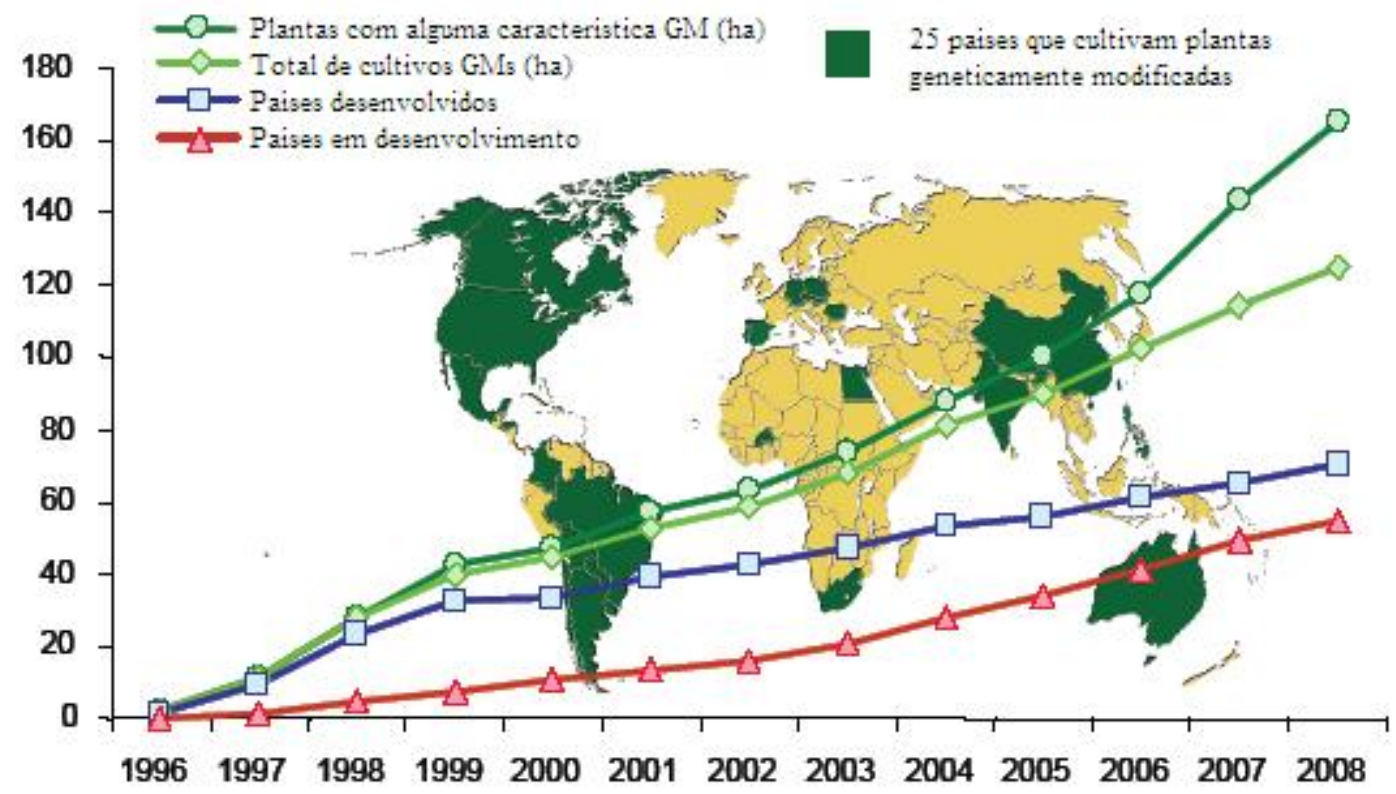

Um aumento "aparente" de 9,4\% ou 10,7 milhões de hectares entre 2007 e 2008, equivalente a um aumento "real" de 15\% ou 22 milhões de hectares de cultivos geneticamente modificados (incluindo genes piramidados).

Figura 1- Área Global com lavouras GMs.

Fonte: Modificado de James (2009).

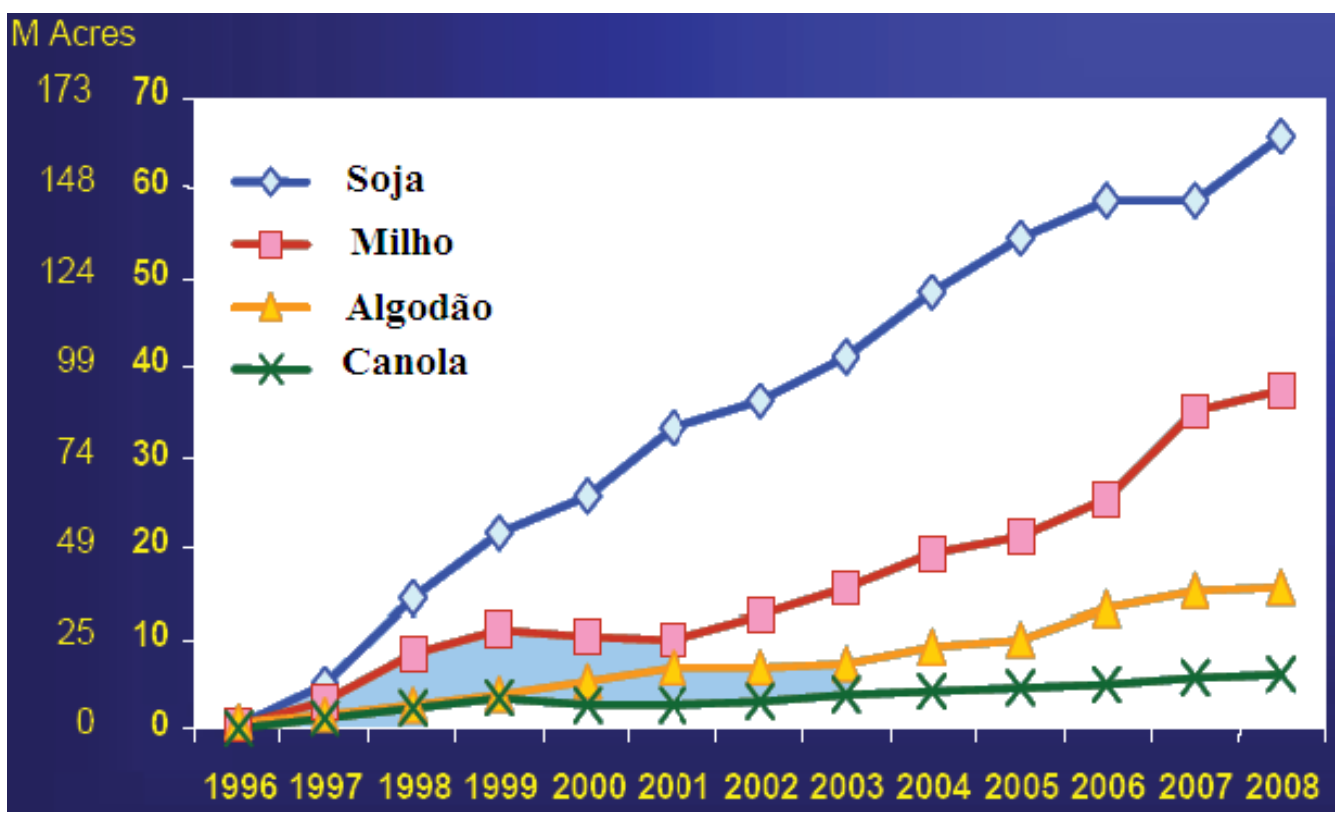

Figura 2 - Área global com lavouras GMs, 1996 a 2008, por lavoura. Fonte:Modificicado de James (2009).

Atualmente, os oito maiores produtores mundiais de PGMs são os EUA, com uma área plantada de 64 milhões de hectares, seguidos pelo Brasil, com 21,4 milhões de ha, 
Argentina, com 21,3 milhões de ha, Índia com 8,4 milhões de ha, Canadá, com 8,2 milhões de ha, China, com 3,7 milhões de ha, Paraguai, com 2,2 milhões de ha e África do Sul, com 2,2 milhões de ha (INTERNATIONAL SERVICE FOR THE ACQUISION OF AGRI-BIOTECH APPLICATIONS, 2008).

Diversas organizações internacionais e nações vêm estabelecendo marcos regulatórios de caráter mandatário ou orientador a respeito dos organismos geneticamente modificados (OGMs). Em âmbito global, destaca-se o Protocolo de Cartagena sobre Biossegurança, concebido em 2000 pela Conferência das Partes sobre a Convenção da Biodiversidade, tendo por objetivo:

[...] assegurar um nível adequado de proteção no campo da transferência, da manipulação e do uso seguros dos organismos vivos modificados resultantes da biotecnologia moderna que possam ter efeitos adversos na conservação e no uso sustentável da diversidade biológica, levando em conta os riscos para a saúde humana, e enfocando especificamente os movimentos transfronteiriços.

(BRASIL, 2003, art.1 ${ }^{\circ}$.)

O Protocolo tem como premissa a vigência do princípio da precaução nos processos decisórios sobre OGMs, dadas as incertezas científicas sobre os possíveis impactos ambientais, econômicos e sociais advindos de sua utilização e adota a análise de risco como ferramenta de avaliação caso-a-caso. Apesar de o foco do Protocolo ser as relações transfronteiriças, diversas nações o utilizam como um modelo orientador na elaboração de normas de biossegurança internas para as pesquisas e comercialização dos OGMs. Similarmente, outras organizações internacionais, como a OECD (Organisation for Economic Cooperation and Development), FAO (Food and Agriculture Organisation of The United Nations), o PNUMA (Programa das Nações Unidas sobre Meio Ambiente), o IPPC (International Plant Protection Convention), a ASEAN (Association of Southeast Asean Nations) e a União Européia têm adotado a abordagem de avaliação de risco caso-a-caso para cada cultivo geneticamente modificado (GM), como forma de se detectar os possíveis riscos que tais organismos possam acarretar à saúde e ao meio ambiente. O mesmo se sucede para com os países que adotaram normatizações sobre biossegurança, como EUA, Canadá, Austrália, Nova Zelândia, Argentina, África do Sul, China, Índia, Brasil, dentre outros.

Não obstante as especificidades de cada nação quanto à abordagem de avaliação de impactos ambientais de OGMs, destaca-se a repercussão internacional dos modelos de 
regulação dos Estados Unidos da América (EUA) e da União Européia (UE), os quais, dada à extensão de suas relações comerciais e influência política global, passam a ser adaptados às mais diversas realidades nacionais. De modo geral, as diferenças entre os modelos derivam das premissas utilizadas na gestão dos OGMs. Enquanto nos EUA eles são considerados substancialmente equivalentes às variedades convencionais desenvolvidas pelas técnicas de hibridização sendo, portanto, tão seguros quanto sua contraparte convencional, na UE o cultivo geneticamente modificado é considerado um novo organismo, com características e impactos potenciais únicos e em cuja gestão se aplica o princípio da precaução. Tal princípio, balizador de grande parte da legislação ambiental mundial se faz presente na Declaração sobre Meio Ambiente e Desenvolvimento de 1992.

A utilização deste princípio pela UE não implica a proibição do uso de plantas geneticamente modificadas para fins agrícolas, havendo inclusive o reconhecimento da liberdade de escolha do produtor em adotar o sistema de plantio que melhor lhe convenha, seja transgênico, convencional ou orgânico. No entanto, admitindo-se as incertezas acerca do comportamento das PGMs nos locais de liberação (o qual se encontra intimamente ligado às características ambientais, escala de produção e práticas agrícolas especificas), assim como a necessidade de se garantir a coexistência entre as formas de cultivo, adotam-se medidas mais cautelosas para a liberação ambiental, além de se executar um monitoramento pós-comercial obrigatório. Para os defensores da precaução na gestão de OGMs, a modificação genética envolvendo a transferência de genes entre espécies de reinos diferentes é passível de alterar os mecanismos biológicos do organismo receptor e suas relações com os fatores bióticos e abióticos presentes no ambiente em que houver a liberação. As incertezas científicas a respeito disto e os impactos ambientais potenciais e à saúde humana justificam, deste modo, a necessidade de uma análise de risco mais criteriosa (HENRY, 2006).

Dentre os riscos ambientais e à saúde advindos da liberação de PGMs, destacam-se, no presente trabalho, aqueles provenientes de sua introdução em larga escala e longo prazo, passíveis de ocasionarem impactos indiretos e cumulativos. Autores como Hindmarsh (1990), Stirling (2000), Whales e Mythen (2002), Ely (2002) e Henry (2006) questionam as atuais abordagens de Análise de Risco e os Estudos de Impactos Ambientais como ferramentas únicas de avaliação de impactos ambientais de OGMs, em razão das dificuldades destes instrumentos em identificar e avaliar os impactos cumulativos, indiretos e de longo prazo resultantes do cultivo de OGMs em larga escala, de liberações coincidentes no espaço envolvendo diferentes tipos de OGMs e dos impactos iniciados após o término dos cultivos, difíceis de serem detectados sem um monitoramento ambiental contínuo. 
Neste sentido, Linacre et al (2005) e Pessôa (2007) levantam as oportunidades do uso de ferramentas de análise capazes de lidar com escalas geográficas e temporais mais extensas, com enfoque no planejamento e participação social, tais como a Avaliação Ambiental Estratégica (AAE), que vem sendo utilizada mundialmente para avaliar os impactos ambientais de Políticas, Planos e Programas (PPPs) propostos pelos governos ou organizações privadas, em função dos benefícios que tráz ao planejamento territorial por adotar as seguintes premissas (DALAL-CLAYTON; SADLER, 1995; SADLER; BAXTER, 1997, apud DALAL-CLAYTON; SADLER, 2005):

$\checkmark \quad$ inserção da sustentabilidade ambiental nos processos decisórios, integrando as diversas dimensões do desenvolvimento (econômica, social, ambiental, política e cultural);

$\checkmark \quad$ consideração de alternativas locacionais, tecnológicas e programáticas às PPPs propostas, dificilmente abordadas nas avaliações pontuais, de empreendimentos;

$\checkmark \quad$ análise de impactos cumulativos, indiretos e de longo prazo, não detectados em atividades pontuais;

$\checkmark \quad$ aprimoramento da capacidade institucional na detecção de impactos e de sua consideração nas fases iniciais de planejamento, facilitando a análise dos impactos no âmbito dos projetos;

$\checkmark \quad$ melhoria da coordenação entre setores governamentais no processo de elaboração de PPPs;

auxílio no delineamento das atividades pontuais, em razão da incorporação de objetivos e metas ambientais em políticas, planos e programas que sirvam de base para a elaboração de projetos que considerem de antemão a dimensão ambiental, a identificação prévia dos impactos e das informações necessárias para a avaliação de projetos, além da redução do tempo e dos esforços para a realização de revisões;

$\checkmark \quad$ engajamento do público interessado e diretamente afetado no processo de elaboração de PPPs.

O Brasil possui um sistema regulatório de OGMs ancorado na Lei de Biossegurança de 2005, utilizando a análise de risco como instrumento de estudo ambiental previamente às deliberações sobre a utilização destes organismos (BRASIL, 2005). Assim como nas demais nações, a questão dos transgênicos no Brasil é bastante polêmica, dividindo opiniões em todos os setores sociais (VEIGA, 2007; GUIVANT, 2006). Neste sentido, torna-se pertinente uma análise da governança ambiental do sistema que regula as atividades que utilizam tais organismos no país, já que a governança diz respeito ao modo como a sociedade lida com assuntos de interesse coletivo, sendo uma boa governança dotada dos seguintes pressupostos: 
acesso do público à participação social, às informações e à justiça, prestação de contas, transparência, dentre outros, por parte das instituições tomadoras de decisão e encarregadas de implementá-las, tais como os governos e organizações informais (COMMONWEALTH OF AUSTRALIA, 2000; PETKOVA; PAPA; TAYAB, 2006; GOODWIN et al., apud COCKLIN; DIBDEN; GIBBS, 2008). Deste modo, tendo em vista o contexto do sistema regulatório de OGMs no Brasil, especificamente com relação aos instrumentos de estudos ambientais adotados para as tomadas de decisão a respeito da liberação comercial de plantas geneticamente modificadas, o presente trabalho se propõe a analisá-los do ponto de vista de uma boa governança ambiental, assim como identificar as potenciais contribuições da AAE para o processo decisório. 


\section{OBJETIVOS}

\subsection{Objetivo geral:}

Avaliar o sistema regulatório de OGMs no Brasil e as possíveis contribuições da AAE para a tomada de decisão sobre a liberação comercial de PGMs.

\subsection{Objetivos específicos:}

Verificar a presença de conflitos sociais relacionados ao sistema regulatório de OGMs no Brasil.

Avaliar as potencialidades da Análise de Risco e os instrumentos de avaliação de impactos ambientais, quais sejam, o Estudo de Impacto Ambiental/Relatório de Impacto Ambiental e a Avaliação Ambiental Estratégica, em lidar com os conflitos suscitados. 


\section{METODOLOGIA}

Para a consecução dos objetivos propostos, a metodologia adotada no presente trabalho é a seguinte:

Revisão bibliográfica da literatura pertinente, contendo:

A história da biotecnologia e as opiniões existentes sobre sua utilização;

* Os princípios e procedimentos do Protocolo de Cartagena, por se configurar em um guia para a implementação de mecanismos regulatórios nas nações que o ratificaram;

* Exemplos internacionais de sistemas relatórios de OGMs, como os Estados Unidos da América e a União Européia, que recebem destaque por influenciarem as demais nações quanto a elaboração de procedimentos regulatórios;

* O sistema regulatório de OGMs no Brasil;

* Os princípios para uma boa governança ambiental;

* Os instrumentos empregados para a avaliação de impactos de PGMs destinadas à liberação comercial, tais como a análise de risco e os estudos de impacto ambiental;

* O instrumento de Avaliação de Impactos Ambientais "Avaliação Ambiental Estratégica" e exemplos de sua aplicação em processos decisórios envolvendo PGMs ou OGMs em geral, se existentes.

Visando a identificação de conflitos presentes no sistema regulatório das Plantas Geneticamente Modificadas no Brasil foram efetuados:

* Revisão bibliográfica sobre este aspecto;

* Análise do processo decisório de uma PGM liberada no Brasil, qual seja, o Algodão Roundup Ready, evento MON1445, desenvolvido pela empresa Monsanto. A análise teve por objetivo identificar a maneira como os pareceres realizados pelos membros das Câmaras Setoriais da Comissão Técnica Nacional de Biossegurança e os comentários da audiência pública influenciaram no Parecer final da Comissão. Para tanto, foram contemplados:

- O parecer dos membros das Câmaras Setoriais da CTNBio;

- Os questionamentos e informações abordados na audiência pública do algodão;

- O parecer final da CTNBio sobre o processo. 
Os critérios para a análise se basearam nas questões abordadas nos pareceres e na audiência pública.

* A aplicação de questionários a especialistas em diversas áreas de conhecimento, tais como biotecnologia, biossegurança, direito, regulamentação, ecologia e meio ambiente, além de organizações não-governamentais relacionadas ao assunto. $\mathrm{O}$ questionário buscou identificar a opinião dos respondentes sobre o sistema regulatório de PGMs brasileiro e os instrumentos de avaliação ambiental utilizados, com abertura para sugestões. Por se tratar de um tema polêmico, optou-se pela manutenção do anonimato dos respondentes, visando evitar potenciais constrangimentos de ordem pessoal e a inviabilização na obtenção de respostas. Neste sentido, os questionários foram enviados por correspondência eletrônica no período de fevereiro de 2008 a agosto de 2009. Uma avaliação quantitativa e qualitativa sobre as questões foi conduzida, envolvendo a porcentagem e frequiência de respostas. Para tanto, utilizou-se o Sistema de Processamento de Texto, Banco de Dados e Estatística para Epidemiologia em Microcomputadores "Epi Info" Versão 06, de domínio público e desenvolvido pela Organização Mundial de Saúde e pelo Centro de Controle e Prevenção de Doenças (CDC). Tal programa foi empregado por sua rapidez no processamento de dados em análises estatísticas. O detalhamento da metodologia será apresentada no item 5.3.

$\checkmark$ Os instrumentos de estudos ambientais em análise, ou seja, a Análise de Risco, o Estudo de Impacto Ambiental e a Avaliação Ambiental Estratégica foram avaliados segundo os parâmetros:

* Consideração de impactos indiretos e cumulativos;

* Escala territorial de abrangência;

* Interface com Políticas, Planos e Programas relacionados;

* Consideração de alternativas tecnológicas, locacionais e de desenvolvimento;

* Possibilidade de participação social nas tomadas de decisão;

Monitoramento ambiental. 


\section{A BIOTECNOLOGIA MODERNA, SUAS APLICAÇÕES E CONFLITOS}

Os organismos geneticamente modificados, também denominados de transgênicos, se derivam de uma célula possuidora de um genoma modificado pela adição de DNA exógeno, sendo este originado a partir de uma sequência manipulada de uma mesma espécie ou de outra espécie que tenha alguma propriedade desejável. O gene proveniente de DNA exógeno recebe o nome de transgene e dá-se o nome de biotecnologia moderna à área de pesquisa que aplica técnicas de DNA recombinante com fins científicos ou comerciais (GRIFFITHS et al., 1998).

Serão abordados neste capítulo a origem da biotecnologia, as opiniões existentes sobre seu uso, especificamente em relação a sua aplicação na agricultura, seus impactos potenciais, o Protocolo de Cartagena, que se apresenta como um guia para a regulação de movimentos transfronteiriços de transgênicos e alguns exemplos de sistemas regulatórios de OGMs no mundo.

\subsection{Origem da biotecnologia moderna, opiniões da sociedade sobre seu uso e potenciais impactos ambientais e sócio-econômicos.}

Na década de 1970 o termo "biotecnologia" popularizou-se em função dos avanços em biologia celular e molecular, originando a engenharia genética (NOSSAL, 1987 apud JESUS; PLONSKI, 2006). Com a descoberta das endonucleases de restrição, a manipulação do material genético dos eucariotos foi possibilitada. Concomitantemente, surgiram os vetores de clonagem de DNA, sondas genéticas que permitiram identificar sequências genéticas, técnicas que controlam a transcrição e expressão genética de organismos superiores que são introduzidos em bactérias e leveduras, além do bioprocessamento, que possibilita isolar e purificar os produtos derivados da engenharia genética. Segundo a OECD, "a Biotecnologia trata da aplicação de princípios científicos e de engenharia para o processamento de agentes e materiais biológicos para prover bens e serviços" (BULL et al., 1982 apud JESUS; PLONSKI, 2006, p.27).

As primeiras PGMs foram desenvolvidas na década de 1980, a partir da descoberta de que a bactéria do solo Agrobacterium tumefaciens poderia ser utilizada para a transferência de transgenes (PESSÔA, 2007).

Segundo Pessôa (2007), a utilização das técnicas de biotecnologia no melhoramento de plantas caracteriza-se pela obtenção das características desejadas em um tempo menor, ao 
contrário dos métodos convencionais, não havendo a necessidade de compatibilidade entre as espécies envolvidas, tornando possível a inserção do gene de uma espécie em outra. Existem diversas técnicas de inserção de DNA, tais como transformação, infecção viral, injeção ou partículas disparadas de tungstênio (GRIFFITHS, 1998), sendo as mais utilizadas na produção de Plantas Geneticamente Modificadas a utilização de vetores virais e a biobalística (GROSSI DE SÁ; ROMANO, 2003). Mas, independentemente do método adotado, é importante que os genes introduzidos possuam sequências regulatórias que permitam sua expressão correta. Tais sequências são principalmente o gene promotor e o sinal de terminação, sendo que o primeiro determina o local e o momento em que o gene de interesse será expresso na planta, se durante a floração ou germinação no botão floral, folhas, ou e/ou outros tecidos. O promotor mais utilizado em PGMs é o 35S, proveniente do vírus-do-mosaico-da-couve-flor, denominado de promotor constitutivo, por expressar-se em todos os tecidos da planta.

Outra sequência regulatória fundamental é o gene terminador, com a função de sinalizar o término da transcrição do gene de interesse. Deste modo, um transgene constitui-se de três elementos: o promotor, o gene de interesse e o terminador, os quais, em conjunto, denominam-se “cassete de expressão” (GROSSI DE SÁ; ROMANO, 2003).

Para que o transgene seja inserido na planta a ser modificada, a qual é denominada de "receptora", as técnicas acima mencionadas podem ser utilizadas (por meio de vetores virais, geralmente plasmídios, biobalística ou outras). Quando aplicado o método de vetores, estes possuem um gene marcador de seleção que, em sua grande maioria, é um gene resistente a antibióticos ou herbicidas. A função deste gene é identificar as células transgênicas por meio da aplicação do antibiótico ao qual o gene marcador possui resistência. Deste modo, as células que não forem afetadas pelo antibiótico ou herbicida serão as transgênicas. A necessidade do uso de genes marcadores se dá em função do reduzido número de células que realmente recebem o gene exógeno, dentre as milhares que passam pelo processo de transformação (GROSSI DE SÁ; ROMANO, 2003).

Depois de realizada a modificação genética, faz-se necessário o desenvolvimento da planta a partir de uma ou mais células transgênicas, a fim de que todas as células da futura PGM carreguem uma cópia do transgene. Para tanto, cultiva-se a(s) célula(s) em meios de cultura adequados, contendo nutrientes e hormônios específicos, em um processo denominado de cultura de tecidos (KADIR, 2002 apud PESSÔA, 2007).

As principais características transgênicas aplicadas na agricultura atualmente são aquelas que tenham utilidade aos produtores rurais, reduzindo os custos de produção por meio da diminuição do uso de agroquímicos. Consequentemente, as maiores variedades 
desenvolvidas são PGMs resistentes a herbicidas e a insetos, que fazem parte da primeira geração de transgênicos. Já a segunda geração consiste em plantas com melhor qualidade nutricional, enquanto que a terceira geração apresenta plantas que sintetizam produtos especiais, tais como biofármacos, polímeros naturais biodegradáveis e hormônios de mamíferos (NODARI; GUERRA, 2001, apud PESSÔA, 2007).

O cultivo em larga escala de PGMs iniciou-se em 1996 nos EUA com a soja resistente a herbicidas, sendo que por volta desta época, a área mundial plantada com OGMs chegou a 2,8 milhões de ha, distribuídos em somente seis países. Já em 2006, a área total chegou a 102 milhões de ha. Entre 1996 a 2006, os cultivos mais expressivos concentraram-se nas maiores commodities agrícolas, tais como soja, milho, canola e algodão. Não obstante a existência de PGMs com características resistentes a vírus, as variedades mais produzidas permanecem as resistentes a herbicidas e a insetos. Em 2005, 68\% da área mundial cultivada com PGMs consistia em variedades tolerantes a herbicidas, $18 \%$ resistentes a insetos e $12 \%$ apresentando uma combinação das duas características (SILVEIRA; BUAINAIN, 2007).

As PGMs tolerantes a herbicidas caracterizam-se por apresentar genes de resistência a estes agrotóxicos, tais como o glifosato e o glufosinato de amônio, sendo as plantas modificadas mais comuns a soja, canola, milho e algodão. As empresas desenvolvedoras destas culturas GMs vendem aos produtores rurais o pacote tecnológico contendo a planta e o herbicida que age sobre as plantas invasoras (ROBIN, 2008). Já as PGMs tolerantes a insetos apresentam transgenes produtores de agrotóxicos, tendo em vista a eliminação de pragas agrícolas. A maior parte das variedades produzidas possuem o gene $\mathrm{Bt}$, encontrado na bactéria de solo Agrobacterium tumefasciens, cujas espécies alvo são lepidópteros. As culturas transgênicas deste tipo mais comuns são o algodão e o milho (GROSSI DE SÁ; ROMANO, 2003).

Não existe um consenso no meio científico e na sociedade em geral acerca dos benefícios e riscos associados aos transgênicos, sendo o tema multifacetado, abrangendo questões de cunho ambiental, social e econômicas diversificadas, em um alcance mundial. Segundo Silveira e Buainain (2007) e Levidow (2008) tal polêmica não resulta apenas de ideologias retrógradas ou progressistas, mas de uma séria controvérsia científica, não se tratando de verdades e mentiras que transparecem nos meios de comunicação. A natureza incerta dos potenciais impactos dos OGMs, cujos riscos são indefinidos, já que a existência de riscos se dá diante de perigos que sejam mais ou menos perceptíveis, contribuem para as discórdias acerca de sua liberação no meio ambiente. 
Em geral, existem três posições dominantes neste debate. Uma que defende a liberação ambiental para fins comerciais de PGMs sem a necessidade de avaliação de seus impactos, outra totalmente contrária à aplicação da transgenia na produção de alimentos e uma posição intermédia, estando as duas últimas ancoradas sobre as incertezas existentes quanto aos riscos e benefícios dela derivados. Os argumentos apresentados por seus agentes serão brevemente comentados. Os setores sociais favoráveis à liberação sem restrições baseiam suas opiniões nas seguintes premissas (STIRLING, 1999; SILVEIRA; BUAINAIN, 2007; LEVIDOW, 2007):

$\checkmark$ A idéia da tecnologia como uma importante ferramenta para solucionar o problema da fome nos países subdesenvolvidos ou em desenvolvimento, em função da maior rentabilidade destes cultivos, por conta da diminuição do uso de agroquímicos, que diminuem os custos de produção.

A diminuição do uso de agroquímicos e da fronteira agrícola proporcionadas por seu uso, conduzindo a uma gestão agrícola mais sustentável ambientalmente, com a redução da contaminação do solo, das águas superficiais e subterrâneas e do ar (ocasionada pela aspersão destes insumos);

$\checkmark$ A promoção de uma maior segurança à saúde do trabalhador rural, devido ao uso reduzido de agroquímicos;

Uma maior precisão da inserção do material exógeno no DNA receptor em relação às técnicas de melhoramento convencional e a consequente expressão das características desejadas de forma mais adequada;

$\checkmark$ A equivalência substancial das variedades transgênicas com suas contrapartes convencionais, em termos de características nutricionais e componentes orgânicos, tais como proteínas, carboidratos e lipídeos. Deste modo, o transgene não provoca alterações nestas características;

A estabilidade genética, ou seja, a permanência do transgene em seu local de inserção é garantida por várias gerações, o que torna o risco de escape gênico improvável de ocorrer;

Apesar da maior produção de PGMs resistentes a insetos e herbicidas, o desenvolvimento de variedades com maior valor nutritivo, tal como o arroz com teor aumentado de vitamina A (a segunda geração de transgênicos) e produtoras de substâncias de interesse à saúde, como biofármacos e hormônios humanos são promessas das novas gerações de PGMs; 
$\checkmark$ A possibilidade de coexistência entre as variedades transgênicas, convencionais e dos demais sistemas "alternativos" de plantio, não havendo risco de contaminação destes por meio de escape gênico, desde que as culturas sejam manejadas corretamente;

$\checkmark$ A possibilidade de adotar outros sistemas de cultivo caso a PGM se tornar improdutiva ou ocasionar impactos ambientais e sociais significativos;

$\checkmark$ A minimização do monopólio tecnológico pelas multinacionais se houver investimentos nos órgãos de pesquisa nacionais ligados à biotecnologia;

$\checkmark$ A rotulagem dos produtos que contenham OGMs é desnecessária por razões econômicas, já que o consumidor pode, com receio de adquirir estes produtos, preferir os alimentos que não contenham transgênicos;

$\checkmark$ A avaliação da biossegurança das PGMs é uma questão técnica que deve ser tratada apenas pelos especialistas em biotecnologia e biossegurança;

No Brasil, é necessária uma produção maior de PGMs, a fim de que possa competir economicamente com as demais nações que as comercializam.

Os agentes sociais que apresentam pontos de vista contrários ou precaucionistas às liberações comerciais de PGMs, por sua vez, adotam os seguintes argumentos (ALTIERI; NICHOLLS, 2000; ROBIN, 2008):

$\checkmark$ A introdução do transgene no local desejado é incerta pelos métodos empregados, assim como sua expressão, que depende da localização no DNA receptor e das potenciais interações com os demais genes. Deste modo, proteínas desconhecidas podem surgir e suas consequências à saúde e ao meio ambiente são imprevisíveis;

$\checkmark$ As técnicas de melhoramento convencional são mais precisas para a escolha da variedade com as características desejadas. A isto se soma o fato de indivíduos compatíveis sexualmente serem utilizados, diminuindo-se o risco do surgimento de proteínas desconhecidas;

A quebra da barreira genética pela introdução de genes provenientes de organismos de espécies e reinos diferentes traz consequências desconhecidas, já que rompe com os mecanismos evolutivos de adaptação das espécies;

Há incertezas quanto aos potenciais riscos e significância dos impactos ambientais, sociais e econômicos da nova tecnologia;

$\checkmark$ Existem evidências de impactos diretos, indiretos e cumulativos que se manifestaram em todos os países em que as PGMs vêm sendo cultivadas;

$\checkmark$ Dentre os potenciais impactos negativos, os mais significativos relacionam-se à perda da biodiversidade agrícola e selvagem em função do escape do transgene; a resistência das 
plantas daninhas aos inseticidas aplicados e dos insetos aos agrotóxicos produzidos pela PGM e a manifestação de alergias provenientes da ocorrência de novas proteínas;

$\checkmark$ O monopólio das empresas produtoras de sementes transgênicas ocasiona a dependência do agricultor, o qual não pode utilizar os grãos obtidos para plantio posterior, em virtude do patenteamento da tecnologia. Deste modo, pode haver danos à soberania agrícola das nações;

$\checkmark$ A contaminação das sementes orgânicas tem levado à perda do certificado das produções, que devem ser livres de transgenes. Em diversas ocasiões, os agricultores necessitam entregar parte de sua produção às empresas detentoras das patentes dos transgenes;

$\checkmark$ Em longo prazo, a potencial resistência da PGM ou dos organismos alvo aos agroquímicos utilizados podem conduzir à perda da produtividade agrícola;

$\checkmark \mathrm{O}$ aumento da produtividade em curto prazo pode ocasionar uma expansão das monoculturas de PGMs, diminuindo a diversidade de variedades de cultivos e comprometendo a segurança alimentar;

$\checkmark$ Os potenciais impactos ambientais sobre as espécies não alvo conduzem ao desequilíbrio do ecossistema;

$\checkmark$ A coexistência entre os diversos sistemas de cultivo não é possível, em razão do desconhecimento acerca da segurança das barreiras criadas para evitar o fluxo gênico. $\mathrm{O}$ escape das sementes pode ocorrer durante o transporte, armazenagem e uso de maquinário comum na semeadura e colheita, enquanto que o pólen pode se disseminar pelo vento, animais e água, dependendo das condições ambientais locais;

$\checkmark$ A modificação do sistema de plantio no caso de cultivos transgênicos para convencionais ou orgânicos pode ser inviável caso haja a permanência das sementes no solo;

$\checkmark$ Mercados externos que não comercializam produtos transgênicos podem ser perdidos;

$\checkmark$ A participação da sociedade precisa ser garantida a fim de legitimar as tomadas de decisão, em razão dos interesses e valores envolvidos;

$\checkmark$ Os direitos do consumidor devem ser garantidos por meio da rotulagem;

$\checkmark$ Dadas as incertezas quanto aos impactos ambientais, sociais e econômicos advindos das PGMs, é fundamental adotar o princípio da precaução nas tomadas de decisão.

No caso dos agentes sociais que possuem opiniões moderadas, ou seja, que não sejam, a priori, contrários ou favoráveis à liberação de PGMs, há os seguintes embasamentos (DALE; CLARKE; FONTES, 2003; PESSÔA, 2007): 
Em razão de cada OGM e ambiente de liberação ser único em suas características, uma análise caso-a-caso deve ser realizada antes de sua liberação, geralmente por meio de análise de risco, sendo que alguns propõem o EIA como instrumento mais adequado para tanto;

$\checkmark$ Os impactos ambientais são incertos e é necessário adotar medidas preventivas, tais como: a rastreabilidade da PGM ao longo da cadeia produtiva; a segregação dos produtos derivados dos diversos sistemas de plantio desde a semeadura das sementes, colheita, armazenagem e transporte;

$\checkmark$ As opiniões dividem-se em torno da rotulagem;

$\checkmark$ A competitividade com mercados externos produtores de PGMs é um fator positivo para seu cultivo, desde que medidas de biossegurança sejam adotadas;

Mais estudos devem ser efetuados com relação à estabilidade do transgene, sua inserção no genoma receptor e expressão nos tecidos na planta; sobre o potencial de dispersão das sementes pelo vento, água e animais, a fim de se estabelecer barreiras e distâncias seguras aos demais sistemas de plantio e áreas especialmente protegidas; a respeito da possibilidade de impactos negativos sobre organismos não alvo importantes para o agroecossistema e demais ecossistemas adjascentes; sobre a permanência das sementes GMs, dos inseticidas produzidos pelos transgênicos resistentes a insetos e dos herbicidas utilizados para o cultivo de PGMs sobre o solo, dentre outros;

$\checkmark$ A liberação de PGMs em escala comercial deve ser gradual, iniciando-se após a condução de estudos em confinamento (laboratório e campo) sob as diversas condições edafoclimáticas;

$\checkmark$ O monitoramento durante e após o plantio de PGMs é indispensável para a detecção de impactos negativos ou positivos.

No entanto, apesar das diversas premissas e proposições identificadas no debate nacional e internacional sobre esta questão, não é possível simplificar o posicionamento dos diversos atores sociais envolvidos, já que muitos adotam uma miscelânea das opiniões acima apresentadas, dependendo de seu grau de informação, da formação acadêmica ou sua ausência, das experiências adquiridas e do sistema de valores e interesses envolvidos.

As argumentações apresentadas pelos diversos setores sociais que participam no debate sobre a transgenia, especialmente no tocante a sua aplicação agrícola se fundamentam em benefícios e riscos constatados ou esperados em estudos científicos ou observações in situ. Dentre alguns potenciais impactos esperados ou identificados podem-se citar:

- Impactos derivados do uso de herbicidas em PGMs tolerantes a agroquímicos: 
resistência ao agroquímico por parte das plantas invasoras, em função de escape gênico ou seleção natural. Em sistemas agrícolas fortemente dependentes de herbicidas para o manejo dos cultivos, tal ocorrência é bastante prejudicial tanto ao agricultor, que necessita da aplicação de doses progressivamente maiores do herbicida, quanto ao meio ambiente e à saúde humana, que passa a consumir alimentos com elevadas doses de agroquímicos (ASLAKSEN; MYHR, 2006). Algumas evidências a respeito destes impactos foram apontadas em alguns estudos citados a seguir.

Owen (1997, apud ERVIN et al., 2003) documentou a resistência ao glifosato em populações de Amaranthus rudis, no estado de Iowa (EUA), e Van Gessel (2001, apud ERVIN et al., 2003) reportou a resistência de Conysa canadensis também ao glifosato, no estado de Delaware (EUA).

De modo ao testar a hipótese de resistência de plantas invasoras ao glifosato, Puricelli e Tuesca (2004) realizaram experimentos em campo relativos à alteração em longo prazo das populações de plantas invasoras em três sistemas de plantio, quais sejam, rotação trigo/soja, monocultura de soja e rotação soja/milho, para variedades convencionais e geneticamente modificadas, no período de 1997 a 2001 em uma fazenda italiana. Os resultados apontaram o papel do uso repetitivo do herbicida sobre a dinâmica populacional das espécies invasoras e a constatação de resistência ao mesmo.

Resultados obtidos com o projeto Farm Scale Evaluation no Reino Unido, realizado sob diversas condições ecossistêmicas com monitoramento de quatro anos demonstraram efeitos sobre o número e a diversidade de espécies invasoras após os cultivos de PGMs, que se apresentaram reduzidos em função, provavelmente, da aplicação dos herbicidas e que permaneceram até a segunda estação após a remoção dos cultivos. A preocupação suscitada é em relação à disponibilidade de alimentos para insetos benéficos e pássaros que têm nas plantas invasoras sua fonte alimentar, e a consequente redução da diversidade faunística que atua como controle biológico (HENRY, 2006).

Nos EUA, estudos realizados de longo prazo demonstraram casos de resistência de plantas invasoras a herbicidas (HENRY, 2006).

Na Europa e nos EUA, testes de campo com batata-doce resistente a herbicidas foram realizados, a fim de modelar a dinâmica populacional de uma espécie invasora de importância mundial, Chenopodium álbum, reconhecida como importante fonte alimentar para pássaros como Alauda arvensis. O trabalho buscou a identificação de possíveis alterações sobre a população de C. album decorrentes das atividades de manejo adotadas em função da PGM e seu consequente efeito sobre a biodiversidade destes pássaros. A interrelação dos impactos 
identificados nas duas espécies, ou seja, a redução substantiva de C. album e, consequentemente, de A. arvensis foi inferida em função das práticas agrícolas utilizadas (neste caso, a quantidade e modo de aplicação do herbicida) (WATKINSON et al., 2000).

- Impactos de cultivos que produzem agrotóxicos:

Enquanto alguns estudos demonstraram que o número e diversidade de organismos não alvo não se alteraram com a introdução de PGMs produtoras de agrotóxicos, outros confirmaram a diminuição ou instabilidade das populações de predadores naturais expostos a estas condições (HENRY, 2006).

Estudo desenvolvido por Harwood et al. (2005) na Universidade de Kentucky (EUA) relatou os efeitos da exposição da endotoxina Bt (CrylAb) produzida por milho transgênico (híbrido N79-L3, evento Bt-11, da Syngenta) a herbívoros não alvo e sua transferência a artrópodes ao longo da cadeia alimentar. Foram identificadas quantidades elevadas da toxina nos insetos não alvo Chaectonema pulicaria (abelha), Popillia japonica (abelha) Diabrotica undecimpunctata howardi, assim como nos artrópodes de terceiro nível trófico pertencentes às ordens Coccinellidae, Arane e Nabidae, indicando a capacidade de transferência da toxina aos níveis tróficos mais elevados da cadeia alimentar.

Impactos de longo prazo sobre polinizadores podem ter consequências danosas, de acordo com Tappeser (1999), já que são essenciais para a produção de frutos indispensáveis à alimentação humana e dos demais animais. Neste sentido, a autora defende a precaução como principal precedente para qualquer tomada de decisões envolvendo OGMs e, para tanto, o desenvolvimento de uma base de conhecimento sólida.

Diversos casos confirmaram a ocorrência de resistência de pragas à toxina $\mathrm{Bt}$ e mesmo estudos laboratoriais inferiem sua ocorrência em longo prazo caso as PGMs sejam cultivadas em larga escala (HENRY, 2006). Este fato é motivo de preocupação tanto pelos defensores quanto opositores do uso desta tecnologia, podendo ocorrer a curto, médio ou longo prazo.

- $\quad$ Efeitos sobre a decomposição da matéria orgânica no solo:

Há diversos estudos que demonstraram efeitos danosos sobre organismos presentes no solo, quanto à decomposição da matéria orgânica e persistência dos agroquímicos após o cultivo de PGMs (HENRY, 2006; MYHR; TRAAVIK, 2002). Conhece-se a capacidade de adesão de toxinas produzidas por plantas Bt. Palm et al. (1996 apud GROOT; DICKE, 2002) demonstraram a presença de 25 a $30 \%$ das toxinas produzidas por folhas de algodão Bt no solo em 40 dias após a retirada das plantas.

- $\quad$ Fluxo gênico sobre espécies parentais selvagens: 
Para seus defensores, a biotecnologia é um método seguro, sendo um aperfeiçoamento do melhoramento convencional de plantas que possibilita a inserção de genes de interesse de forma precisa no genoma hospedeiro e, desta forma, os riscos de fluxo gênico são diminutos (HELGREN et al., 2000). Entretanto, diversas observações detectaram fluxo gênico para espécies selvagens aparentadas, sendo que alguns cientistas inferem que este fato pode se suceder quando o plantio da PGM ocorrer nas vizinhanças destas espécies, mas pouco se sabe a respeito do estabelecimento do transgene nestas populações. Myhr e Traavik (2001) e Henry (2006) inferem que a persistência das populações atingidas apenas se sucederá quando o transgene lhes conferir vantagem seletiva. O estudo de Zapiola et al (2008), realizado no estado de Oregon, EUA, que teve por objetivo avaliar o potencial de escape gênico da variedade transgênica de grama resistente ao glifosato Agrostis stolonifera, demonstrou a presença do transgene em $62 \%$ das plantas aparentadas locais e sua persistência mesmo após a erradicação da PGM. As avaliações se deram em uma área teste de 4500 ha em Jefferson County, no estado de Oregon, sendo 62 ha plantados com a PGM no ano de 2002, monitoradas neste ano e durante um período de três anos após o término do experimento.

Messéan et al. (2007) efetuaram estudos para canola em três regiões da França representativas das condições climáticas e de práticas agrícolas do país, sendo o cultivo de canola GM substituído por variedades convencionais, após três e oito anos de plantio. Como resultados, identificaram a presença de transgenes em $18 \%$ das sementes coletadas, ultrapassando o limite de 0,9\% estipulado pela União Européia.

- Resistência a antibióticos em animais, decorrentes de possível transferência do gene marcador de resistência presente em diversos tipos de PGMs:

Desde o desenvolvimento dos primeiros OGMs que carregam genes marcadores de seleção provenientes de bactérias por cientistas pioneiros como Berg et al. (1974 apud TAPPESER, 1999), diversas preocupações têm surgido em relação à possível transferência horizontal destes transgenes aos consumidores, podendo ocasionar-lhes resistência a estes antibióticos. No entanto, a premissa geralmente adotada é a de que as proteínas produzidas pelos OGMs são digeridas rapidamente no intestino dos consumidores ou biodegradadas no solo, impossibilitando a transferência genética horizontal e vertical. Desde os anos sessenta, as análises de risco têm adotado esta premissa, mas algumas provas surgiram contrariando-as e demonstrando sua ocorrência principalmente em microorganismos do solo (ECKELKAMP; JÄGER; TAPPESER, 1998 apud TAPPESER, 1999; KELLY; VESPERMANN; BOLTON, 2009). Até mesmo em condições laboratoriais a recombinação em bactérias pode ser observada (GEBHARD; SMALLA, 1998 apud TAPPESER, 1999). 
A transferência horizontal em insetos e outros invertebrados também é possível, com o DNA do OGM permanecendo instável por um longo período e podendo ser transmitido pela corrente sanguínea aos leucócitos e órgãos, como o fígado (TAPPESER, 1999).

- Quanto aos impactos sócio-econômicos, se tem:

Aumento da rentabilidade agrícola, com diminuição do uso de agrotóxicos e herbicidas, com benefícios econômicos ao produtor e ao consumidor, que pode ter acesso a alimentos com menor custo (HELGREN et al., 2000). No entanto, há algumas constestações neste sentido que apontam o crescimento das áreas de cultivo de PGMs movido pelas promessas do aumento da rentabilidade agrícola como uma ameaça à segurança alimentar, devido à diminuição da diversidade agrícola. Um exemplo concreto de tal impacto vem sendo verificado com a soja Roundup Ready na Argentina, cujo plantio se proliferou de tal maneira que atingiu, em 2007, 60\% das áreas cultivadas de todo o país ${ }^{2}$. Ao mesmo tempo em que se dava a "sojização" do país, houve uma grande diminuição das culturas de subsistência (arroz, trigo, girassol, lentilha) com o consequente aumento do preço dos produtos de consumo básico (ROBIN, 2008).

A manipulação genética de culturas agrícolas tem sido motivada pelo aumento de sua rentabilidade. Em sua maioria, seus produtos são elaborados e patenteados por empresas multinacionais, que os fornecem aos agricultores com a contrapartida do pagamento de royalties, impossibilitando o cultivo de sementes nas safras seguintes (HANDMARSH, 1990). Na atualidade, quatro empresas controlam praticamente toda a produção de sementes transgênicas no mundo: Monsanto, Novartis, Syngenta e Dupont. O pioneirismo neste ramo pode ser atribuído à Monsanto, que introduziu no mercado uma PGM resistente ao seu próprio herbicida, o glifosato. Segundo Pelaez e Schimidt (2000), o desenvolvimento de transgênicos pela empresa pode ser considerado uma estratégia para valorizar seu princípio ativo (glifosato) em um ambiente de competição e de regras ambientais mais rígidas em relação ao emprego de agroquímicos. Deste modo, a criação de um pacote tecnológico envolvendo o organismo transgênico e seu respectivo herbicida parece ser uma solução rentável para a garantia de mercados sob a fachada da "sustentabilidade ambiental".

- Melhoria da qualidade ambiental (solo, água, ar, biodiversidade, redução do uso de maquinários) promovida pela diminuição das aplicações de agroquímicos (CARPENTER; GIANESSE, 1999; HELGREN et al., 2000).

\footnotetext{
${ }^{2}$ Segundo a autora, enquanto em 1971 a plantação de soja, até então convencional, não ultrapassava 37 mil ha, passaram a 8,3 milhões em 2000, 9,8 milhões em 2001, 11,6 milhões em 2002 e 16 milhões de ha em 2007, com a introdução da soja transgênica.
} 
- Desenvolvimento de variedades mais nutritivas e com tolerância aos estresses ambientais, que dificilmente poderiam ser criadas por métodos convencionais, com objetivos de aumento de rentabilidade e da qualidade alimentar (BAJAJ; MOHANTY, 2005).

Dadas as incertezas sobre os potenciais riscos resultantes da utilização de OGMs, mecanismos que a regulam foram elaborados por organizações multilaterais, empregados para a movimentação transfronteiriça de OGMs e que têm servido de guias para a criação de sistemas regulatórios no âmbito das nações, de acordo com suas particularidades políticas. Dentre tais organizações encontram-se o Programa das Nações Unidas para o Meio Ambiente (PNUMA), a Organização Mundial de Saúde (OMS) e a FAO. No entanto, como o presente trabalho trata das implicações ambientais da liberação em escala comercial de PGMs, será abordado somente o guia elaborado pelo PNUMA.

\subsection{Tratados internacionais sobre o tema: Programa das Nações Unidas para o Meio Ambiente e o Protocolo de Cartagena sobre Biossegurança}

Na década de 90, o Ad Hoc Working Group on Biological Diversity do Programa das Nações Unidas para o Meio Ambiente elaborou estudos a fim de desenvolver metodologias legalmente embasadas para a avaliação dos riscos ambientais advindos da biotecnologia moderna. Dentre as demandas avistadas, houve a abertura e troca de informações para a formulação de mecanismos regulatórios multilaterais para a biotecnologia, fator reforçado pelas incertezas científicas quanto às suas consequências. $\mathrm{O}$ grupo também destacou a necessidade de os instrumentos legais multilaterais lidarem com os impactos éticos, socioeconômicos e de biossegurança, na regulação da técnica. Dadas as incertezas sobre os OGMs, o PNUMA recomendou a realização de uma Conferência das Nações Unidas sobre Meio Ambiente e Desenvolvimento que tratasse, dentre outros temas, da biossegurança dos OGMs, resultando na Convenção sobre Diversidade Biológica (CDB) (KORMOS e HUGHES, 2000).

Os artigos 8(a) e 19 da Convenção sobre Diversidade Biológica requeriam às Partes compactuantes a criação de um conjunto de normas visando a biossegurança de OGMs por meio de um Protocolo, a fim de se evitar possíveis consequências negativas de seu uso. Além disto, uma avaliação de impacto ambiental deveria ser aplicada para projetos que envolvessem o uso destes organismos. No intuito de efetuar os pressupostos da Convenção, uma Conferência das Partes da Convenção sobre Diversidade Biológica ocorreu na Indonésia em 1995, com o objetivo de elaborar um acordo para a normatização do movimento 
transfronteiriço de OGMs, tendo como pressupostos: o princípio da precaução, a necessidade de consentimento pré-informado do país destinatário em que ocorrerá a liberação e o respeito à soberania dos povos. Nesta Conferência, formaram-se as bases para o desenvolvimento do Protocolo de Cartagena sobre Biossegurança (KORMOS e HUGHES, 2000).

Em fevereiro de 1999, mais de 130 países reuniram-se em Cartagena, Colômbia, com intuito de negociar os movimentos transfronteiriços de OGMs, sua rotulagem e as consequências ambientais e socioeconômicas derivadas de seu uso. Neste sentido, o Grupo dos 77 (G77), formado por países desenvolvidos e algumas organizações não-governamentais, concordaram quanto à abordagem precaucionista em relação à biossegurança, a elaboração de Acordos de Informação Avançada para a movimentação internacional de OGMs e procedimentos de avaliação de riscos. A rotulagem e a realização de avaliações de impactos socioeconômicos paralelos à avaliação de biossegurança, sob responsabilidade do produtor, foram outras questões acordadas por algumas Partes. Algumas ONGs sugeriram também uma moratória de 5 anos na comercialização de OGMs até que se desenvolvessem procedimentos de avaliação de risco e biossegurança (KORMOS e HUGHES, 2000).

Enquanto isto, o denominado Grupo Miami, liderado pelos EUA, Canadá, Argentina, Chile, Austrália e Uruguai, ou seja, as maiores nações produtoras e exportadoras de OGMs buscaram o convencimento das Partes quanto à elaboração de normas de biossegurança e avaliações de risco de caráter voluntário, alegando que um sistema rígido impossibilitaria as atividades de P\&D (Pesquisa e Desenvolvimento) sobre biotecnologia, assim como a comercialização de OGMs. Deste modo, propuseram o uso de licenciamentos acordados para garantir o cumprimento voluntário sobre os procedimentos de gestão dos riscos e o relato dos dados necessários ao monitoramento dos OGMs. Também exigiram a exceção dos procedimentos de análise de risco aos OGMs considerados seguros, permanência das normas existentes na Organização Mundial de Comércio e declararam-se contrários à rotulagem, por razões de competitividade econômica. As pressões de ambas as partes, especialmente do Grupo Miami, que não se dispôs a aceitar a modificação de algumas de suas premissas, conduziram ao adiamento do Protocolo, cujas negociações foram retomadas em novembro de 1999, em Viena, sob fortes manifestações públicas exigindo a rotulagem dos produtos transgênicos, o aprimoramento técnico das análises de riscos, a avaliação das consequências do uso de OGMs à agricultura orgânica e a definição das responsabilidades sobre os danos sócio-ambientais.

Somente em 2000, as Partes se reuniram novamente em Montreal, a fim de deliberar sobre o Protocolo, sendo o documento final um balanceamento entre ambos os 
posicionamentos. Desta forma, tanto o preâmbulo quanto o artigo 10 do Protocolo discorrem sobre a adoção do princípio da precaução como premissa para a utilização dos OGMs:

\begin{abstract}
A ausência de certeza científica devida à insuficiência das informações e dos conhecimentos científicos relevantes sobre a dimensão dos efeitos adversos potenciais de um organismo vivo modificado na conservação e no uso sustentável da diversidade biológica da Parte importadora, levando também em conta os riscos para a saúde humana, não impedirá esta Parte, a fim de evitar ou minimizar estes efeitos adversos potenciais, de tomar uma decisão, conforme o caso, sobre a importação do organismo vivo modificado em questão [...].
\end{abstract}

(BRASIL, 2006)

Uma consideração favorável ao Grupo de Miami a respeito das regras da Organização Mundial de Comércio (OMC) encontra-se no preâmbulo do Protocolo, quando afirma que "o presente Protocolo não será interpretado no sentido de que modifique os direitos e obrigações de uma Parte em relação a quaisquer outros acordos internacionais em vigor" (BRASIL, 2006). No entanto, sendo o Protocolo um acordo internacional, a Parte que a ele recorra como, por exemplo, na questão da proibição de importação de um OGM com base no princípio da precaução, teria também respaldo legal para confrontar a Parte exportadora na OMC.

Dentre os OGMs destinados à regulação excetuam-se os fármacos. Deste modo, fazem parte do escopo regulatório os OGMs objetivados à liberação no meio ambiente e os produtos destinados à alimentação humana e dos demais animais, sendo necessária uma notificação completa (cujas informações solicitadas constam no Anexo I do referido Protocolo) no primeiro caso, com avaliação de risco a encargo do notificador e confirmação da parte importadora para com os procedimentos de Acordo Prévio Informado. Já no caso de produtos alimentícios, requerem-se informações a respeito de seu processo de aprovação no país de origem. Apenas na primeira movimentação transfronteiriça intencional de OGMs destinados à introdução deliberada no meio ambiente e ao uso direto como alimento humano e de outros animais ou ao beneficiamento, há a necessidade de Acordo Prévio Informado, a não ser que, por meio de Reunião das Partes, se declare que os mesmos não acarretarão efeitos adversos à saúde humana ou animal ou ainda ao uso sustentável da diversidade biológica.

As avaliações de risco devem ser conduzidas de forma cientificamente embasada, com intuito de garantir a segurança do OGM quanto à utilização sustentável da diversidade biológica e aos riscos para a saúde humana, sendo exigidas antes de sua primeira liberação ambiental e comercial, submetendo-o a um período de observação correspondente ao seu ciclo de vida ou tempo de geração, antes da tomada de decisão. Dentre as medidas de segurança em 
movimentos transfronteiriços intencionais, o país exportador deve providenciar que os OGMs destinados à alimentação ou beneficiamento sejam identificados como "podendo conter" OGMs e que não estejam destinados à liberação no meio ambiente, assim como um ponto de contato para informações. Aqueles destinados ao uso em contenção devem ser identificados como "organismos vivos modificados", especificando-se regras de segurança para sua manipulação, armazenamento, transporte e uso, assim como o ponto de contato para informações. Já os OGMs destinados à introdução intencional no meio ambiente devem ser identificados como "organismos vivos modificados", determinando-se sua identidade e traços/ou características relevantes, as regras para sua manipulação, armazenamento, transporte e uso, assim como o ponto de contato. O julgamento acerca da consideração dos impactos socioeconômicos derivados da importação de OGMs fica sob incumbência da parte importadora. As avaliações de risco devem ser realizadas caso-a-caso, de forma transparente e, salvaguardado o princípio da precaução, o parágrafo 4 do Anexo II preconiza que "a falta de conhecimentos científicos ou de consenso científico não será necessariamente interpretada como indicativo de um nível determinado de risco, uma ausência de risco ou a existência de um risco aceitável”. A análise de risco deve conter as seguintes etapas (BRASIL, 2006):

a) Identificação de qualquer característica genotípica ou fenotípica nova associada ao OGM que possa conter efeitos adversos sobre a biodiversidade, o meio receptor ou à saúde humana;

b) Probabilidade de tais efeitos se sucederem, considerando o nível e tipo de exposição;

c) Estimativa do risco geral com base na probabilidade e consequências dos efeitos adversos;

d) Recomendação sobre a aceitabilidade dos riscos e a identificação de estratégias para manejá-los;

e) Na existência de incertezas quanto ao nível dos riscos, poderão ser solicitadas maiores informações ou a implementação de estratégias de manejo e/ou monitoramento do OGM no meio receptor.

Quanto à participação pública nas tomadas de decisão, o Protocolo assegura que as partes envolvidas promovam a conscientização e educação do público por meio do acesso às informações, além de sua consulta durante o processo. No entanto, tais consultas devem ser definidas de acordo com as leis e os regulamentos dos países envolvidos, não as tornando obrigatórias. No tocante às movimentações transfronteiriças ilícitas, o país afetado poderá solicitar ao país de origem a retirada do OGM por meio de sua repatriação ou destruição, a ônus do mesmo.

Algumas considerações críticas a respeito da análise de risco proposta pelo Protocolo de Cartagena são discutidas por Henry (2006): 
- Identificação do perigo: não é recomendada uma técnica ou guia específico para tanto, considerando apenas que cabe ao analista identificar os efeitos adversos do novo genótipo e seu fenótipo associado à saúde e ao meio ambiente;

- Análise das probabilidades e consequências: não é proposto técnicas para a identificação e quantificação das probabilidades e consequências dos efeitos adversos potenciais. No entanto, recomenda que a análise das probabilidades deva se basear no tipo e nível de exposição do OGM no ambiente receptor, levando em conta sua localização, clima, características ecológicas, biodiversidade e centros de origem dos cultivares não transgênicos;

- Análise de incertezas: da mesma forma, não há recomendações a respeito de técnicas para a análise das incertezas, focando apenas na necessidade de obtenção de informações e no monitoramento. A significância do risco é colocada em termos de sua aceitabilidade e possibilidade de manejo dos perigos;

- Monitoramento e revisão: não são apresentadas técnicas de monitoramento, mas considera-se uma ferramenta necessária para a análise das incertezas. Recomenda-se, entretanto, que as avaliações considerem a especificidade, sensibilidade e confiabilidade nos métodos utilizados para detectar e identificar o OGM;

- Efeitos de longo prazo e cumulativos: o protocolo não os considera e não discute a duração e escala de liberação dos OGMs.

Dentre os países que adotaram o Protocolo de Cartagena, encontram-se os Estados Unidos da América, a União Européia, o Canadá, Austrália, Nova Zelândia e Brasil. Por serem nações e comunidades que possuem grande influência sobre as relações comerciais internacionais, serão abordados com mais detalhes a regulação de OGMs nos EUA e na UE, com os demais países sendo revisados sucintamente.

\subsection{Sistemas regulatórios sobre OGMs em alguns países e comunidades de referência.}

\subsubsection{Estados Unidos da América}

Os EUA são os principais produtores mundiais de variedades GMs e concentram as principais empresas de biotecnologia do mundo. Das cerca de 50 variedades para cultivo utilizadas pelos agricultores, destacam-se: soja ( $91 \%$ do total de soja cultivada no país), algodão ( $88 \%$ do cultivo de algodão), milho ( $85 \%$ do cultivo total de milho), canola, abobrinha, mamão, arroz, chicória, tomate, beterraba e linhaça (NATIONAL AGRICULTURAL STATISTICS SERVICE, 2009). A regulação dos cultivos geneticamente 
modificados no país, que recebe tratamento diferenciado em relação aos organismos desenvolvidos por outras técnicas de melhoramento gnético, se baseia no Princípio de Equivalência Substancial entre o OGM e sua contraparte convencional. Caso seja considerado equivalente, os critérios para o plantio e comercialização do OGM passam a ser idênticos àqueles de sua contraparte convencional (THE CENTER FOR FOOD SAFETY, 2007; KINGSBURY, 1988; KORMOS; HUGES, 2000).

A primeira agência governamental a elaborar normas para a regulação da biotecnologia nos Estados Unidos da América foi o National Institute of Health (NIH), a partir das deliberações provenientes da Conferência Internacional de Asilomar, realizada em 1976 com o objetivo de delinear medidas para a prevenção de acidentes laboratoriais envolvendo o escape de organismos geneticamente modificados pela técnica do DNA recombinate. Até 1978, a liberação de OGMs no meio ambiente era proibida pelo NIH, o qual passou, a partir deste momento, a afrouxar as normas para sua permissão (KINGSBURY, 1988).

Em 1986, uma instrução normativa criou o Coordinated Framework for Regulation of Biotechnology, conhecido por Framework, composto pela Environmental Protection Agency (EPA), o United States Department of Agriculture (USDA), o Food and Drug Administration (FDA) e o Occupational Safety and Health (OSHA), organizações responsáveis pela regulação de OGMs (THE CENTER FOR FOOD SAFETY, 2007).

As Agências mencionadas, ou seja, USDA, EPA e FDA possuem papéis diversos concernentes à regulação. O USDA busca assegurar que o organismo não se comporte como uma planta invasora quando utilizada na agricultura. A EPA responsabiliza-se em fixar limites toleráveis dos pesticidas para a garantia da saúde ambiental e animal e a FDA busca assegurar a proteção da saúde humana e dos demais animais que consumam OGMs, coordenadamente com a EPA (THE CENTER FOR FOOD SAFETY, 2007; KINGSBURY, 1988; KORMOS; HUGHES, 2000).

A partir de 1987, os requisitos para a aprovação de ensaios de campo com OGMs tornaram-se menos complexos, passando para um processo de notificação, que se estabeleceu a partir de 1993, sendo mais simplificado a partir de 1997. O Animal and Plant Health Inspection Service (APHIS) do Departamento de Agricultura dos EUA é o órgão responsável pela proteção da agricultura contra plantas invasoras e doenças, assim como pela movimentação, importação e testes em campo de OGMs destinados ao cultivo, e é regido pelo Federal Plant Pest Act (FPPA). De acordo com este ato, um OGM somente pode ser regulado caso haja risco de se tornar uma praga agrícola (JESUS et al., 2006). 
No momento em que um OGM se enquadre nos requisitos do FPPA, o APHIS estabelece critérios para determinar a necessidade de sua regulação por meio de licenciamento para testes em campo, movimentação e importação, exigindo estudo de impacto ambiental no caso de sua liberação no meio ambiente, de acordo com as normas da EPA. Desta forma, o órgão que decide pela necessidade de ensaios de campo para OGMs é o Departamento de Agricultura estadunidense e não a Agencia de Proteção Ambiental. (JESUS et al., 2006; THE CENTER FOR FOOD SAFETY, 2007):

A partir de 1997, quando se estabeleceu os procedimentos para notificação, milhares de OGMs foram liberados para plantio e comercialização sem licenciamento, perfazendo um total de $97 \%$ das solicitações. Dentre as plantas atualmente reguladas via notificação encontram-se o milho, algodão, tomate, soja, tabaco e tomate. Além de cumprir os critérios anteriormente expostos, as notificações são concedidas desde que seja cumprida uma lista de padrões de performance, tais como: a contenção dos organismos durante o transporte; a possibilidade de sua identificação durante todas as etapas de introdução; a separação com as demais variedades não GMs e a eliminação dos resíduos após o término do projeto. Os métodos para o alcance destes padrões não são especificados pela APHIS, assim como a vigilância de seu cumprimento, que pode ser feita ocasionalmente (KORMOS; HUGHES, 2000). Tal modificação no marco regulatório dos EUAs se deu por uma política de incetivo à biotecnologia no país (JESUS et al., 2006).

Em alguns casos quando, a título de exemplificação, o material exógeno da planta a ser modificada não inclui um gene completo, a APHIS pode conceder ao requerente uma licença de cortesia, tanto para projetos de testes em campo quanto de movimentação e importação, por meio da qual se procede a mecanismos simplificados em relação ao licenciamento e a notificação (KORMOS; HUGHES, 2000).

A APHIS também possibilita ao produtor a submissão de petições de desregulamentação para produtos regulados, desde que comprovada sua inocuidade ao meio ambiente. A Agência pode também desregulamentar OGMs de forma unilateral, sem a solicitação por parte dos produtores, baseando-se em sua similaridade com outra variedade desregulamentada. Dentre os OGMs desregulamentados pela APHIS estão a abóbora e o algodão, ambos possuidores de variedades selvagens aparentadas no país (KORMOS; HUGHES, 2000).

A Agência de Proteção Ambiental regulamenta os OGMs por meio do Federal Insecticide, Fungicide and Rodenticide Act (FIFRA), o qual requer o registro na Agência de qualquer pesticida antes de sua distribuição, venda e utilização; pelo Federal Food, Drug and 
Cosmetic Act (FFDCA), que requer a determinação de níveis de tolerância para substâncias nocivas nos produtos agrícolas, e pelo Toxic Substances Control Act (TSCA), que atribui à EPA a regulamentação sobre a produção, venda, transporte interestadual e disposição final de novas substâncias químicas potencialmente danosas ao meio ambiente e à saúde (KORMOS; HUGHES, 2000).

Como requisito para o registro de pesticidas, dentre os quais se encontram as variedades transgênicas produtoras de pesticidas, o proponente necessita apresentar evidências que comprovem sua inocuidade ao meio ambiente. Neste sentido, requer-se a realização de testes em campo, com a solicitação de uma Licença de Uso Experimental quando de sua liberação no meio ambiente sem barreiras de contenção. Necessita-se, para tanto, fornecer dados sobre o organismo doador, receptor e vetor, a habilidade para cruzamentos e suas formas de detecção. Experimentos em áreas menores do que 10 acres podem ser dispensados da licença, com exceção de projetos relacionados a microorganismos, em razão de seu alto potencial de disseminação. Os requerentes devem fornecer informações sobre a extensão e padrões de uso do pesticida, além de seu potencial de exposição ao ser humano e ao meio ambiente. A solicitação da licença é publicada pela EPA no Registro Federal visando à informação pública (KORMOS; HUGHES, 2000).

A concessão da licença é dada automaticamente para produtos similares substancialmente a outros já aprovados e produtos com novos ingredientes ativos, sendo indispensável, em todos os casos, a garantia de sua inocuidade ao meio ambiente (KORMOS; HUGHES, 2000).

Em novembro de 1994, a EPA publicou uma norma que dispensa a regulação aos pesticidas que não ofereçam elevados riscos aos organismos não alvo. Como critério inicial para a dispensa da regulação, a Agência avalia o grau de novidade do pesticida em relação à planta receptora e ao meio ambiente, como são os casos de pesticidas derivados de plantas aparentadas evolutivamente. Críticos aos critérios de dispensa argumentam sobre a necessidade de considerar a quantidade de pesticidas produzidos pela planta transformada, a qual poderia ser maior em plantas GMs devido a mudanças genéticas quantitativas (KORMOS; HUGHES, 2000).

O papel da FDA é o de prevenir a comercialização de alimentos adulterados, ou seja, que contenham produtos prejudiciais à saúde humana, incluindo aditivos e pesticidas não aprovados, além de possuir autoridade para a remoção de alimentos adulterados no mercado e a imposição de sanções criminais a produtores que descumprirem a legislação. A Agência realiza a avaliação pré-comercial dos alimentos contendo aditivos, ao menos que estes se 
enquadrem na cláusula "Generally Recognized as Safe" (GRAS) no caso de alimentos que não apresentem novas substâncias, sendo considerados inócuos à saúde. Apesar das controvérsias a respeito do grau de novidade dos produtos GMs, considerados aditivos por alguns analistas, diversos alimentos GMs ou contendo OGMs são enquadrados como GRAS, sob a justificativa da equivalência substancial. Sendo responsável também por determinar a rotulagem dos alimentos, a Agência não a tem requerido para alimentos contendo OGMs, já que não são considerados diferentes dos convencionais (MOORE, 2000; KORMOS; HUGHES, 2000; PELLETIER, 2006).

Apesar das preocupações por parte dos consumidores, a FDA não tem requerido testes pré-comerciais para alimentos derivados da engenharia genética. Com esta dispensa, a modificação no status do produto visando sua regulação como aditivo é voluntária ou se dá quando a Agência e consumidores detectem efeitos negativos durante sua comercialização (MOORE, 2000). O único OGM submetido a tal regulação foi o Flavor Savor Tomato, da Calgene (PELLETIER, 2006).

No processo regulatório do país, a participação pública limita-se às indagações e comentários durante períodos definidos na avaliação de risco. Neste sentido, estudo realizado pelo National Research Council sobre as ações da FDA mostra a falta de transparência durante a definição dos critérios de análise do risco, em função, dentre outros aspectos, das reiteradas aceitações dos pedidos de confidencialidade da informação para a proteção das patentes comerciais das empresas (NATIONAL RESEARCH COUNCIL, 2002).

Evidências apontam a interferência direta da bioindústria no direcionamento das políticas de OGMs nos EUA, visando um afrouxamento no controle das agências reguladoras para uma rápida e eficaz comercialização interna e o aumento da competitividade e controle dos mercados internacionais. Neste sentido, Pelletier (2006), aponta para os primórdios da constituição do Coordinated Framework durante o governo Reagan, em 1984, cujas interferências do Conselho de Competitividade, solicitado a solucionar os conflitos levantados pelas agências a respeito da abordagem regulatória dos OGMs, tiveram papel determinante sobre a mesma, por meio do documento Principles for Regulatory Review of Biotechnology, a partir do qual se determinou a regulação focada no produto ao invés do processo, a redução das barreiras regulatórias, nos limites de cada agência, buscando acomodar os avanços tecnológicos e fazendo uso de padrões de performance (níveis de tolerância) em lugar de controles rígidos. As legislações finais basearam-se no pressuposto de que a liberação dos produtos advindos da biotecnologia possa se dar sob a "evidência de que os riscos derivados de sua introdução sejam razoáveis”, em uma análise de custo-benefício. 
Quanto à transparência do processo de definição das políticas regulatórias para OGMs, o Administrative Procedures Act de 1946, obriga as agências reguladoras a publicar suas propostas de regulamentação no Registro Federal, propiciando a consulta pública, o que não se sucede. O mesmo se dá para com as petições de desregulamentação via GRAS, realizadas por meio de consultas privadas e voluntárias do produtor com a Agência sem notificação prévia ao público. A influência da bioindústria sobre a definição das políticas a respeito dos OGMs é relatada por Pelaez (2004), especificamente sob o lobby da Monsanto. Um documento de 13 de outubro de 1986, elaborado pela empresa e parcialmente publicado no jornal The New York Times apresentou o seguinte, como solução aos entraves políticos para a liberação de seus produtos avindos de OGMs, dentre os quais se destaca a soja resistente ao herbicida glifosato Roundup:

[..] o engajamento de representantes públicos nomeados para as agências reguladoras (FDA e EPA); e a busca de apoio político nas plataformas eleitorais, tanto no Partido Republicano quanto no Democrata, à Presidência da República de 1998 [...] uma participação ativa junto à comunidade, de forma a atrair o interesse público e obter o apoio de grupos de consumidores e de ambientalistas à biotecnologia, engajando-os inclusive como consultores da empresa.

(EICHENWALD, 2001 apud PELAEZ; SBICCA, sem data, p. 15)

A atribuição de funções sobre a regulação de OGMs por meio de Agências já consolidadas e dotadas de confiabilidade pública, em detrimento da constituição de órgãos específicos para tanto é explanada como uma estratégia do governo norteamericano para a aceitação pública dos OGMs, visando o atendimento dos interesses comerciais da bioindústria (GUEHLSTORF, 2004 apud GUEHLSTORF; HALLSTROM, 2005).

Segundo Kimsky (1999) apud Guehlstorf e Hallstrom (2005) o programa governamental Cooperative Research and Development Agreement (CRADA), desenvolvido pelo governo federal para se estabelecer uma parceria entre laboratórios federais e as indústrias, é indicativo da influência destas sobre as políticas governamentais concernentes às tecnologias. O objetivo do programa é a promoção da flexibilidade na estruturação de projetos, o direito à propriedade intelectual e a proteção da confidencialidade dos produtos desenvolvidos pelas bioindústrias.

\subsubsection{União Européia}


Nas duas últimas décadas, a União Européia vem estabelecendo princípios e normas comuns para reger o processo de regulação dos OGMs em seus países-membros. Possuindo uma legislação ambiental ancorada no Princípio da Precaução, as diversas diretivas concernentes ao tema definem um processo de avaliação cauteloso, com critérios rígidos e menos tendenciosos aos interesses da bioindústria do que nos EUA. O objetivo é a garantia de segurança dos produtos à saúde humana e animal e ao meio ambiente, por meio de normas específicas para sua liberação no meio ambiente e comercialização (SAEGLITZ; BARTSCH, 2003).

O regime regulatório da UE concebe as variedades transgênicas como originais e distintas das produzidas pelos métodos convencionais, levando à necessidade de sua avaliação de forma separada. Diversas diretivas dispõem sobre o tema: Diretiva 258/97/EEC (Novel Foods), Regulação EC/1139/98, sobre a rotulagem e a rastreabilidade; Regulação 1829/2003, com normas para a avaliação de risco nas fases pré e pós-comerciais (com exigência de monitoramento) e a Diretiva 2001/18/EC, que trata da liberação experimental em campo. A avaliação de risco de OGMs abrange a identificação das características que possam ocasionar efeitos adversos e a avaliação de suas consequências potenciais com a probabilidade de ocorrência e a estimativa do risco para cada característica do OGM. Devido às limitações dos parâmetros e espécies disponibilizadas para exames laboratoriais de biossegurança e o reconhecimento sobre a complexidade das relações intra e interespecíficas nos ecossistemas, considera-se a necessidade de monitoramento em campo caso-a-caso após a permissão para o plantio, com intuito de se detectar possíveis efeitos adversos (SAEGLITZ; BARTSCH, 2003).

A avaliação de risco deve comprovar a ausência de efeitos adversos do OGM, a garantia de informações aos consumidores e uma qualidade nutricional adequada (VARZAKAS et al., 2007). A avaliação de risco ambiental deve incluir os seguintes prérequisitos: impactos do fluxo gênico vertical fora e dentro da área de plantio e suas consequências (inclusive sócio-econômicas); impactos da transferência genética horizontal sobre os microorganismos; impactos sobre organismos não alvo e impactos das variedades contendo genes inseticidas sobre a biodiversidade agrícola.

A respeito da normatização de alimentos derivados de OGMs tanto para consumo humano quanto aos demais animais, a Regulação 1829/2003 estipula a necessidade de avaliações de segurança pelo proponente, além de uma avaliação independente pela European Food Safety Authority (EFSA). Por esta regulação, o proponente deve garantir que o produto esteja de acordo com os requisitos de rastreabilidade e rotulagem (caso contenha mais de $0,5 \%$ de produto geneticamente modificado) e realizar o monitoramento pós-comercial, a fim 
de demonstrar o cumprimento das normas estabelecidas (VARZAKAS et al., 2007).

A regulamentação a respeito da liberação dos OGMs no meio ambiente e sua comercialização se faz presente na Diretiva 2001/18 EC (que revoga a Diretiva 90/220 CEE), tendo por objetivo a proteção da saúde humana e do meio ambiente e a necessidade de análise dos riscos para a tomada de decisões, baseada no princípio da precaução e no respeito aos aspectos éticos dos países-membros. Determina que a avaliação de risco se realize caso-acaso, considerando os possíveis impactos cumulativos e em longo prazo provenientes da interação entre OGMs e com outros organismos não modificados, o que torna $o$ monitoramento pós-comercial obrigatório. A liberação ambiental é realizada em etapas, com o confinamento sendo progressivamente reduzido, à medida que a segurança é demonstrada nas etapas precedentes. Os procedimentos para a autorização consistem na notificação da autoridade competente do estado destinado à liberação, por meio da apresentação de uma avaliação completa dos riscos ambientais, das medidas de segurança em casos emergenciais e de informações sobre a embalagem e rotulagem do produto.

Com o intuito de adotar uma abordagem precaucionista, a avaliação de risco deve ter por princípios: a análise comparativa do OGM com sua contraparte convencional; ser transparente e assentada em bases científicas atualizadas; realizada caso-a-caso e passível de revisão. Dentre as informações necessárias, devem constar as características do organismo doador, vetor, receptor e das espécies ou variedades relacionadas, das alterações genéticas, da liberação ou utilização prevista e sua escala, além do ambiente receptor e suas interações. A avaliação deve apresentar as seguintes etapas (EUROPEAN AND PARLAMENT COUNCIL, 2001):

1) Identificação das características possíveis de induzirem efeitos adversos, por meio da comparação com contrapartes convencionais sob as mesmas condições ambientais. Nesta etapa, devem-se considerar os possíveis efeitos: reações alérgicas e tóxicas ao ser humano, demais animais e plantas; sobre a dinâmica das populações do meio receptor; alterações na vulnerabilidade a agentes patogênicos; resistências a antibióticos; alterações dos ciclos biogeoquímicos; disseminação e transmissão de material genético; instabilidade genotípica e fenotípica e modificações das práticas agrícolas;

2) Avaliação das potenciais consequências, que dependem do local e forma da liberação prevista;

3) Avaliação da probabilidade de ocorrência dos efeitos adversos, dependentes também da forma e local da liberação prevista;

4) Estimativa do risco inerente a cada característica conhecida do OGM como 
potencialmente danosa, por meio da combinação entre a probabilidade de ocorrência com sua magnitude;

5) Estratégia de gestão dos riscos.

Além da avaliação de riscos, são solicitadas informações a respeito do OGM, do local de liberação e as possíveis interações com seus elementos bióticos e abióticos, além das técnicas de monitoramento e tratamento dos resíduos produzidos e do plano de emergência previsto para casos de disseminação indesejada.

O processo para a utilização comercial de um OGM no meio ambiente consiste em uma notificação inicial ao país-membro de destino. A autoridade competente receptora da notificação envia o resumo do dossier elaborado pelo requerente à Comissão Européia, a qual o transmite aos demais países-membros, que podem se pronunciar em um período de 60 dias. Caso objeções justificadas não sejam realizadas findo este prazo, a Comissão emite parecer favorável à liberação. No caso de uma autoridade competente considerar que tenha adquirido experiência quanto à liberação de determinados OGMs em certos ecossistemas e que os mesmos preencham os critérios presentes no Anexo V da Diretiva, é facultada a solicitação de uma notificação diferenciada. As notificações são suscetíveis a alterações advindas de possíveis efeitos deletérios imprevistos após a liberação e das novas informações adquiridas sobre o organismo em questão e vigora por um período de 10 anos. Depois de concedida a autorização, os países-membros não podem proibir, restringir ou impedir a liberação do OGM em seu território, salvo se houver justificativas que atestem sua periculosidade, por meio de uma cláusula de salvaguarda. Com posse destas informações, o estado-membro em questão comunica a Comissão, que encaminha a solicitação ao Comitê formado por representantes dos países-membros e a decisão se dá em votação majoritária. Não havendo objeções justificadas à proposta de liberação, a autoridade competente emite um parecer favorável (EUROPEAN AND PARLAMENT COUNCIL, 2001).

No caso de rejeição da proposta, o Comitê submete a decisão ao Conselho Europeu, o qual pode decidir a favor da autorização por meio de votação majoritária ou pela rejeição, em decisão unânime. Passados três meses da consulta ao Conselho e não havendo qualquer manifestação de sua parte, a decisão é tomada pela Comissão Européia. No tocante à participação pública no processo de tomada de decisões, a Diretiva a faculta aos paísesmembros (EUROPEAN AND PARLAMENT COUNCIL, 2001).

Apesar da permissão legal para a comercialização de OGMs, há poucas variedades sendo comercializadas na UE, fato atribuído aos altos custos das análises de risco e monitoramento, assim como pela oposição pública. Desta forma, poucas solicitações para o 
cultivo de OGMs foram realizadas, com apenas a variedade de milho Bt 117 aprovada e cultivada na Espanha. Desde 1997, as preocupações da sociedade, principalmente por parte dos consumidores e grupos ambientalistas, têm influenciado as decisões políticas de diversos países-membros, conduzindo alguns (França, Itália, Dinamarca, Luxemburgo, Áustria e Grécia) à decisão sobre a moratória da produção e comercialização de OGMs em seu território, por meio do uso da cláusula de salvaguarda presente na Diretiva 2001/18/EC (SAEGLITZ; BARTSCH, 2003).

\subsubsection{Canadá}

Assim como nos EUA, o Canadá baseia as análises de risco ambiental e à saúde humana sob o prisma da racionalidade científica como método de aquisição de um conhecimento absoluto, legítimo e neutro, e do Princípio da Equivalência Substancial. Na década de 1990, o estreitamento dos laços comerciais entre ambos os países, com o Canadá exportando a maior parte de sua produção agrícola aos EUA, levou o país a desenvolver políticas favoráveis à comercialização de plantas e alimentos processados contendo material GM, sendo a rotulagem obrigatória apenas se comprovadas diferenças composicionais e de segurança destes em relação às suas contrapartes convencionais. A notificação de produtos contendo ou sendo GMs é mandatária no Canadá anteriormente à sua comercialização, permitindo aos órgãos de controle a decisão sobre a condução de avaliações de risco aos proponentes. Historicamente, entretanto, a exigência destas avaliações tem se mostrado episódica e reativa, devido à política não intervencionista do governo em questões de mercado (MOORE, 2000).

No país, o conceito de OGM abrange qualquer cultivo que apresente novas características, cujo desenvolvimento seja obtido por meio de engenharia genética ou melhoramento convencional, uma situação exclusiva do Canadá. Nos EUAs e na UE, por sua vez os organismos obtidos pela engenharia genética são objetos de regulações específicas (JESUS et al., 2006).

O processo regulatório de plantas e alimentos GMs envolve as agências governamentais Health Canada (HC), Canadian Food Inspection Agency (CFIA) e Environmental Canada (EC). Tais agências possuem responsabilidades próprias, mas que se sobrepõem por vezes, como são os casos do Health Canada e a CFIA no tocante às políticas de rotulagem. (CANADIAN BIOTECHNOLOGY ADVISORY COMMMITTEE, 2002). 
A Agência Canadense de Inspeção de Alimentos (CFIA) exerce função regulamentadora sobre a importação, liberação no meio ambiente, registro das variedades e cultivo para alimentação de animais de plantas com novas características, sendo a principal agência responsável pela regulamentação de OGMs. O processo regulatório envolve diversas fases: inicialmente, sob normatização e monitoramento da CFIA, realiza-se a avaliação das plantas em pesquisa de campo em pequena escala, sob condições de isolamento reprodutivo que evitem o contato com outras plantas no ambiente. Tais pesquisas de campo sob contenção são realizadas durante anos, a fim de se coletar dados agronômicos sendo que, caso os OGMs sejam promissores comercialmente, são sujeitos a avaliações ambientais e de segurança à saúde. As análises de risco ecológico são realizadas caso-a-caso, examinando-se os processos biológicos envolvidos e os impactos ambientais sobre a agricultura e diversidade biológica em relação a sua contraparte convencional, objetivando-se a detecção de possíveis modificações fisiológicas e ecológicas decorridas da modificação genética. A determinação da aceitabilidade e manejo dos riscos é feita pela Agência. O processo de avaliação de risco de alimentos GMs à saúde animal provenientes do Canadá ou importados é realizado mediante a mesma abordagem, ou seja, caso-a-caso, sendo as características nutricionais, composicionais e toxicológicas comparadas à contraparte convencional (CANADIAN BIOTECHNOLOGY ADVISORY COMMMITTEE, 2002).

A função do HC é avaliar a segurança dos alimentos para o consumo humano, incluindo alimentos GMs. As análises de risco baseiam-se também no Princípio da Equivalência Substancial, sob critérios composicionais, toxicológicos, nutricionais, de potencial alergênico e grau de exposição diário na dieta dos diversos grupos populacionais. As normas e informações exigidas constam nos Guidelines for the Safety Assessment of Novel Foods e as aprovações são publicadas de forma sumarizada nos sítios eletrônicos da CFIA e HC (CANADIAN BIOTECHNOLOGY ADVISORY COMMMITTEE, 2002).

De acordo com o Environmental Protection Act, o Environmental Canada avalia as análises de riscos de OGMs, em relação a seu grau de toxicidade ao meio ambiente. As avaliações devem abranger todas as fases do ciclo de vida do produto, desde sua manufatura à disposição final (CANADIAN BIOTECHNOLOGY ADVISORY COMMMITTEE, 2002).

\subsubsection{Austrália e Nova Zelândia}

A regulação dos OGMs na Austrália é de responsabilidade do Gene Regulator, órgão estatutário que se reporta diretamente ao Parlamento Australiano, tendo o Gene Technology 
Act 2000 e Gene Technology Regulations 20001 como legislações principais. O processo regulatório é implementado pelo Gene Technology Ministerial Council (GTMC), com representantes de todas as jurisdições da Austrália. Três comitês aconselham o Regulador em matéria de OGMs: Gene Technology Technical Advisory Committee, (GTTAC) Gene Technology Ettics Committee (GTEC) e o Gene Technology Community Consultative Committee (GTCCC) (OFFICE OF THE GENE TECHNOLOGY REGULATOR, 2005).

O Gene Technology Act 2000 tem por objetivo proteger a saúde e o meio ambiente frente aos possíveis riscos derivados de OGMs, identificando-os e manejando-os. O país adota uma política favorável ao desenvolvimento da biotecnologia, adotando uma avaliação de risco ambiental e à saúde pouco restritivas, excluindo as implicações sócio-econômicas do uso de OGMs. Neste sentido, críticas são feitas ao sistema regulatório da Austrália quanto ao atendimento do princípio da precaução preconizada nesta legislação (COCKLIN; DIBDEN; GIBBS, 2008).

Enquanto que o Gene Regulator possui a atribuição de tomar decisões sobre a liberação de OGMs, os estados têm poder para impedi-la em suas jurisdições, sendo que alguns apresentam posicionamentos mais restritivos em relação à comercialização de OGMs, como os estados de Victoria e Tasmania. Ambos os estados possuem uma política favorável à biotecnologia agrícola, mas implementaram moratórias aos OGMs entre os anos de 2001 e 2003 em Tasmânia e entre 2004 e 2008 em Victoria, visando principalmente a proteção de mercados. No entanto, mesmo adotando a política de promoção da biotecnologia na atualidade, permanecem como estados que se destacam quanto a uma maior abertura para o debate em torno desta questão, em contraposição ao governo central (COCKLIN; DIBDEN; GIBBS, 2008).

A tomada de decisões a respeito de OGMs pelos reguladores envolve um processo de análise de risco caso-a-caso, cientificamente embasada, incluindo os seguintes procedimentos: (OFFICE OF THE GENE TECHNOLOGY REGULATOR, 2005):

Contexto do risco: compreende o escopo da $\mathrm{AR}$, a natureza da modificação genética e seus potenciais riscos à saúde e ao meio ambiente, tendo por base a comparação do OGM com sua contraparte convencional e seus efeitos sobre o ambiente específico da liberação;

Identificação dos danos potenciais e suas origens, assim como os caminhos para sua concretização e possibilidade de ocorrência. A significância do impacto envolve fatores como seu grau de severidade, escalas geográfica e temporal de alcance, a interação com outros impactos e grau reversibilidade; 
$\checkmark$ Critérios para a AR: avaliações prévias, o potencial de o OGM ser prejudicial à saúde humana e outros organismos, além dos ecossistemas, transferência de material genético, dispersão e persistência do OGM no meio ambiente, potencial de vantagens seletivas sobre outros organismos, potencial de toxicidade, alergenicidade ou patogenicidade a outros organismos, dentre outros;

Manejo do risco: envolve o julgamento a respeito dos riscos que requerem uma gestão, assim como a escolha e aplicação das medidas de tratamento, que dependem das incertezas existentes. O processo de gestão visa tanto a prevenção quanto a mitigação dos riscos, em uma abordagem passo-a-passo que se inicia com a liberação sob contenção e comercialização em pequena escala, a fim de se avaliar os danos e formas de mitigação, para uma liberação e comercialização progressivas. Os resultados podem ser utilizados para a AR de variedades semelhantes. O monitoramento pós-comercial é exigido;

$\checkmark$ Comunicação do risco: mecanismo com respaldo legal com intuito de garantir a claridade, transparência e prestação de contas do processo decisório, além de garantir a participação pública. Os agentes do processo incluem especialistas, autoridades e público alvo. O Regulador deve possibilitar o acesso às informações durante todas as etapas do licenciamento (incluindo o monitoramento) e incorporar aspectos éticos e sociais levantados pelo GTEC e o GTCCC.

Na Nova Zelândia, desde 1998 o Hazardous Substances and New Organisms (HSNO) Act determina que novos organismos, dentre os quais se incluiem os GMs, são de responsabilidade regulatória do Environmental Risk Management Authority (ERMA NZ), uma agência independente composta por oito membros eleitos pelo Ministro do Meio Ambiente. Tal órgão tem o papel específico de tomar decisões no tocante à importação, desenvolvimento, testes de campo sob contenção e liberação ambiental de novos organismos. Além do HSNO o Biosecurity Act de 1993 se constitui em outra legislação responsável pela regulação de OGMs no país. Os protocolos de biossegurança do ERMA são considerados um dos mais criteriosos do mundo e inclui tanto OGMs quanto espécies exóticas (BARRAT; MOEED; MALONE, 2006).

A NZ adota uma análise de risco caso-a-caso para as solicitações de uso de novos organismos, de modo a considerar suas especificidades. Pesquisas com OGMs são realizadas no país desde a década de 1970 e desde 2003 vem sendo estudados seus efeitos ambientais em testes de campo sob contenção. O país adota uma avaliação prévia que inclui a magnitude, probabilidade e distribuição dos riscos, custos e benefícios ambientais e sócio-econômicos resultantes da liberação de um OGM tanto para as indústrias promotoras quanto para a nação 
em geral. Para tanto, os potenciais impactos diretos e indiretos são avaliados. Durante o processo decisório, abre-se espaço para audiências públicas e consultas a painéis de especialistas, que avaliam os resultados das análises de risco realizadas pelo proponente (MINISTRY FOR THE ENVIRONMENT, 2007).

Não há protocolos de biossegurança específicos para plantas transgências na NZ, utilizando-se os mesmos delineados para agentes de controle biológico e espécies exóticas, com alguns requisitos variando entre os três grupos, como apresentado na Tabela 1 (BARRAT; MOEED; MALONE, 2006).

Tabela 1 - Informações de Biossegurança requeridas pelo RMA ZN para agentes de controle biológico, novas plantas e plantas transgências.

\begin{tabular}{|c|c|c|c|}
\hline Critérios de Biossegurança & $\begin{array}{l}\text { Novas } \\
\text { espécies }\end{array}$ & $\begin{array}{c}\text { Novos } \\
\text { insetos para } \\
\text { biocontrole }\end{array}$ & $\begin{array}{c}\text { Plantas } \\
\text { transgênicas }\end{array}$ \\
\hline \multicolumn{4}{|l|}{ Biologia/ecologia } \\
\hline Taxonomia & $\mathrm{X}$ & $\mathrm{X}$ & $\mathrm{X}$ \\
\hline Afinidades com a biota da NZ & $\mathrm{X}$ & $\mathrm{X}$ & $\mathrm{X}$ \\
\hline Ecologia e distribuição natural das espécies & $\mathrm{X}$ & $\mathrm{X}$ & \\
\hline Fatores eco-climáticos limitando a distribuição na NZ & $\mathrm{X}$ & $\mathrm{X}$ & $\mathrm{X}$ \\
\hline Produtividade e longevidade das sementes & $\mathrm{X}$ & & $\mathrm{X}$ \\
\hline Presença de inimigos naturais & $\mathrm{X}$ & $\mathrm{X}$ & $\mathrm{X}$ \\
\hline Morfologia, dimorfismo sexual, peso e dispersão da planta & $\mathrm{X}$ & & $\mathrm{X}$ \\
\hline Ciclo de vida & $\mathrm{X}$ & $\mathrm{X}$ & $\mathrm{X}$ \\
\hline Modo de reprodução & $\mathrm{X}$ & $\mathrm{X}$ & $\mathrm{X}$ \\
\hline Potencial de hibridização & $\mathrm{X}$ & $\mathrm{X}$ & $\mathrm{X}$ \\
\hline Modo de dispersão & $\mathrm{X}$ & $\mathrm{X}$ & $\mathrm{X}$ \\
\hline Origem do gene & & & $\mathrm{X}$ \\
\hline Onde o gene é expresso & & & $\mathrm{X}$ \\
\hline Qual a função do(s) gene(s) & & & $\mathrm{X}$ \\
\hline Estabilidade da construção, mutações conhecidas. & & & $\mathrm{X}$ \\
\hline $\begin{array}{l}\text { Presença de organismo não modificado aparentado evolutivamente } \\
\text { na NZ }\end{array}$ & & & $\mathrm{X}$ \\
\hline Toxicidade, espinho, odor ofensivo & $\mathrm{X}$ & & $\mathrm{X}$ \\
\hline \multicolumn{4}{|l|}{ História de invasão } \\
\hline História de introdução fora das condições naturais & $\mathrm{X}$ & $\mathrm{X}$ & \\
\hline Invasibilidade & $\mathrm{X}$ & $\mathrm{X}$ & $\mathrm{X}$ \\
\hline Habilidade de se naturalizar & $\mathrm{X}$ & $\mathrm{X}$ & $\mathrm{X}$ \\
\hline Competidores & $\mathrm{X}$ & $\mathrm{X}$ & $\mathrm{X}$ \\
\hline Herbívoros/predadores & $\mathrm{X}$ & & $\mathrm{X}$ \\
\hline Probabilidade de tornar-se presa de espécies existentes & & $\mathrm{X}$ & \\
\hline Habilidade de competir em agroecossistemas específicos na NZ & $\mathrm{X}$ & & $\mathrm{X}$ \\
\hline $\begin{array}{llllll}\begin{array}{l}\text { Plantas conhecidas como difíceis } \\
\text { seletivamente }\end{array} & & & \text { de } & & \\
\end{array}$ & $\mathrm{X}$ & & $\mathrm{X}$ \\
\hline $\begin{array}{l}\text { Seleção de sementes que possam contaminar/desvalorizar lã, pele } \\
\text { ou carne }\end{array}$ & $\mathrm{X}$ & & \\
\hline Suscetibilidade a herbicidas & $\mathrm{X}$ & & $\mathrm{X}$ \\
\hline Tolerância à mutilação, cultivação ou ao fogo & $\mathrm{X}$ & & $\mathrm{X}$ \\
\hline Taxa/Potencial de se tornarem pragas ou ervas invasoras & $\mathrm{X}$ & $\mathrm{X}$ & $\mathrm{X}$ \\
\hline & & & Continua \\
\hline
\end{tabular}




\begin{tabular}{|c|c|c|c|}
\hline Critérios de Biossegurança & $\begin{array}{l}\text { Novas } \\
\text { espécies }\end{array}$ & $\begin{array}{c}\text { Novos } \\
\text { insetos para } \\
\text { biocontrole }\end{array}$ & $\begin{array}{c}\text { Plantas } \\
\text { transgênicas }\end{array}$ \\
\hline \multicolumn{4}{|l|}{ Fontes de risco } \\
\hline Organismo incorretamente identificado & $\mathrm{X}$ & $\mathrm{X}$ & \\
\hline Potencial de se tornar daninho & $\mathrm{X}$ & & $\mathrm{X}$ \\
\hline Hospedeiro alvo conhecido & & $\mathrm{X}$ & \\
\hline Hospedeiro alvo previsto & & $\mathrm{X}$ & \\
\hline Efeitos diretos sobre espécies nativas & $\mathrm{X}$ & $\mathrm{X}$ & $\mathrm{X}$ \\
\hline $\begin{array}{l}\text { Efeitos e caminhos indiretos pelos quais pode afetar outros } \\
\text { organismos }\end{array}$ & $\bar{X}$ & $\bar{X}$ & $\bar{X}$ \\
\hline Transferência de material genético modificado a outros organismos & & & $\mathrm{X}$ \\
\hline Deslocamento de espécies existentes & $\bar{X}$ & $\bar{X}$ & $\bar{X}$ \\
\hline Hibridização com espécies nativas & $\mathrm{X}$ & $\mathrm{X}$ & $\mathrm{X}$ \\
\hline Associações indesejáveis com outros organismos & $\mathrm{X}$ & $\mathrm{X}$ & \\
\hline $\begin{array}{l}\text { Degradação do habitat para espécies nativas } \\
\text { Vetor de doenças para plantas e animais }\end{array}$ & $\mathrm{X}$ & $\begin{array}{l}\mathrm{X} \\
\mathrm{X}\end{array}$ & $\mathrm{X}$ \\
\hline Efeitos sobre os valores da biodiversidade & $\mathrm{X}$ & $\mathrm{X}$ & $\mathrm{X}$ \\
\hline Efeitos sobre a saúde humana & $\mathrm{X}$ & $\mathrm{X}$ & $\mathrm{X}$ \\
\hline Entrada de produtos na cadeia alimentar & & $\mathrm{X}$ & $\mathrm{X}$ \\
\hline Reversibilidade da liberação & $\mathrm{X}$ & $\mathrm{X}$ & $\mathrm{X}$ \\
\hline Valores culturais ambientais a respeito do risco & $\mathrm{X}$ & & $\mathrm{X}$ \\
\hline \multicolumn{4}{|l|}{ Protocolos de Biossegurança } \\
\hline Avaliação de risco a pragas & $\mathrm{X}$ & & $\mathrm{X}$ \\
\hline Centrifugal phylogenetic testing & & $\mathrm{X}$ & \\
\hline Testes de hospedeiros alvos & & $\mathrm{X}$ & \\
\hline Efeitos multitróficos & $\mathrm{X}$ & $\mathrm{X}$ & $\mathrm{X}$ \\
\hline Testes de hibridização & $\mathrm{X}$ & $\mathrm{X}$ & $\mathrm{X}$ \\
\hline
\end{tabular}

Fonte: Modificado de Barrat; Moeed; Malone (2006). 


\section{REGULAÇÃO DE OGMs NO BRASIL}

\subsection{Histórico.}

No Brasil, o debate nacional a respeito de OGMs recebeu destaque a partir de 1998, quando o Instituto de Defesa do Consumidor (IDEC) e o Greenpeace Brasil entraram com uma representação que originou uma medida cautelar do Ministério Público da União contra a decisão da Comissão Técnica Nacional de Biossegurança (CTNBio) de liberar o plantio da primeira variedade GM de uso agrícola no país, a soja Roundup Ready produzida pela Monsanto, em razão das dúvidas existentes sobre a análise de risco apresentada pela empresa e a falta de transparência no processo decisório. Neste momento, formaram-se duas coalizões polarizadas envolvendo os critérios de liberação de OGMs. Uma contrária aos mecanismos vigentes no país, envolvendo produtores rurais, sobretudo ligados à agricultura familiar e de pequena escala, ONGs ambientalistas, IDEC, PROCON, associações científicas, partidos políticos de oposição no momento, Ministério Público Federal, IBAMA, dentre outros. Por outro lado, constituiu-se uma coalizão favorável à liberação dos OGMs nos termos existentes, envolvendo partidos políticos da situação, associações científicas, multinacionais produtoras de OGMs, setores ligados ao agronegócio e órgãos do governo, os quais passaram a identificar os setores oposicionistas como irracionais, catastrofistas e contrários ao progresso científico e econômico da nação (GUIVANT, 2005).

Em 1999, a coalizão contrária à liberação dos OGMs nos termos regulatórios vigentes criou a Campanha por um Brasil Livre de Transgênicos, que teve por objetivo a conscientização pública a respeito dos impactos ocasionados pelos OGMs à saúde e ao meio ambiente, assim como a denúncia sobre o monopólio de corporações multinacionais na produção de sementes transgênicas. Neste cenário, uma ação judicial contra a União foi realizada pelo Ministério Público Federal a pedido do IBAMA e do CONAMA (GUIVANT, 2005).

A partir de 2003, o debate se deu no poder executivo, motivado pelos plantios ilegais em larga escala de soja transgênica no Rio Grande do Sul, momento no qual o governo brasileiro emitiu a Medida Provisória 113/03 que permitiu a comercialização destas safras, prática adotada também nos dois anos seguintes. Ao mesmo tempo, iniciou-se a cobrança de royalties pela Monsanto aos produtores ilegais de soja transgênica, que a introduziram propositalmente e àqueles que tiveram seus cultivos contaminados pelo transgene. A coalizão 
contrária às liberações se fortaleceu nesta etapa, em função do desrespeito governamental à decisão judicial sobre a proibição de OGMs, aos princípios do Protocolo de Cartagena, à obrigatoriedade de rotulagem de alimentos contendo OGMs firmada pelo Decreto 4.680/03, assim como pela ausência de transparência nos processos decisórios (GUIVANT, 2005) ${ }^{3}$.

Com intuito de cessar os conflitos judiciais relacionados às sucessivas medidas provisórias de liberação da soja transgênica, foi proposta, em 2003, a reformulação da Lei de Biossegurança 8974/95. Tal processo foi realizado em três etapas: a criação do projeto de lei, coordenado pela Casa Civil, sua aprovação pelo Congresso Nacional e a posterior regulamentação. Em março de 2004, tramitou na Câmara dos Deputados o Projeto Nacional de Biossegurança, propondo as seguintes principais alterações na Lei 8974/95:

- a reestruturação e limitação da influência da CTNBio (vinculada ao Ministério de Ciência e Tecnologia) nas tomadas de decisões sobre OGMs no país;

- a criação do Conselho Nacional de Biossegurança, com a autoridade sobre a decisão final acerca de OGMs.

O projeto de lei, que se estendeu no Congresso por dois anos em razão de disputas político-partidárias, atendia às reivindicações dos Ministérios da Saúde e do Meio Ambiente, de associações de consumidores e ambientalistas, pois procurava manter a atribuição dos órgãos de registro e fiscalização de OGMs (Ministérios da Saúde, Agropecuária e Abastecimento e Meio Ambiente) para a autorização de pesquisas e comercialização destes organismos no Brasil (GUIVANT, 2005). Entretanto, no Congresso Nacional e, principalmente no Senado, o projeto de lei sofreu modificações e o texto final foi aprovado em 2005, originando a Lei No 11.105/05 (a nova Lei de Biossegurança), sendo as mais significativas relacionadas às atribuições dos órgãos responsáveis pela regulação da Biossegurança no Brasil. Neste sentido, estabeleceu-se a CTNBio como órgão deliberativo sobre as pesquisas e liberações comerciais de OGMs, com a prerrogativa de decidir sobre a realização de estudos de impactos ambientais, enquanto que os Ministérios da Saúde, Meio Ambiente e Agropecuária e Abastecimento passaram a ser órgãos responsáveis pelo registro e fiscalização, seguindo as normas da CTNBio (PELAEZ, 2007).

\footnotetext{
${ }^{3}$ As indústrias tiveram o prazo até 2004 para realizar a rotulagem, com a identificação dos alimentos contendo mais de $1 \%$ de OGMs com a letra "T", o que não se sucedeu, sem punição dos infratores. As justificativas para tanto se concentram na falta de preparo dos laboratórios certificados para o atendimento da demanda, dentre os quais situa-se a própria ANVISA. A única organização existente que realiza testes nos produtos suspeitos de conterem OGMs no Brasil, de forma voluntária, é o Greenpeace Brasil, cujos resultados são divulgados periodicamente por meio das publicações "Guia de Defesa do Consumidor", que podem ser encontradas no síteo eletrônico da ONG: www.greenpeace.org.br.
} 
5.2. Aspectos institucionais e conflitos: normas, participação, acesso às informações e justiça ambiental.

Os conflitos existentes no país a respeito de OGMs abarcam questões como a legitimidade, transparência, legalidade, participação social nas tomadas de decisão sobre as deliberações, o acesso às informações ambientais, os instrumentos ambientais utilizados e aspectos relacionados à justiça ambiental. Dentre as discussões levantadas podem-se citar (NODARI; GUERRA; VALLE，2002; ODA，2003; PELAEZ，2004; PELAEZ, 2007; PESSÔA, 2007; MILARÉ ,2007; CANOTILHO; LEITE, 2007; MINISTÉRIO PÚBLICO FEDERAL, 2007; MINISTÉRIO DO DESENVOLVIMENTO AGRÁRIO, 2007):

- A atribuição da CTNBio como órgão deliberativo sobre transgênicos no Brasil, incluindo a prerrogativa de decidir sobre a necessidade de realização de EIA/RIMA;

- O cumprimento das funções atribuídas à CTNBio;

- A percepção dos riscos ambientais, sociais e econômicos associados aos OGMs;

- A suposta influência das bioindústrias que desenvolvem OGMs sobre as decisões da Comissão;

- Os instrumentos mais adequados para os estudos ambientais necessários às deliberações, sobretudo a Análise de Risco e o Estudo de Impacto Ambiental;

- A participação social previamente às deliberações e a maneira como as argumentações levantadas nas audiências públicas realizadas interferem nos pareceres finais;

- A composição da CTNBio em termos de representação social e quórum mínimo exigido para as decisões;

- A existência de informações ambientais e de cunho socioeconômico suficientes para a realização das análises de risco e estudos de impacto;

- Os procedimentos para o monitoramento ambiental pós-comercial e a existência de informações necessárias para sua eficácia;

- O preparo dos órgãos de fiscalização e monitoramento para o cumprimento de suas atribuições;

- A possibilidade de coexistência entre as variedades transgênicas, convencionais e orgânicas; 


\subsubsection{Conflitos de normas}

Com a aprovação da Lei 11.105/05, estabeleceu-se um conflito de normas no caso de licenciamento ambiental de liberação comercial de OGMs, que apresenta aspectos formais e materiais.

O conflito formal se configura na medida em que o CONAMA, no exercício de suas atribuições, editou a Resolução CONAMA No 237 em 1997, que regulamentou os aspectos de licenciamento ambiental estabelecidos na Política Nacional de Meio Ambiente. No artigo $2^{\circ}$. Parágrafo $2^{\circ}$. menciona que "caberá ao órgão ambiental competente definir os critérios de exigibilidade, o detalhamento e a complementação do Anexo I, levando em consideração as especificidades, os riscos ambientais, o porte e outras características do empreendimento ou atividade". No anexo I, no item uso de recursos naturais, a referida Resolução inclui atividade necessária ao licenciamento ambiental a "introdução de espécies exóticas e/ou geneticamente modificadas".

A Política Nacional do Meio Ambiente (Lei 6938/1981) estabelece competências ao CONAMA, regulamentada pelo Decreto 99.274 de 1990 e ao Sisnama (Sistema Nacional do Meio Ambiente), que confere ao IBAMA (Instituto Brasileiro do Meio Ambiente e dos Recursos Naturais Renováveis) o papel de órgão executivo da Política Ambiental em âmbito Federal.

No caso de licenciamento ambiental, que é um dos instrumentos da PNMA, o artigo 10 da Lei No 6038/81 menciona que o Sisnama - por meio de seus órgãos - e o IBAMA, em caráter supletivo, devem avaliar a necessidade de licenciamento ambiental e os procedimentos para tanto, bem como a concessão e renovação de licença.

Em 1988, todas estas normas foram inteiramente recepcionadas pela Constituição Federal (CF), que menciona em diversos títulos, capítulos e artigos os princípios que regem a matéria ambiental. Cabe mencionar o art. 170, Da ordem econômica e financeira, que considera a função social da propriedade e a defesa do meio ambiente como princípios, conforme os ditames da justiça social. O capítulo Da Política Agrícola e Fundiária e da Reforma Agrária, nos arts. 184 e seguintes, contempla a função social da propriedade rural, que considera a preservação ambiental como um de seus pilares. No artigo 225, no capítulo Do Meio Ambiente, relata que incumbe ao Poder Público: exigir na forma da lei, para a instalação de obra ou atividade potencialmente causadora de significativa degradação do meio ambiente, estudo prévio de impacto ambiental, a que se dará publicidade; controlar a 
produção, a comercialização e o emprego de técnicas, métodos e substâncias que comportem risco para a vida, a qualidade de vida e o meio ambiente; proteger a fauna e flora.

Buscando a regulamentação dos procedimentos que envolvam o licenciamento de atividades relativas a OGMs, o CONAMA editou a Resolução No.260 de 30 de junho de 1999, criando um Grupo de Trabalho para tal finalidade. Desta forma, foi elaborada a Resolução CONAMA No. 305 de 12 de julho de 2002 que dispôs sobre o "Licenciamento Ambiental, Estudo de Impacto Ambiental e Relatório de Impacto no Meio Ambiente de atividades e empreendimentos com Organismos Geneticamente Modificados e seus derivados" e que tem como abrangência as pesquisas em confinamento e a liberação ambiental e comercialização de OGMs.

Dentre os princípios ponderados na referida Resolução se fazem presentes a precaução, participação pública, a garantia de acesso à informação e a publicidade. Quanto às normas, o Código de Defesa do Consumidor e a Lei 8974 de 1995, que foi revogada pela Lei 11.105 de 2005, como anteriormente observado. Para efeito deste trabalho, apenas o licenciamento para liberação comercial será analisado em termos de conflitos com as demais normas vigentes, apesar de constar na Resolução o licenciamento para pesquisa em área confinada e em campo.

A responsabilidade pelo procedimento foi dada ao IBAMA, que deve realizar e considerar o macrozoneamento das áreas para liberação dos OGMs, tendo em vista suas especificidades biogeográficas e sócio-econômicas, assim como os o exame técnico realizado pelos Estados, quando de sua existência. Determina-se a consideração da área de influência do projeto em análise e a apresentação de um plano de contingência em casos de eventual dano ambiental ocasionado pelo OGM. Os seguintes elementos devem ser apresentados ao IBAMA (BRASIL, 2002):

I- o parecer técnico conclusivo da CTNBio;

II- a localização específica da atividade ou do empreendimento;

III- a potencial degradação ambiental;

IV- o efeito do empreendimento sobre as atividades sociais e econômicas;

V- o tamanho e as características do empreendimento;

VI- a presença ou proximidade de parentes silvestres do OGM;

VII- a vulnerabilidade ambiental do local;

VIII- a existência de licença ou pedido de licença ambiental anterior para atividade ou empreendimento envolvendo a mesma construção gênica naquela espécie ou variedade e;

IX- os pareceres técnicos apresentados pelos interessados legalmente legitimados, nos termos da Lei n. 9784 de 29 de janeiro de 1999. 
Assim posto, observa-se que a CTNBio se configura como um órgão consultivo e não deliberativo, como disposto na Lei 11.105, estabelecendo novamente um conflito de normas com esta legislação. Além disto, o parágrafo 6 do artigo 5 determina que o órgão competente tem atribuição para solicitar à CTNBio afirmações adicionais por meio de um novo parecer ou reunião da Subcomissão Setorial para o esclarecimento das questões a serem elucidadas.

Determina-se que outros estudos ambientais podem substituir os Estudos de Impacto Ambientais, mas apenas quando solicitados pelo órgão ambiental competente. No entanto, nas áreas de restrição ambiental para a liberação determinadas pelo macrozoneamento, o EIA é exigido, de acordo com o parágrafo 1 do artigo 6.

A lei 11.105 de 2005, que regulamenta incisos do art. 225 da Constituição Federal, revoga algumas normas vigentes à época, sem menção expressa às normas ambientais mencionadas no presente trabalho. Dentre estas, se encontra a Resolução CONAMA sobre o licenciamento ambiental. Neste sentido, de acordo com o Ministério Público Federal (2007), a atribuição de amplos poderes à CTNBio sobre deliberação de PGMs é inconstitucional, pois a vigilância ao meio ambiente e à saúde pública são incumbências exclusivas dos Ministérios do Meio Ambiente e da Saúde, respectivamente, como determinado na Constituição Federal de 1988 (MINISTÉRIO PÚBLICO FEDERAL, 2007).

Quanto aos conflitos materiais, os princípios gerais do Direto que regem a matéria são inúmeros. Milaré (2007) e Canotilho e Leite (2007) destacam os seguintes princípios: do ambiente ecologicamente equilibrado, natureza pública da proteção ambiental, da prevenção, da precaução, da consideração da variável ambiental no processo decisório de políticas de desenvolvimento, do poluidor-pagador, da função socioambiental da propriedade, da participação da sociedade, entre outros.

Também, há protocolos internacionais que tratam da matéria e que o Brasil é signatário: Declaração do Rio sobre meio ambiente e desenvolvimento, Agenda 21, Convenção sobre Diversidade Biológica, dentre muitos outros. Todos preconizam a justiça ambiental e governança ambiental como procedimentos necessários à matéria.

As normas brasileiras ambientais observam tais princípios gerais e os estabelecidos pelos Acordos Internacionais. Dentre estes, um destaque pode ser dado à Convenção sobre Diversidade Biológica, a qual, especificamente em relação aos OGMs, estabelece como medidas de conservação in situ da biodiversidade a necessidade de desenvolver ou manter: 
biotecnologia que provavelmente promovem impacto ambiental negativo que possa afetar a conservação e a utilização sustentável da diversidade biológica, levando também em conta os riscos para a saúde humana.

Em relação aos princípios presentes nas normas nacionais, pode-se citar a Política Nacional de Biodiversidade, instituída pelo Decreto No 4339 de 22 de agosto de 2002, que tem por princípios norteadores o reconhecimento intrínseco da biodiversidade; o direito soberano dos países no tocante ao uso dos recursos de sua biodiversidade e o dever de sua proteção; a responsabilidade dos países desenvolvidos no aporte de recursos financeiros para as medidas de proteção da biodiversidade nas nações subdesenvolvidas; a internalização dos custos ambientais nas atividades humanas, com aplicação do princípio do poluidor-pagador; o consentimento prévio das comunidades tradicionais em ações relacionadas ao seu conhecimento; a utilização da abordagem ecossistêmica como forma de gestão e a integração entre as ações nacionais relacionadas à biodiversidade (BRASIL, 2002b).

A Agenda 21 Nacional também se configura como um norteador à matéria, em seu capítulo sobre a agricultura sustentável, dispondo o seguinte em relação aos OGMs (MINISTÉRIO DO MEIO AMBIENTE, 2004, p.61):

Adotar o 'princípio da precaução' em relação ao uso e plantio de alimentos transgênicos vegetais e animais, até que se tenham informações científicas claras e precisas, assim como o consenso da sociedade, sobre todos os aspectos jurídicos, de segurança ambiental e de saúde, que envolvem esses insumos.

Criar obrigatoriedade de rotulagem visível para os produtos transgênicos, cuja produção e comercialização tenham sido liberadas, de acordo com o 'princípio da precaução'.

Deste modo, os conflitos formais e materiais existentes no país no tocante à regulação dos OGMs se dão principalmente entre as normas e princípios ambientais.

\subsection{2. Órgãos constituintes e participação social}

A Lei de Biossegurança estabelece a composição da CTNBio em 27 membros, escolhidos perante o critério de competência acadêmica, avaliada pela posse de título de doutorado nas áreas de biotecnologia, biossegurança, biologia, saúde humana e animal e meio ambiente, do seguinte modo (BRASIL, 2005, cap. III, art.11): 
I - 12 (doze) especialistas de notório saber científico e técnico, em efetivo exercício profissional, sendo:

a) 3 (três) da área de saúde humana;

b) 3 (três) da área animal;

c) 3 (três) da área vegetal;

d) 3 (três) da área de meio ambiente;

II - um representante de cada um dos seguintes órgãos, indicados pelos respectivos titulares:

a) Ministério da Ciência e Tecnologia;

b) Ministério da Agricultura, Pecuária e Abastecimento;

c) Ministério da Saúde;

d) Ministério do Meio Ambiente;

e) Ministério do Desenvolvimento Agrário;

f) Ministério do Desenvolvimento, Indústria e Comércio Exterior;

g) Ministério da Defesa;

h) Secretaria Especial de Aqüicultura e Pesca da Presidência da República;

i) Ministério das Relações Exteriores;

III - um especialista em defesa do consumidor, indicado pelo Ministro da Justiça;

IV - um especialista na área de saúde, indicado pelo Ministro da Saúde;

$\mathrm{V}$ - um especialista em meio ambiente, indicado pelo Ministro do Meio

Ambiente;

VI - um especialista em biotecnologia, indicado pelo Ministro da

Agricultura, Pecuária e Abastecimento;

VII - um especialista em agricultura familiar, indicado pelo Ministro do

Desenvolvimento Agrário;

VIII - um especialista em saúde do trabalhador, indicado pelo Ministro do Trabalho e Emprego.

Os especialistas que constam no inciso I são escolhidos pelo Ministério da Ciência e Tecnologia, a partir de lista tríplice, com a participação de sociedades científicas, da Sociedade Brasileira para o Progresso da Ciência e da Academia Brasileira de Ciências; os representantes do inciso II são escolhidos pelos respectivos titulares dos Ministérios de Estado, enquanto que os membros dos incisos III a VIII são também escolhidos pelos respectivos Ministros de Estado perante a apresentação de listas tríplices elaboradas pelas organizações da sociedade civil de personalidade jurídica, cujo objetivo social seja compatível com a área designada, em procedimento elaborado pelos Ministérios. O Mandato dos membros da CTNBio são de dois anos, podendo ser prorrogado para mais dois períodos consecutivos. Seus suplentes têm direito à voz e a voto no caso da ausência de seu titular, durante as deliberações (BRASIL, 2005). Observando-se a atual composição da CTNBio, dentre os representantes do inciso III a VIII, apenas os especialistas em defesa do consumidor, em saúde e em biotecnologia foram nomeados e a grande maioria dos membros atuam na área de biotecnologia e bioquímica.

Durante as consultas e deliberações sobre os pareceres submetidos à Comissão, os membros titulares devem manifestar seu impedimento para as análises caso haja algum 
conflito de interesses. O Presidente da CTNBio é designado, entre os seus membros, pelo Ministro da Ciência e Tecnologia, a partir de listra tríplice votada pelo plenário e tem como funções: apoiar tecnicamente e administrativamente os membros da CTNBio; receber, tramitar e instruir os pleitos submetidos à Comissão; encaminhar as deliberações aos órgãos governamentais e lhes dar publicidade, além de atualizar o Sistema de Informações sobre Biossegurança (SIB), cuja criação é prevista na Lei 11.105. Os representantes da Comissão participam das subcomissões setoriais permanentes nas áreas de saúde humana e animal, meio ambiente e vegetal, que analisam os temas dispostos nos plenários. As decisões tomadas, incluindo os votos de cada membro da Comissão, devem constar no SIB, de forma fundamentada (BRASIL, 2005).

Os extratos prévios dos pleitos devem ser dispostos no Diário Oficial da União (D.O.U.) com 30 dias de antecedência de sua colocação em pauta, com exceção das situações de urgência definidas pelo presidente da Comissão. Da mesma forma, os pareceres e as decisões técnicas devem ser publicados no D.O.U. Os órgãos da administração pública federal podem participar das reuniões da CTNBio, sem direito a voto, perante justificativas à Secretaria Executiva que comprovem o interesse da entidade na biossegurança dos OGMs em análise. Já os representantes das comunidades científicas, setor público e sociedade civil poderão comparecer às reuniões caso sejam convidados, também sem direito a voto (BRASIL, 2005b).

Os processos submetidos à CTNBio seguem os seguintes trâmites (BRASIL, 2005):

1. São protocolados na Secretaria Executiva da CTNBio e seu extrato prévio é divulgado no D.O.U. e no SIB;

2. O processo é distribuído a um dos membros da Comissão, que elabora um relatório e um parecer;

3. Este parecer é submetido às subcomissões permanentes ou extraordinárias para a elaboração de um parecer final;

4. Os relatores das subcomissões permanentes ou extraordinárias devem considerar, além do relatório apresentado pelo proponente, a literatura científica existente e os documentos protocolados nas audiências públicas ou na CTNBio;

5. O parecer final, após aprovado pelas subcomissões, é encaminhado para o plenário da CTNBio, para deliberação;

6. O voto vencido de membro(s) das subcomissões setoriais é apresentado de maneira fundamentada e exposto como voto divergente no parecer final para a apreciação e deliberação no plenário; 
7. As informações sigilosas, de interesse comercial, deverão ser resguardadas pela CTNBio quando solicitadas pelo proponente, desde que não afetem os interesses individuais ou coletivos assegurados constitucionalmente. Estas informações devem ser fundamentadas e solicitadas ao Presidente da CTNBio e podem ser sujeitas a indeferimento também fundamentado, garantido o recurso contrário ao proponente, que deverá ser julgado em plenário. Até a decisão final, o sigilo deve ser garantido. Caso o recurso seja negado ao proponente, este pode desistir do pedido. Os órgãos de registro e fiscalização poderão solicitar o acesso às informações sigilosas, caso seja indispensável à consecução de suas tarefas, com fundamentação e indicação do agente a que caberá o acesso;

8. Os órgãos de registro e fiscalização devem obedecer, quanto ao aspecto de biossegurança de OGMs e derivados, a decisão da CTNBio;

9. A decisão final da CTNBio deve ter sua fundamentação resumida, explicitando as medidas de biossegurança a serem adotadas, as restrições de uso e considerando as particularidades das diferentes regiões do país, a fim de subsidiar as ações dos órgãos de registro e fiscalização;

10. O derivado de OGM que já tenha sido aprovado anteriormente pela Comissão não se sujeitará a novo processo, sendo aprovado para suas finalidades automaticamente;

As instituições que pretendam realizar pesquisa em laboratório com OGMs e seus derivados ou liberações planejadas que se objetivem a desenvolver ou avaliar a biossegurança do OGM, abrangendo sua construção, cultivo, manipulação, transporte, armazenamento, importação, exportação, transferência, liberação ambiental ou descarte, devem solicitar à CTNBio a emissão de um Certificado de Qualidade em Biossegurança (CQB). Quando concedido, a Comissão envia cópias e atualizações do CQB aos órgãos de registro e fiscalização, para o exercício de suas funções. As entidades que não apresentarem o Certificado quando solicitado serão co-responsabilizadas pelos efeitos decorrentes do descumprimento das normas da CTNBio (BRASIL, 2005).

A criação de Comissões Internas de Biossegurança (CIBio) também é obrigatória pelas mesmas entidades referidas, cujos mecanismos de funcionamento são estipulados pela CTNBio, sendo necessária a indicação de um técnico responsável. Dentre as competências desta Comissão encontram-se: a comunicação aos trabalhadores e à coletividade sobre questões relacionadas à biossegurança, quando da ocorrência de acidentes; a criação de procedimentos preventivos e de inspeção que garantam a biossegurança de suas atividades; encaminhar documentações à CTNBio para análise e autorização do órgão competente; registrar o acompanhamento da atividade; notificar a CTNBio, trabalhadores e demais pessoas 
expostas sobre o resultado das análises de risco, assim como incidentes e acidentes envolvendo a disseminação do material biológico, além de investigar enfermidades e acidentes relacionados ao OGM ou derivados, com notificações enviadas à CTNBio (BRASIL, 2005).

Outro órgão criado pela Lei de Biossegurança de 2005 foi o Conselho Nacional de Biossegurança, cuja principal função é assessorar o Presidente da República na formulação e implementação da Política Nacional de Biossegurança (PNB), ainda não elaborada. O objetivo da PNB é determinar diretrizes técnicas e práticas para garantir a biossegurança da manipulação de seres vivos pela engenharia genética, explicitando seus princípios norteadores, mecanismos de gestão e as responsabilidades dos órgãos responsáveis pela gestão, dentre outros aspectos (MILARÉ, 2007). O CNBS é formado pelos seguintes Ministros:

I - Ministro de Estado Chefe da Casa Civil da Presidência da República, que o presidirá;

II - Ministro de Estado da Ciência e Tecnologia;

III - Ministro de Estado do Desenvolvimento Agrário;

IV - Ministro de Estado da Agricultura, Pecuária e Abastecimento;

V - Ministro de Estado da Justiça;

VI - Ministro de Estado da Saúde;

VII - Ministro de Estado do Meio Ambiente;

VIII - Ministro de Estado do Desenvolvimento, Indústria e Comércio

Exterior;

IX - Ministro de Estado das Relações Exteriores;

X - Ministro de Estado da Defesa;

XI - Secretário Especial de Aqüicultura e Pesca da Presidência da República.

(BRASIL, 2005, art. 49)

Além da elaboração da PNB, as atribuições do CNBS são as seguintes (BRASIL, 2005):

1. Elaborar diretrizes e princípios para os órgãos governamentais e entidades federais competentes;

2. Analisar, quando solicitado pela CTNBio, os pedidos de liberação comercial de OGMs, tendo em vista os interesses nacionais e as oportunidades socioeconômicas do país;

3. Decidir em última instância, com manifestação da CTNBio e, se necessário, dos órgãos de registro e fiscalização, a respeito das liberações comerciais de OGMs. Quando aprovada a liberação, deve apresentá-la aos órgãos de registro e fiscalização e quando decidir contrariamente, deve manifestar-se à CTNBio, para que informe o requerente;

Além da CTNBio e do CNBS, o sistema regulatório compõe-se pelos órgãos de 
registro e fiscalização das atividades relacionadas ao uso de OGMs, quais sejam, o Ministério da Saúde, Ministério da Agricultura, Pecuária e Abastecimento, Ministério do Meio Ambiente e Secretaria Especial de Aqüicultura e Pesca da Presidência da República.

Cabe lembrar que a CTNBio tem a incumbência de decidir se a atividade em questão é ou não potencialmente poluidora, condicionando-a à realização de EIA/RIMA. Os registros, autorizações e licenciamentos ambientais (quando da realização de EIA/RIMA) devem ocorrer no prazo de 120 dias, com suspensão de até 180 dias para os estudos e esclarecimentos realizados pelo requerente. Tais órgãos devem seguir as decisões técnicas estipuladas pela CTNBio, estando impossibilitados de realizar outras exigências em matéria de biossegurança, e suas ações podem se dar conjuntamente (BRASIL, 2005).

O quórum mínimo para as deliberações da CTNBio foi motivo de impasses desde o momento da tramitação do projeto de reformulação da Lei 8974/95. Quando submetida à sanção presidencial, a nova lei de Biossegurança apresentou vetos em sete artigos, dentre os quais cabe citar: "As decisões da CTNBio serão tomadas por maioria dos membros presentes à reunião, respeitado o quórum [mínimo de 14 membros] previsto no $\S 7^{\circ}$. deste artigo" (BRASIL, 2005, artigo 11, parágrafo 8), tendo como justificativa a complexidade do assunto em questão. Deste modo, os processos submetidos não poderiam ser decididos por oito cidadãos, mesmo que academicamente qualificados, já que o quórum para a realização das reuniões é de 14 membros e sua maioria, portanto, constituída por oito pessoas (BRASIL, 2005). Tal alteração foi motivo de diversas discussões entre representantes de setores variados da sociedade, partidos políticos e órgãos ministeriais competentes, sendo solucionada com uma sanção presidencial que determinou o quórum mínimo de $2 / 3$ da totalidade dos membros da Comissão. Uma das manifestações contrárias a tal decisão foi feita pelo presidente da Federação dos Agricultores do Rio Grande do Sul, a FARSUL: "Lastimo que todas as ações do [Ministério] do Meio Ambiente sejam para dificultar e atrasar os procedimentos. Como se isso viesse a segurar o avanço da biotecnologia”. (FARSUL apud PELAEZ; SCHIMIDIT, 2000, p. 12).

O Presidente da Comissão de Agricultura da Câmara dos Deputados, Ronaldo Caiado, que também discordou do veto, levantou a possibilidade de reverter a decisão presidencial, afirmando que a "bancada que representa os grandes produtores rurais no Congresso é numerosa e muito articulada" (ZANATTA, 2005 apud PELAEZ, 2007). Em razão de diversas manifestações contrárias provenientes de produtores rurais, biotecnólogos, empresas de biotecnologia, dentre outros, que viam neste quórum mínimo de 2/3 uma inviabilização das 
liberações de OGMs, o governo editou a Medida Provisória 327, diminuindo-o para a maioria absoluta dos membros da Comissão (PELAEZ, 2007).

Com relação às nomeações dos membros da Comissão, Zanatta (2007 apud PELAEZ, 2007) aponta para a irregularidade da nomeação do representante do Ministério da Saúde. De acordo com a nova lei, cabe ao Ministro da Saúde escolher seu representante na Comissão, a partir de uma lista tríplice indicada por seus pares. No entanto, sem atender ao disposto em lei, o Ministro indicou diretamente seu representante, sem avaliar qualquer lista tríplice. Em razão deste fato, algumas ONGs ambientalistas interpuseram um recurso no Ministério Público Federal, que entrou com uma ação civil pública contra a referida nomeação. Entretanto, a liminar foi negada (ZANATTA, 2007 apud PELAEZ, 2007).

Dentre este fato, suspeitas quanto à falta de transparência nos processos decisórios da CTNBio foram levantadas pelo Ministério Público, que decidiu por nomear a procuradora Maria Soares Cordiolli para assistir suas reuniões, gerando constrangimentos entre alguns de seus membros e a aprovação dos Ministérios do Meio Ambiente e do Desenvolvimento Agrário, que viram nesta decisão a possibilidade de contribuir para uma maior transparência na Comissão. A ação da procuradora, inicialmente, foi pedir a seus membros uma declaração de conflitos de interesse, prevista na lei de biossegurança, mas que até então não havia sido realizada (PELAEZ, 2007).

Em relação à participação direta da sociedade nas discussões sobre os pleitos, a Lei 11.105 permitiu a realização de audiências públicas, mediante os seguintes requisitos: quando solicitada por algum de seus membros e aprovada por maioria absoluta e/ou solicitada por parte comprovadamente interessada quando se tratar de liberação comercial, estando submetida à aprovação por maioria absoluta da CTNBio. Caso aprovada, a coordenação da audiência é realizada pelo Presidente da CTNBio, o qual escolhe seus expositores, apresenta a matéria em questão e abre as discussões para os interessados. Após o término, as manifestações, opiniões, sugestões e documentos ficam disponíveis na Secretária Executiva aos interessados, como o requerente do processo ou pessoa jurídica que tenha função social relacionada à matéria em questão (BRASIL, 2005).

Até o momento, foram liberadas dezesseis variedades de PGMs para plantio em escala comercial no país, sendo que três variedades de milho OGM e cinco de algodão foram submetidas a audiências públicas, todas realizadas via mandatos judiciais. No entanto, as variedades de milho foram submetidas em conjunto a uma só audiência, o mesmo se sucedendo para com as variedades de algodão. 
Nota-se deste modo a existência de um conflito entre os diversos setores da sociedade interessados nas tomadas de decisão sobre OGMs quanto aos atores que possuem legitimidade para participar nestes processos, um fato não isolado no Brasil, mas que ecoa mundialmente.

\subsubsection{Aspectos relacionados à justiça ambiental}

A justiça ambiental diz respeito às formas como riscos ambientais são distribuídos na sociedade (NUSDEO, 2006). Caso ocorram de forma desproporcional, sobretudo às populações com menos recursos políticos e de acesso às informações, utiliza-se o termo injustiça ambiental (ACSERLRAD; MELLO, BEZERRA, 2009).

Um dos aspectos relevantes para possibilitar a justiça ambiental em se tratando de OGMs de aplicação agrícola no Brasil é a garantia de escolha do agricultor em adotar o sistema de plantio que melhor lhe prouver, seja este convencional, transgênico ou orgânico, sem afetar os direitos dos demais neste mesmo sentido, assim como o direito coletivo ao meio ambiente ecologicamente equilibrado, ao bem-estar e à saúde. A informação adequada ao consumidor final dos produtos também merece destaque neste item, como a menção nos rótulos dos produtos.

No Brasil, apenas o sistema de cultivo orgânico apresenta requisitos próprios de identificação e um sistema definido de controle, representado pelo Sistema de Avaliação da Conformidade Orgânica, presentes na Lei Federal No. 10831, de 23 de dezembro de 2003, denominada de Lei de Orgânicos. A fim de se assegurar a procedência orgânica do alimento, o produto deve passar por um sistema de certificação, sendo o agricultor infrator sujeito a processo administrativo, sanções econômicas e, dependendo do caso, até mesmo à inutilização de sua produção (BRASIL, 2007).

A implementação de sistemas produtivos paralelos ao orgânico é permitida desde que se garanta a separação dos produtos nas etapas de plantio, processamento e armazenamento, por meio de seu isolamento espacial e temporal (BRASIL, 2007, cap.II, seção II, art. 7, parág, 1, 2 e 3). Além disto, a produção orgânica não pode conter qualquer traço de modificação genética, nem mesmo no limite de $1 \%$ exigido legalmente para a rotulagem (BRASIL, 2007).

Pelas disposições da regulamentação deste sistema agrícola, a produção de alimentos orgânicos como um todo depende de uma rede fiscalizadora estruturada. No entanto, de acordo com diversas denúncias relatadas pelo Ministério Público Federal, agricultores orgânicos e organizações não governamentais, evidenciadas pela constatação da presença adventícia de OGMs em sistema de plantios orgânicos e convencionais (acima de 1\%), há 
falhas no processo de fiscalização realizado pelo MAPA, MS e MMA, fato que vem sendo desconsiderado quando da autorização de plantios geneticamente modificados pela CTNBio (BRASIL, 2007).

Assim como para o agricultor orgânico, que necessita de garantias legais para assegurar seu sistema de plantio, o consumidor também deve ter acesso às informações sobre a procedência dos produtos alimentícios, como expresso no Código de Defesa do Consumidor. Em relação aos alimentos OGMs ou que os contenha, uma forma para permitir tal acesso é a identificação dos produtos contendo traços de transgenia acima de $1 \%$ por meio de rotulagem o que, apesar de legalmente garantido, não vem sendo cumprido no país, dada a ausência de fiscalização e punição das empresas contraventoras, como anteriormente mencionado.

Além dos produtores de orgânicos, aqueles que recebem créditos do Programa Nacional de Agricultura Famíliar (PRONAF) também podem ser vitimizados pelo plantio de transgênicos nas adjascências de suas propriedades, caso estes se dêem sem os cuidados necessários para evitar a propagação de estruturas reprodutivas. Segundo o Ministério Público Federal (2007), existem 4,2 milhões estabelecimentos familiares no Brasil, que participam de $10 \%$ do PIB das cadeias agropecuárias, produzindo a maior parte dos alimentos destinados ao consumo humano no país. O crédito é concedido apenas às famílias cujas lavouras estejam incluídas no zoneamento agrícola do MAPA, mas aquelas que utilizam sementes crioulas ou tradicionais como cultivo são tratadas com excepcionalidade, podendo receber o custeio do PRONAF.

Devido à ausência, no país, de zoneamento agrícola para o plantio comercial de transgênicos, o Ministério de Desenvolvimento Agrário levantou a questão da falta de amparo legal para estas famílias receberem o crédito do PRONAF, por conta da possibilidade de contaminação das variedades crioulas pelas PGMs (MINISTÉRIO DO DESENVOLVIMENTO AGRÁRIO, 2007).

A Política Nacional de Assistência Técnica e Extensão Rural, do qual o PRONAF participa, não reconhece o sistema agrícola transgênico como favorável ao desenvolvimento da agricultura brasileira, especialmente à agricultura familiar, e tem por objetivo a transição de sistemas agrícolas baseados no uso de agroquímicos para sistemas de base ecológica e, deste modo, a assistência não apoia as associações e entidades que atuem com agricultores que cultivem PGMs (MINISTÉRIO DO DESENVOLVIMENTO AGRÁRIO, 2007). Neste sentido, caso haja contaminação das lavouras dos pequenos produtores rurais por material 
transgênico, os créditos agrícolas que as mantêm são perdidos, o que configua um caso de injustiça ambiental.

Outro aspecto conflituoso em matéria de justiça ambiental relacionada aos OGMs no Brasil é dado pela não existência de monitoramento ambiental pós-comercial, mesmo que previsto na Lei Biossegurança 11.105. Inclusive, o monitoramento não é pré-requisito para a tomada de decisões sobre a liberação de OGMs, devendo ser apresentado pelo proponente após 30 dias a partir da concessão da liberação (CTNBio, 2005). Além disto, os termos para o monitoramento não foram normatizados pela Comissão. Estes fatos são motivos de constestação por diversos setores da sociedade, que pensam ser indispensáveis a apresentação do Plano de Monitoramento e sua aprovação durante o processo decisório e não após sua conclusão. Até a presente data nenhuma empresa que comercializa OGMs no país efetua o monitoramento.

Para tais setores, a inexistência de monitoramento impossibilita a detecção de danos ambientais e à saúde, incorrendo em um ônus muitas vezes irreparável aos sistemas biológicos e populações humanas afetadas. A fiscalização e o monitoramento são indispensáveis para a garantia da integridade dos cultivos e dos alimentos de origem convencional e orgânica minimizando, deste modo, o escape gênico que pode ocorrer por cruzamento destas variedades com as transgênicas pela polinização, com a deposição de sementes GMs em áreas inadequadas durante seu transporte e com eventuais mistura de variedades no processo de armazenamento. A ausência destes mecanismos impede que medidas de prevenção e reparação de danos sejam executadas (MINISTÉRIO PÚBLICO FEDERAL, 2007). No entanto, segundo Greiner e Konietzny (2008), a fim de possibilitar a rastreabilidade e rotulagem de produtos contendo OGMs, se faz necessária uma maior demanda por laboratórios credenciados para a realização de testes de detecção.

A caracterização de um sistema regulatório de recursos naturais como sendo ambientalmente justo passa pela forma como os órgãos decisórios conduzem a mediação dos conflitos existentes, de modo a evitar que benefícios e danos sejam desigualmente distribuídos pelos grupos sociais afetados (PETKOVA et al., 2002). Alguns casos emblemáticos que possibilitam uma análise geral desta questão no Brasil são apresentados a seguir.

O caso da soja resistente ao glifosato, da Monsanto, é um dos mais comentados na literatura. Esta variedade foi ilegalmente introduzida no país, em larga escala, durante a década de 1990, provavelmente por meio da Argentina. Não obstante tal contravenção, pressões políticas da bancada ruralista do Congresso Nacional e de organizações de 
agricultores da região Sul ligados ao agronegócio clamando pela liberação das safras de 2002 e 2003 contendo soja transgênica, conduziram o governo federal a editar as Medidas Provisórias No. 113, de 26 de março de 2003 e No. 131, de 25 de setembro de 2003, esta última convertida no Decreto No. 10.814, de 15 de dezembro de 2003. Tal Decreto responsabilizou o agricultor aos danos ambientais e econômicos ocasionados pela presença adventícia de soja transgênica em sua lavoura, independentemente de ser produtor ou não desta variedade. Além disto, viabilizou a cobrança, por parte da Monsanto, dos royalties das sementes contaminadas pelo transgene (MINISTÉRIO PÚBLICO FEDERAL, 2007).

Em 2004, outra Medida Provisória (No. 223, de 14 de outubro de 2004) visando autorizar a safra ilegal de 2004/2005 foi editada, mantendo os mesmos dispositivos da MP anterior. Deste modo, independentemente de o agricultor ter ou não introduzido tais variedades propositalmente, ficou novamente sujeito ao pagamento de indenizações pelos possíveis danos ocasionados, assim como o pagamento de royalties. Neste sentido, tendo em vista o Princípio da Precaução e a inconstitucionalidade das referidas Medidas Provisórias, o Ministério Público Federal, por solicitação do Instituto de Defesa do Consumidor, entrou com uma Ação Civil Pública contra União Federal e o estado do Rio Grande do Sul, em função da permissão de cultivo de uma variedade GM sem análise prévia de biossegurança, a qual foi indeferida (MINISTÉRIO PÚBLICO FEDERAL, 2007).

Outra evidência sobre a adoção da política "do fato consumado" em assuntos relativos aos OGMs foi a autorização, pela CTNBio, da comercialização da safra de algodão 2004/2005 que continha presença adventícia de algodão Bt em $1 \%$, até então proibido no país. Neste momento, o Ministério do Meio Ambiente entrou com recurso administrativo contra a autorização, alegando a ausência de avaliações de risco ambiental e à saúde do algodão transgênico exigidas de modo prévio às liberações e o descumprimento do quórum mínimo exigido nas tomadas de decisão da CTNBio. No entanto, a decisão judicial final terminou por ser favorável à CTNBio e a safra foi liberada (MINISTÉRIO PÚBLICO FEDERAL, 2007).

Conflitos judiciais foram também suscitados com a liberação das variedades de milho transgênico Liberty Link, desenvolvido pela Bayer, MON 810, da Monsanto e Bt11, da Syngenta. Em 15 de junho de 2006, organizações da sociedade civil, como Terra de Direitos, IDEC, ASP-TA e ANPA solicitaram uma ação civil pública contra a União, com o objetivo de anular a decisão favorável da CTNBio pela liberação comercial da variedade, alegando uma série de afrontas à legislação brasileira ao longo do processo decisório, quais sejam: ausência de normatização que orientasse a CTNBio para a avaliação da biossegurança de OGMs; falta de regras de monitoramento e coexistência com o milho convencional e 
orgânico; desconsideração dos documentos apresentados por diversas organizações da sociedade civil no processo e insuficiência de informações prestadas pela proponente que assegurassem a biossegurança do produto. Em julho do mesmo ano, o IBAMA e a ANVISA apresentaram recurso no CNBS contra a decisão da CTNBio de liberar o milho LL. Deste modo, a Comissão foi judicialmente obrigada a condicionar a liberação do milho transgênico a uma medida de coexistência, fixando a distância mínima de 100m entre o milho GM e não modificado, por meio da Resolução Normativa No. 04, de agosto de 2007. No entanto, em razão do apontamento, por diversos agrônomos, sobre a ineficácia da distância mínima estabelecida para evitar o cruzamento entre as variedades de milho, o Ministério Público entrou novamente com ação contra a decisão da CTNBio, alegando sua desobediência ao princípio da precaução, não obtendo sucesso (THUSWOHL, 2007).

O direito dos cidadãos brasileiros à informação se faz presente na Constituição Federal de 1988, sob o artigo $5^{\circ}$, no capítulo sobre os direitos e deveres individuais e coletivos do título II. Especificamente em relação ao meio ambiente, a Política Nacional de Meio Ambiente apresenta como um dos instrumentos para o cumprimento dos objetivos de sustentabilidade econômica, ambiental e social, o sistema nacional de informações sobre o meio ambiente, por meio do artigo $9^{\circ}$, inciso VII o qual, no entanto, ainda não se encontra regulamentado pelo Conselho Nacional do Meio Ambiente. Buscando suprir tal vazio regulatório, em 2003, o Congresso Nacional aprovou a Lei No. 10.650, denominada Lei de Acesso à Informação Ambiental, pela qual os órgãos públicos pertencentes ao SISNAMA ficam obrigados a permitir o livre acesso “[...] aos documentos, expedientes, e processos administrativos que tratem de matéria ambiental e a fornecer todas as informações ambientais que estejam sob sua guarda, em meio escrito, visual, sonoro ou eletrônico [...] (BRASIL, 2003, art.02), sendo que, dentre as principais atividades ressaltadas, encontram-se aquelas relacionadas aos organismos geneticamente modificados.

Um dos instrumentos dispostos legalmente para a garantia de informações ambientais sobre os OGMs no Brasil é a rotulagem dos produtos alimentícios destinados ao ser humano e demais animais, regulamentada pelo Decreto No. 4680 de 24 de abril de 2003, mas que não se encontra efetivada. Visando seu estabelecimento, o governo federal definiu o ano de 2004 como prazo final para as empresas se adequarem à norma e efetuar a rotulagem de seus produtos, identificando os alimentos contendo mais de $1 \%$ de OGMs com a letra "T". No entanto, o mesmo não se sucedeu, sob as justificativas da falta de preparo dos laboratórios certificados pelo governo para o atendimento da demanda, dentre os quais se encontra a 
própria ANVISA. Deste modo, até o presente, a rotulagem de produtos sendo ou contendo OGMs não se encontra implementada no país.

Este tema tem suscitado controvérsias no país, assim como em outros países que comercializam OGMs, sendo que os setores contrários à rotulagem a apontam como uma barreira desnecessária ao comércio de produtos que foram considerados seguros após a aprovação das autoridades competentes (ODA, 2003).

Como outro modo de garantir o acesso às informações sobre OGMs, foi prevista na Lei No. 11.105 de 2005 a criação do Sistema Nacional de Informações em Biossegurança (SIB), vinculado à Secretaria Executiva da CTNBio e que tem por finalidade a "[...] gestão das informações decorrentes das atividades de análise, autorização, registro, monitoramento e acompanhamento das atividades que envolvam OGM e seus derivados" (BRASIL, 2005, cap.VI, artigo 19). Todos os órgãos responsáveis pela regulação de OGMs no país integram o SIB e devem colaborar com o aporte de informações, como a CTNBio, o CNBS e os órgãos de registro e fiscalização. Dentre as informações a serem divulgadas, se encontram as leis regulamentares que alterem e complementem a legislação de biossegurança de OGMs e as obtidas pelos órgãos de registro e fiscalização. Cabe à CTNBio, por meio deste Sistema, dar publicidade à suas atividades, como as agendas de trabalho, calendários de reuniões, processos em tramitação e seus relatores, relatórios anuais, atas de reuniões e outras informações, excluindo aquelas de conteúdo sigiloso. Para seu funcionamento, se faz necessária a interação eletrônica entre o CNBS, a CTNBio e os órgãos de registro e fiscalização de OGMs. Entretanto, o SIB ainda não se encontra implementado, sendo as informações relativas aos processos, avaliações, aprovações e legislações sobre biossegurança não sistematizados.

No meio eletrônico, informações dispersas são encontradas nos órgãos que compõem o sistema regulatório de OGMs, principalmente a CTNBio, o Ministério da Agricultura e a ANVISA. No portal da CTNBio estão presentes os documentos que se relacionam a suas funções, como: processos e pareceres técnicos sobre os pedidos de liberação comercial e importação de OGMs, atas e calendários de reuniões, documentos publicados no Diário Oficial da União, relatórios anuais, declarações de voto, legislação de biossegurança e as normativas elaboradas pela Comissão. No entanto, outros documentos fundamentais como os critérios utilizados pelo órgão para a avaliação dos processos não se encontram disponíveis. Além disto, não há elementos que possibilitem interações com os órgãos de registro e fiscalização e o CNBS, como previsto no SIB (MINARÉ, 2008). 
O Ministério da Agricultura, Pecuária e Abastecimento, por sua vez, apresenta os registros dos cultivares liberados comercialmente, as Instruções Normativas e Portarias do MAPA, os Atos do CNBS e da CTNBio, a lista dos Laboratórios credenciados para a detecção, identificação e quantificação de OGMs, mas não apresenta os relatórios sobre a fiscalização de atividades envolvendo OGMs em território nacional. Já o portal da ANVISA apresenta a legislação pertinente e notícias dispersas, também sem sistematização, enquanto que os portais do Ministério do Meio Ambiente e do IBAMA não apresentam informações sobre o tema.

\subsubsection{Instrumentos de estudos ambientais}

Outro conflito sobre OGMs existente no país e que também gera controvérsias em âmbito internacional diz respeito ao instrumento de estudo ambiental a ser adotado para a avaliação dos potenciais impactos ambientais e sócio-econômicos previamente às tomadas de decisão sobre a liberação comercial destes organismos.

Enquanto alguns atores sociais são favoráveis ao uso das Análises de Risco como ferramenta única de avaliação, seguindo as recomendações da Organização Mundial da Saúde, FAO, Protocolo de Cartagena, dentre outros (ODA, 2003), outros argumentam sobre a necessidade de realização de Estudos de Impacto Ambiental em conjunto com as Análises de Risco, sendo estas constituintes do EIA, como uma metodologia de identificação de possíveis impactos (PESSÔA, 2007).

Outro argumento em torno do EIA reside na existência da Resolução CONAMA 305/02, que dispõe sobre o licenciamento de OGMs por meio de EIA (dentre outros estudos) para a liberação comercial de PGMs, como visto anteriomente. Como já observado, a decisão sobre a realização de EIA cabe à CTNBio, não tendo sido solicitada até o momento em nenhum caso prático (MINISTÉRIO PÚBLICO FEDERAL, 2007).

As principais críticas em torno da análise de risco como ferramenta única são a desconsideração dos aspectos sociais e econômicos nas tomadas de decisão e das implicações políticas e estratégicas da comercialização de PGMs no país (NODARI; GUERRA; VALLE, 2002; PELAEZ, 2004; PESSÔA, 2007).

Neste sentido, com o intuito de investigar a existência de visões conflitantes sobre o tema, procedeu-se à avaliação de um estudo de caso de liberação comercial de PGM, exemplificado pelo algodão Roundup Ready evento MON 1445 da empresa Monsanto, e a 
aplicação de um questionário aos agentes sociais envolvidos no debate, que serão apresentados em seguida.

\subsection{Algodão Roundup Ready (RR) evento MON 1445: empresa Monsanto do Brasil}

O algodão RR foi modificado a partir da variedade comercial Coker 312 com o plasmídeo PVGHGT07 por meio do sistema Agrobacterium tumefaciens, com a inserção dos genes cp4 epsps, nptII, gox e aad. A transformação expressa a enzima CP4 EPSPS (CP4 5enolpiruvilshiquimato-3-fosfato sintase) proveniente de Agrobacterium sp. cepa CP4, a qual confere a resistência da linhagem ao herbicida glifosato. Também possui o gene marcador de seleção cp4 epsps, que confere resistência ao antibiótico canamicina (COMISSÃO TÉCNICA NACIONAL DE BIOSSEGURANÇA, 2008b).

Nas tabelas 2 e 3 abaixo, encontram-se o resumo dos pareceristas das subcomissões setoriais da CTNBio, assim com o parecer final da Comissão sobre o evento em questão que irão subsidiar as discussões a respeito do processo de deliberação sobre esta variedade transgênica, partindo dos aspectos ambientais, sociais e econômicos considerados pelos participantes. 
Tabela 2 - Pareceres das Subcomissões setoriais da CTNBio sobre o Algodão Roundup Ready (RR) evento MON 1445.

\begin{tabular}{|c|c|}
\hline $\begin{array}{c}\text { Subcomissões } \\
\text { Setoriais }\end{array}$ & Pareceres sobre o Relatório da Monsanto para o evento MON1445 \\
\hline $\begin{array}{l}\text { Área Vegetal/ } \\
\text { Ambiental } \\
\text { Relatores: } \\
\text { Francisco Aragão, } \\
\text { Luiz A. B. Castro, } \\
\text { Paulo Andrade e } \\
\text { Laércio Zambolim } \\
\text { (Membros da } \\
\text { CTNBio). Décio } \\
\text { Karam } \\
\text { Alexandre } \\
\text { C.B.Ferreira } \\
\text { hoc) }\end{array}$ & 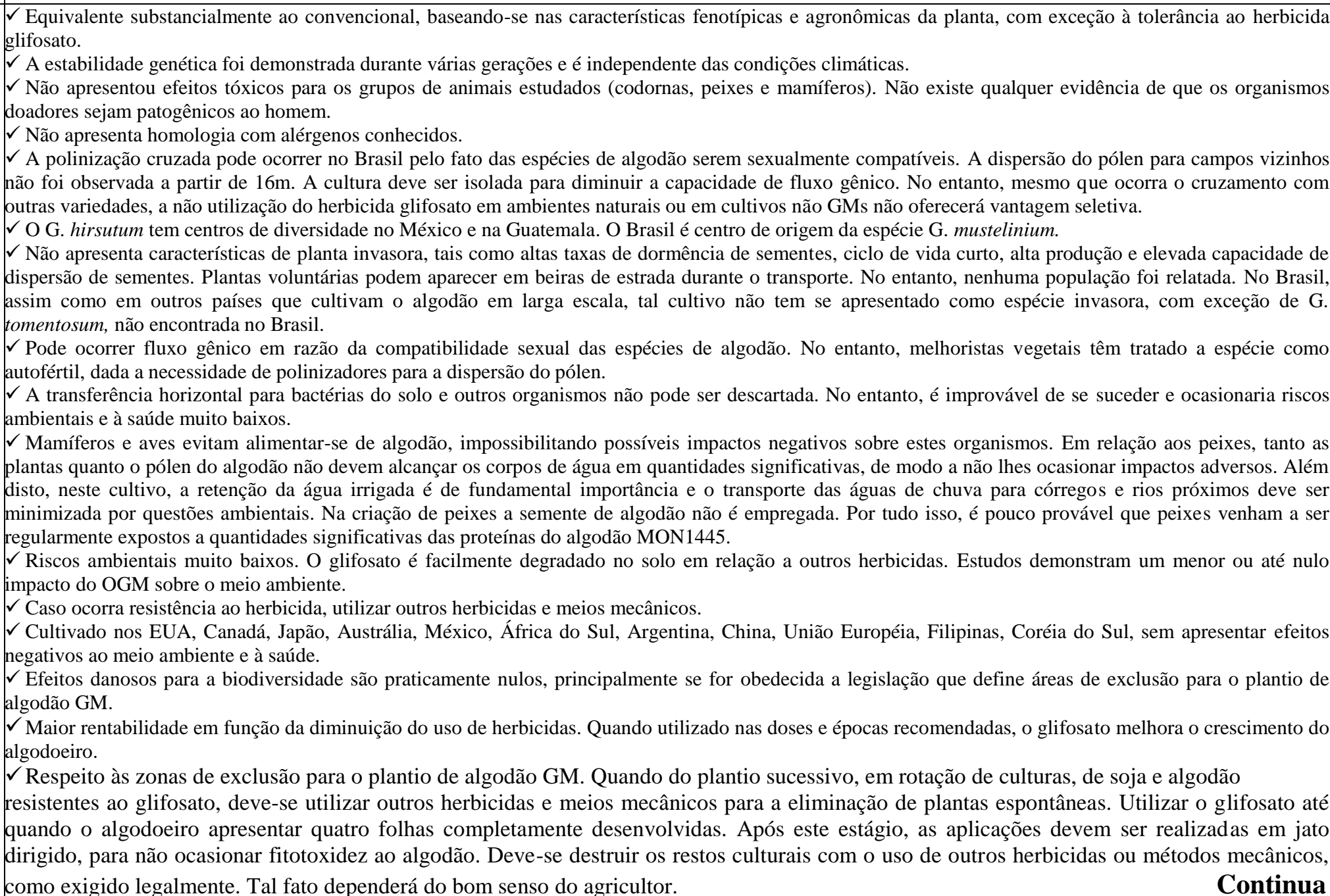 \\
\hline
\end{tabular}




\begin{tabular}{|c|c|}
\hline $\begin{array}{c}\text { Subcomissões } \\
\text { Setoriais }\end{array}$ & Pareceres sobre o Relatório da Monsanto para o evento MON1445 \\
\hline & $\begin{array}{l}\checkmark \text { Coexistência possível, desde que respeitadas as zonas de exclusão. } \\
\text { Parecer favorável, pois o evento é seguro ambientalmente e à saúde. }\end{array}$ \\
\hline $\begin{array}{lr}\text { Relator: } & \text { Paulo } \\
\text { Kageyama } & \\
\text { (Membro } & \text { da } \\
\text { CTNBio) } & \end{array}$ & 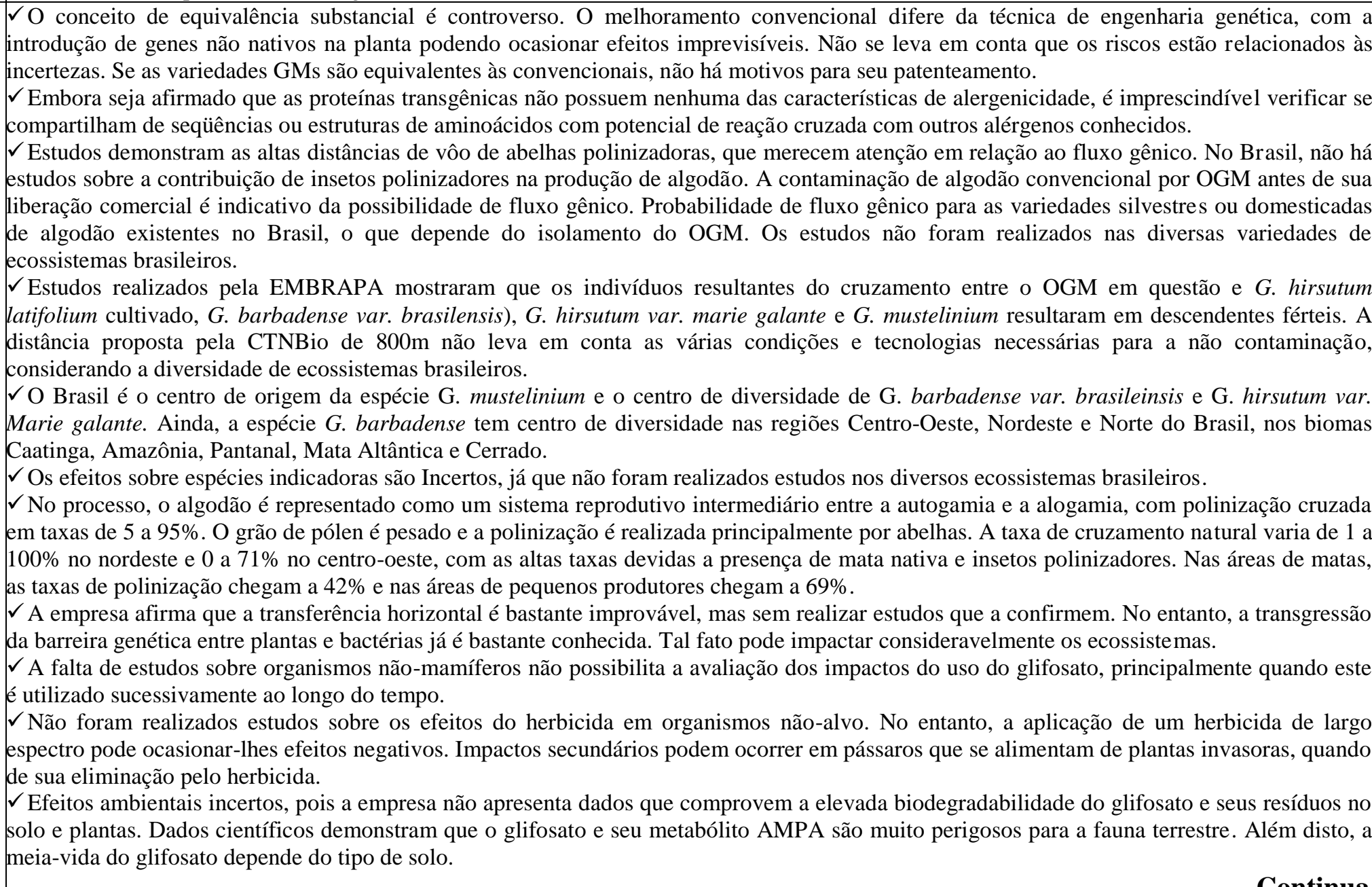 \\
\hline
\end{tabular}




\begin{tabular}{c|c}
\hline $\begin{array}{c}\text { Subcomissões } \\
\text { Setoriais }\end{array}$ & Pareceres sobre o Relatório da Monsanto para o evento MON1445 \\
\hline
\end{tabular}

$\checkmark$ Plantas invasoras podem desenvolver resistência ao glifosato se aplicado repetidamente em um longo intervalo de tempo. Estudos demonstram a aceleração em seu surgimento após a liberação de OGMs.

$\checkmark \mathrm{Na}$ Índia, a liberação do algodão GM levou a uma onda de suicídios por parte dos agricultores que o utlizaram, em razão de seu baixo rendimento, o que ocasionou aumento da pobreza, perda de terras e do acesso aos créditos rurais. Nos EUA, 2/3 dos 36 tipos de cultivos existentes estão contaminados com transgenes. Em alguns países em que houve a liberação em larga escala de OGMs resistentes ao glifosato, constatou-se aumento da resistência de plantas invasoras, tais como EUA, Brasil, Austrália, África do Sul, Argentina e Espanha.

$\checkmark$ Diversas falhas na documentação apresentada pela empresa, tais como:

- No recebimento do processo, faltaram referências bibliográficas que dificultaram a análise;

- Empresa não apresentou dados que confirmem a baixa toxicidade e alta biodegradabilidade do glifosato;

- Não realizou estudos de impacto ambiental para afirmar que o OGM e o uso sucessivo do herbicida não sejam potencialmente causadores de danos;

- Não realizou estudos sobre diversas espécies indicadoras;

- O surgimento de plantas invasoras no Brasil, EUA e Argentina após a utilização em larga escala e sucessiva de OGMs RR não foi mencionado;

- Não apresentou estudos sobre transferência horizontal de genes. O relatório da Monsanto apresenta contradições, tais como: 1) "Com a exceção da tolerância ao glifosato, as plantas de Algodão RR evento 1445 demonstraram equivalência em todas as características fenotípicas e agronômicas em relação ao padrão demonstrado pela linhagem parental convencional e/ou por outras variedades convencionais.". 2) "Em alguns locais observou algumas diferenças...como florescimento mais tardio, menor número de frutos e macho-fertilidade".

- Não são apresentadas referências bibliográficas na afirmação da empresa de que o evento reduz o número de herbicidas utilizados e o número de aplicações necessárias para o controle das plantas invasoras. O mesmo é dado pela afirmação de que no Brasil é previsto um impacto positivo com a liberação do algodão RR devido às vantagens mencionadas de redução do uso de agroquímicos.

$\checkmark$ A eliminação de plantas invasoras pode impactar as cadeias trófiças, com a eliminação do alimento aos organismos não-alvo. Efeitos negativos sobre a fauna (incluindo a microfauna do solo) em decorrência do herbicida não se encontram esclarecidos, mas devem ser considerados na análise de risco.

$\checkmark$ Preocupação com possíveis desvantagens econômicas, tais como:

- Aumento da pobreza e perda de terras, como vem ocorrendo na Índia. Aumento, pela Monsanto, de 16,67\% no valor da taxa que cobrará aos agricultores que plantarem suas sementes transgênicas RR na safra 2008/2009. Após dois anos de congelamento, os royalties cobrados subiram de R $\$ 0,30$ para $R \$ 0,35$ por quilo na compra de semente certificada. Exemplo do aumento no preço das sementes da soja RR no Brasil, sem consulta às organizações de agricultores, justificado pela Monsanto devido o fato de os agricultores multiplicarem sementes sem o pagamento das taxas de propriedade intelectual. Não foram apresentadas provas do maior rendimento do OGM em relação ao convencional. A ABRASEM solicitou à CTNBio a comercialização de algodão convencional apresentando $1 \%$ de contaminação pelo OGM antes de sua liberação, o que demonstra a existência de fluxo gênico. No caso da soja RR, houve no Brasil aumento da aplicação de glifosato em 95\%, contrariando a promessa da empresa quanto à diminuição de seu uso quando da liberação comercial do OGM.

Continua 


\begin{tabular}{|c|c|}
\hline $\begin{array}{c}\text { Subcomissões } \\
\text { Setoriais }\end{array}$ & Pareceres sobre o Relatório da Monsanto para o evento MON1445 \\
\hline & $\begin{array}{l}\text { Desde a liberação da soja RR, sua área cultivada aumentou em } 70,8 \% \text { no período de } 2000 \text { a } 2004 \text {, após a liberação comercial. O mesmo pode } \\
\text { acontecer com o evento analisado. } \\
\checkmark \text { Empresa deve apresentar dados qualitativos e quantitativos sobre o resíduo de glifosato na planta e efeitos de seus resíduos. Deve realizar } \\
\text { estudos de impacto ambiental nos ecossistemas brasileiros. O monitoramento pós-comercial deve ser realizado para a detecção de contaminação } \\
\text { das variedades não GM. É conhecido que o glifosato e seu metabólico AMPA são perigosos para a fauna terrestre, mas esses estudos não foram } \\
\text { apresentados. A biodegradabilidade do glifosato deve ser incluída na análise de riscos, considerando os diferentes tipos de solo. A empresa } \\
\text { deve realizar experimentos contínuos para avaliar a evolução do consumo do glifosato na tecnologia RR, tendo a soja GM como exemplo, já que } \\
\text { o aumento de seu uso foi confirmado após sua liberação comercial. Estudos demonstram distâncias de vôo do polinizador Bombus sp de até } \\
1750 \text { m a partir do ninho. Os estudos apresentados pela Monsanto se basearam em aspectos agronômicos e não nas relações ecológicas. } \\
\checkmark \text { Parecer contrário à liberação, em razão da ausência de argumentações cientificamente embasadas no relatório da Monsanto. O processo deve } \\
\text { ser revisto e a proposta novamente apresentada. }\end{array}$ \\
\hline $\begin{array}{l}\text { Saúde Humana e } \\
\text { Animal } \\
\text { Relatores: Anibal } \\
\text { Vercesi e } \\
\text { Marcelo Menossi } \\
\text { (Membros da } \\
\text { CTNBio) e José } \\
\text { Luiz (ad hoc) }\end{array}$ & 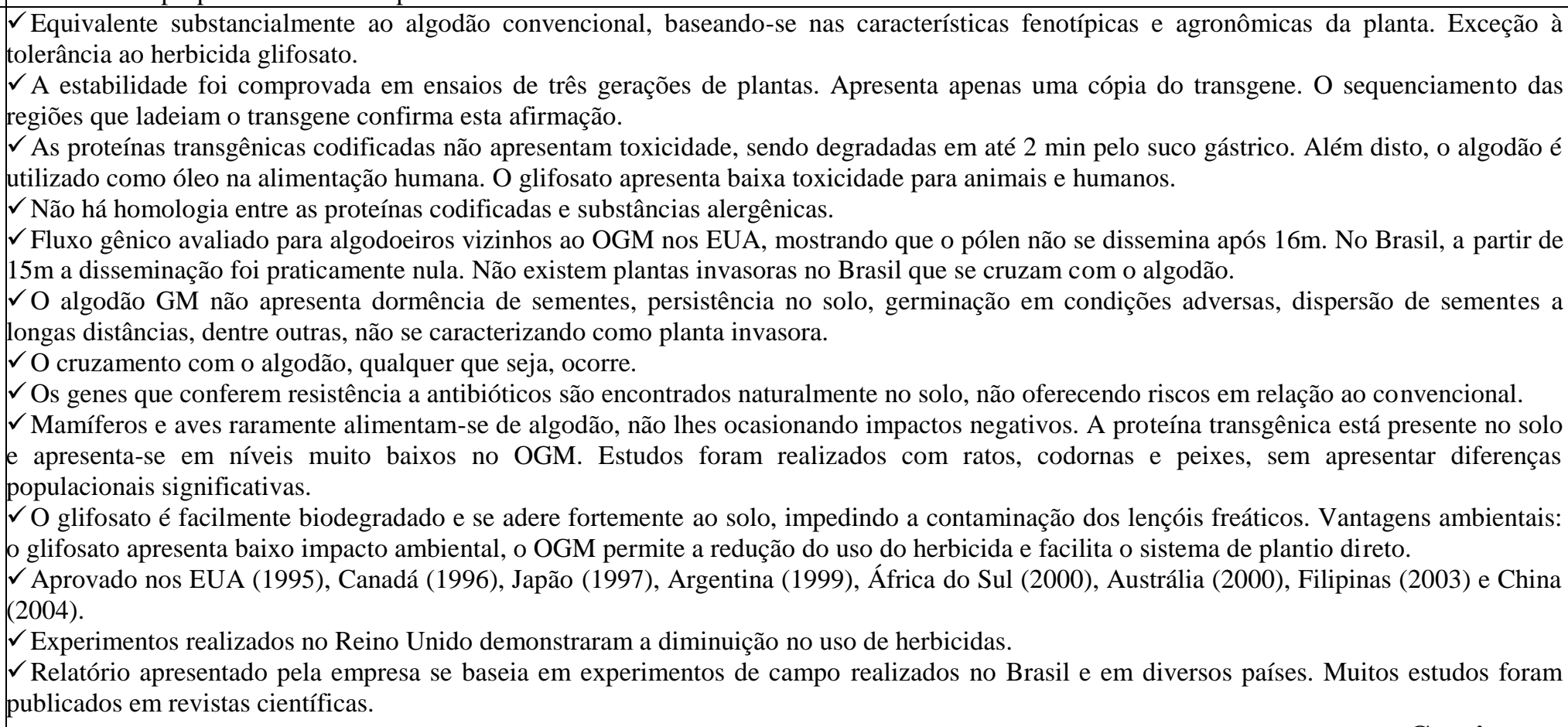 \\
\hline & Continua \\
\hline
\end{tabular}




\begin{tabular}{|c|c|}
\hline $\begin{array}{c}\text { Subcomissões } \\
\text { Setoriais }\end{array}$ & Pareceres sobre o Relatório da Monsanto para o evento MON1445 \\
\hline & $\begin{array}{l}\checkmark \text { Apresenta o mesmo rendimento em relação ao convencional, com a vantagem da diminuição dos custos de produção. No entanto, estudos } \\
\text { demonstram toxicidade se elevadas doses do herbicida forem utilizadas. } \\
\checkmark \text { Parecer Favorável. }\end{array}$ \\
\hline $\begin{array}{l}\text { Saúde humana e } \\
\text { animal } \\
\text { Relator: Victor } \\
\text { Augustus Marin } \\
\text { (ad hoc) }\end{array}$ & 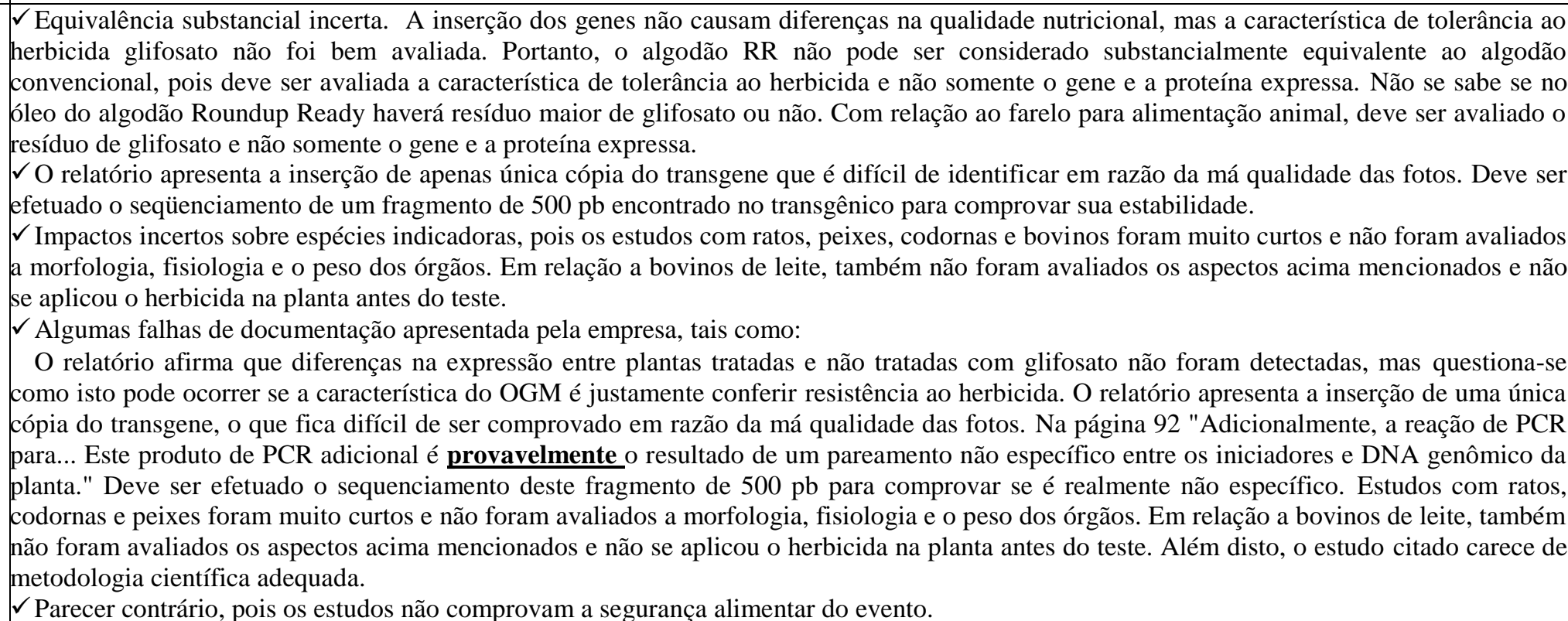 \\
\hline
\end{tabular}

Fonte: Andrade (2008); Aragão (2008); Barreto (2006); Ferreira (2008); Kageyama (2008); Karam (2008); Luiz (2008); Marin (2008); Menossi (2007); Vercesi (2007); Zambolim (2008). 
Tabela 3 - Parecer final da CTNBIO sobre o Algodão Roundup Ready (RR) evento MON 1445.

\begin{tabular}{|c|c|}
\hline $\begin{array}{l}\text { Critérios para a } \\
\text { Análise de Risco }\end{array}$ & Parecer Final da CTNBio \\
\hline $\begin{array}{c}\text { Equivalente } \\
\text { substancialmente }\end{array}$ & $\begin{array}{l}\text { Sim. Com exceção da tolerância ao herbicida glifosato o agodão RR demonstra características fenotípicas e agronômicas equivalentes às } \\
\text { linhagens convencionais. }\end{array}$ \\
\hline Estabilidade genética & $\begin{array}{l}\text { Sim. As análises moleculareso mostraram que o transgene foi parcialmente inserido em um único lócus do genoma do algodão. A estabilidade } \\
\text { genética do evento MON } 1445 \text { foi determinada pelo padrão de estabilidade hereditária, pela integridade do DNA inserido e pela estabilidade } \\
\text { do fenótipo em várias condições ambientais determinadas em várias gerações de linhagens obtidas por retrocruzamento com cultivares elite. }\end{array}$ \\
\hline Potencial de toxicidade & $\begin{array}{l}\text { Não existe qualquer evidência de que os organismos doadores dos genes inseridos sejam patogênicos ao homem. Além disto, as proteínas } \\
\text { codificadas são facilmente degradadas no sistema digestório. Estudos de toxicidade oral foram realizados com camundongos (com proteína } \\
\text { isolada), sem efeitos negativos. Não foram observados sinais clínicos anormais em nenhum dos animais durante o estudo, de modo que não } \\
\text { houve diferença estatística significativa em peso corporal, peso corporal cumulativo ou consumo de alimentos entre os tratamentos e os grupos } \\
\text { de controle. }\end{array}$ \\
\hline \multicolumn{2}{|r|}{ D } \\
\hline Fluxo gênico & $\begin{array}{l}\text { A introgressão de um transgene para plantas silvestres de algodão só poderia ocorrer se este conferisse uma forte vantagem seletiva, superior às } \\
\text { desvantagens conferidas pelos alelos que estão geneticamente ligados ao transgene. No entanto, a característica de tolerância a herbicida é } \\
\text { reconhecida como não sendo capaz de dotar os genótipos receptores de qualquer vantagem adaptativa fora de áreas agrícolas, uma vez que fora } \\
\text { destas áreas os potenciais genótipos silvestres receptores não sofrem ação da pressão seletiva do herbicida e, portanto, a eventual polinização } \\
\text { destes genótipos não resulta em introgressão gênica. }\end{array}$ \\
\hline $\begin{array}{l}\text { Centros de origem da } \\
\text { espécie (nativa ou não) }\end{array}$ & $\begin{array}{l}\text { O gênero Gossypium compreende atualmente } 50 \text { espécies bastante diversas, oriundas da América, África, Ásia e da Austrália. Os centros de } \\
\text { origem de G. hirsutum encontram-se no México e na Guatemala, enquanto os de G. barbadense, no Peru e na Bolívia. A única espécie nativa } \\
\text { do Brasil é G. mustelinum, com distribuição natural restrita ao semi-árido nordestino. Populações são conhecidas apenas nos estados da Bahia e } \\
\text { do Rio Grande do Norte, em municípios que não produzem algodão herbáceo. Pequena quantidade de algodoeiros arbóreos, principalmente } \\
\text { híbridos inter-raciais de fibra branca e colorida produzidos pelo programa de melhoramento da Embrapa ainda são cultivados. Tais populações } \\
\text { estão geograficamente isoladas de lavouras de algodoeiro herbáceo e bem representadas nos bancos de germoplasma da Embrapa. }\end{array}$ \\
\hline $\begin{array}{l}\text { Capacidade reprodutiva e } \\
\text { de dispersão fora da área } \\
\text { de cultivo }\end{array}$ & $\begin{array}{l}\text { O algodoeiro (G. hirsutum) não tem mostrado potencial invasor no Brasil, assim como nos demais países do mundo onde é regularmente } \\
\text { cultivado em grandes extensões. Nas margens das rodovias onde são transportados caroços e outros produtos de algodão, podem aparecer } \\
\text { eventualmente plantas que se estabelecem apenas nos locais onde há, natural ou artificialmente, acúmulo de umidade. Não se nota, contudo, } \\
\text { qualquer avanço destas plantas para outras áreas. Adicionalmente, dentro do gênero Gossypium não há relatos de qualquer potencial como }\end{array}$ \\
\hline & planta invasora, exceto no caso de G. tomentosum, que não existe no Brasil Continua \\
\hline
\end{tabular}


Critérios para a

Análise de Risco

Freqüência com que

ocorre o cruzamento do

organismo parental do

OGM, dentro da mesma

espécie e com espécies

sexualmente compatíveis

Transferência horizontal e vertical.

Impactos sobre organismos alvo e nãoalvo

\section{Parecer Final da CTNBio}

Além do algodoeiro herbáceo, três outros algodoeiros ocorrem no Brasi, sexualmente compatíveis com os cultivares. O algodão é usualmente apresentado como uma cultura de polinização cruzada parcial, embora muitos melhoristas considerem a planta como completamente autofértil e autopolinizadora, exceto por polinização cruzada, por meio de insetos polinizadores. O algodão apresenta taxas de polinização cruzada entre $5 \%$ e $95 \%$. A autopolinização é a forma de hibridação que ocorre preferencialmente na cultura do algodão, embora o cruzamento natural possa ocorrer.

A transferência horizontal de genes é um evento possível, porém extremamente raro entre um eucarioto e um procarioto, ou mesmo entre eucariotos, quando entre eles não há nenhuma proximidade evolutiva. Apenas entre microrganismos a transferência horizontal pode ocorrer, embora ainda assim em taxas muito baixas. Os microrganismos que, por transferência horizontal de genes ganhassem uma cópia do gene $c p 4$ epsps, teriam a capacidade de sintetizar aminoácidos aromáticos e outros compostos aromáticos, mesmo na presença de glifosato. Ocorre, contudo, que a capacidade de degradar o glifosato está amplamente distribuída na comunidade microbiana, de forma que este novo caráter em nada contribuiria para a manutenção do gene transferido. Ademais, é importante lembrar que o gene epsps é ubíquo e a flora microbiana já é, naturalmente, tolerante ao glifosato.

Da mesma forma, microrganismos que recebessem o gene npt-II poderiam se tornar resistentes a neomicina e outros antibióticos relacionados. Entretanto, como discutido anteriormente, não haveria pressão seletiva sobre estes microrganismos, já que estes antibióticos não são empregados nos plantios comerciais. Também não há qualquer relato de mudança da flora microbiana do solo associada à expressão destes genes. A transferência de outros elementos da construção para a flora microbiana, como o promotor CaMV, poderia causar algum efeito, mas nada disso parece acontecer.

A probabilidade de transferência de genes entre organismos superiores filogeneticamente não relacionados é extremamente remota e a transferência entre uma planta e um animal é ainda mais improvável. Para o gene cp4-epsps, o ganho de tolerância a herbicida não daria qualquer vantagem ou desvantagem ao animal, seja ele vertebrado ou invertebrado. O mesmo ocorre para o gene npt-II. A transferência de sequencias regulatórias poderia ter efeitos imprevisíveis, mas elas estão presentes numa enorme gama de alimentos (assim como o gene epsps).

A maioria dos mamíferos, devido à presença do gossipol e de outros componentes dos tecidos da planta, tornando o uso do caroço do algodão limitado na pecuária. Além disso, nos campos, a semente do algodão está coberta pela pluma, o que a torna pouco atraente para aves. Nos dois casos, portanto, é pouco provável que animais silvestres venham a se alimentar de quantidades significativas de sementes de algodão ou de outras partes da planta. Na criação de peixes, a semente de algodão não é empregada. Não se espera que plantas de algodão e pólen alcancem rios e outras coleções de água em quantidades significativas para causar impactos, sendo vital a retenção da água de irrigação nos campos e necessária a minimização do escoamento das águas de chuva para corpos de água por razões ambientais. Por tudo isso, é pouco provável que peixes venham a ser regularmente expostos a quantidades significativas das proteínas recombinantes do algodão. Ademais, a proteína EPSPS é encontrada na natureza, estando presente em todas as plantas e em um grande número de microrganismos. Por isso, todos os seres vivos que se alimentam de plantas e microrganismos já são expostos às tais proteínas. Os invertebrados podem entrar em contato com as proteínas recombinantes consumindo o algodoeiro ou pela predação de insetos que dele se alimentaram. A exposição será maior para aqueles que se alimentam diretamente de folhas e outros tecidos.
Continua 
Polinizadores e consumidores de pólen podem ser expostos a quantidades pequenas de proteínas recombinantes, já que a expressão destas proteínas no pólen é muito inferior a dos demais tecidos, o que está amplamente documentado no processo. Uma vez que as proteínas recombinantes são consumidas, não parece haver qualquer efeito sobre os insetos: embora não haja trabalhos publicados sobre isso. $\mathrm{O}$ algodão MON 1445 foi testado tanto nos EUA como no Brasil quanto à susceptibilidade a várias pragas agrícolas e não houve qualquer diferença entre a linhagem transgênica e a parental. A proteína NPT-II, por sua vez, não possui qualquer propriedade que a distinga da mesma enzima em microrganismos. As duas proteínas transgênicas estão na natureza, amplamente distribuídas entre os microrganismos. Assim, a expressão destas proteínas na planta de algodão não deve ter qualquer efeito tóxico em invertebrados.

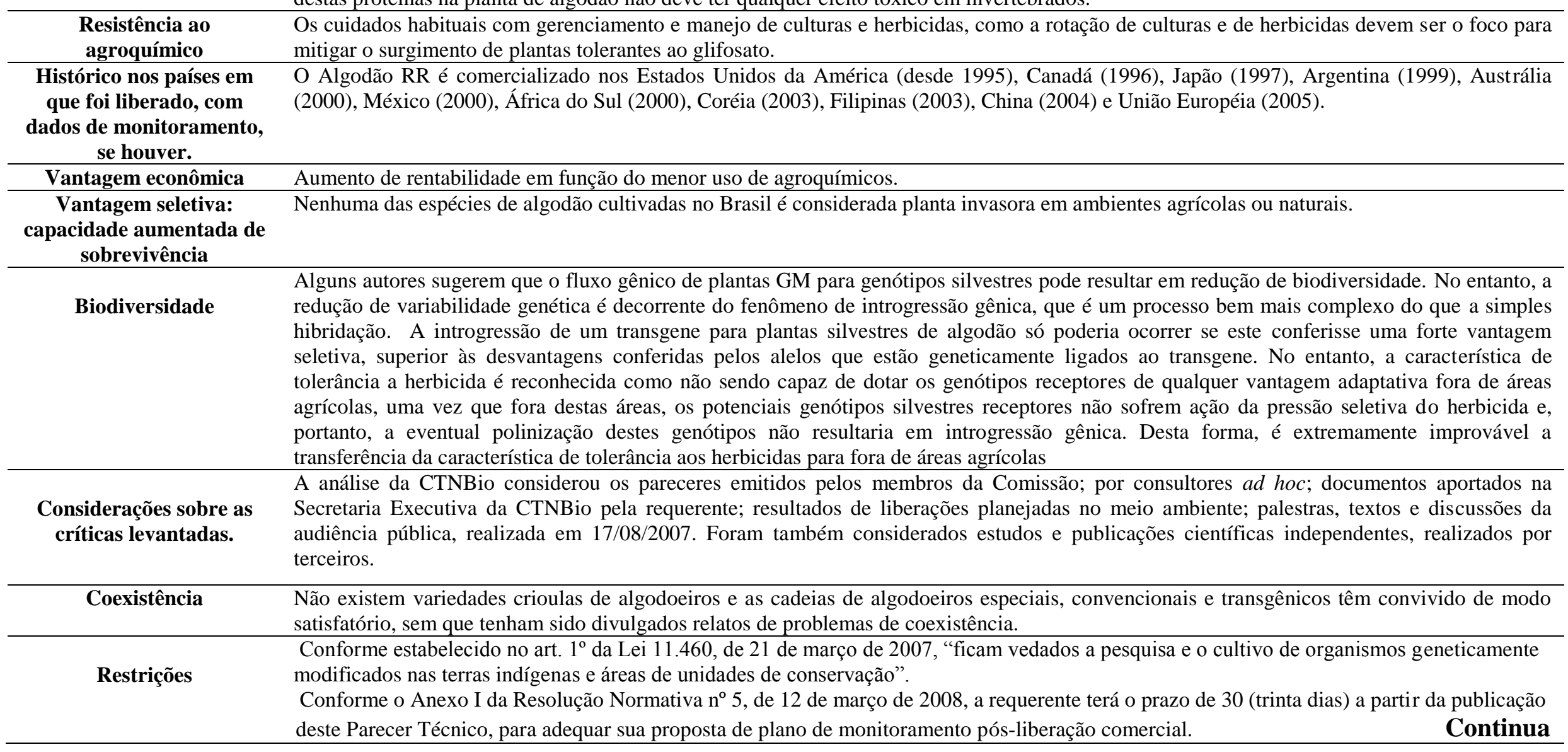




\section{Critérios para a}

Análise de Risco

\section{Parecer Final da CTNBio}

A tecnologia Roundup Ready evento MON 1445 mostrou-se passível de ser utilizada sob todas as práticas agrícolas comumente utilizadas nas

Particularidades regionais diversas regiões e condições, seja disponibilidade de insumos, mão-de-obra, dentre outros, utilizados na cultura do algodão. Adicionalmente, essa tecnologia poderá permitir maior sucesso no uso de plantio direto.

Parecer Favorável, pois a CTNBio considerou que o pedido atende às normas e à legislação pertinente que visam garantir a biossegurança do meio ambiente, agricultura, saúde humana e animal.

Fonte: Modificado de COMISSÃO TÉCNICA NACIONAL DE BIOSSEGURANÇA (2008b)

Observa-se, em uma análise comparativa entre os pareceres das Subcomissões Setoriais e o parecer final da CTNBio que não foram consideradas os apontamentos e sugestões do representante do Ministério do Meio Ambiente, Paulo Kageyama e de Marcos Vinícius, da Subcomissão Vegetal, mesmo que pertinentes. Nestas situações, a CTNBio poderia solicitar ao proponente esclarecimentos sobre as dúvidas abordadas, de acordo com a Lei de Biossegurança. No entanto, as evidências apontam que a Comissão não as tenha remetido a Monsanto. 


\section{$\checkmark$ Aspectos abordados na audiência pública sobre o algodão MON 1445.}

$\mathrm{Na}$ audiência pública realizada em 17 de agosto de 2007, seis eventos foram submetidos à discussão: o algodão Liberty Link (LL), evento LL Cotton 25 e algodão LL, ambos resistentes ao herbicida glufosinato de amônio e desenvolvidos pela Bayer; algodão RR, evento MON1445, tolerante ao herbicida glifosato e algodão Bolgard (Bt), evento MON15985 tolerante aos insetos da Ordem Lepidoptera, ambos da Monsanto, além do algodão Widestrike, evento 2813006, com dupla resistência, tanto ao glifosato quanto aos insetos, desenvolvido pela Dow Agroscience. Como todos os eventos analisados possuem características comuns, pertencentes ao mesmo cultivo e com transgenes que conferem características de resistência a herbicidas ou insetos, muitos comentários apresentados pelos participantes caberão aos diversos eventos abordados.

A audiência foi realizada em Brasília, no Auditório Petrônio Portela, dependência do Congresso Nacional, sendo presidida pelo presidente da CTNBio, Dr.Walter Colli e estruturada da seguinte forma: exposições orais no período da manhã, compreendendo representantes das bioindústrias desenvolvedoras das PGMs, membros da Academia, de ONGs e do Ministério Público, com debate público no período vespertino. O anfiteatro escolhido tinha capacidade para 490 a 500 pessoas, incompatível com a demanda de inscritos, que fora de 943 pessoas. Deste modo, diversos interessados no assunto não puderam participar do evento. A este respeito, cabe transcrever o posicionamento do presidente da CTNBio:

[...] desta vez, inesperadamente, foram 943 inscritos e nós já havíamos acertado este anfiteatro que, ainda bem é grande, mas só cabem 490, 500 pessoas, então algumas pessoas ficarão de fora, infelizmente, mas não se pode fazer nada. Eu não pensei em contratar o Estádio Mané Garrincha para fazer a audiência de algodão, infelizmente.

Colli apud COMISSÃO TÉCNICA NACIONAL DE BIOSSEGURANÇA (2007)

Os representantes das bioindústrias das PGMs, membros da Academia especializados em biotecnologia, melhoramento vegetal e nutrição animal, representantes de organizações de agricultores (em sua maioria de grandes produtores, mas também de médios e pequenos produtores) demonstraram as vantagens sociais, ambientais e econômicas da liberação do algodão GM, fundamentando-se em estudos acadêmicos, produzidos pelas bioindústrias e 
órgãos governamentais de países que liberaram PGMs em larga escala. Os argumentos por eles apresentados foram (COMISSÃO TÉCNICA NACIONAL DE BIOSSEGURANÇA, 2007):

- A estabilidade dos transgenes inseridos nas gerações analisadas (geralmente quatro) e sua cópia única no organismo receptor comprovadas;

- A existência na natureza dos genes inseridos nas plantas receptoras (microorganismos presentes no solo, no caso do gene Bt), conferindo-lhes inocuidade à saúde humana/outros animais/vegetais.

- A inocuidade das proteínas codificadas a organismos não-alvo, incluindo os humanos (não lhes conferindo toxicidade e alergenicidade);

- O baixo risco de fluxo gênico e introgressão genética nas populações receptoras;

- A equivalência substancial das PGMs com suas contrapartes convencionais;

- A possibilidade de coexistência entre as variedades GMs, convencionais e orgânicas;

- As vantagens no controle dos organismos alvo (plantas invasoras e pragas, no caso, espécies da Ordem Lepidoptera);

- A sustentabilidade ambiental conferida pelas PGMs em função da diminuição da aplicação de agrotóxicos. Os insetos não alvo se beneficiariam da tecnologia por este motivo. Também haveria mais segurança quanto à saúde do trabalhador rural, como observado na China, em que os casos de intoxicação de trabalhadores pela exposição aos agrotóxicos diminuíram desde a introdução do algodão transgênico;

- A redução do uso de agroquímicos diminui a contaminação dos corpos de água e do solo, a qual seria outra vantagem ambiental;

- A sustentabilidade econômica tanto aos pequenos e grandes produtores rurais no cultivo das PGMs, em razão do aumento da produtividade agrícola (menores gastos com insumos e mãode-obra). A utilização em larga escala destes organismos em diversos países, tanto desenvolvidos quanto em desenvolvimento e o aumento da produtividade agrícola apresentada foi apontada por diversos participantes. Por exemplo, houve aumento de $30 \%$ da produtividade agrícola e redução de $80 \%$ da aplicação de inseticidas na Índia após a adoção do algodão $\mathrm{Bt}$;

- As vantagens econômicas para o país com o aumento das exportações dos cultivos, como decorrência de sua maior produtividade e do aumento da competitividade com o mercado internacional de transgênicos. Externou-se preocupação com a elevada competitividade da Índia no mercado internacional de algodão; 
- A resistência à toxina $\mathrm{Bt}$ e aos herbicidas adotados com o pacote tecnológico é considerada inevitável por diversos de seus defensores. No entanto, a adoção de zonas de refúgio e a rotação de culturas nas áreas de cultivo são consideradas suficientes para seu controle. Um dos participantes argumentou que novas tecnologias possam ser criadas para sanar os problemas advindos da resistência;

- Não haveria dependência dos agricultores às empresas detentoras das sementes, pois estes poderiam utilizar novamente o sistema convencional ou alternativo no caso de surgir desvantagens em sua utilização. Os representantes da EMBRAPA reivindicaram, como forma de reduzir os custos de produção aumentados com a compra de sementes patenteadas, o investimento estatal em institutos de pesquisa nacionais para o desenvolvimento de PGMs, o que impediria a dependência do agricultor em relação às multinacionais que lideram a comercialização de transgênicos. Segundo alguns participantes, o respeito ao direito do agricultor em adotar o sistema de cultivo que melhor lhe prouver seria garantido com a introdução do algodão transgênico. Neste sentido, cabe a citação de um debatedor:

Se daqui uns dias for conveniente do ponto de vista ambiental, econômico e social voltar à cultura orgânica nós voltaremos também, se daqui uns dias resolvermos brigar com as multinacionais com relação aos custos, brigaremos também. Não nos pode ser tirado esse direito. O direito que nós temos de optar por aquilo que fazemos e nisso nós exigimos respeito, nós não somos tão burros assim.

\section{Bortolozo apud COMISSÃO TÉCNICA NACIONAL DE BIOSSEGURANÇA (2007)}

- Alguns atores sociais apontaram a vantagem econômica em se reduzir o uso de maquinários agrícolas devido às maiores facilidades no manejo de plantas invasoras e também pela diminuição da mão-de-obra.

Alguns dos apresentadores que argumentaram favoravelmente à liberação comercial das PGMs apontaram alguns estudos científicos que comprovam a segurança destes organismos, a fim de substanciar suas opiniões.

Já os apresentadores e demais participantes do debate que externaram preocupações quanto à liberação comercial das PGMs, pertencentes ao meio acadêmico (especialistas em meio ambiente, geneticistas e melhoristas), representantes de ONGs (ambientais, de pequenos agricultores e de defesa dos direitos do consumidor) e promotores do Ministério Público apresentaram os seguintes argumentos, que também se substanciaram em estudos científicos, relatórios governamentais e de ONGs, além da constatação direta dos agricultores em 
condições de campo. Os argumentos foram os seguintes (COMISSÃO TÉCNICA NACIONAL DE BIOSSEGURANÇA, 2007):

- Consequências negativas ou incertas da utilização dos OGMs para uma agricultura sustentável ambiental, econômica e social, considerada uma tendência mundial. Para tanto, este modelo deve ter como princípios o amparo social (geração de emprego e renda, segurança alimentar), preservação ambiental e melhoria da qualidade de vida humana e animal. Alguns atores sociais apontaram as desvantagens dos OGMs em preencher todos os requisitos necessários para uma agricultura sustentável, tanto do ponto de vista econômico quanto ético e ambiental;

- A desvantagem econômica em função de sua menor produtividade. Esta seria dada pela maior mobilização energética do cultivo (especialmente no caso em que exista piramidação genética) para a produção de proteínas extras. Neste sentido, as PGMs seriam até 5\% menos produtivas do que as plantas convencionais. Apontou-se que, nos EUA, a maior produtividade dos OGMs é um reflexo do baixo valor dos agrotóxicos e dos subsídios agrícolas;

- O surgimento de resistência ao inseticida por parte dos organismos alvo e ao herbicida, fato considerado inevitável até mesmo pelos defensores da tecnologia, em razão da pressão de seleção. Foram exemplificadas situações de resistência em países que cultivam PGMs em larga escala, tais como a Argentina, em que 15 plantas invasoras tornaram-se resistentes ao glifosato. Na Índia, diversos suicídios ocorreram após a introdução do algodão Bt, em função da perda de produtividade do cultivo com o surgimento de pragas resistentes. Na China também se constatou resistência em cultivos GMs, com consequente aumento na aplicação de agrotóxicos, elevada mortalidade de inimigos naturais e intoxicação de animais;

- Aumento do uso dos herbicidas incluídos nos pacotes tecnológicos. No Brasil, por exemplo, a dose aplicada de glifosato sofreu um aumento de 50 vezes com a adoção da soja RR;

- A transgenia foi criada com o pretexto de se vender mais agrotóxico. Apontou-se um faturamento de 26 bilhões de reais pelas multinacionais produtoras de PGMs;

- O gene Bt não se restringe a apenas alguns tecidos da planta, podendo afetar animais nãoalvo. Além disto, há uma diferença entre o Bt produzido pela planta e aquele utilizado nas formulações de agrotóxicos. Enquanto estes se apresentam na forma de cristais (não ativos), ativando-se apenas no interior de determinados lepidópteros que possuem receptores para a proteína, o Bt produzido pela PGM encontra-se na forma ativa, afetando qualquer lepidóptero que entre em contato com a toxina, inclusive insetos benéficos, tais como abelhas polinizadoras; 
- Coexistência impossível entre PGMs e variedades não GMs. A contaminação de cultivos não geneticamente modificados pelos transgenes das PGMs foi observada em 39 países e chegou a 15 ou $20 \%$ da produção. No Brasil, a contaminação da soja orgânica pela soja RR da Monsanto vem ocorrendo. Como forma de ilustrar a preocupação com a coexistência, cita-se a fala de representante da ONG Terra de Direitos:

Infelizmente a discussão sobre a questão da coexistência, no caso do milho foi feita por uma decisão judicial, primeiro a Comissão liberou o milho, foi publicado o parecer e tudo isso. Depois se começou a discutir as normas de coexistência e as normas de monitoramento. Isso tem que ser repensado. Eu acho que todo mundo concorda aqui, tem que ser estabelecidas normas para garantir a coexistência.

Reis apud COMISSÃO TÉCNICA NACIONAL DE BIOSSEGURANÇA (2007)

- Possibilidade de transferência dos genes marcadores resistentes a antibióticos para o ser humano e demais animais;

- Os efeitos da toxina Bt não atingem outras pragas importantes na cultura do algodão que não sejam lepidópteros, tais como insetos sugadores;

- A dependência dos agricultores pelas empresas produtoras de PGMs, em sua grande maioria multinacionais. Os custos de produção chegam a aumentar 50\%, em função dos gastos elevados com a compra das sementes. Haveria dependência do agricultor neste sentido, liquidando com a prática milenar de armazenamento e troca de sementes;

- Alguns estudos demonstraram impactos negativos de algodão GM com toxina Bt sob bactérias fixadoras de nitrogênio;

- Há controvérsias quanto ao potencial de alergenicidade de PGMs em humanos e demais animais, em razão de possíveis efeitos pleiotrópicos. Um caso comprovado de alergia em humanos se deu com o consumo de tomate transgênico nos EUA;

- No caso do algodão Bolgard (Bt), os órgãos governamentais de fiscalização apenas apresentaram suas normas de ação em 2006, após a liberação da PGM;

- Os condicionantes da CTNBio para a liberação do algodão Bt, tais como a eliminação das soqueiras, o respeito às zonas de refúgio e de exclusão do plantio não estão sendo devidamente fiscalizados;

- A Portaria 21 do MAPA desconsiderou a recomendação da EMBRAPA para impedir transporte de sementes de algodão Bt nas áreas de exclusão de plantio. O MAPA também não definiu a época de plantio do algodão $\mathrm{Bt}$, a fim de manejar uma possível resistência ao 
agrotóxico. Deste modo, demonstra-se a desarticulação entre os órgãos que compõem o sistema de biossegurança no país;

- Falta de estudos de impactos ambientais nos diversos ecossistemas brasileiros para a detecção de riscos, já que as condições ambientais são determinantes em sua análise. Diversos participantes levantaram a necessidade destes estudos como imperativos para a análise dos pedidos de liberação de PGMs;

- Não há monitoramento pós-comercial no Brasil e, portanto, não se podem determinar novas zonas de exclusão, se forem observados impactos negativos. Mesmo representantes de órgãos governamentais favoráveis à liberação do algodão transgênico, como a EMBRAPA, abordaram o monitoramento como indispensável à biossegurança. Tal órgão também levantou a necessidade de isolamento espacial do algodão GM e o respeito às zonas de exclusão e de refúgio para que sejam manejadas a resistência dos organismos alvo e a coexistência com os demais sistemas de cultivo. Um dos participantes questionou a inexistência de plano de monitoramento para o algodão GM e de normas para a coexistência;

- As liberações ambientais planejadas realizadas pelos proponentes destinam-se, em sua maioria, a avaliar o desempenho agronômico dos cultivos GM. No caso do milho LL da Bayer, por exemplo, solicitou-se 19 pedidos, sendo apenas 5 objetivados a analisar seu comportamento ambiental em dois municípios brasileiros. No caso do algodão Widestrike, foram conduzidas 17 liberações planejadas, sendo 12 referentes à análise agronômica, 3 aos efeitos sobre insetos não alvo e 2 sobre a codificação das proteínas transgênicas nos diversos tecidos das plantas, sem que nenhum parecer tenha sido concluído pela CTNBio. A realização dos estudos em curto intervalo de tempo, em poucas localidades e com o propósito de avaliar os aspectos agronômicos dos cultivos foram bastante criticados por alguns participantes, que os consideram insuficientes para a avaliação de biossegurança;

- Questionou-se a ausência de resolução normativa para os procedimentos de análise de risco de liberações planejadas e sua articulação com a liberação comercial. Estes não deveriam também ser realizados somente pelas empresas e seus pesquisadores contratados;

- Uma avaliação de riscos ambientais, com a utilização de espécies indicadoras das funções ecológicas do agroecossistema (polinizadores, decompositores, fixadores de nitrogênio) deveria ser efetuada;

- Na Índia, constatou-se uma produtividade decrescente do algodão, após a introdução do cultivo Bt. Impactos negativos sobre o solo e a invasão da praga Helicovar parmiguera ou broca americana no algodão híbrido foram observados. Outros cultivos não germinaram em áreas anteriormente cultivadas com algodão Bolgard; 
- Membros do Ministério Público externaram suas inquietações quanto ao atendimento do princípio da precaução nas avaliações de biossegurança de PGMs, presente na Convenção sobre Biodiversidade, no Protocolo de Cartagena, na Política Nacional de Meio Ambiente, Lei de Crimes Ambientais, dentre outras. Nas palavras da promotora do MPF Maria Soares Cordiolli:

[...] primeiro: O Conselho Nacional de Biossegurança já se defrontou, já deliberou sobre o princípio da precaução? Segundo: ele teria que estabelecer diretrizes e normas a serem seguidas pelos órgãos de fiscalização a serem seguidos pela CTNBio. No momento não dispomos dessa política nacional que deveria ser feita pelo Conselho Nacional de Biossegurança [..]. Esse Conselho também, lamentavelmente, não vem se articulando com o Sistema Nacional de Biossegurança do qual ele é parte, não se verifica uma articulação do Conselho Nacional de Biossegurança com a CTNBio, com a Comissão Nacional de Biodiversidade que também deve apresentar planos, projetos para a implementação das medidas de biossegurança. Esse Conselho também não se articula com a sociedade porque não vimos o que o Conselho está fazendo. E vamos agora à CTNBio. A CTNBio já deliberou sobre o princípio da precaução? Quais as certezas relevantes para a saúde e para o meio ambiente? A CTNBio já discutiu sobre o estudo de impacto ambiental? A nós nos parece que essa Comissão despreza esse instrumento. As avaliações de risco, ao nosso sentir, padecem de um aprofundamento da aplicação desse princípio da precaução. A CTNBio não editou normas para a liberação comercial [...]. A CTNBio somente ontem deliberou sobre as normas de monitoramento e coexistência [...]. A CTNBio não se articula com os órgãos de fiscalização para identificação de subsídios para fazer essas regras de monitoramento, para fazer essas regras de coexistência, para fazer estudos de impacto ambiental, para fazer análise de risco [...]. Os órgãos de fiscalização não editaram regras próprias para cumprir, para assegurar o princípio da precaução [...]. A CTNBio e os órgãos de fiscalização não editaram normas para assegurar o cumprimento do Protocolo de Cartagena em relação à questão do transporte da importação de alimentos geneticamente modificados. O Brasil está cumprindo o princípio da precaução? As deficiências da gestão administrativa da CTNBio são visíveis [...]. O sistema de formação de biossegurança não foi implementado, o consumidor não tem informações, a rotulagem é prevista na Lei de Biossegurança e até hoje não está implementada [...]. No Brasil o princípio da precaução e isso é grave, o princípio da precaução não é só princípio, é crime, ele está previsto expressamente na Lei de Crimes Ambientais no art. 54, § $3^{\circ}$ da Lei de Crimes Ambientais [...]. Fica essa questão: o Brasil cumpre o princípio da precaução? Não cumpre o princípio da precaução.

Cordiolli apud COMISSÃO TÉCNICA NACIONAL DE BIOSSEGURANÇA (2007)

- Com relação às zonas de exclusão para o algodão Bt, questionou-se a falta de consideração a respeito dos cultivos agroecológicos em sua delimitação, com a ameaça da perda da certificação destes produtos como orgânicos no caso de uma possível contaminação por 
transgenes. Tal fato compremete a permanência de um setor de mercado importante para o país e pequenos produtores, os quais inclusive vendem seus produtos para outros países, tais como a França;

- Diversos participantes levantaram a necessidade de se incluir todo o semi-árido brasileiro na zona de exclusão do algodão Bt, em função da existência de espécies nativas em toda a região nordeste. A polinização do cultivo por abelhas do gênero Apis sp pode comprometer sua permanência. Estudos realizados pelo grupo GMO ERA levantaram a probabilidade deste risco;

- Questionou-se a composição da CTNBio, formada em sua maioria por especialistas em biologia molecular que inclusive representam subcomissões ambientais. Também criticou-se o fato de as reuniões da CTNBio serem fechadas, podendo participar como ouvintes ou consultores apenas os cidadãos convidados ou que tiverem sua solicitação atendida pela Comissão. De acordo com Cordiolli, este fato fere os princípios constitucionais da publicidade e da informação;

- Levantaram-se críticas pelo fato de as empresas produtoras de agrotóxicos serem as proponentes de uma tecnologia que alardeiam como ambientalmente sustentável. Neste sentido, um dos representantes da Bayer assim argumentou:

Vocês imaginam o quanto de evolução nós tivemos na metodologia científica nesses anos. Com certeza, na época que muitos desses inseticidas que causam dano e que não deveriam ser submetidos aos homens, o pessoal não tinha conhecimento desses efeitos. Hoje com a preocupação que existe da sociedade com legislações específicas tratando de proteção ao homem, cada vez mais quem está interessado em gerar eventos e biotecnologia ele é o maior interessado, realmente, em procurar o máximo de conhecimento e metodologia científica para defender o seu produto. Essa é a realidade. Então é a própria evolução do conhecimento científico protegendo o homem.

Silva apud COMISSÃO TÉCNICA NACIONAL DE BIOSSEGURANÇA (2007)

\subsection{Considerações sobre os aspectos que nortearam a deliberação da CTNBio sobre o algodão RR da Monsanto.}

O algodão RR da Monsanto foi aprovado em 18 de setembro de 2008, com 16 votos favoráveis, 2 contrários e 3 abstenções.

Com relação aos aspectos abordados nas tabelas 3 e 4, será realizada uma análise comparativa entre as justificativas apresentadas no parecer final da CTNBio e dos pareceristas 
da Comissão, aliados às argumentações apresentadas na audiência pública. As considerações são as seguintes.

Quanto à Equivalência substancial, a CTNBio considerou a variedade equivalente substancialmente ao algodão convencional, baseando-se nas análises fenotípicas e de desempenho agronômico apresentados pela Monsanto. A única diferença seria a expressão do gene que confere resistência ao herbicida glifosato, mas, segundo a Comissão, este não é um fator suficiente para diferenciar o algodão transgênico do convencional. No entanto, não demonstra certeza científica neste aspecto, que pode ser observada na afirmação de que "as análises composicionais (proteínas, lipídios, fibras, carboidratos, aminoácidos, minerais, teor calórico, $\alpha$-tocoferol e gossipol) não mostraram “[...] diferenças significativas” (COMISSÃO TÉCNICA NACIONAL DE BIOSSEGURANÇA, 2008b) entre o evento MON1445 e o parental não-GM ou outras variedades comerciais".

Os relatórios apresentados pelos pareceristas da CTNBio apresentaram divergências neste aspecto em uma mesma subcomissão setorial. Enquanto alguns membros da Área Vegetal e Ambiental e da Área de Saúde Humana e Animal argumentaram em favor da equivalência substancial, baseando-se nos mesmos critérios apresentados no parecer final da CTNBio (características fenotípicas e agronômicas, com exceção da resistência ao glifosato), Paulo Kageyama, da área Ambiental e Victor Augustus, da área de Saúde, levantaram dúvidas a este respeito. Na Área Ambiental, Kageyama falou a respeito das diferenças entre as técnicas de melhoramento convencional e transgenia e de como a inserção de genes não nativos poderiam ocasionar efeitos imprevisíveis, ou seja, incertos. O parecerista também questionou o patenteamento da PGM se a mesma não difere da convencional. Já Victor Augustus também argumentou sobre a incerteza da equivalência, em razão da falta de mais estudos a serem realizados pela empresa, os quais se basearam nas proteínas isoladas expressas pelos transgenes e não no alimento inteiro. Efeitos sobre a fisiologia e morfologia de animais que se alimentam do farelo de algodão GM e do próprio óleo do algodão utilizado por humanos deveriam ser realizados. Com relação às argumentações da audiência pública, os integrantes favoráveis à liberação consideraram a PGM equivalente, enquanto os demais a tem como incerta.

Com relação à estabilidade genética, a CTNBio concluiu que o conjunto transgênico foi introduzido parcialmente em um único lócus do algodão, afirmando sua estabilidade em razão da integridade do DNA da PGM testada em diversas condições ambientais, em várias gerações de plantas. Alguns pareceristas da Área Vegetal/Ambiental e de Saúde Humana/Animal também concluíram o mesmo, com os primeiros desconsiderando as 
características ambientais locais como agentes que influenciam na estabilidade, enquanto os segundos argumentaram que a mesma se deu na análise de três gerações de plantas. Augustus levantou a dificuldade de se obter conclusões neste aspecto devido à má qualidade das fotos da inserção do transgene apresentada pela Monsanto e também pelo surgimento de um seqüenciamento de 500 pares de bases não pertencentes aos transgenes que foi apresentado pela empresa, concluindo pela incerteza da referida estabilidade. Na audiência pública, os defensores da liberação da PGM, representados, neste item, pelo palestrante da Monsanto, argumentaram de forma favorável à estabilidade, dada nas três gerações de plantas analisadas, o que foi considerado um número diminuto para os precaucionistas.

Outro aspecto considerado foi o potencial de toxicidade e alergenicidade da PGM aos animais, incluindo o ser humamo. A CTNBio, em seu parecer final, concluiu a respeito da inocuidade, pelos seguintes motivos: os organismos doadores e vetores dos transgenes não são patogênicos ao ser humano; a rápida degradabilidade das proteínas isoladas (codificadas pelo transgene) no sistema digestório, a partir de estudos realizados com camundongos e outros animais; não detectaram-se diferenças estatísticas no peso corporal e consumo de alimentos entre os grupos controle e submetidos à dieta com proteína isolada (por meio de injeções) e as proteínas transgênicas codificadas não possuem homologia com substâncias alergênicas conhecidas. Alguns dos pareceristas da Área Vegetal e Ambiental e de Saúde Humana e Animal também concluíram o mesmo, acrescentando que o glifosato apresenta baixa toxicidade a humanos e demais animais. Kageyama levantou a necessidade de verificar se as proteínas codificadas contém características de moléculas alergênicas ou compartilham sequências de aminoácidos com reação cruzada a outros alérgenos conhecidos, enquanto que Augustus apontou pela incerteza dos resultados, já que foram realizados em um curto espaço de tempo, além de não terem sido analisados a fisiologia, morfologia e peso dos órgãos dos animais estudados. As opiniões na audiência pública também foram contraditórias, com argumentos que defenderam a inocuidade da PGM e outros que abarcaram sua controvérsia, demonstrada pelo consumo do tomate Flavor GM nos EUA, retirado de circulação em função das alergias acometidas e que não foram previstas na análise de risco prévia.

Quanto ao potencial de fluxo gênico, a CTNBio não mencionou a possibilidade de ocorrência de fluxo gênico, mas sim as consequências de possíveis introgressões genéticas. Estas poderiam se dar apenas em espécies silvestres de algodão caso conferissem características adaptativas para sua permanência, as quais seriam, no presente caso, a utilização do herbicida. Portanto, a Comissão concluiu que fora da área agrícola e em locais onde não haja uso do glifosato, a vantagem seletiva proporcionada pelo transgene não 
ocorreria. Considerou que, durante o transporte da PGM, algumas sementes poderiam se estabelecer nas estradas e portos, mas os riscos ambientais seriam mínimos se se encontrarem fora de áreas agrícolas. Para evitar a possível contaminação das espécies silvestres, estabeleceu o não-plantio do algodão transgênico nas áreas de exclusão determinadas pelo MAPA.

Alguns pareceristas da Área Vegetal e Ambiental concluíram pela possibilidade de fluxo gênico via polinização ou dispersão de sementes, sendo a primeira dada em função da compatibilidade entre as espécies de algodão existentes no Brasil. No entanto, alegaram que, se tomadas medidas para o isolamento do algodão GM, as chances para o fluxo gênico seriam mínimas. Apontaram estudos que demonstraram a dispersão do pólen em distâncias máximas de $16 \mathrm{~m}$. Também concluíram que o estabelecimento do transgene nas espécies de algodão não GMs apenas se daria caso houvesse pressão de seleção nestas áreas, ou seja, o uso do herbicida ao qual o transgene é resistente. Quanto à dispersão de sementes e caroços de algodão durante o transporte, afirmaram a possibilidade de sua ocorrência, mas com difícil permanência, dada a inexistência de espécies de algodão invasoras no Brasil. Já Kageyama levantou a questão das abelhas polinizadoras do algodão, que alcançam elevadas distâncias de vôo, além de outros insetos que potencialmente polinizam o algodão. Alegou a existência de algodão não GM já contaminado no país, o que seria uma indicação da existência de fluxo gênico, e de estudos realizados pela EMBRAPA demonstrando a compatibilidade sexual entre a variedade GM com as espécies domesticadas e silvestres do Brasil gerando descendentes férteis. Os estudos realizados pela Monsanto no Brasil não foram demonstrativos para os diversos ecossistemas brasileiros, que possuem características ecológicas próprias, sendo uma questão importante para a avaliação de biossegurança do transgênico. Inclusive, a distância de 800 metros proposta pela CTNBio não previne o fluxo gênico por não levar em conta as diferenças entre os ecossistemas.

Na Área de Saúde apenas os pareceristas que até então se demonstraram favoráveis à liberação da PGM se manifestaram com os mesmos argumentos apresentados no parecer final da CTNBio, quais sejam, a dispersão do pólen em distâncias máximas entre 15 e 16 m, além da não existência de espécies invasoras que possam cruzar-se com o algodão. Também alegaram que o algodão GM não apresentou dormência de sementes, persistência no solo, germinação em condições adversas e dispersão de sementes a longas distâncias, o que diminuiria o fluxo gênico e a persistência do transgene.

$\mathrm{Na}$ audiência pública, os defensores da tecnologia apontaram para o baixo risco de fluxo gênico e introgressão nas espécies receptoras, enquanto que outros abordaram uma série 
de questões, como a desconsideração das áreas de plantio de algodão agroecológico nas zonas de exclusão definidas pelo MAPA, o que seria uma ameaça à perda da certificação destes produtos, além da necessidade de inserção do semi-árido nordestino na zona de exclusão, dada a existência de algodões nativos em todo o nordeste. O parecer final da CTNBio concluiu pelo risco mínimo de fluxo e introgressão gênica.

Quanto à capacidade de transferência vertical e horizontal, o parecer final da CTNBio argumentou sobre a possibilidade de transferência horizontal de genes, principalmente entre microorganismos em taxas baixas, mas a raridade da transferência vertical devido às distâncias evolutivas. Mesmo que houvesse a transferência do gene que confere resistência ao glifosato a outros microorganismos presentes no solo, não haveria riscos ambientais, já que estes degradam naturalmente o herbicida. O mesmo ocorreria caso os microorganismos recebessem o gene de resistência a antibióticos, pois estes não são utilizados em plantios comerciais. No entanto, afirmou-se que o gene promotor CaMV poderia ocasionar efeitos danosos na flora microbiana, "[...] mas que nada disso parece acontecer" (COMISSÃO TÉCNICA NACIONAL DE BIOSSEGURANÇA, 2008b). A maioria dos pareceristas da área Vegetal/Ambiental afirmaram o mesmo, dizendo que os riscos ambientais e à saúde seriam muito baixos e, na área de Saúde, afirmou-se a existência normal de genes de resistência a antibióticos no solo. Já Kageyama reclamou a ausência de estudos realizados pela empresa que confirmassem a improbabilidade de transferência horizontal. Afirmou também o conhecimento científico de transferência vertical entre bactérias e plantas a qual, envolvendo transgenes, poderia ocasionar impactos negativos sobre os ecossistemas. Os participantes da audiência pública apresentaram opiniões divergentes, sendo que alguns levantaram a possibilidade de transferência de genes marcadores de resistência no consumo de alimentos GM para bactérias intestinais. O parecer final da CTNBio concluiu para a impossibilidade de ocorrência de riscos neste sentido.

Em relação aos impactos sobre organismos alvo e não alvo, a CTNBio descartou danos potenciais aos mamíferos e aves, os primeiros por não se alimentarem de algodão (partes da planta, caroço, sementes). Sementes também não são utilizadas na produção de peixes e seu carreamento para águas superficiais é remoto em função de práticas agrícolas que visam a proteção das águas aos agrotóxicos e a grande necessidade de irrigação das culturas de algodão. Já no caso de invertebrados, sua exposição direta ou indireta (por predação) é provável para alguns grupos, principalmente daqueles que se alimentam de folhas e outros tecidos. Organismos polinizadores são expostos a pequenas quantidades de material recombinante, já que os transgenes são pouco expressos no pólen da PGM. Não há trabalhos 
publicados sobre os impactos resultantes do consumo de proteínas que conferem resistência ao glifosato sobre invertebrados, mas a empresa apresentou testes realizados no Brasil e EUAs que demonstraram sua inocuidade, já que a proteína EPSPS encontra-se em plantas, algas, fungos e bactérias. A proteína transgênica CP4-EPSPS não difere da EPSPS, de origem natural e, portanto, não oferece riscos para animais. Alguns pareceristas da Área Vegetal e Ambiental e da Área de Saúde apresentaram os mesmos argumentos. Apenas Kageyama diferiu em suas opiniões, pois parte de premissas metodológicas diferentes. Ao invés de analisar os efeitos que resultam do consumo da planta, abordou a necessidade de estudos sobre a exposição do herbicida glifosato, que será inevitavelmente utilizado na cultura do algodão transgênico, sobre os animais. Os efeitos cumulativos das aplicações sucessivas nos plantios deveriam ser, deste modo, avaliados, inclusive sobre a microbiota do solo. Os estudos sobre os efeitos do herbicida glifosato, de amplo espectro de uso, não foram realizados no Brasil. Além disto, há potenciais impactos secundários sobre pássaros e outros seres que se alimentam de plantas invasoras, organismos alvo da tecnologia.

$\mathrm{Na}$ audiência pública, os argumentos favoráveis se deram em relação ao controle das plantas invasoras do algodoeiro, enquanto que os participantes preocupados com o plantio comercial da PGM apresentaram as mesmas questões abordadas pelo parecerista da área ambiental, com relação aos impactos ocasionados pelo uso em larga escala do herbicida.

Quanto aos efeitos da PGM sobre o solo e as águas, a CTNBio a considerou inócua e biossegura, sem oferecer riscos ao ambiente. Alguns pareceristas da Área Vegetal e Ambiental e da Área de Saúde também consideraram os riscos muito baixos, já que o glifosato se degrada facilmente e se adere firmemente no solo, oferecendo impactos menores do que as variedades convencionais. Já Kageyama apontou para impactos ambientais incertos, pelo fato de a empresa não apresentar os estudos que demonstram a elevada biodegradabilidade do herbicida e seus resíduos no solo e plantas. Também apontou estudos que indicaram que a permanência do herbicida depende do tipo de solo. Na audiência pública, os participantes favoráveis à liberação argumentaram sobre a redução do uso de herbicidas com o uso da PGM e as consequentes vantagens ambientais que este fato proporciona. No entanto, outros participantes levantaram os danos em longo prazo, dados em função da resistência das plantas invasoras ao glifosato e o aumento de sua utilização.

No caso de PGMs resistentes a herbicidas, uma das questões mais polêmicas foram os efeitos ao longo prazo do uso do agroquímico sobre as plantas invasoras e sua possível resistência em função da pressão seletiva. Neste aspecto, praticamente todos os agentes sociais que participaram nas discussões concordaram que em algum momento a resistência 
surgirá, sendo que os defensores da tecnologia apostam geralmente em medidas preventivas ou corretivas para saná-la. No parecer final da CTNBio recomendou-se o emprego de boas práticas agrícolas, como a rotação de culturas e de herbicidas para a mitigação do problema. Alguns relatores das Áreas Ambiental/Vegetal também apontaram soluções neste sentido, enquanto Kageyama apresentou estudos que demonstraram a aceleração no surgimento de plantas invasoras após a liberação comercial de PGMs. Na audiência pública, este fato também foi apontado como inevitável por praticamente todos os participantes, mas as opiniões se dividiram quanto à solução do problema, por medidas mitigadoras ou pela adoção do princípio da precaução, com a não liberação do OGM. Alguns participantes levantaram a existência de diversas plantas invasoras na Argentina e mesmo no Brasil, após a introdução da soja RR, que conduziu o Ministério da Saúde a aprovar o aumento da dose do glifosato em 50 vezes para o adiamento da resistência.

Quanto à coexistência entre as variedades de algodão transgênico, convencional e orgânico, a CTNBio afirmou inexistir no Brasil o cultivo de variedades de algodão crioulas com coexistência, sem contaminações, entre os diversos sistemas de produção. Relatores da Área Vegetal/Ambiental também afirmaram a possibilidade da coexistência, desde que sejam respeitadas as zonas de exclusão ao algodão transgênico, enquanto que Kageyama apontou para diversos relatos de contaminação já existentes no Brasil. Na audiência pública, as opiniões também foram bastante controversas, pois os defensores da liberação argumentaram a favor do direito de escolha do agricultor em adotar o sistema produtivo que desejar, podendo modificá-lo caso haja consequências desfavoráveis, proclamando uma coexistência possível. Já outros participantes opinaram sobre sua impossibilidade, destacando a ocorrência de contaminações por transgenes em 39 países, sendo que, em alguns casos, chegou-se a 15 ou $20 \%$ de toda a produção de convencionais ou orgânicos.

Em relação às vantagens econômicas da liberação do algodão RR, a CTNBio argumentou pelo aumento da produtividade dada com a redução do uso de herbicidas pela variedade. Os pareceristas da Área Ambiental e Vegetal valorizaram estes mesmos aspectos, acrescentando a inexistência de cultivos GM improdutivos no Brasil e seu maior desenvolvimento quando utilizadas as doses indicadas do glifosato na época recomendada. Os relatores da área de saúde também apontaram o aumento da produtividade, mas com o cuidado de não se utilizar uma dosagem maior do herbicida, que poderia ocasionar riscos de toxicidade. Kageyama apresentou uma série de desvantagens com a liberação da PGM em questão, tais como um possível aumento dos custos das sementes, fato sucedido com a soja RR, também da Monsanto, cujo aumento se deu na ordem de 16,67\% na safra 2008/2009, 
além da não comprovação de aumento nos rendimentos por parte dos agricultores que adotaram cultivos GMs. A estes fatos se soma um possível aumento na aplicação de herbicidas, caso ocorram resistências. Os participantes da audiência pública apresentaram argumentos favoráveis e desfavoráveis neste aspecto. Como favoráveis, além dos já citados, há a diminuição da necessidade de mão-de-obra no campo, dada a facilidade no manejo da cultura; o aumento nas exportações de produtos agrícolas e da competitividade nos mercados externos; a possibilidade de investimento em biotecnologia na EMBRAPA (reduzindo os custos com a compra das sementes), dentre outros. Já outros participantes externaram suas preocupações com a dependência do agricultor pelo pacote tecnológico vendido pela empresa, a perda de sementes crioulas e da milenar tradição de troca de sementes entre os agricultores, além de argumentarem sobre a existência dos transgênicos como estratégia mercadológica das empresas produtoras, que estariam interessadas em vender mais agroquímicos.

No item recomendações e restrições, o parecer final da CTNBio condicionou a aprovação da PGM ao cumprimento da Lei 11.460, de 21 de março de 2007, em que "ficam vedados a pesquisa e o cultivo de organismos geneticamente modificados nas terras indígenas e áreas de unidades de conservação" e da Normativa $n^{\circ} 5$, de 12 de março de 2008, por meio da qual a requerente tem o prazo de 30 dias a partir da publicação do Parecer final para adequar sua proposta de plano de monitoramento pós-liberação comercial, o que indica a não necessidade deste requisito para a avaliação. Os pareceristas da área Vegetal/Ambiental recomendaram o respeito às zonas de exclusão ao algodão $\mathrm{GM}$, a rotação de culturas e herbicidas para evitar a resistência, além da destruição dos resíduos da PGM, que dependem exclusivamente do bom senso do agricultor. Enquanto isto, Kageyama apontou uma lista de recomendações que podem ser assim resumidas: a apresentação dos dados brutos resultantes dos estudos realizados pela empresa quanto aos resíduos do glifosato nas diversas partes da planta, no solo e seus efeitos prováveis; a avaliação de impacto ambiental do uso do herbicida em espécies indicadoras; o monitoramento pós-comercial da PGM; exigência, por parte da CTNBio, de estudos sobre transferência horizontal e vertical, não feitos pela empresa; a realização de EIA para que a empresa demonstre a inexistência de potenciais impactos ambientais com a liberação da PGM; a realização de estudos sobre os metabólitos do glifosato nos diversos ecossistemas brasileiros, pois um deles, o AMPA é comprovadamente danoso à fauna terrestre; estudos sobre a velocidade do surgimento de plantas invasoras resistentes; o isolamento do algodão PGM em função das especificidades locais e a realização de estudos em todos os ecossistemas brasileiros baseando-se em aspectos ecológicos e não agronômicos, como feito. 
Na audiência pública, questionou-se a ausência de monitoramento e fiscalização pelos órgãos responsáveis; a impossibilidade destes participarem nas tomadas de decisões a respeito da liberação de PGMs e a falta de articulação institucional; do descumprimento do princípio da precaução por parte da CTNBio e sua composição, formada principalmente por biotecnólogos; os interesses econômicos predominantes das bioindústrias, dos grandes produtores rurais e dos pesquisadores da área de biotecnologia sobre as decisões finais da Comissão; o desrespeito dos produtores de algodão GM às zonas de exclusão, fato constatado pelos atos de infração dados pelo MAPA, dentre outros

No parecer final da CTNBio, foram apresentados os votos divergentes à liberação da PGM e as justificativas dos pareceristas para tanto, conforme disposto na Lei de Biossegurança de 2005.

Em relação à bibliografia apresentada no parecer final da Comissão, foram praticamente desconsideradas aquelas indicadas pelos pareceristas que argumentaram contrariamente à liberação da PGM (nenhuma de Victor Augustus e apenas quatro das trinta e quatro referências apresentadas por Kageyama). Com relação aos relatores que argumentaram favoravelmente, um número maior de referências foi relatada.

\section{$\checkmark$ Comentários}

Existem conflitos em todo o processo de discussão da variedade transgênica em análise, como observado nos pareceres das subcomissões setoriais e na audiência pública. Nas considerações da CTNBio, apenas os comentários abordados pelos relatores que se demonstraram favoráveis à liberação obtiveram relevância, em detrimento dos questionamentos realizados pelos dois pareceristas que foram contrários, mesmo que respaldados por estudos científicos apresentados em suas referências bibliográficas. Os argumentos levantados por estes refletem a discordância existente na comunidade científica internacional acerca dos princípios e metodologias utilizadas nas análises de risco de OGMs, tais como o Princípio da Equivalência Substancial, a estabilidade genética, a transferência horizontal dos transgenes, sua biodegrabilidade no solo, dentre outros.

Como explicitado no Protocolo de Cartagena, a análise de risco necessita considerar as características do ambiente receptor do OGM, mas a empresa solicitante não apresentou tais estudos. Ao invés disto, os testes de campo foram efetuados em poucas localidades, por um curto intervalo temporal e levou em conta, sobretudo, os aspectos relacionados com o 
desempenho agronômico da variedade GM. Além disto, as preocupações da sociedade observadas na audiência pública, que também refletem as controvérsias científicas sobre os princípios e métodos de análise de risco de OGMs foram em parte desconsideradas e, não obstante o pressuposto presente na Lei de Biossegurança de avaliação dos OGMs caso-a-caso, diversas variedades GMs foram abordadas conjuntamente na audiência.

\subsection{Questionário para sistematizar as opiniões de setores da sociedade}

Para realizar uma coleta de opiniões de diversos setores da sociedade no tocante a alguns aspectos do sistema regulatório de OGMs no Brasil, tais como transparência dos mecanismos decisórios, participação da sociedade, coordenação entre as instituições atuantes, acesso às informações, instrumentos utilizados para os estudos ambientais das PGMs, dentre outros, foi elaborado e aplicado um questionário junto a estes setores. As questões foram enviadas a 140 potenciais respondentes especializados nas áreas de biotecnologia, biossegurança, meio ambiente, ecologia, direito e regulamentação, além de organizações nãogovernamentais que participam do debate nacional sobre OGMs. O critério para a seleção dos potenciais participantes baseou-se na atuação em áreas que fazem interface direta ou indireta com o assunto em questão.

No final do período disposto para o retorno do questionário obteve-se 37 respostas que corresponderam a $26 \%$ do total enviado.

As análises foram realizadas para a totalidade dos participantes, visando uma prospecção geral das opiniões obtidas. Para tanto, os dados obtidos foram processados utilizando-se ferramentas estatísticas e apresentados por meio de tabelas contendo as porcentagens e frequências para as alternativas presentes em cada questão, seguidas por comentários. A fim de identificar potenciais divergências de visões segundo a especialidade dos participantes, efetuou-se uma análise comparativa entre cada grupo de especialistas, que foram classificados em categorias, do seguinte modo.

Categoria 01: especialistas em Biotecnologia e/ou Biossegurança;

Categoria 02: especialistas em Direito e Regulamentação;

Categoria 03: especialistas em Ecologia;

Categoria 04: especialistas em Meio Ambiente;

Categoria 05: atuantes em ONGs.

Aos participantes foi possibilitada a determinação de sua área de atuação e, na categoria 01, biotecnólogos e especialistas em biossegurança foram agrupados conjuntamente, 
apesar de se constituírem em áreas distintas, devido à auto identificação de seus membros como atuantes em ambas as áreas com uma única exceção, em que o participante classificouse como especialista em biossegurança, exclusivamente.

A Tabela 4 mostra o percentual de respostas por categoria em função da quantidade de questionários enviados:

Tabela 04 - Percentual de respostas em função dos questionários enviados por categorias.

\begin{tabular}{cccc}
\hline Categorias & $\begin{array}{c}\text { Questionários } \\
\text { enviados }\end{array}$ & $\begin{array}{c}\text { Questionários } \\
\text { respondidos }\end{array}$ & Porcentagem de respostas \\
\hline 01 & 47 & 6 & $13 \%$ \\
\hline 02 & 18 & 4 & $22 \%$ \\
\hline 03 & 18 & 7 & $39 \%$ \\
\hline 04 & 35 & 12 & $34 \%$ \\
\hline 05 & 22 & 8 & $36 \%$ \\
\hline TOTAL & $\mathbf{1 4 0}$ & $\mathbf{3 7}$ & $\mathbf{2 6 \%}$ \\
\hline
\end{tabular}

Conforme a tabela 4 observa-se que as categorias que apresentam maior porcentagem de respostas em relação à quantidade de questionário enviados foram, respectivamente: "Ecologia", "ONGs", Meio Ambiente", "Direito e Regulamentação" e "Biotecnologia e/ou Biossegurança".

A tabela 5 apresenta, por sua vez, as frequências e porcentagens dos respondentes por cada categoria de atuação:

Tabela 5 - Frequências e porcentagens dos respondentes por categorias de atuação.

\begin{tabular}{ccc}
\hline CATEGORIAS & FREQUÊNCIA & PORCENTAGEM \\
\hline 01 & 6 & $16 \%$ \\
\hline 02 & 4 & $11 \%$ \\
\hline 03 & 7 & $19 \%$ \\
\hline 04 & 12 & $32 \%$ \\
\hline 05 & 8 & $22 \%$ \\
\hline TOTAL & 37 & $100 \%$ \\
\hline
\end{tabular}

De acordo com a tabela 5, nota-se que o maior número de respostas obtidas foram, em oderm decrescente, as seguintes categorias: "Meio Ambiente", "ONGs", "Ecologia", "Biotecnologia e/ou Biossegurança" e "Direito e Regulamentação".

A seguir serão apresentadas e comentadas as questões respondidas.

Questão 01: Em relação à liberação do plantio em escala comercial de PGMs, qual das alternativas expressa melhor sua opinião: 
1. Devem ser considerados os interesses e objetivos das Políticas do setor agrícola, do setor econômico, as questões fundiárias, a política ambiental da região, Estado ou País.

2. Não devem ou não precisam ser considerados os interesses e objetivos das Políticas do setor agrícola, do setor econômico, as questões fundiárias, a política ambiental da região, Estado ou País

3. Outra opinião.

Tabela 6 - Consideração de outras Políticas, Planos e Programas para a liberação de PGMs.

\begin{tabular}{ccc}
\hline OPÇÕES & FREQUÊNNCIA & PORCENTAGEM \\
\hline Sim & 27 & $73,0 \%$ \\
\hline Não & 1 & $2,7 \%$ \\
\hline Outra & 9 & $24,3 \%$ \\
\hline TOTAL & 37 & $100 \%$ \\
\hline
\end{tabular}

Gráfico 1 -. Consideração de outras Políticas, Planos e Programas para a liberação de PGMs.

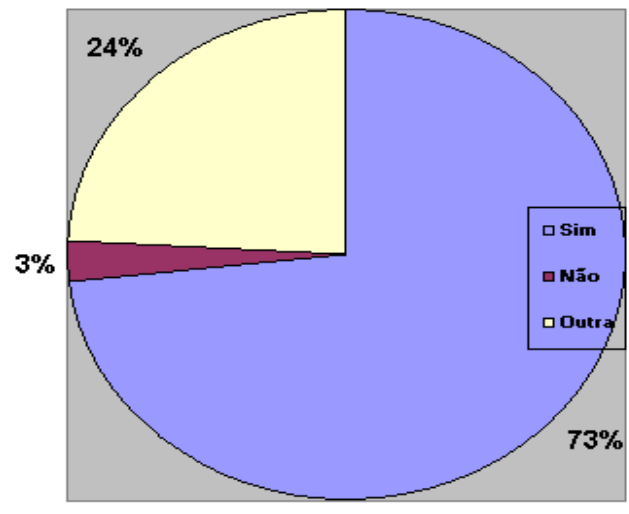

Tabela 7 - Consideração de outras Políticas, Planos e Programas para a liberação de PGMs segundo cada categoria.

\begin{tabular}{ccccc}
\hline Categorias & Alternativa 01 & Alternativa 02 & Alternativa 03 & Total \\
\hline 01 & 2 & 1 & 3 & 6 \\
\hline 02 & 4 & 0 & 0 & 4 \\
\hline 03 & 6 & 0 & 1 & 7 \\
\hline 04 & 10 & 2 & 0 & 12 \\
\hline 05 & 5 & 0 & 3 & 8 \\
\hline
\end{tabular}

A tabela 6 e seu correspondente gráfico evidenciam que a maioria dos respondentes considera importante ter em conta os objetivos de Políticas, Planos e Programas relacionados com a liberação de PGMs em seu processo avaliatório. Com relação às respostas obtidas por categorias, cabe destacar que todas as áreas, com exceção da categoria 01 (biotecnologia e/ou 
biossegurança) tiveram a maioria dos seus membros considerando importantes as PPPs relacionadas. Obteve-se metade de respostas para a opção "outra" entre os biotecnólogos e especialistas em biossegurança.

As categorias 02, 03 e 04 apresentaram as maiores frequências de respostas a favor da consideração das Políticas, Planos e Programas que se relacionem ao assunto.

Questão 02: Indique quais os seguintes segmentos da sociedade devem participar do processo decisório envolvendo a liberação ambiental de PGMs, além das autoridades competentes.

Tabela 8 - Agentes sociais que devem participar das decisões sobre a liberação de PGMs (para a totalidade dos respondentes).

\begin{tabular}{ccc}
\hline Participantes & Sim & Não \\
\hline Biotecnólogos & $78,4 \%$ & $21,6 \%$ \\
\hline Biossegurança & $100 \%$ & $0 \%$ \\
\hline Ecologia & $89,2 \%$ & $10,8 \%$ \\
\hline Meio Ambiente & $94,6 \%$ & $5,4 \%$ \\
\hline Saúde & $91,9 \%$ & $8,1 \%$ \\
\hline Produtores agrícolas & $70,3 \%$ & $29,7 \%$ \\
\hline Consumidores & $81,1 \%$ & $18,9 \%$ \\
\hline Ambientalistas & $64,9 \%$ & $35,1 \%$ \\
\hline Outros & $24,3 \%$ & $75,7 \%$ \\
\hline
\end{tabular}

Gráfico 2 - Agentes sociais que devem participar das decisões sobre a liberação de PGMs (para a totalidade dos respondentes).

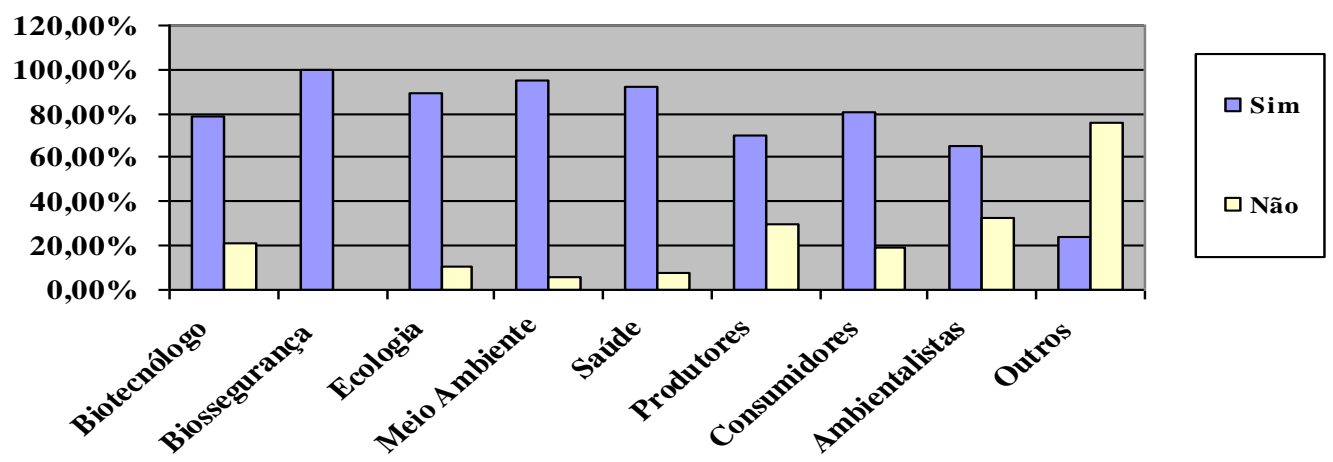


Tabela 9 - Agentes sociais que devem participar das decisões sobre a liberação de PGMs, segundo a categoria 01 (Biotecnologia e Biossegurança).

\begin{tabular}{cccc}
\hline Participantes & Sim (Frequência) & Não (Frequência) & Total \\
\hline Biotecnólogos & 4 & 2 & 6 \\
\hline Biossegurança & 6 & 0 & 6 \\
\hline Ecologia & 4 & 2 & 6 \\
\hline Meio Ambiente & 4 & 2 & 6 \\
\hline Saúde & 3 & 3 & 6 \\
\hline Produtores agrícolas & 2 & 4 & 6 \\
\hline Consumidores & 1 & 5 & 6 \\
\hline Ambientalistas & 1 & 5 & 6 \\
\hline
\end{tabular}

Tabela 10 - Agentes sociais que devem participar das decisões sobre a liberação de PGMs, segundo a categoria 02 (Direito e Regulamentação).

\begin{tabular}{cccc}
\hline Participantes & Sim (Frequência) & Não (Frequência) & Total \\
\hline Biotecnólogos & 3 & 1 & 4 \\
\hline Biossegurança & 4 & 0 & 4 \\
\hline Ecologia & 3 & 1 & 4 \\
\hline Meio Ambiente & 4 & 0 & 4 \\
\hline Saúde & 4 & 0 & 4 \\
\hline Produtores agrícolas & 3 & 1 & 4 \\
\hline Consumidores & 4 & 0 & 4 \\
\hline Ambientalistas & 3 & 1 & 4 \\
\hline
\end{tabular}

Tabela 11 - Agentes sociais que devem participar das decisões sobre a liberação de PGMs, segundo a categoria 03 (Ecologia).

\begin{tabular}{cccc}
\hline Participantes & Sim (Frequência) & Não (Frequência) & Total \\
\hline Biotecnólogos & 6 & 1 & 7 \\
\hline Biossegurança & 7 & 0 & 7 \\
\hline Ecologia & 7 & 0 & 7 \\
\hline Meio Ambiente & 7 & 0 & 7 \\
\hline Saúde & 7 & 0 & 7 \\
\hline Produtores agrícolas & 5 & 2 & 7 \\
\hline Consumidores & 6 & 1 & 7 \\
\hline Ambientalistas & 6 & 1 & 7 \\
\hline Outro(s) & 2 & 5 &
\end{tabular}

Tabela 12 - Agentes sociais que devem participar das decisões sobre a liberação de PGMs, segundo a categoria 04 (Meio Ambiente).

\begin{tabular}{cccc}
\hline Participantes & Sim (Frequência) & Não (Frequência) & Total \\
\hline Biotecnólogos & 11 & 1 & 12 \\
\hline Biossegurança & 12 & 0 & 12 \\
\hline Ecologia & 12 & 0 & 12 \\
\hline Meio Ambiente & 12 & 0 & 12 \\
\hline Saúde & 12 & 0 & 12 \\
\hline Produtores agrícolas & 11 & 1 & 12 \\
\hline Consumidores & 11 & 1 & 12 \\
\hline Ambientalistas & 8 & 4 & 12 \\
\hline Outro(s) & 3 & 9 & 12
\end{tabular}


Tabela 13 - Agentes sociais que devem participar das decisões sobre a liberação de PGMs, segundo a categoria 05 (ONGs).

\begin{tabular}{cccc}
\hline Participantes & Sim (Frequência) & Não (Frequência) & Total \\
\hline Biotecnólogos & 5 & 3 & 8 \\
\hline Biossegurança & 8 & 0 & 8 \\
\hline Ecologia & 7 & 1 & 8 \\
\hline Meio Ambiente & 8 & 0 & 8 \\
\hline Saúde & 8 & 0 & 8 \\
\hline Produtores agrícolas & 5 & 3 & 8 \\
\hline Consumidores & 8 & 0 & 8 \\
\hline Ambientalistas & 6 & 2 & 8 \\
\hline Outros & 5 & 3 & 8
\end{tabular}

A maioria dos respondentes pensa ser importante a participação de uma diversidade de agentes sociais nas tomadas de decisão, conforme apresentado na Tabela 8 e no Gráfico 2. De modo geral, todos os setores obtiveram uma representação aproximada nas respostas, com exceção de "produtores" e "ambientalistas", cujos valores apresentaram-se mais baixos. A participação de especialistas em biossegurança, por sua vez, é considerada importante de forma unânime.

Quanto às categorias em específico, destaca-se na primeira que 4 em 6 dos respondentes opinaram a favor da participação de biotecnólogos, apesar da atuação de 5 dos participantes nesta área. Além disto, 5 são desfavoráveis à participação de ambientalistas e consumidores e 4 em 6 discordam da atuação dos produtores. Tal categoria apresentou as maiores restrições à participação social no processo decisório sobre a liberação de PGMs em relação às demais. Cabe-se destacar dois comentários com conteúdo diverso feitos pelos participantes desta categoria, entre o atuante na área de biossegurança, que acha importante a participação de "pequenos e grandes [produtores] da agricultura familiar e orgânica" (RESPONDENTE 05) enquanto que o respondente 03 (biotecnólogo) opinou da seguinte forma:

\footnotetext{
"Todos devem participar discutindo o assunto, mas os aspectos técnicos devem prevalecer. Não podemos deixar questões ideológicas e opiniões baseadas no "achismo" predominarem. É necessário ter uma discussão e uma decisão utilizando dados científicos, econômicos, sociais e ambientais.
}

(RESPONDENTE 03)

Já a maioria dos respondentes da categoria 05 , cujos diversos membros pertencem às associações ambientalistas, considerou a participação dos biotecnólogos como importante. A categoria "Direito e Regulamentação" foi a mais favorável quanto a uma maior participação dos agentes sociais interessados no processo decisório, seguidos de "Meio Ambiente" e "Ecologia". 
Além dos agentes sociais indicados, alguns ecólogos sugeriram outros, tais como: membros relacionados à indústria de alimentos, da área de comunicação social e de mercado. Já os respondentes da área de Meio Ambiente sugeriram: especialistas em economia, sociologia rural e da área jurídica.

No tocante às ONGs, outros agentes sociais foram levantados, tais como: especialistas em antropologia, psicologia, sociologia; comunidades tradicionais (como quilombolas e índios), ONGs e laboratórios que testam OGMs. Dentre os comentários apresentados, podemse citar:

Ambientalistas responsáveis, de visão holística e conscientes dos efeitos positivos e negativos da tecnologia em comparação às técnicas atuais e os desafios mundiais, mas não aqueles que se dizem ambientalistas e na verdade são contra o uso de qualquer tecnologia nova, globalização, etc [...].

(RESPONDENTE 31)

Hoje no processo de liberação do plantio dos OGMs há uma participação direta dos produtores, no caso das empresas que produzem sementes, além. dos produtores que estão interessados no plantio. A participação deles deveria ser restrita somente na hora de receberem orientação como deveriam ser plantadas as sementes GMs.

(RESPONDENTE 32)

Questão 03: Em sua opinião, quais das seguintes instituições deveriam ter o poder decisório final a respeito da liberação comercial de PGMs?

Tabela 14 - Instituições que devem participar da tomada de decisões sobre a liberação de PGMs (para a totalidade dos respondentes).

\begin{tabular}{ccc}
\hline Participantes & Sim & Não \\
\hline CTNBio & $32,4 \%$ & $67,6 \%$ \\
\hline CNBS & $29,8 \%$ & $70,2 \%$ \\
\hline MMA & $21,6 \%$ & $78,4 \%$ \\
\hline MAPA & $10,8 \%$ & $89,2 \%$ \\
\hline MCT & $13,5 \%$ & $86,5 \%$ \\
\hline MS & $24,3 \%$ & $75,7 \%$ \\
\hline Todas as instituições & $24,3 \%$ & $75,7 \%$ \\
\hline Outra & $18,9 \%$ & $81,1 \%$ \\
\hline
\end{tabular}


Gráfico 3 - Instituições que devem participar da tomada de decisões sobre a liberação de PGMs (para a totalidade dos respondentes).

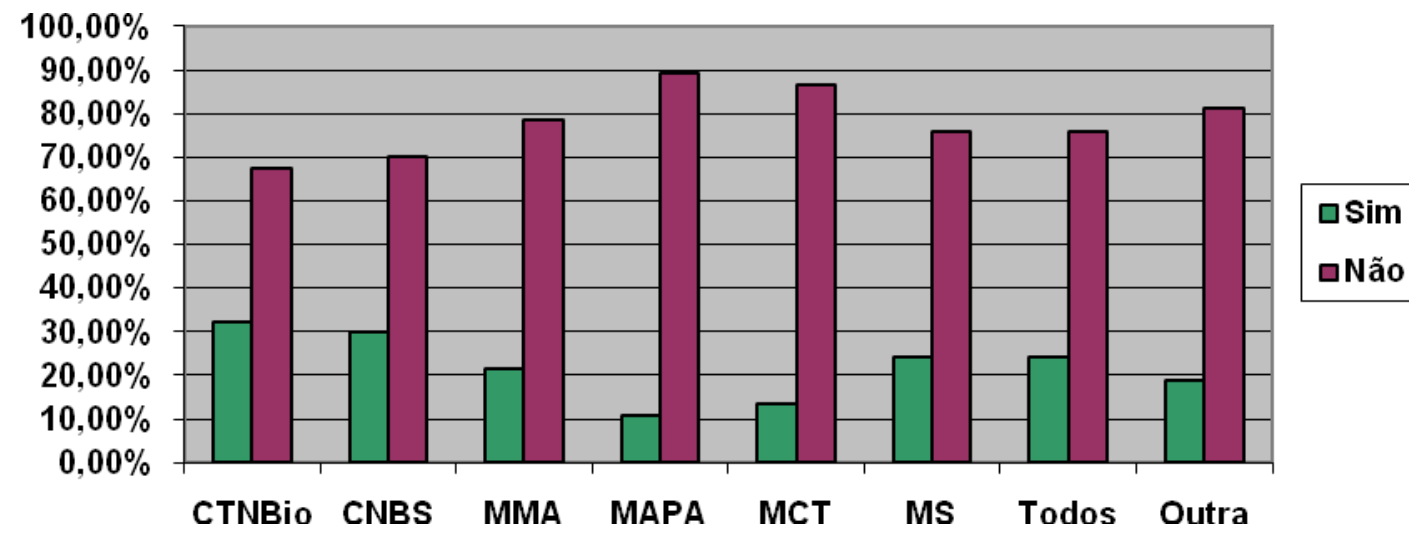

Tabela 15 - Instituições que devem participar da tomada de decisões sobre a liberação de PGMs, segundo a categoria 01 (Biotecnologia e/ou Biossegurança).

\begin{tabular}{cccc}
\hline Participantes (Frequência) & Sim (Frequência) & Não (Frequência) & Total \\
\hline CTNBio & 4 & 2 & 6 \\
\hline CNBS & 2 & 4 & 6 \\
\hline MMA & 1 & 5 & 6 \\
\hline MAPA & 1 & 5 & 6 \\
\hline MCT & 0 & 6 & 6 \\
\hline MS & 1 & 5 & 6 \\
\hline Todas as instituições & 0 & 6 & 6 \\
\hline Outra & 1 & 5 &
\end{tabular}

Tabela 16 - Instituições que devem participar da tomada de decisões sobre a liberação de PGMs, segundo a categoria 02 (Direito e Regulamentação).

\begin{tabular}{cccc}
\hline Participantes (Frequência) & Sim (Frequência) & Não (Frequência) & Total \\
\hline CTNBio & 1 & 3 & 4 \\
\hline CNBS & 1 & 3 & 4 \\
\hline MMA & 0 & 4 & 4 \\
\hline MAPA & 0 & 4 & 4 \\
\hline MCT & 0 & 4 & 4 \\
\hline MS & 0 & 4 & 4 \\
\hline Todas as instituições & 2 & 2 & 4 \\
\hline Outra & 1 & 3 &
\end{tabular}

Tabela 17 - Instituições que devem participar da tomada de decisões sobre a liberação de PGMs, segundo a categoria 03 (Ecologia).

\begin{tabular}{cccc}
\hline Participantes (Frequência) & Sim (Frequência) & Não (Frequência) & Total \\
\hline CTNBio & 1 & 6 & 7 \\
\hline CNBS & 2 & 4 & 7 \\
\hline MMA & 1 & 6 & 7 \\
\hline MAPA & 1 & 6 & 7 \\
\hline MCT & 0 & 7 & 7 \\
\hline MS & 1 & 6 & 7 \\
\hline Todas as instituições & 4 & 3 & 7 \\
\hline Outra & 1 & 6 &
\end{tabular}


Tabela 18 - Instituições que devem participar da tomada de decisões sobre a liberação de PGMs, segundo a categoria 04 (Meio Ambiente).

\begin{tabular}{cccc}
\hline Participantes (Frequência) & Sim (Frequência) & Não (Frequência) & Total \\
\hline CTNBio & 5 & 7 & 12 \\
\hline CNBS & 4 & 8 & 12 \\
\hline MMA & 3 & 9 & 12 \\
\hline MAPA & 1 & 11 & 12 \\
\hline MCT & 2 & 10 & 12 \\
\hline MS & 3 & 9 & 12 \\
\hline Todas as instituições & 2 & 10 & 12 \\
\hline Outra & 4 & 8 &
\end{tabular}

Tabela 19 - Instituições que devem participar da tomada de decisões sobre a liberação de PGMs, segundo a categoria 05 (ONGs).

\begin{tabular}{cccc}
\hline Participantes (Frequência) & Sim (Frequência) & Não (Frequência) & Total \\
\hline CTNBio & 1 & 7 & 8 \\
\hline CNBS & 2 & 6 & 8 \\
\hline MMA & 3 & 5 & 8 \\
\hline MAPA & 1 & 7 & 8 \\
\hline MCT & 3 & 5 & 8 \\
\hline MS & 4 & 4 & 8 \\
\hline Todas as instituições & 4 & 4 & 8 \\
\hline Outra & 3 & 5 &
\end{tabular}

Na Tabela 14 e Gráfico 03, os órgãos governamentais considerados mais aptos a tomar decisões finais a respeito da liberação de PGMs são a CTNBio e o CNBS, atualmente responsáveis pelas avaliação e autorização dos processos submetidos pelas empresas e demais instituições. No entanto, alguns respondentes discordaram do fato, demonstrando um possível descontentamento com a definição destes órgãos como instâncias decisórias superiores. Um fato a ser destacado nesta questão é a porcentagem relativamente baixa alcançada pelo MMA, órgão que abrange o IBAMA e demais instituições governamentais que, por lei, têm a incumbência de decidir sobre o licenciamento das atividades potencialmente poluidoras, dentre as quais se encontra a liberação ambiental de OGMs. Infere-se, deste modo, que há um certo desconhecimento dos participantes sobre o assunto.

Em relação às categorias, o grupo de "Biotecnologia e/ou Biossegurança" foi o mais refratário à atuação da grande maioria dos órgãos governamentais apontados, considerando apenas a CTNBio como instância decisória superior, demonstrando-se contrário à atuação do Ministério da Ciência e Tecnologia, do qual a CTNBio faz parte. Na categoria "Direito e Regulamentação", metade dos respondentes foi favorável a uma maior coordenação institucional, sendo que apenas um dos respondentes, atuante nesta área é favorável à 
participação exclusiva da CTNBio e CNBS. Um dos respondentes apresentou a seguinte proposta: "Agência específica criada para tal fim e que responda juridicamente pelas decisões tomadas". (RESPONDENTE 09).

Os ecólogos foram favoráveis, em sua maioria, a uma atuação conjunta de todos os órgãos apresentados. Alguns respondentes apresentaram também algumas sugestões na alternativa "Outra", cabendo-se citar:

A CTNBio deveria ter uma função consultiva e ser composta por especialistas e representantes de grupos de interesse com boa formação acadêmica nas áreas de ciências ambientais e de segurança de alimentos. A decisão final deveria ser feita pelo CNBS e partir do posicionamento dos ministérios acima citados baseado no parecer técnico consultivo da CTNBio.

(RESPONDENTE 11)

Além do Estado, as representações da sociedade civil devem ter participação nas decisões sobre a liberação de OGMs no ambiente, dentre elas a representação dos consumidores (IDEC), conselhos representativos dos médicos e ambientalistas principalmente.

(RESPONDENTE 12)

A maioria dos representantes da categoria "Meio Ambiente" optou pela CTNBio como instância superior na tomada de decisão final. Algumas proposições foram feitas, levantando-se em conta a necessidade de participação também da sociedade civil, dentre as quais podem-se citar: "Um fórum ampliado, representativo da sociedade, avaliando e decidindo partir de informações técnicas e políticas" (RESPONDENTE 21); "Todas e representantes da sociedade e da saúde" (RESPONDENTE 22); "Poderia ser a CTNBio, mas precisaria modificar a sua composição, para que a diversidade de setores e posições da sociedade estivessem ali representados" (RESPONDENTE 25); "CONAMA" (RESPONDENTE 29).

Já a maioria dos membros de ONGs optou pela participação de todos os órgãos governamentais citados, também com algumas proposições principalmente em torno da atuação da sociedade civil, quais sejam: "Acho que o estado deveria fazer um amplo debate com a sociedade sobre o que são? Qual o objetivo? E que benefícios trazem as Plantas GM" (RESPONDENTE 32); “Com participação da sociedade civil”" (RESPONDENTE 34); “Os consumidores de alimentos" (RESPONDENTE 35); “OAB-CNBB-EMATER-PrefeiturasABI-ANVISA-IDEC-PROCON" (RESPONDENTE 37). 
Questão 04: Em sua opinião, o instrumento Estudo de Impacto Ambiental/Relatório de Impacto Ambiental (EIA/RIMA) é adequado para a avaliação dos impactos ambientais para a liberação de plantio de PGMs em escala comercial, quanto aos seguintes aspectos:

Tabela 20 - Adequação do EIA/RIMA para a AIA de PGMs (para todos os respondentes).

\begin{tabular}{cccc}
\hline Critérios & Sim & Não & Não sabe \\
\hline Impactos cumulativos & $40,5 \%$ & $54,1 \%$ & $5,4 \%$ \\
\hline $\begin{array}{c}\text { Alternativas } \\
\text { tecnológicas }\end{array}$ & $40,5 \%$ & $54,1 \%$ & $5,4 \%$ \\
\hline $\begin{array}{c}\text { Alternativas } \\
\text { locacionais }\end{array}$ & $37,8 \%$ & $51,4 \%$ & $10,8 \%$ \\
\hline $\begin{array}{c}\text { Consideração de } \\
\text { PPPs }\end{array}$ & $45,9 \%$ & $48,7 \%$ & $5,4 \%$ \\
\hline Monitoramento & $37,8 \%$ & $56,8 \%$ & $5,4 \%$ \\
\hline Participação social & $35,1 \%$ & $59,5 \%$ & $5,4 \%$ \\
\hline
\end{tabular}

Gráfico 4 - Adequação do EIA/RIMA para a AIA de PGMs.

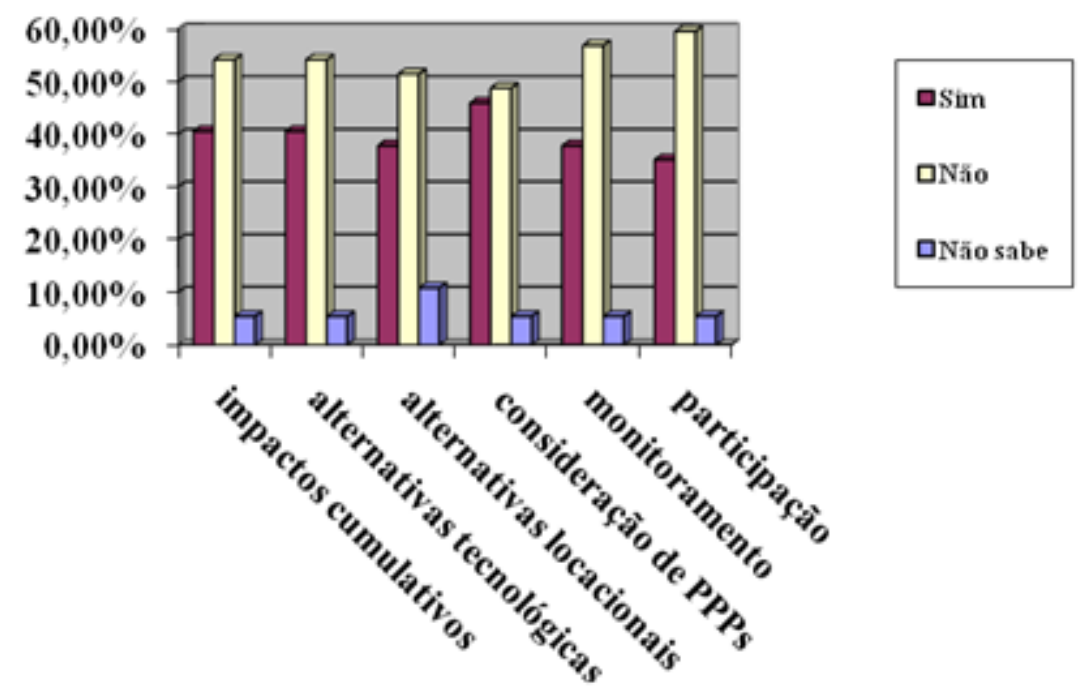

Tabela 21 - Adequação do EIA/RIMA para a AIA de PGMs, segundo a categoria 01 (Biotecnologia e/ou Biossegurança).

\begin{tabular}{cccc}
\hline Critérios & Sim (Frequência) & Não (Frequência) & Total \\
\hline Impactos cumulativos & 1 & 5 & 6 \\
\hline $\begin{array}{c}\text { Alternativas } \\
\text { tecnológicas }\end{array}$ & 1 & 5 & 6 \\
\hline $\begin{array}{c}\text { Alternativas } \\
\text { locacionais }\end{array}$ & 1 & 5 & 6 \\
\hline $\begin{array}{c}\text { Consideração de } \\
\text { PPPs }\end{array}$ & 1 & 5 & 6 \\
\hline Monitoramento & 1 & 5 & 6 \\
\hline Participação social & 1 & 5 & 6 \\
\hline
\end{tabular}


Tabela 22 - Adequação do EIA/RIMA para a AIA de PGMs, segundo a categoria 02 (Direito e Regulamentação).

\begin{tabular}{cccc}
\hline Critérios & Sim (Frequência) & Não (Frequência) & Total \\
\hline Impactos cumulativos & 2 & 2 & 4 \\
\hline $\begin{array}{c}\text { Alternativas } \\
\text { tecnológicas }\end{array}$ & 0 & 4 & 4 \\
\hline $\begin{array}{c}\text { Alternativas } \\
\text { locacionais }\end{array}$ & 2 & 2 & 4 \\
\hline $\begin{array}{c}\text { Consideração de } \\
\text { PPPs }\end{array}$ & 2 & 2 & 4 \\
\hline Monitoramento & 0 & 4 & 4 \\
\hline Participação social & 1 & 3 & 4 \\
\hline
\end{tabular}

Tabela 23 - Adequação do EIA/RIMA para a AIA de PGMs, segundo a categoria 03 (Ecologia).

\begin{tabular}{cccc}
\hline Critérios & Sim (Frequência) & Não (Frequência) & Total \\
\hline Impactos cumulativos & 3 & 4 & 7 \\
\hline $\begin{array}{c}\text { Alternativas } \\
\text { tecnológicas }\end{array}$ & 3 & 4 & 7 \\
\hline $\begin{array}{c}\text { Alternativas } \\
\text { locacionais }\end{array}$ & 4 & 3 & 7 \\
\hline $\begin{array}{c}\text { Consideração de } \\
\text { PPPs }\end{array}$ & 3 & 4 & 7 \\
\hline Monitoramento & 2 & 5 & 7 \\
\hline Participação social & 2 & 5 & 7 \\
\hline
\end{tabular}

Tabela 24 - Adequação do EIA/RIMA para a AIA de PGMs, segundo a categoria 04 (Meio Ambiente).

\begin{tabular}{cccc}
\hline Critérios & Sim (Frequência) & Não (Frequência) & Total \\
\hline Impactos cumulativos & 7 & 5 & 12 \\
\hline $\begin{array}{c}\text { Alternativas } \\
\text { tecnológicas }\end{array}$ & 8 & 4 & 12 \\
\hline $\begin{array}{c}\text { Alternativas } \\
\text { locacionais }\end{array}$ & 7 & 5 & 12 \\
\hline Consideração de PPPs & 8 & 4 & 12 \\
\hline Monitoramento & 8 & 4 & 12 \\
\hline Participação social & 6 & 6 & 12 \\
\hline
\end{tabular}

Tabela 25 - Adequação do EIA/RIMA para a AIA de PGMs, segundo a categoria 05 (ONGs).

\begin{tabular}{ccccc}
\hline Critérios & Sim (Frequência) & Não (Frequência) & Não sabe/Outro & Total \\
\hline $\begin{array}{c}\text { Impactos } \\
\text { cumulativos }\end{array}$ & 2 & 4 & 2 & 8 \\
\hline $\begin{array}{c}\text { Alternativas } \\
\text { tecnológicas }\end{array}$ & 3 & 3 & 2 & 8 \\
\hline $\begin{array}{c}\text { Alternativas } \\
\text { locacionais }\end{array}$ & 2 & 3 & 3 & 8 \\
\hline $\begin{array}{c}\text { Consideração de } \\
\text { PPPs }\end{array}$ & 3 & 3 & 2 & 8 \\
\hline Monitoramento & 3 & 3 & 2 & 8 \\
\hline Participação social & 3 & 3 & 2 & 8 \\
\hline
\end{tabular}


De acordo com a Tabela 20 e Gráfico 04, a maioria dos participantes perceberam a inadequação do instrumento EIA/RIMA para o cumprimento dos critérios apresentados.

O EIA foi considerado ineficiente especialmente em relação ao monitoramento e à participação social. Pode-se constatar, porém, muitas divergências de respostas, já que alguns participantes opinaram de forma favorável ao uso do EIA para atingir as questões levantadas.

$\mathrm{Na}$ categoria 01, a maioria considerou o EIA inapropriado a todos os aspectos. A categoria "Direito e Regulamentação" apresentou maiores divergências neste aspecto, apresentando metade de respostas nos aspectos "impactos cumulativos", "alternativas locacionais" e "consideração de outras PPPs". Quanto ao monitoramento e alternativas tecnológicas, todos consideraram o EIA inadequado.

Os membros da área de Ecologia pensam ser o EIA um instrumento apropriado apenas para a análise de alternativas locacionais, sendo o monitoramento e a participação social considerados seus piores aspectos.

A categoria "Meio Ambiente" considerou o EIA adequado ao cumprimento de todas as funções abordadas, com exceção da participação social, cujas opiniões foram mais divergentes (metade das respostas para as alternativas "Sim" e "Não"). Pode-se inferir que tal resultado se deu em razão de uma maior atuação dos participantes desta área em EIA/RIMAs.

As ONGs caracterizaram-se por apresentar maiores divergências de respostas, com metade dos participantes avaliando os critérios como adequados ou não. Apenas em relação aos impactos cumulativos e alternativas locacionais a maioria considerou o EIA como um instrumento inadequado. Pode-se inferir a maior diversidade de opiniões em função da heterogeneidade do grupo.

Questão 05: Em sua opinião, o instrumento Análise de Risco (AR) é adequado para a avaliação dos impactos ambientais em escala comercial de PGMs, nos seguintes aspectos?

Tabela 26 - Adequação da Análise de Risco para a AIA de PGMs (para todos os respondentes.

\begin{tabular}{cccc}
\hline Critérios & Sim & Não & Não sabe \\
\hline Impactos cumulativos & $56,7 \%$ & $29,8 \%$ & $13,5 \%$ \\
\hline $\begin{array}{c}\text { Alternativas } \\
\text { tecnológicas }\end{array}$ & $40,5 \%$ & $46 \%$ & $13,5 \%$ \\
\hline $\begin{array}{c}\text { Alternativas } \\
\text { locacionais }\end{array}$ & $40,5 \%$ & $46 \%$ & $13,5 \%$ \\
\hline $\begin{array}{c}\text { Consideração de } \\
\text { PPPs }\end{array}$ & $24,3 \%$ & $59,5 \%$ & $16,2 \%$ \\
\hline Monitoramento & $48,6 \%$ & $35,2 \%$ & $16,2 \%$ \\
\hline Participação social & $21,6 \%$ & $62,2 \%$ & $16,2 \%$ \\
\hline
\end{tabular}


Gráfico 05. Adequação da Análise de Risco para a AIA de PGMs.

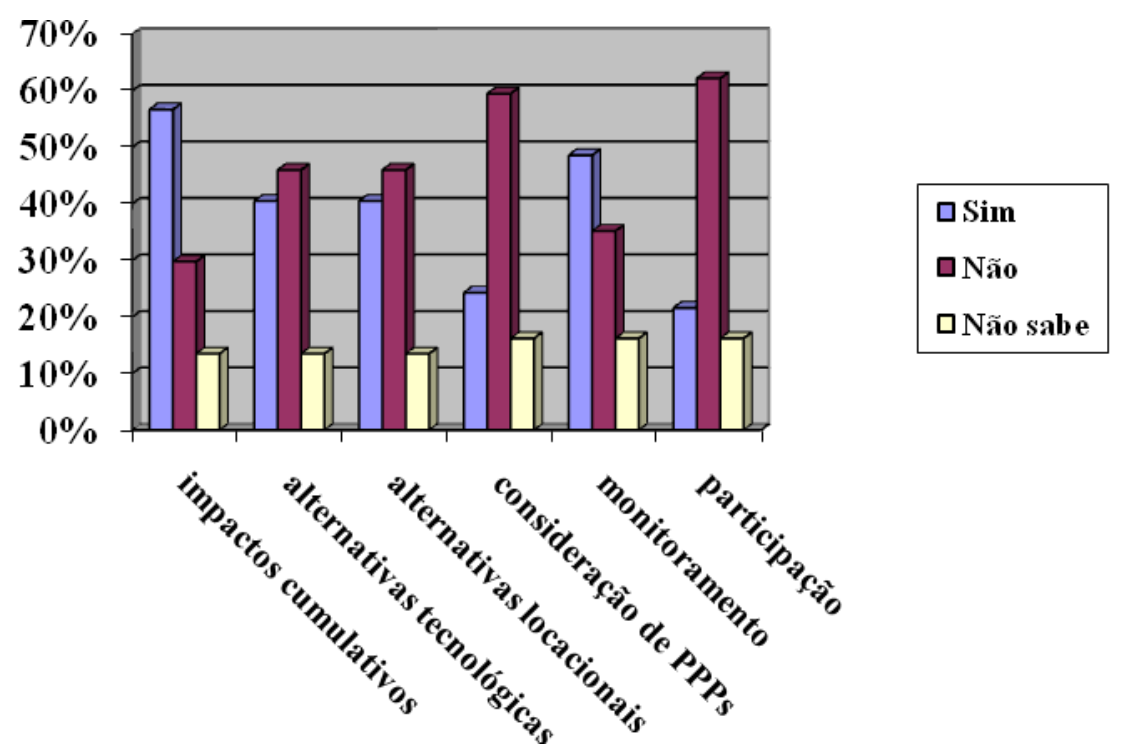

Tabela 27 - Adequação da Análise de Risco para a AIA de PGMs, segundo a categoria 01 (Biotecnologia e/ou Biossegurança).

\begin{tabular}{ccccc}
\hline Critérios & Sim (Frequência) & Não (Frequência) & Não sabe & Total \\
\hline $\begin{array}{c}\text { Impactos } \\
\text { cumulativos }\end{array}$ & 4 & 1 & 1 & 6 \\
\hline $\begin{array}{c}\text { Alternativas } \\
\text { tecnológicas }\end{array}$ & 3 & 3 & 0 & 6 \\
\hline $\begin{array}{c}\text { Alternativas } \\
\text { locacionais }\end{array}$ & 2 & 3 & 1 & 6 \\
\hline $\begin{array}{c}\text { Consideração de } \\
\text { PPPs }\end{array}$ & 2 & 4 & 0 & 6 \\
\hline Monitoramento & 4 & 2 & 0 & 6 \\
\hline Participação social & 1 & 4 & 1 & 6 \\
\hline
\end{tabular}

Tabela 28 - Adequação da Análise de Risco para a AIA de PGMs, segundo a categoria 02 (Direito e Regulamentação).

\begin{tabular}{ccccc}
\hline Critérios & Sim (Frequência) & Não (Frequência) & Não sabe & Total \\
\hline $\begin{array}{c}\text { Impactos } \\
\text { cumulativos }\end{array}$ & 1 & 3 & 0 & 4 \\
\hline $\begin{array}{c}\text { Alternativas } \\
\text { tecnológicas }\end{array}$ & 0 & 4 & 0 & 4 \\
\hline $\begin{array}{c}\text { Alternativas } \\
\text { locacionais }\end{array}$ & 1 & 3 & 0 & 4 \\
\hline $\begin{array}{c}\text { Consideração de } \\
\text { PPPs }\end{array}$ & 0 & 4 & 0 & 4 \\
\hline Monitoramento & 1 & 2 & 1 & 4 \\
\hline Participação social & 0 & 4 & 0 & 4 \\
\hline
\end{tabular}


Tabela 29 - Adequação da Análise de Risco para a AIA de PGMs, segundo a categoria 03 (Ecologia).

\begin{tabular}{ccccc}
\hline Critérios & Sim (Frequência) & Não (Frequência) & Não sabe/Outro & Total \\
\hline $\begin{array}{c}\text { Impactos } \\
\text { cumulativos }\end{array}$ & 4 & 2 & 1 & 7 \\
\hline $\begin{array}{c}\text { Alternativas } \\
\text { tecnológicas }\end{array}$ & 4 & 1 & 2 & 7 \\
\hline $\begin{array}{c}\text { Alternativas } \\
\text { locacionais }\end{array}$ & 4 & 1 & 2 & 7 \\
\hline $\begin{array}{c}\text { Consideração de } \\
\text { PPPs }\end{array}$ & 2 & 3 & 2 & 7 \\
\hline Monitoramento & 3 & 2 & 2 & 7 \\
\hline Participação social & 2 & 3 & 2 & 7 \\
\hline
\end{tabular}

Tabela 30 - Adequação da Análise de Risco para a AIA de PGMs, segundo a categoria 04 (Meio Ambiente).

\begin{tabular}{ccccc}
\hline Critérios & Sim (Frequência) & Não (Frequência) & Não sabe & Total \\
\hline $\begin{array}{c}\text { Impactos } \\
\text { cumulativos }\end{array}$ & 7 & 4 & 1 & 12 \\
\hline $\begin{array}{c}\text { Alternativas } \\
\text { tecnológicas }\end{array}$ & 3 & 8 & 1 & 12 \\
\hline $\begin{array}{c}\text { Alternativas } \\
\text { locacionais }\end{array}$ & 3 & 8 & 1 & 12 \\
\hline $\begin{array}{c}\text { Consideração de } \\
\text { PPPs }\end{array}$ & 2 & 9 & 1 & 12 \\
\hline Monitoramento & 6 & 5 & 1 & 12 \\
\hline Participação social & 1 & 10 & 1 & 12 \\
\hline
\end{tabular}

Tabela 31 - Adequação da Análise de Risco para a AIA de PGMs, segundo a categoria 05 (ONGs).

\begin{tabular}{ccccc}
\hline Critérios & Sim (Frequência) & Não (Frequência) & Não sabe & Total \\
\hline $\begin{array}{c}\text { Impactos } \\
\text { cumulativos }\end{array}$ & 5 & 1 & 2 & 8 \\
\hline $\begin{array}{c}\text { Alternativas } \\
\text { tecnológicas }\end{array}$ & 5 & 1 & 2 & 8 \\
\hline $\begin{array}{c}\text { Alternativas } \\
\text { locacionais }\end{array}$ & 5 & 1 & 2 & 8 \\
\hline $\begin{array}{c}\text { Consideração de } \\
\text { PPPs }\end{array}$ & 3 & 2 & 3 & 8 \\
\hline Monitoramento & 3 & 2 & 3 & 8 \\
\hline Participação social & 3 & 2 & 3 & 8 \\
\hline
\end{tabular}

A Análise de Risco é vista pela maioria dos respondentes como um instrumento de avaliação que cumpre ao menos dois dos critérios abordados, quais sejam, a consideração de impactos cumulativos e o monitoramento. A relevância dos objetivos de outras PPPs durante a análise de risco é o critério considerado mais crítico pelos participantes. De fato, a Normativa 05/08 da CTNBio que dispõe sobre os procedimentos de Análise de Risco não 
contempla os aspectos "alternativas locacionais e tecnológicas ", "consideração de outras PPPs" e a participação social só é permitida quando da solicitação de audiências públicas pela Comissão, como disposto na Lei de Biossegurança. No entanto, o monitoramento, apesar de exigido, deve ser realizado em até cinco anos após a finalização do plantio de PGMs, apesar de nenhuma empresa até então ter seus Planos de Monitoramento aprovados, contrariando a norma vigente. A categoria "Biotecnologia e/ou Biossegurança" considerou a AR adequada à avaliação dos impactos cumulativos e ao monitoramento, apresentando algumas divergências de opiniões quanto aos demais critérios. Pode-se inferir tal resultado pelo conhecimento de que a AR realmente não tem a atribuição de analisar os aspectos abordados, conforme a Normativa 05/08 da CTNBio. No entanto, os impactos cumulativos não se fazem presentes nesta norma. Em "Direito e Regulamentação", a maioria de seus membros considerou o instrumento inapropriado em todos os critérios levantados. Já a área de "Ecologia" apresentou maiores divergências de opiniões, com a maioria opinando sobre a adequação da AR quanto à avaliação dos impactos cumulativos, das alternativas (locacionais e tecnológicas) e o monitoramento. Esta área apresentou um maior número de respostas "Não sei”, demonstrando o desconhecimento sobre os propósitos do instrumento.

O grupo "Meio Ambiente" opinou de forma favorável ao uso da AR para a avaliação dos impactos cumulativos e a grande maioria (10 em 12 respostas) considera que a AR não é adequada à participação social. No tocante às ONGs, a maioria dos respondentes considerou a AR apropriada à consideração dos impactos cumulativos e às alternativas (tecnológicas e locacionais), com discordâncias mais significativas nos critérios "consideração de outras PPPs", "monitoramento" e "participação". Tal resultado pode ser dado em função da diversidade das organizações participantes e/ou também de um possível desconhecimento sobre o instrumento em questão.

Questão 06: Em um processo de avaliação ambiental para a liberação comercial de PGMs, qual a importância de se considerar os seguintes aspectos:

Tabela 32 - Na AIA de PGMs, qual a importância dos seguintes aspectos (para todos os respondentes):

\begin{tabular}{ccccc}
\hline Critérios & $\begin{array}{c}\text { Sem } \\
\text { importância }\end{array}$ & $\begin{array}{c}\text { Pouco } \\
\text { importante }\end{array}$ & Importante & $\begin{array}{c}\text { Muito } \\
\text { importante }\end{array}$ \\
\hline Impactos cumulativos & $2,7 \%$ & $0 \%$ & $13,5 \%$ & $83,8 \%$ \\
\hline $\begin{array}{c}\text { Opinião dos } \\
\text { interessados }\end{array}$ & $5,7 \%$ & $2,9 \%$ & $25,7 \%$ & $65,7 \%$ \\
\hline
\end{tabular}




\begin{tabular}{ccccc}
\hline Critérios & $\begin{array}{c}\text { Sem } \\
\text { importância }\end{array}$ & $\begin{array}{c}\text { Pouco } \\
\text { importante }\end{array}$ & Importante & $\begin{array}{c}\text { Muito } \\
\text { importante }\end{array}$ \\
\hline $\begin{array}{c}\text { Alternativas } \\
\text { tecnológicas }\end{array}$ & $18,9 \%$ & $2,7 \%$ & $13,5 \%$ & $64,9 \%$ \\
\hline Outras PPPs & $10,8 \%$ & $0 \%$ & $27 \%$ & $62,2 \%$ \\
\hline $\begin{array}{c}\text { Alternativas } \\
\text { locacionais }\end{array}$ & $11,4 \%$ & $11,4 \%$ & $14,3 \%$ & $62,9 \%$ \\
\hline $\begin{array}{c}\text { Plano de } \\
\text { monitoramento }\end{array}$ & $2,8 \%$ & $2,8 \%$ & $22,2 \%$ & $72,2 \%$ \\
\hline
\end{tabular}

Gráfico 06. Na AIA de PGMs, qual a importância dos seguintes aspectos (para todos os respondentes):

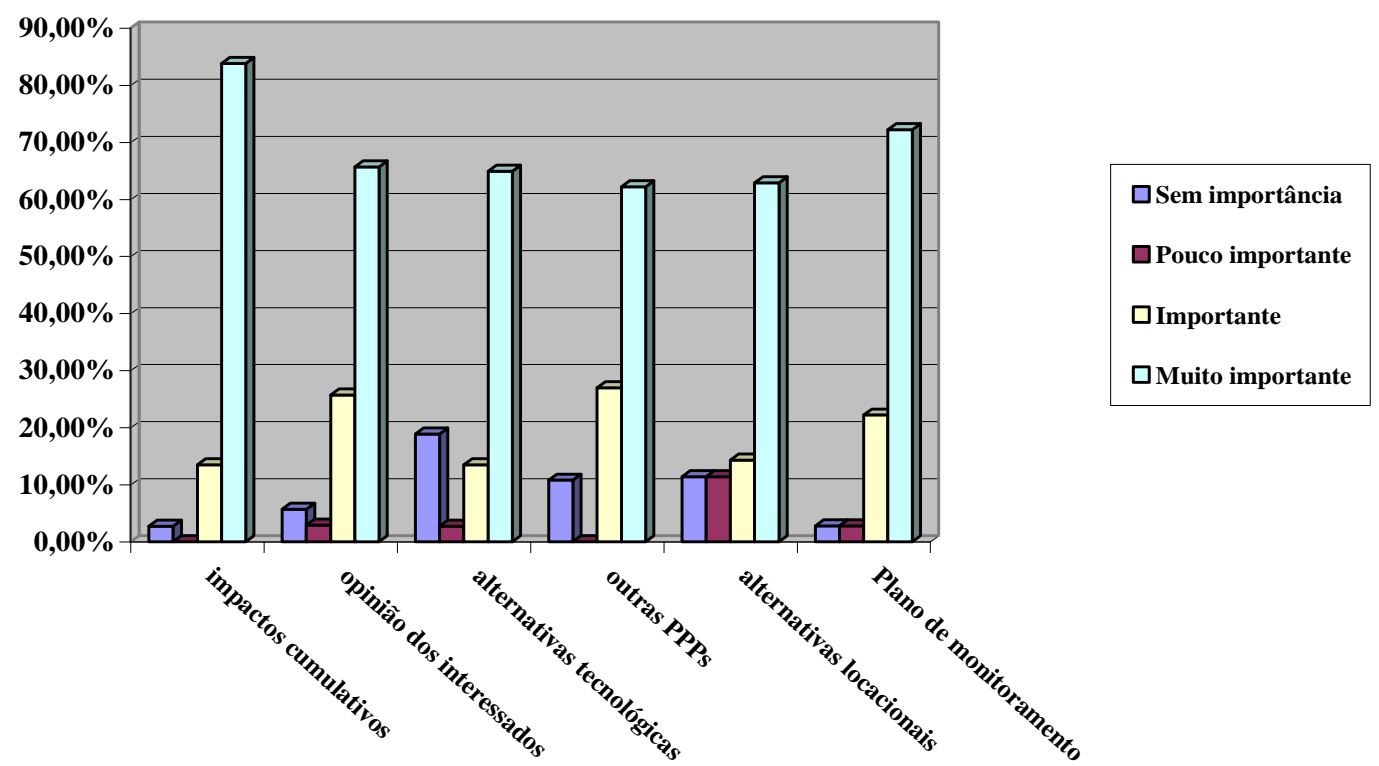

Tabela 33 - Na AIA de PGMs, qual a importância dos seguintes aspectos, segundo a categoria 01 (Biotecnologia e/ou Biossegurança):

\begin{tabular}{cccccc}
\hline Critérios & $\begin{array}{c}\text { Sem } \\
\text { importância } \\
\text { (Frequência) }\end{array}$ & $\begin{array}{c}\text { Pouco } \\
\text { importante } \\
\text { (Frequência) }\end{array}$ & $\begin{array}{c}\text { Importante } \\
\text { (Frequência) }\end{array}$ & $\begin{array}{c}\text { Muito } \\
\text { importante } \\
\text { (Frequência) }\end{array}$ & Total \\
\hline $\begin{array}{c}\text { Impactos } \\
\text { cumulativos }\end{array}$ & 1 & 0 & 2 & 3 & 6 \\
\hline $\begin{array}{c}\text { Opinião dos } \\
\text { interessados }\end{array}$ & 2 & 1 & 3 & 0 & 6 \\
\hline $\begin{array}{c}\text { Alternativas } \\
\text { tecnológicas }\end{array}$ & 5 & 0 & 1 & 0 & 6 \\
\hline Outras PPPs & 2 & 0 & 4 & 0 & 6 \\
\hline $\begin{array}{c}\text { Alternativas } \\
\text { locacionais }\end{array}$ & 2 & 2 & 0 & 2 & 6 \\
\hline $\begin{array}{c}\text { Plano de } \\
\text { monitoramento }\end{array}$ & 1 & 1 & 3 & 1 & 6 \\
\hline
\end{tabular}


Tabela 34 - Na AIA de PGMs, qual a importância dos seguintes aspectos, segundo a categoria 02 (Direito e Regulamentação):

\begin{tabular}{|c|c|c|c|c|c|}
\hline Critérios & $\begin{array}{c}\text { Sem } \\
\text { importância } \\
\text { (Frequência) }\end{array}$ & $\begin{array}{c}\text { Pouco } \\
\text { importante } \\
\text { (Frequência) }\end{array}$ & $\begin{array}{l}\text { Importante } \\
\text { (Frequência) }\end{array}$ & $\begin{array}{c}\text { Muito } \\
\text { importante } \\
\text { (Frequência) }\end{array}$ & Total \\
\hline $\begin{array}{l}\text { Impactos } \\
\text { cumulativos }\end{array}$ & 0 & 0 & 1 & 3 & 4 \\
\hline $\begin{array}{l}\text { Opinião dos } \\
\text { interessados }\end{array}$ & 0 & 0 & 1 & 3 & 4 \\
\hline $\begin{array}{l}\text { Alternativas } \\
\text { tecnológicas }\end{array}$ & 0 & 0 & 0 & 4 & 4 \\
\hline Outras PPPs & 0 & 0 & 0 & 4 & 4 \\
\hline $\begin{array}{l}\text { Alternativas } \\
\text { locacionais }\end{array}$ & 0 & 0 & 0 & 4 & 4 \\
\hline $\begin{array}{c}\text { Plano de } \\
\text { monitoramento }\end{array}$ & 0 & 0 & 2 & 2 & 4 \\
\hline
\end{tabular}

Tabela 35 - Na AIA de PGMs, qual a importância dos seguintes aspectos, segundo a categoria 03 (Ecologia):

\begin{tabular}{cccccc}
\hline Critérios & $\begin{array}{c}\text { Sem } \\
\text { importância } \\
\text { (Frequência) }\end{array}$ & $\begin{array}{c}\text { Pouco } \\
\text { importante } \\
\text { (Frequência) }\end{array}$ & $\begin{array}{c}\text { Importante } \\
\text { (Frequência) }\end{array}$ & $\begin{array}{c}\text { Muito } \\
\text { importante } \\
\text { (Frequência) }\end{array}$ & Total \\
\hline $\begin{array}{c}\text { Impactos } \\
\text { cumulativos }\end{array}$ & 0 & 0 & 0 & 7 & 7 \\
\hline $\begin{array}{c}\text { Opinião dos } \\
\text { interessados }\end{array}$ & 0 & 0 & 2 & 5 & 7 \\
\hline $\begin{array}{c}\text { Alternativas } \\
\text { tecnológicas }\end{array}$ & 1 & 0 & 2 & 4 & 7 \\
\hline Outras PPPs & 2 & 0 & 1 & 6 & 7 \\
\hline $\begin{array}{c}\text { Alternativas } \\
\text { locacionais }\end{array}$ & 1 & 0 & 1 & 6 & 7 \\
\hline $\begin{array}{c}\text { Plano de } \\
\text { monitoramento }\end{array}$ & 0 & 0 & 1 & & 7 \\
\hline
\end{tabular}

Tabela 36 - Na AIA de PGMs, qual a importância dos seguintes aspectos, segundo a categoria 04 (Meio Ambiente):

\begin{tabular}{cccccc}
\hline Critérios & $\begin{array}{c}\text { Sem } \\
\text { importância }\end{array}$ & $\begin{array}{c}\text { Pouco } \\
\text { importante }\end{array}$ & Importante & $\begin{array}{c}\text { Muito } \\
\text { importante }\end{array}$ & Total \\
\hline $\begin{array}{c}\text { Impactos } \\
\text { cumulativos }\end{array}$ & 0 & 0 & 1 & 11 & 12 \\
\hline $\begin{array}{c}\text { Opinião dos } \\
\text { interessados }\end{array}$ & 0 & 0 & 3 & 9 & 12 \\
\hline $\begin{array}{c}\text { Alternativas } \\
\text { tecnológicas }\end{array}$ & 1 & 1 & 2 & 8 & 12 \\
\hline Outras PPPs & 0 & 0 & 4 & 8 & 12 \\
\hline $\begin{array}{c}\text { Alternativas } \\
\text { locacionais }\end{array}$ & 1 & 2 & 2 & 7 & 12 \\
\hline $\begin{array}{c}\text { Plano de } \\
\text { monitoramento }\end{array}$ & 0 & 0 & 2 & 10 & 12 \\
\hline
\end{tabular}


Tabela 37 - Na AIA de PGMs, qual a importância dos seguintes aspectos, segundo a categoria 05 (ONGs):

\begin{tabular}{cccccc}
\hline Critérios & $\begin{array}{c}\text { Sem } \\
\text { importância } \\
\text { (Frequência) }\end{array}$ & $\begin{array}{c}\text { Pouco } \\
\text { importante } \\
\text { (Frequência) }\end{array}$ & $\begin{array}{c}\text { Importante } \\
\text { (Frequência) }\end{array}$ & $\begin{array}{c}\text { Muito } \\
\text { importante } \\
\text { (Frequência) }\end{array}$ & Total \\
\hline $\begin{array}{c}\text { Impactos } \\
\text { cumulativos }\end{array}$ & 0 & 0 & 1 & 7 & 8 \\
\hline $\begin{array}{c}\text { Opinião dos } \\
\text { interessados }\end{array}$ & 0 & 0 & 0 & 8 & 8 \\
\hline $\begin{array}{c}\text { Alternativas } \\
\text { tecnológicas }\end{array}$ & 0 & 0 & 0 & 8 & 8 \\
\hline Outras PPPs & 0 & 0 & 1 & 7 & 8 \\
\hline $\begin{array}{c}\text { Alternativas } \\
\text { locacionais }\end{array}$ & 0 & 0 & 2 & 8 & 8 \\
\hline $\begin{array}{c}\text { Plano de } \\
\text { monitoramento }\end{array}$ & 0 & 0 & 0 & & 8 \\
\hline
\end{tabular}

A maioria dos respondentes considera importantes os critérios indicados na Tabela 32 e seu correspondente Gráfico 06 em uma avaliação de impactos de PGMs, quais sejam: os impactos cumulativos; a opinião dos agentes sociais interessados; as alternativas locacionais e tecnológicas, os objetivos e metas de Políticas, Planos e Programas relacionados e o monitoramento ambiental, sendo os critérios melhor pontuados a "avaliação dos impactos cumulativos" e o "monitoramento"

Em relação aos grupos analisados, os especialistas em biotecnologia e/ou biossegurança consideraram importantes a avaliação dos impactos cumulativos, outras PPPs e o Plano de monitoramento nos processos de avaliação para a liberação de OGMs, enquanto que a existência de alternativas tecnológicas obteve a maior porcentagem de irrelevância, provavelmente em função da área de atuação dos participantes que, em sua maioria, desenvolvem PGMs. A categoria "Direito e Regulamentação" foi praticamente unânime em considerar todos os critérios apontados como sendo "importantes" ou "muito importantes". O mesmo se deu com a demais categorias.

Questão 07. Como você avalia os seguintes aspectos do processo decisório envolvendo a liberação em escala comercial para o plantio de PGMs no Brasil, sendo:

1 = totalmente insatisfatório; 2 = insatisfatório; 3 = satisfatório e 4= bastante satisfatório. 
Tabela 38 - Avaliação do processo decisório sobre PGMs no Brasil (para todos os respondentes):

\begin{tabular}{ccccc}
\hline Critérios & $\begin{array}{c}\text { Totalmente } \\
\text { insatisfatório }\end{array}$ & Insatisfatório & Satisfatório & $\begin{array}{c}\text { Totalmente } \\
\text { satisfatório }\end{array}$ \\
\hline $\begin{array}{c}\text { Coordenação } \\
\text { institucional }\end{array}$ & $63,9 \%$ & $8,3 \%$ & $16,7 \%$ & $11,1 \%$ \\
\hline Legitimidade & $63,9 \%$ & $19,4 \%$ & $2,8 \%$ & $13,9 \%$ \\
\hline Transparência & $61,1 \%$ & $19,4 \%$ & $5,6 \%$ & $13,9 \%$ \\
\hline $\begin{array}{c}\text { Inserção de } \\
\text { aspectos } \\
\text { ambientais }\end{array}$ & $52,8 \%$ & $27,8 \%$ & $5,6 \%$ & $13,9 \%$ \\
\hline $\begin{array}{c}\text { Inserção de } \\
\text { aspectos sociais }\end{array}$ & $66,7 \%$ & $16,7 \%$ & $8,3 \%$ & $8,3 \%$ \\
\hline $\begin{array}{c}\text { Inserção de } \\
\text { aspectos } \\
\text { econômicos }\end{array}$ & $41,7 \%$ & $19,4 \%$ & $19,4 \%$ & $19,4 \%$ \\
\hline $\begin{array}{c}\text { Implementação } \\
\text { do SIB }\end{array}$ & $67,6 \%$ & $17,6 \%$ & $5,9 \%$ & $8,8 \%$ \\
\hline $\begin{array}{c}\text { Fiscalização } \\
\text { Adoção de } \\
\text { medidas } \\
\text { preventivas }\end{array}$ & $69,4 \%$ & $13,9 \%$ & $2,8 \%$ & $13,9 \%$ \\
\hline $\begin{array}{c}\text { Análise de } \\
\text { outras PPPs }\end{array}$ & $66,7 \%$ & $16,7 \%$ & $5,6 \%$ & $11,1 \%$ \\
\hline
\end{tabular}

Gráfico 07. Avaliação do processo decisório sobre PGMs no Brasil, segundo os critérios (para todos os respondentes):

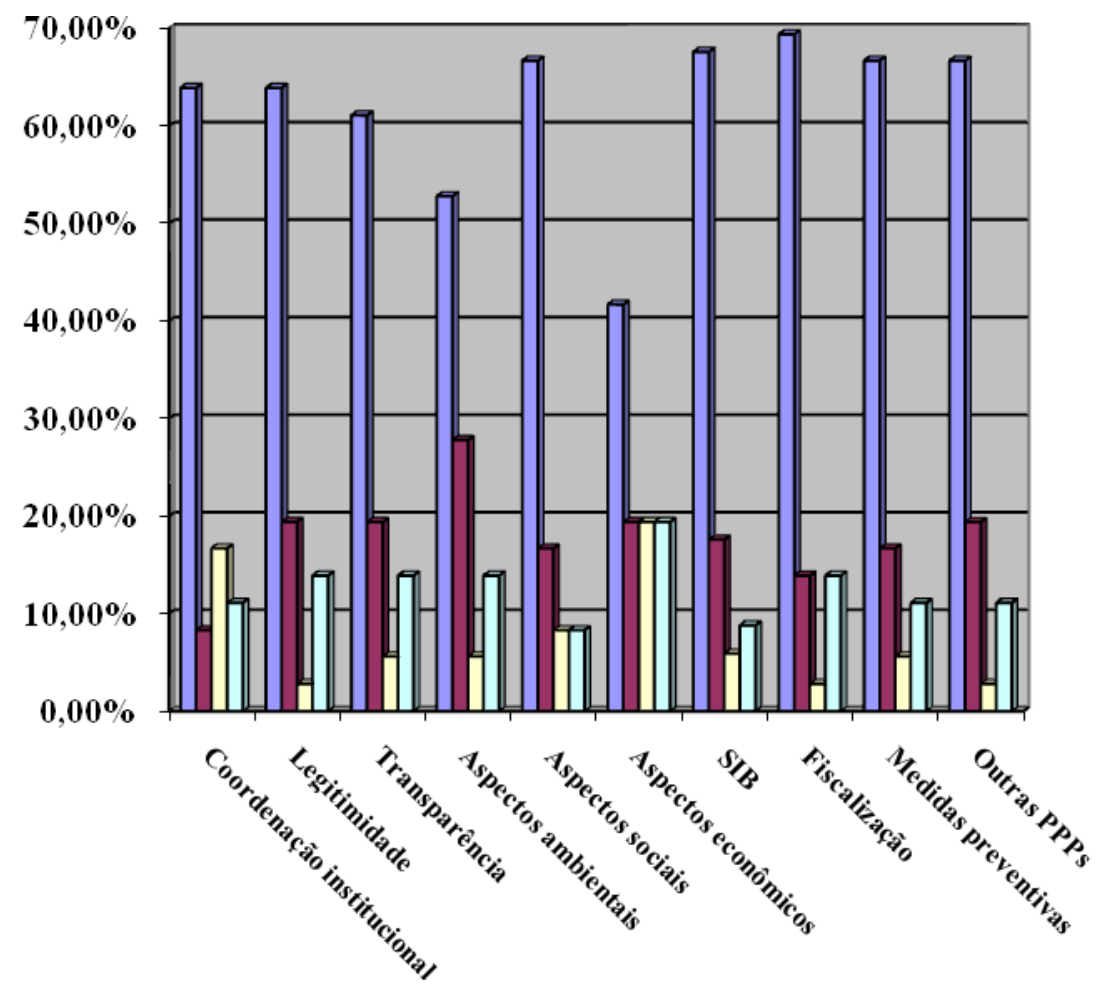

\begin{tabular}{|c|}
\hline $\begin{array}{c}\text { 口Totalmente } \\
\text { insatisfatório } \\
\text { 口Insatisfatório }\end{array}$ \\
口Satisfatório \\
$\begin{array}{c}\text { QTotalmente } \\
\text { satisfatório }\end{array}$ \\
\hline
\end{tabular}


Tabela 39. Avaliação do processo decisório sobre PGMs no Brasil, segundo a categoria 01 (Biotecnologia e/ou Biossegurança):

\begin{tabular}{cccccc}
\hline Critérios & $\begin{array}{c}\text { Totalmente } \\
\text { insatisfatório }\end{array}$ & Insatisfatório & Satisfatório & $\begin{array}{c}\text { Totalmente } \\
\text { satisfatório }\end{array}$ & Total \\
\hline $\begin{array}{c}\text { Coordenação } \\
\text { institucional }\end{array}$ & 1 & 0 & 2 & 3 & 6 \\
\hline Legitimidade & 1 & 1 & 0 & 4 & 6 \\
\hline Transparência & 1 & 0 & 2 & 3 & 6 \\
\hline $\begin{array}{c}\text { Inserção de } \\
\text { aspectos } \\
\text { ambientais }\end{array}$ & 1 & 1 & 2 & 2 & 6 \\
\hline $\begin{array}{c}\text { Inserção de } \\
\text { aspectos sociais }\end{array}$ & 2 & 1 & 1 & 3 & 6 \\
\hline $\begin{array}{c}\text { Inserção de } \\
\text { aspectos } \\
\text { econômicos }\end{array}$ & 1 & 1 & 1 & & 6 \\
\hline $\begin{array}{c}\text { Implementação } \\
\text { do SIB }\end{array}$ & 2 & 2 & 1 & 2 & 6 \\
\hline Fiscalização & 2 & 1 & 1 & 2 & 6 \\
\hline $\begin{array}{c}\text { Adoção de } \\
\text { medidas } \\
\text { preventivas }\end{array}$ & 1 & 2 & 1 & 2 & 6 \\
\hline $\begin{array}{c}\text { Análise de } \\
\text { outras PPPs }\end{array}$ & 1 & 3 & 0 & & 6 \\
\hline
\end{tabular}

Tabela 40 - Avaliação do processo decisório sobre PGMs no Brasil, segundo a categoria 02 (Direito e Regulamentação):

\begin{tabular}{cccccc}
\hline Critérios & $\begin{array}{c}\text { Totalmente } \\
\text { insatisfatório }\end{array}$ & Insatisfatório & Satisfatório & $\begin{array}{c}\text { Totalmente } \\
\text { satisfatório }\end{array}$ & Total \\
\hline $\begin{array}{c}\text { Coordenação } \\
\text { institucional }\end{array}$ & 4 & 0 & 0 & 0 & 4 \\
\hline Legitimidade & 4 & 1 & 0 & 0 & 4 \\
\hline Transparência & 4 & 0 & 0 & 0 & 4 \\
\hline $\begin{array}{c}\text { Inserção de } \\
\text { aspectos } \\
\text { ambientais }\end{array}$ & 3 & 1 & 0 & 0 & 4 \\
\hline $\begin{array}{c}\text { Inserção de } \\
\text { aspectos sociais }\end{array}$ & 4 & 0 & 0 & 0 & 4 \\
\hline $\begin{array}{c}\text { Inserção de } \\
\text { aspectos } \\
\text { econômicos }\end{array}$ & 3 & 1 & 0 & 0 & 4 \\
\hline $\begin{array}{c}\text { Implementação } \\
\text { do SIB }\end{array}$ & 3 & 1 & 0 & 0 & 4 \\
\hline $\begin{array}{c}\text { Fiscalização } \\
\begin{array}{c}\text { Adoção de } \\
\text { medidas } \\
\text { preventivas }\end{array}\end{array}$ & 4 & 0 & 0 & 0 & 4 \\
\hline $\begin{array}{c}\text { Análise de } \\
\text { outras PPPs }\end{array}$ & 4 & $0 \%$ & 0 & 0 & 4 \\
\hline
\end{tabular}


Tabela 41 - Avaliação do processo decisório sobre PGMs no Brasil, segundo a categoria 03 (Ecologia):

\begin{tabular}{|c|c|c|c|c|c|}
\hline Critérios & $\begin{array}{c}\text { Totalmente } \\
\text { insatisfatório }\end{array}$ & Insatisfatório & Satisfatório & $\begin{array}{l}\text { Totalmente } \\
\text { satisfatório }\end{array}$ & Total \\
\hline $\begin{array}{l}\text { Coordenação } \\
\text { institucional }\end{array}$ & 3 & 1 & 3 & 0 & 7 \\
\hline Legitimidade & 4 & 2 & 1 & 0 & 7 \\
\hline Transparência & 3 & 4 & 0 & 0 & 7 \\
\hline $\begin{array}{l}\text { Inserção de } \\
\text { aspectos } \\
\text { ambientais }\end{array}$ & 3 & 4 & 0 & 0 & 7 \\
\hline $\begin{array}{c}\text { Inserção de } \\
\text { aspectos sociais }\end{array}$ & 4 & 3 & 0 & 0 & 7 \\
\hline $\begin{array}{l}\text { Inserção de } \\
\text { aspectos } \\
\text { econômicos }\end{array}$ & 2 & 1 & 1 & 2 & 7 \\
\hline $\begin{array}{c}\text { Implementação } \\
\text { do SIB }\end{array}$ & 6 & 0 & 0 & 1 & 7 \\
\hline Fiscalização & 5 & 1 & 0 & 1 & 7 \\
\hline $\begin{array}{l}\text { Adoção de } \\
\text { medidas } \\
\text { preventivas }\end{array}$ & 3 & 3 & 1 & 0 & 7 \\
\hline $\begin{array}{c}\text { Análise de } \\
\text { outras PPPs }\end{array}$ & 4 & 2 & 1 & 0 & 7 \\
\hline
\end{tabular}

Tabela 42 - Avaliação do processo decisório sobre PGMs no Brasil, segundo a categoria 04 (Meio Ambiente):

\begin{tabular}{|c|c|c|c|c|c|}
\hline Critérios & $\begin{array}{c}\text { Totalmente } \\
\text { insatisfatório }\end{array}$ & Insatisfatório & Satisfatório & $\begin{array}{l}\text { Totalmente } \\
\text { satisfatório }\end{array}$ & Total \\
\hline $\begin{array}{l}\text { Coordenação } \\
\text { institucional }\end{array}$ & 8 & 2 & 1 & 1 & 12 \\
\hline Legitimidade & 9 & 2 & 0 & 1 & 12 \\
\hline Transparência & 8 & 2 & 0 & 2 & 12 \\
\hline $\begin{array}{l}\text { Inserção de } \\
\text { aspectos } \\
\text { ambientais }\end{array}$ & 6 & 3 & 0 & 3 & 12 \\
\hline $\begin{array}{c}\text { Inserção de } \\
\text { aspectos sociais }\end{array}$ & 7 & 2 & 2 & 1 & 12 \\
\hline $\begin{array}{l}\text { Inserção de } \\
\text { aspectos } \\
\text { econômicos }\end{array}$ & 2 & 4 & 5 & 1 & 12 \\
\hline $\begin{array}{c}\text { Implementação } \\
\text { do SIB }\end{array}$ & 7 & 3 & 1 & 1 & 12 \\
\hline Fiscalização & 9 & 1 & 0 & 2 & 12 \\
\hline $\begin{array}{l}\text { Adoção de } \\
\text { medidas } \\
\text { preventivas }\end{array}$ & 8 & 2 & 0 & 2 & 12 \\
\hline $\begin{array}{c}\text { Análise de } \\
\text { outras PPPs }\end{array}$ & 8 & 2 & 1 & 1 & 12 \\
\hline
\end{tabular}


Tabela 43 - Avaliação do processo decisório sobre PGMs no Brasil, segundo a categoria 05 (ONGs):

\begin{tabular}{|c|c|c|c|c|c|}
\hline Critérios & $\begin{array}{c}\text { Totalmente } \\
\text { insatisfatório }\end{array}$ & Insatisfatório & Satisfatório & $\begin{array}{l}\text { Totalmente } \\
\text { satisfatório }\end{array}$ & Total \\
\hline $\begin{array}{l}\text { Coordenação } \\
\text { institucional }\end{array}$ & 8 & 0 & 0 & 0 & 8 \\
\hline Legitimidade & 7 & 1 & 0 & 0 & 8 \\
\hline Transparência & 7 & 1 & 0 & 0 & 8 \\
\hline $\begin{array}{l}\text { Inserção de } \\
\text { aspectos } \\
\text { ambientais }\end{array}$ & 7 & 1 & 0 & 0 & 8 \\
\hline $\begin{array}{c}\text { Inserção de } \\
\text { aspectos sociais }\end{array}$ & 8 & 0 & 0 & 0 & 8 \\
\hline $\begin{array}{l}\text { Inserção de } \\
\text { aspectos } \\
\text { econômicos }\end{array}$ & 8 & 0 & 0 & 0 & 8 \\
\hline $\begin{array}{l}\text { Implementação } \\
\text { do SIB }\end{array}$ & 8 & 0 & 0 & 0 & 8 \\
\hline Fiscalização & 8 & 0 & 0 & 0 & 8 \\
\hline $\begin{array}{l}\text { Adoção de } \\
\text { medidas } \\
\text { preventivas }\end{array}$ & 8 & 0 & 0 & 0 & 8 \\
\hline $\begin{array}{l}\text { Análise de } \\
\text { outras PPPs }\end{array}$ & 8 & 0 & 0 & 0 & 8 \\
\hline
\end{tabular}

A tabela 38 e o Gráfico correspondente 07 demonstram que a maioria dos respondentes considera totalmente insatisfatório a condução do processo decisório sobre a liberação de PGMs no Brasil, de acordo com os critérios apontados.

Sobre as categorias especificamente, o grupo de "Biotecnologia e/ou Biossegurança" foi o que mais se mostrou satisfeito com o modo de condução das decisões sobre PGMs, considerando insatisfatórios os seguintes aspectos: "legitimidade", "existência do SIB" e “consideração de outras PPPs". Já nos critérios "aspectos sociais", "fiscalização" e "medidas preventivas", as opiniões foram divergentes. A categoria "Direito e Regulamentação" considerou todos os aspectos como insatisfatórios. O mesmo se deu em "Ecologia", com exceção para a consideração dos "aspectos econômicos", sendo este o critério em que metade dos respondentes da categoria "Meio Ambiente" considerou como satisfatório. Já as ONGs consideraram todos os critérios como insatisfatórios.

Questão 08. Você conhece algum instrumento de avaliação de impacto ambiental que aborde os aspectos de "a" até "f" contemplados nas questões 4 e 5 em relação ao plantio em escala comercial de PGMs? 
De modo geral, os participantes de todas as categorias demonstraram um desconhecimento a respeito de potenciais instrumentos de avaliação de impactos ambientais que levem em conta os fatores apontados nas questões 04 e 05 . No entanto, alguns foram apontados, quais sejam:

- Projeto GMO Era: 3 respondentes, cada um pertencente à uma das categorias 1, 2 e5.

- Resoluções Normativas da CTNBio: 2 respondentes da categoria 1.

- EIA/RIMA: 1 respondente da categoria 1.

- Análise de Risco: 1 respondente da categoria 4.

- Matriz de Leopold: 1 respondente da categoria 1.

- Normas da OMS e da FAO: 1 respondente da categoria 1

- AAE: 1 representante da categoria 2 e três da categoria 4.

- Zoneamento ecológico-econômico: 1 respondente da categoria 4.

- Avaliação Ambiental Integrada: 1 respondente da categoria 4.

- Não sabe: 1 respondente da categoria 1;2 da categoria 2; 3 da categoria 3;8 da categoria 4 e 7 da categoria 5 .

A seguir, algumas respostas discursivas serão apresentadas por categorias:

Categoria 01:

São vários, mas a avaliação de impacto ambiental deveria ser caso-a-caso e considerar o conhecimento acumulado da comunidade científica e dos órgãos ambientais sobre os diversos biomas e condições edafoclimáticas.

(RESPONDENTE 05)

OMS e FAO são considerados os melhores instrumentos de avaliação de diferentes aspectos em relação a esta tecnologia. Parece-me meio hipócrita discutir com a "sociedade" questões extremamente técnicas.

(RESPONDENTE 02)

Categoria 02:

Não. Esses instrumentos [EIA/RIMA e AR] não são voltados para o estudo de alternativas tecnológicas. E muito menos para o monitoramento póscomercial. A avaliação de impacto ambiental deve sempre ser prévia ao impacto a ser avaliado e o monitoramento pós-comercial pressupõe a realização de controle posterior à autorização para comercialização do OGM.

(RESPONDENTE 07) 
Categoria 03:

A Avaliação Ambiental Estratégica (AAE), uma nova ferramenta de diagnóstico do impacto ambiental, difere do Estudo de Impacto Ambiental (EIA) e do Relatório de Impacto Ambiental (RIMA), por ter como objetivo principal avaliar as implicações das políticas, planos e programas (PPPs) no contexto das dimensões econômica, ambiental e social [...].

(RESPONDENTE 08)

O único instrumento de avaliação que existe é a experimentação científica visando tal avaliação.O problema dos relatórios e análises de risco atualmente feitos reside no fato de não se basearem em experimentação in situ e se basearem em estudos normalmente não delineados para esta finalidade primária. Além disto, os resultados gerados em tal experimentação e a avaliação de risco posterior deveriam ser contrapostos ao posicionamento político-cultural em relação ao assunto levando em conta a relação custo/beneficio advinda da tecnologia em questão. Não é sequer necessário relatório de impacto ambiental, para saber que o mesmo existe para PGMs (senão isto não seria sequer um método de controle de pragas) o nível de impacto aceitável é que seria a questão fundamental a ser debatida.

(RESPONDENTE 15)

Categoria 04:

$\mathrm{Na}$ verdade existe uma total falta de instrumentos que possam avaliar de maneira compreensiva todos os aspectos arrolados entre "a" e "f". O fato é que teríamos que considerar outras formas de avaliação e mensuração dos efeitos globais da transgenia, o que parece não estar nem em questão no momento.

(RESPONDENTE 18)

[...] todo e qualquer instrumento neste sentido precisa ser aprimorado no sentido de garantir a maior presença do controle social e isto exige uma política pública de educação ambiental popular permanente, continuada, articulada e com a totalidade da população. Pelo que lembro dos EIA/RIMAs, eles previam muito do demandado nos itens "a" e "f", no entanto muito do colocado no papel ficava apenas para "inglês ver".

(RESPONDENTE 25)

Não conheço. Nem Estudos de Impacto Ambiental e seus respectivos Relatórios de Impacto ambiental tem continuidade e abrangência para fazer isto, nem a Análise de Risco. Com certeza, para elaborar trabalhos eficientes nesta área são necessários novos instrumentos. Os EIA-RIMAs estão burocratizados e não tem respondido às necessidades sociais em áreas muito mais simples. Certamente não respondem adequadamente a tarefas desta complexidade.

(RESPONDENTE 26)

A Avaliação Ambiental Estratégica (AAE) me parece ser um instrumento mais adequado para a avaliação de impacto ambiental no caso de liberação 
para plantio em escala comercial de PGMs, em função da escala, interfaces, impactos cumulativos e grau de incerteza envolvidos.

(RESPONDENTE 29)

Categoria 05:

O importante não é propriamente o instrumento, mas QUEM FAZ E QUEM PAGA A AVALIAÇÃO, ou seja, o problema do CONFLITO DE INTERESSES. Se a avaliação não é confiável, mesmo que muitas - ou todas - as facetas consideradas sejam importantes, COMO É O CASO, a análise fica prejudicada.

(RESPONDENTE 33)

Desconheço completamente - minha convicção é a de que estas exigências, do ponto de vista do interesse das empresas, atrapalhariam seus planos de expansão e domínio

(RESPONDENTE 37)

Analisando-se estes comentários, percebe-se que a maioria dos participantes desconhece instrumentos de avaliação de impactos ambientais e sócio-econômicos abrangentes, sendo uma preocupação em seu desenvolvimento por todas as categorias, com exceção da primeira, com alguns de seus representantes considerando a análise de risco (também presentes nas normativas da FAO, da OMS e da CTNBio) e o EIA/RIMA ferramentas suficientes para tal. Outros instrumentos considerados foram o zoneamento ecológico-econômico, regulamentado pela Resolução CONAMA e a Avaliação Ambiental Estratégica, ainda não regulamentada no país, de conhecimento das categorias de Meio Ambiente e Regulamentação e Direito.

No tocante à participação social, percebe-se sua maior demanda nas tomadas de decisão por parte dos respondentes de todas as categorias, excetuando-se a primeira. É provável, como demonstrado na questão 07 , que este fato se dá por uma percepção da falta destes princípios nos processos decisórios envolvendo a liberação de PGMs no Brasil.

Questão 09. Utilize o espaço a seguir para fazer considerações que julga pertinentes e importantes.

Os especialistas em biotecnologia e/ou biossegurança vêem a questão das PGMs de forma mais técnica, sendo menos inclinados à aceitar a participação da sociedade nas discussões, pois a consideram manipulada por ideologias não dotadas de conhecimento 
técnico. Além disto, atêm-se ao Princípio da Equivalência Substancial, premissa que justifica a ausência de estudos sobre impactos, já que os transgênicos são considerados idênticos aos convencionais, não havendo a necessidade, portanto, de rotulagem. Apenas um especialista que atua exclusivamente na área de biossegurança e não no desenvolvimento de OGMs apresentou argumentos opostos. Dentre as opiniões mais representativas, podem-se citar: “[...] espera-se que num futuro não muito distante, uma vez que a biossegurança de uma PGM for aceita (liberada pela CTNBio) não seja mais necessário rotular o produto no supermercado" (RESPONDENTE 01). Alguns comentários podem ser citados:

[...] Enquanto ONGs internacionais trabalham no Brasil defendendo as agendas de países europeus, alguns brasileiros inocentes que não conhecem o assunto colaboram com estas agendas [...]. Existe uma enorme convergência na comunidade científica em relação à segurança de variedades GM. Academias de Ciências do Brasil, Terceiro Mundo, México, Itália, EUA, OMS, FAO entre outras asseguram que estas variedades são seguras.

(RESPONDENTE 02)

[...] Infelizmente é uma tecnologia muito discriminada pela ignorância de muitas pessoas, inclusive de muitos técnicos. Também é alvo de ataques ideológicos [...] o sistema de tomada de decisão para a liberação comercial de OGMs no Brasil está chegando perto do que deveria ser. Mas estamos demorando muito para decidir sobre a liberação de produtos que já estão sendo plantados sem problemas em vários países há muitos anos. [...] A decisão [...] deve ser tomada por técnicos com experiência na matéria e não por juízes ou promotores. [...] Não podemos deixar que leigos decidam sobre um assunto que não conhecem, como aconteceu muitas vezes. [...] O cultivo de OGMs no Brasil é uma questão basicamente técnica e econômica, mas tem sido tratada de forma ideológica [...]

(RESPONDENTE 03)

[...] se você mistura soja transgênica com não transgênica, a não transgênica vira transgênica para efeito de propriedade industrial . Resumindo, a empresa recebe royalties da soja não transgênica, o verdadeiro "negócio da China".

(RESPONDENTE 05)

Os especialistas em Direito e Regulamentação questionam a ineficácia do Poder Público em avaliar os potenciais riscos ambientais e sócio-econômicos ocasionados com a liberação de OGMs, além da falta de participação da sociedade nos processos decisórios. Alguns respondentes opinaram da seguinte forma a este respeito: "A Lei de Biossegurança foi alterada para assegurar a concentração de poderes na CTNBio e permitir a liberação de OGM 
sem a necessária discussão com a sociedade e mesmo como outros órgãos estatais" (RESPONDENTE 10). Outro participante levantou as seguintes questões:

O Sistema Nacional de Biossegurança é hoje um simulacro discursivo voltado a organizar a irresponsabilidade do Poder Público. Essa situação não pode se manter por muito tempo sem prejuízo para o meio ambiente e para os agentes sociais e econômicos envolvidos, vez que: a-) o banimento dos OGMs é hipótese inviável e indesejável do ponto de vista tecnocientífico; b-) a ineficácia das normas de controle não reduz os riscos inerentes às novas tecnologias.

(RESPONDENTE 07)

De modo geral, os participantes da categoria "Ecologia" defenderam uma maior participação social no assunto em questão, a fim de que as decisões não atendam unicamente os interesses do agronegócio e das multinacionais produtoras de OGMs. Além disto, acreditam que questões estratégicas para o país devem ser consideradas, não reduzindo as análises a somente aspectos técnicos Algumas opiniões representativas podem ser citadas:

A decisão sobre a pesquisa e liberação de OGMs no Brasil é tendenciosa, pois a CTNBio é composta por pesquisadores que reduzem a questão à técnica, muitos deles com interesses diretos na área privada, sem maiores preocupações com as questões ecológicas, de saúde e meio ambiente, às questões políticas e de soberania.

(RESPONDENTE 12)

[...] são necessários mais estudos avaliando seus impactos, em diferentes escalas de tempo, tanto em relação ao meio ambiente, quanto em relação à saúde do consumidor. Não vejo o porquê da 'pressa' na liberação, a não ser para atender aos interesses das multinacionais.

(RESPONDENTE 14)

A transgenia é uma técnica que até agora só interessa aos detentores das patentes dessas sementes. $\mathrm{O}$ que esperamos é que o princípio da precaução seja usado [...]. Nota-se claramente uma irresponsabilidade para não dizer má fé nas liberações realizadas pela CTNBio.

(RESPONDENTE 16)

[...] devido a uma discussão não técnico-científica dos processos, aliada a uma disparidade entre os adeptos da biotecnologia e os críticos ao uso indiscriminado dessas técnicas [...], fazem com que o processo de discussão e votação para a liberação comercial de OGMs não seja transparente e nem legítimo $[\ldots]$.

(RESPONDENTE 17)

Os especialistas em Meio Ambiente também foram consonantes com as argumentações apresentadas pelos respondentes das categorias 02 e 03, no sentido de uma abertura à participação pública nos debates, que consideram ser direcionados ao atendimento 
dos interesses das grandes corporações. Uma articulação instituicional entre o órgão decisório e os de fiscalização deve ser promovida e o princípio da precaução necessita predominar nas tomadas de decisão, dadas as incertezas sobre os impactos ambientais de longo prazo decorrentes das liberações. Dentre algumas falas representativas, cabe-se citar:

[...] temos tido uma verdadeira avalanche pró-transgênicos impulsionada pelas empresas detentoras das patentes [...] a contaminação biológica causada pelas sementes transgênicas continua se espalhando pelas áreas de produção agrícola, sem que tenhamos nenhuma avaliação consubstanciada dos seus impactos [...].

(RESPONDENTE 18)

[...] é um tema típico da necessidade do Princípio da Precaução. Assim, sua discussão não deve se restringir à visão tecnocrática que despreza as incertezas do conhecimento científico e os valores culturais de uma sociedade [...]. Uma avaliação Ambiental Estratégica pode ser adotada para subsidiar a discussão pública.

(RESPONDENTE 22)

A política de biossegurança conduzida pela CTNBio [...] é fortemente afetada pela extraordinária capacidade das corporações transnacionais da biotecnologia que tem o oligopólio da tecnologia, não produzem informações suficientes [...] as discussões na CTNBio acabam sendo políticas e econômicas, esquecendo a biossegurança.

(RESPONDENTE 27)

[...] A complexidade do tema se expressa pela pluralidade de atores e questões envolvidas [...]. Daí a necessidade da implementação de instrumentos que contemplem a real dimensão do conflito subjacente ao tema dos transgênicos. Resta saber se a avaliação ambiental estratégica pode contribuir para esse processo.

(RESPONDENTE 28)

[...] tecnologias novas, cujas conseqüências sobre o ambiente e a saúde humana apresentam um elevado grau de incerteza, merecem análises de longo prazo antes de serem adotadas em larga escala [...] Sem um procedimento transparente, científico, de longo prazo e participativo a tomada de decisão [...] acaba sendo influenciada por interesses econômicos de determinados setores e é elevado o risco de externalização para a sociedade dos potenciais impactos negativos da decisão [...].

(RESPONDENTE 29)

Os participantes das ONGs que fizeram comentários concentraram-se também nas fragilidades do sistema regulatório brasileiro em garantir a biossegurança e os direitos dos consumidores e produtores quando das decisões sobre a liberação de OGMs. Levantaram a imprescindibilidade da participação pública por meio de uma maior representatividade da sociedade civil na CTNBio. Algumas falas são citadas a seguir: 
Apesar de constar em lei, a elaboração de uma política nacional de biossegurança está longe até mesmo de entrar na pauta de preocupação do governo [...]. Um peso desproporcional é atribuído à CTNBio, sendo que até hoje não houve análise de impacto social e econômico de nenhum organismo transgênico [...].

(RESPONDENTE 30)

Apesar de todos os protestos e manifestações da sociedade civil [...], as autoridades "competentes" do governo federal ignoram os seus argumentos e efetivam a defesa dos grandes produtores [...]. Os instrumentos de avaliação de risco, ou de impacto ambiental podem ser instrumentos capazes de apresentar soluções ou de prevenção, mas são "corrompidos" $[\ldots]$ a partir dos interesses da indústria $[\ldots]$.

(RESPONDENTE 35)

A insatisfação de muitos dos tópicos acima vem do modelo de Comissão técnica que temos e sua governança [...]. A composição com 12 cientistas e 5 representantes da sociedade fragiliza as posições daqueles que querem levar à Comissão um debate sobre o ponto de vista do consumidor, do produtor ou ambiental [...].

(RESPONDENTE 34)

O Código Penal Brasileiro precisa incorporar legislação a respeito dos OGMs que, dentre outras questões, preveja a proteção das sementes crioulas e de seus proprietários, assim como as empresas de biotecnologia têm garantido o direito pelo uso de suas tecnologias, tais como royalties e outras formas de controle. Além disso, é necessário cobrar dos órgãos oficiais o cumprimento integral da lei de ROTULAGEM.

(RESPONDENTE 37)

\section{$\checkmark$ Comentários sobre o questionário.}

As respostas do questionário evidenciaram o conflito de interesses e de entendimentos que estão presentes na discussão dos temas contemplados. Para a maioria dos respondentes, a liberação de PGMs no país é considerada uma questão estratégica, com o potencial de ocasionar impactos sociais, ambientais e econômicos positivos e negativos, interferindo sobre os objetivos ambientais e agrícolas pretendidos para o país. Há uma necessidade de levar em conta os potenciais impactos negativos cumulativos que se dão a partir de liberações sucessivas de PGMs em um horizonte temporal e espacial amplos; as alternativas de localização e de tecnologias, além da importância do monitoramento para garantir a biossegurança das PGMs e um maior controle social sobre as decisões. No entanto, apesar da importância destes aspectos, os participantes não consideram que os instrumentos existentes para identificar e avaliar os impactos ambientais e sócio-econômicos respondem por todas estas demandas, quais sejam a Análise de Risco e os Estudos de Impacto Ambientais, apesar da maior confiança no primeiro quanto à identificação dos impactos cumulativos e o 
monitoramento pós-comercial, os quais não são levados em conta na regulação destes organismos no Brasil. A maioria dos participantes também não conhece outros instrumentos adequados para tanto, com algumas sugestões apontando o Projeto GMO Era, que tem como instrumento de análise de impactos a Análise de Risco, e a Avaliação Ambiental Estratégica, que será abordada no capítulo sobre Políticas e instrumentos ambientais. Quanto à atuação dos órgãos regulatórios, a insatisfação é geral e em todos os parâmetros apontados, indicando uma necessidade de modificações no sistema regulatório de PGMs no Brasil, a fim de atendêlos, o que também pôde ser verificado nas considerações finais feitas por alguns participantes.

Em relação às categorias dos respondentes, verificou-se que os especialistas em biotecnologia e/ou biossegurança mostraram-se mais refratários à participação social nas tomadas de decisão, por se considerarem melhor conhecedores do assunto e reduzirem a questão dos transgênicos a um aspecto meramente técnico, sem implicações políticas e de valores sociais. Tal categoria também se mostrou mais satisfeita com o sistema regulatório de PGMs brasileiro e consideraram os parâmetros apontados (consideração dos impactos cumulativos, de outras PPPs, monitoramento e alternativas) mais irrelevantes em relação às demais categorias. Já estas, de modo geral, adotaram uma postura inversa à dos biotecnólogos, quanto aos parâmetros levantados, à adequação dos instrumentos existentes para considerá-los e sobre a regulação das PGMs no país. Uma maior discordância se deu na categoria representada pelas ONGs, provavelmente em função da diversidade de objetivos e ideologias que comportam tais organizações. Analisando-se o processo de deliberação sobre o algodão MON1445 e o questionário, percebe-se um conflito de visões sobre o tema dos transgênicos no país, que divide a comunidade científica e outros atores sociais. Tais conflitos se dão tem relação às normas, às atribuições das instituições envolvidas no processo regulatório, a transparência, representatividade dos diversos interesses, confiabilidade das análises de risco apresentadas pelos proponentes, instrumentos a serem utilizados nas avaliações de impactos ambientais e sócio-econômicos, dentre outros.

Dados estes resultados, conjuntamente a outras informações obtidas na literatura, realizar-se-á uma análise dos instrumentos de avaliação de impactos ambientais, sociais e econômicos, quais sejam, a Análise de Risco e o Estudo de Impacto Ambiental - atualmente utilizados ou previstos para subsidiar a deliberação sobre PGMs em escala comercial - assim como identificar as potencialidades de a Avaliação Ambiental Estratégica em contribuir para este processo, de modo a lidar com as controvérsias e incertezas identificadas, sob os princípios de uma boa governança ambiental que serão identificados na literatura. 


\section{POLÍTICA E INSTRUMENTOS AMBIENTAIS}

\subsection{Governança ambiental e OGMs}

O termo "governança ambiental", por conta de seu surgimento e uso recente, possui conceituação e princípios orientadores amplamente debatidos. Apesar da definição não estanque, relaciona-se, de modo geral, às formas como as sociedades lidam com seus problemas ambientais, por meio da constituição de redes de instituições formais e informais que regulam as informações, normas, processos e instrumentos de política e de financiamento relacionados ao meio ambiente (INSTITUTE FOR GLOBAL ENVIRONMENTAL STRATEGIES, 2001; NAJAM et al., 2006).

Basicamente, podem-se distinguir duas abordagens de governança: a participativa, em que a população interessada possui ou luta pelo acesso às tomadas de decisão, à justiça e às informações relacionadas ao meio ambiente, e a abordagem "de cima para baixo" (top-down), com o processo decisório sendo realizado de forma centralizada, por meio de autoridades governamentais competentes. Apesar de ser compreendida em relação a contextos políticoinstitucionais particulares, vem sendo concedida nas últimas décadas, uma maior abertura ao enfoque participativo de governança ambiental, como consequência das mudanças de valores sociais derivadas do debate ambiental em termos globais. Neste sentido, um maior entendimento sobre os benefícios sociais advindos do aumento da permeabilidade social nas decisões governamentais vem se consolidando como uma forma adequada para a escolha de estratégias ambientais amparadas nas realidades locais, por meio de seus próprios partícipes (IRWIN; HORST, 2005; NAJAM et al. 2006).

No tocante às políticas públicas, a governança ambiental participativa propicia o empoderamento dos diversos atores sociais diretamente afetados pelas tomadas de decisões que dizem respeito ao meio ambiente. Deste modo, o acesso à participação na proposição e desenvolvimento de políticas, às informações e à justiça ambiental são requisitos fundamentais para sua efetividade (PETKOVA et al., 2002).

Petkova et al. (2002) atribuem ao Princípio 10 da Declaração do Rio de Janeiro sobre o Meio Ambiente e o Desenvolvimento o conceito de governança ambiental, que se institui como premissa indispensável para o processo de desenvolvimento sustentável em suas dimensões social, econômica e ecológica: 
A melhor maneira de tratar de questões ambientais é assegurar a participação, no nível apropriado, de todos os cidadãos interessados. No nível nacional, cada indivíduo deve ter acesso adequado a informações relativas ao meio ambiente de que disponham as autoridades públicas, inclusive informações sobre materiais e atividades perigosas em suas comunidades, bem como a oportunidade de participar em processos de tomada de decisões. Os Estados devem facilitar e estimular a conscientização e a participação pública, colocando a informação à disposição de todos. Deve ser propiciado acesso efetivo a mecanismos judiciais e administrativos, inclusive no que diz respeito à compensação e reparação de danos.

(DECLARAÇÃO DO RIO DE JANEIRO SOBRE MEIO AMBIENTE E DESENVOLVIMENTO, 1992).

A importância da governança ambiental para o exercício da democracia participativa no trato das questões relativas ao meio ambiente se faz presente em todas as práticas que envolvam tomadas de decisão, por possibilitar uma melhor compreensão dos diversos aspectos da realidade, analisada pelos seus próprios partícipes. Deste modo, a gestão pode ser realizada de forma mais eficiente e justa ambiental, social e economicamente, já que múltiplos interesses passam a ser contemplados, permitindo a mediação dos conflitos existentes e o acompanhamento direto sobre a implementação das decisões realizadas. Segundo Walls et al. (2005 apud LEVIDOW, 2007) “[...] governança participativa acomoda a diversidade cultural, adequação social, e relações de poder mais equitativas; ela promove o processo eleitoral formal, em favor da sociedade civil.

É possível identificar, em função do debate e da prática internacionais a respeito de governança ambiental, alguns princípios gerais que configuram algumas de suas boas práticas, a saber (COMMONWEALTH OF AUSTRALIA, 2000; RIBOT, 2000; PETKOVA; PAPA; TAYAB, 2006; GOODWIN et al., apud COCKLIN; DIBDEN; GIBBS, 2008):

- Participação social na tomada de decisões, com identificação das demandas dos atores afetados pelas políticas públicas ou privadas a serem implementadas para o levantamento de alternativas e legitimidade em sua escolha de forma transparente;

- Inclusão de grupos sociais minoritários no processo de tomada de decisões, pois, frequentemente, não possuem acesso aos veículos de informação e decisão;

- Descentralização democrática nos processos decisórios, possibilitando a transferência de poder central a níveis mais baixos da hierarquia político-administrativa, garantindo a justiça, equidade e eficiência na gestão. Segundo Ribot (2002), ao tratar dos princípios para a gestão democrática dos recursos naturais, a qual se subentende como indispensável para a governança ambiental participativa, uma descentralização efetiva requer a representação com responsabilidade, ou seja, com legitimidade e prestação de contas, e a garantia do poder 
transferido (de preferência, legalmente), a fim de evitar seu condicionamento ao arbítrio dos órgãos centrais. Ainda segundo este autor, a transferência de poder deve ser plural, abrangendo todos os grupos de interesse da sociedade, para que assim se evite o favorecimento dos grupos mais poderosos e organizados;

- Responsabilidade compartilhada nas decisões tomadas, visando o aumento da conscientização dos atores envolvidos e o controle sobre sua implementação;

- Acesso à justiça, permitindo aos cidadãos a proteção dos seus direitos de acesso à participação e informação, bem como a contestação de decisões realizadas sem a consideração de seus interesses. Segundo Petkova et al (2002), um sistema nacional de acesso à justiça requer, dentre outros aspectos: garantias institucionais, mecanismos judiciais e administrativos imparciais na resolução e remediação de conflitos, consideração por parte do governo sobre os direitos dos cidadãos em matéria ambiental e informações sobre como acessá-los;

- $\quad$ Acesso à informação, permitindo a escolha de alternativas por parte dos cidadãos e a vigilância sobre o desempenho ambiental das indústrias e do governo, além de permitir a integração dos valores e anseios da população nos mecanismos decisórios. A necessidade da disseminação de informações concernentes ao meio ambiente, de participação nos processos de decisão e de acesso à justiça, está explicitada no princípio 10 da Declaração do Rio de Janeiro sobre Meio Ambiente e Desenvolvimento de 1992.;

- Coordenação entre as instituições e organizações que tratam de questões relevantes para o meio ambiente e desenvolvimento sustentável, permitindo a troca de informações e evitando sua duplicação, assim como a avaliação da efetividade das ações.

O caso da gestão dos Organismos Geneticamente Modificadas (OGMs) é propício ao exame das práticas de governança ambiental, por se tratar de atividades que lidam com bens de interesse coletivo da sociedade, como meio ambiente, saúde, bem-estar sócio-econômico e valores culturais. Além disto, sobrepesam-se as incertezas existentes sobre os impactos ambientais e à saúde humana e dos demais animais que possam resultar de práticas biotecnológicas, em virtude de seu uso recente, evidenciando o conteúdo eminentemente político das decisões tomadas (LEVIDOW, 2007). Problemas relacionados à distribuição dos riscos e benefícios da tecnologia são postos em pauta (COCKLIN; DIBDEN; GIBBS, 2008). O desafio da governança e regulação dos transgênicos por parte dos estados nacionais constitui-se, portanto, na criação de mecanismos socialmente acordados que possibilitem avaliar e sobrepesar os riscos e benefícios advindos da utilização de OGMs a todos os setores 
afetados, norteando-se pelas práticas de boa governança ambiental, tais como justiça ambiental, legitimidade, participação social nas tomadas de decisão, acesso às informações, prestação de contas, dentre outros (PETKOVA et al., 2002).

Como apresentado anteriormente, o Protocolo de Cartagena sobre Biossegurança, documento norteador na gestão de OGMs aos países signatários (dos quais o Brasil é signatário) apresenta como princípios gerais:

- a vigência do princípio da precaução nos processos decisórios sobre OGMs, dadas as incertezas científicas sobre os possíveis impactos ambientais, econômicos e sociais advindos de sua utilização.

- a análise de risco como ferramenta de avaliação de OGMs de modo caso-específico, ou seja, de acordo com as particularidades da modificação genética realizada e seu uso intencional, com as decisões baseadas no conhecimento científico mais recente.

Não obstante as características próprias de cada nação, tais princípios fazem-se presentes em praticamente todos os modelos regulatórios de OGMs ao redor do mundo. No processo de análise de risco, o critério de avaliação utilizado se baseia, geralmente, na comparação estrutural da variedade transgênica com sua contraparte convencional, o Princípio da Equivalência Substancial. Alguns países (Áustria e Itália), entretanto, utilizam variedades orgânicas como parâmetro comparativo ao OGM, visando o incentivo aos sistemas orgânicos de cultivo, considerados social e ambientalmente mais adequados (LEVIDOW; BOSCHERT, 2008).

De qualquer modo, a gestão de OGMs não pode ser considerada apenas em seu aspecto técnico, pois o processo de análise de risco envolve a identificação dos perigos, sua comunicação e gerenciamento, os quais dependem dos valores sociais e indicam o que e como os recursos naturais devem ser protegidos. Os riscos incertos impostos pela biotecnologia e os juízos de valor presentes em todas as etapas de avaliação da tecnologia quanto à definição do escopo de análise, formulação das hipóteses, termos de referência e critérios de análise, interpretação, ponderação dos resultados e tomada de decisão, requerem a abertura de canais entre governo, academia e sociedade, visando a legitimidade e transparência dos processos decisórios, a confiança pública nas instâncias de decisão, a prestação de contas e a aplicação prática dos princípios democráticos. A tais fatores somam-se os benefícios da contextualização das Políticas, Planos e Programas governamentais às reais demandas sociais, aos aspectos éticos e culturais dos locais de liberação e a consideração das diversas formas de conhecimento, para além daqueles estritamente especializados (NODARI; GUERRA; VALLE, 2002; LEVIDOW, 2007). 
No Brasil, a análise da governança ambiental envolvendo a liberação comercial de OGMs é considerada no presente trabalho pelo fato de tratar de interesses difusos e conflituosos, relacionados de forma interdependente ao meio ambiente, à saúde humana e ao bem-estar social. Deste modo, entende-se, de acordo com os princípios democráticos que regem o arcabouço legal do país, inclusive em se tratando da gestão ambiental, que a consideração desta questão seguindo as premissas de uma boa governança ambiental contribuiria para uma maior legitimidade de seus mecanismos decisórios. Segundo O'Connor e van den Hove (2001, p.80) "quando os riscos são elevados, valores divergem e as escalas temporais são longas, abordagens puramente "técnicas" para a avaliação de riscos e governança não são robustas". Neste sentido, um processo participativo que envolva todos os interessados na ação durante as fases de julgamento, decisão e gestão possibilitam resultados mais justos.

Tendo em vista os princípios para uma boa governança ambiental identificados, será feita a avaliação dos instrumentos utilizados para os estudos ambientais delimitados no item 5.5., levando-se em conta estas premissas (Análise de Risco, Estudo de Impactos Ambientais e Avaliação Ambiental Estratégica), iniciando pela revisão conceitual e procedimental dos instrumentos. A Análise de Risco será revisada à parte dos demais instrumentos pelo fato de não ser contemplada como um instrumento de Avaliação de Impactos Ambientais como disposto na Lei 6938/81.

\subsection{Análise de Risco: conceituação}

A Análise de risco é uma ferramenta de avaliação para a tomada de decisões quando existe a possibilidade de danos de qualquer natureza, sendo a combinação de dois componentes: probabilidade de ocorrer um evento que provoque dano e o dano provocado propriamente dito (KIRCHHOFF, 2004). De acordo com a National Academy of Sciences (2002 apud KIRCHHOFF, 2004), o risco pode ser definido como um perigo potencial de ocasionar danos, injúrias ou outras consequências indesejadas à saúde, ao bem-estar ou ao meio ambiente.

Em análise de risco, diferencia-se perigo de risco, sendo "perigo [...] definido como uma situação ou condição que tem potencial de acarretar consequências indesejáveis" (SÁNCHEZ, 2006, p. 318), como uma característica intrínsica de uma substância, instalação ou artefato. Já o risco é definido como uma "contextualização de uma situação de perigo, ou seja, a possibilidade da materialização do perigo ou de um evento indesejável ocorrer" 
(SÁNCHEZ, 2006, p.319). De acordo com a Society for Risk Analysis (sem data apud SÁNCHEZ, 2006, p. 320), risco é “o potencial de realização de consequências adversas indesejadas para a saúde ou vida humana, para o ambiente ou para bens materiais", sendo a probabilidade de ocorrência do evento pela magnitude das consequências (danos), representada pela fórmula:

$\mathrm{R}=\mathrm{P} . \mathrm{D}$

Sendo que:

$$
\begin{aligned}
& \mathrm{R}=\text { Risco } \\
& \mathrm{P}=\text { Probabilidade de ocorrer um evento } \\
& \mathrm{D}=\text { Dano }- \text { a partir do evento ocorrido }
\end{aligned}
$$

Deste modo, o grau de risco depende da relação entre estas duas variáveis (probabilidade e danos) e será de grande montante nos casos em que a probabilidade for pequena, mas os impactos forem elevados ou em situações de elevadas probabilidade e significância de impactos. Nas situações em que a probabilidade for elevada, mas as consequências forem menos severas, o julgamento sobre o risco poderá variar. De qualquer forma, os riscos sempre dependem da localização e de seus potenciais danos (SÁNCHEZ, 2006).

Um risco (hazard, em inglês) pode ser exemplificado de forma bem simples: ao dizer que uma estrada é perigosa não significa que algum acidente de carro tenha ocorrido, mas sim que as condições da estrada potencialmente podem proporcionar acidentes, o que pode ou não vir a acontecer. No tocante aos riscos ambientais, na definição da US Environmental Protection Agency (2008), é a chance de efeitos prejudiciais à saúde humana ou aos sistemas ecológicos resultantes da exposição a um agente estressante se sucederem, consistindo este uma entidade física, química ou biológica que induz a uma adversidade aos recursos naturais e ecossistemas. Quanto à sua origem, Sánchez (2006) aponta que os riscos derivam do mau funcionamento de processos tecnológicos e outras ações antrópicas.

As análises de risco possuem em seu histórico as preocupações com danos à saúde pública e ao meio ambiente ocasionados por substâncias químicas perigosas, tais como organoclorados e dioxinas, acidentes nucleares, industriais e com produtos alimentícios. Inicialmente, as preocupações com a segurança pública se deram nos EUA, na década de 1920, especificamente com a indústria alimentícia e, desde a década de 1930, trabalhos em toxicologia passaram a ser desenvolvidos no sentido de avaliar os possíveis danos 
ocasionados por substâncias perigosas (COMPANHIA AMBIENTAL DO ESTADO DE SÃO PAULO, 2001).

Um marco nos estudos de análise de risco se deu em 1974, por conta de um acidente industrial em Flixborough, na Inglaterra, levando à criação do Advisory Committee on Major Hazards, introduzindo uma legislação de controle de riscos industriais no país. Em 1976, outro acidente químico, com liberação de dioxina em um reator em Seveso, Itália, conduziu à criação da Diretiva de Seveso, convertida em uma Diretiva Européia de 1982, que visava um maior controle de acidentes indústriais. Outros acidentes de repercussão mundial, tais como o de Chernobyl em 1986 na Ucrânia, levaram ao desenvolvimento de legislações e regulamentos sobre análise e prevenção de riscos tecnológicos por todo o mundo (COMPANHIA AMBIENTAL DO ESTADO DE SÃO PAULO, 2001; SÁNCHEZ, 2006).

Há dois tipos de riscos: o crônico, quando o meio receptor é exposto continuamente ao impacto, sem letalidade imediata, tal como a exposição permanente de uma dada população à emissão de poluentes atmosféricos; e o agudo, com a exposição se dando em doses altas e letais aos seres vivos (SÁNCHEZ, 2006). A identificação do risco depende de sua tipologia, ou seja, de origem natural ou de processos tecnológicos. Nos riscos tecnológicos, nos quais os OGMs se enquadram, segundo Sánchez (2006), riscos agudos são mais fáceis de serem identificados, pelo fato da determinação das situações de causa e efeito, o que é mais problemático no caso de riscos crônicos. Além disto, os efeitos são imediatos nos riscos agudos, ao contrário dos crônicos, que ocorrem em médio e longo prazos.

As análises de risco envolvem, geralmente, três etapas (CARPENTER, 1995; KATES, 1978 apud SÁNCHEZ, 2006; HENRY, 2006; KIRCHHOFF, 2004):

- identificação dos riscos;

- análise das consequências e estimativas dos riscos;

- gerenciamento dos riscos.

A identificação dos riscos consiste na análise do que, quando, onde e como algo pode se suceder de forma errônea e os eventos que podem conduzir aos efeitos adversos. Considera-se tal etapa como fundamental para a análise de risco, já que qualquer falha em sua detecção pode comprometer o processo, subestimando os prováveis danos. As ferramentas metodológicas utilizadas nesta fase são, em sua maioria, dedutivas, dependendo do objeto em análise, e consistem em (HENRY, 2006; KIRCHHOFF, 2004; STIRLING, 2009):

- comparação com experiências prévias;

- listagem de controle (cheklists), geralmente com consulta a especialistas (brainstorming); 
- cenarização (técnica What if);

- FMA (Failure Mode and Effects Analyisis), que consiste em estudos de falhas em componentes que possam afetar a segurança da operação;

- HazOp (Hazard and Operability Study), método que investiga potenciais problemas de operação que possam causar desvios nos parâmetros em relação às condições do projeto;

- Árvore de Evento, que consiste em uma análise quantitativa das consequências dos eventos iniciantes, por meio de um diagrama;

- Árvore de falhas: adota o mesmo procedimento da Árvore de Evento, mas na direção contrária, por meio de um diagrama que apresenta as causas das consequências identificadas, buscando-se analisar os potenciais pontos críticos que causem falhas no sistema analisado;

Além destas, outras metodologias também são abordadas por Stirling (1999):

- Conferências de consenso;

- Células de planejamento;

- Júris de cidadãos (citizen’s júris);

- Grupos focais;

- Sondagens deliberativas (deliberative pools).

De acordo com Kolluru apud Kirchhoff (2004, p.13), os analistas de risco devem:

- Definir os limites analíticos;

- Identificar os riscos geralmente associados ao empreendimento, e sua operação;

- Determinar inventários de materiais perigosos, localização, transporte e manuseio;

- Identificar eventos iniciantes;

- Revisar procedimentos de segurança de engenharia e administrativos;

- Identificar potencial de vazamentos catastróficos repentinos baseado em cenários de falha creditáveis.

Para além das metodologias existentes na identificação dos riscos, o National Research Council (1996) estabelece a importância de se considerar os anseios das diversas partes afetadas e as premissas que conduzem à etapa de estimativa de riscos, levando em conta as consequências ambientais, sociais e econômicas, sobretudo às populações mais fragilizadas. Tal processo depende de um público diversificado que represente todos os interessados, os tomadores de decisão e especialistas na análise de risco em todas as suas etapas

A identificação do risco é seguida pela análise da probabilidade do efeito adverso ocorrer e sua severidade, considerando sua extensão temporal e espacial, reversibilidade e, de 
preferência, seus impactos cumulativos. A estimativa do risco é a combinação entre a probabilidade e as consequências do dano potencial, incorporando as incertezas de o fato se suceder. Neste momento, devem-se considerar as incertezas inerentes à falta de conhecimento (como ausência de informações) e à imprevisibilidade e variabilidade do sistema em análise (US ENVIRONMENTAL PROTECTION AGENCY, 2008).

A estimativa do risco é fundamental para a tomada de decisões, a partir das quais se tem as opções de não assumir os riscos, manejá-los e/ou mitigá-los. No caso de riscos ecológicos, não há uma metodologia universalmente aceita para tanto, apesar de algumas técnicas estarem à disposição (HAYES, 2003 apud HENRY, 2006), dada a complexidade das relações ecológicas, a relativa falta de experiência na avaliação de riscos ecológicos como uma disciplina do conhecimento, a variedade de agentes estressores e a identificação de suas consequências sobre o objeto de avaliação (HENRY, 2006).

Os estudos de risco podem ser integrados aos estudos de impactos ambientais ou realizados separadamente, como ocorre no estado de São Paulo, em que cabe à CETESB a solicitação e avaliação de AR e ao Departamento de Avaliação de Impacto Ambiental da Secretaria do Meio Ambiente os EIAs (SÁNCHEZ, 2006).

$\mathrm{O}$ gerenciamento dos riscos define-se como um conjunto de medidas e procedimentos técnicos e administrativos que se objetiva a prevenir, reduzir e/ou mitigar os riscos. A redução dos riscos pode se dar por meio de medidas que diminuam tanto as frequências dos acidentes (com ações preventivas) quanto suas consequências (com ações de proteção e/ou mitigação) (COMPANHIA AMBIENTAL DO ESTADO DE SÃO PAULO, 2001). No caso de ocorrência de acidentes, medidas emergenciais devem ser adotadas para a mitigação dos danos (SÁNCHEZ, 2006). A US Environmental Protection Agency, órgão de proteção ambiental dos EUA, que elabora regulamentações e fiscaliza as atividades potencialmente lesivas ao meio ambiente, exemplifica as seguintes ações para a gestão de riscos: a definição legal do volume de efluentes que uma companhia pode lançar em um rio, o estabelecimento de padrões de qualidade da água, do ar e do solo, dentre outras (US ENVIRONMENTAL PROTECTION AGENCY, 2008).

De qualquer modo, a prevenção dos acidentes depende da localização do empreendimento (SÁNCHEZ, 2006).

A deliberação acerca dos riscos a serem evitados, mitigados ou minimizados depende da eficácia de cada etapa da análise, desde a identificação dos danos potenciais por todos os interessados, transparecendo no final as incertezas quanto sua durabilidade, tendo de antemão a consciência de que nem todas as controvérsias podem ser resolvidas. As limitações 
metodológicas da análise, em parte dadas pela falta de informações, imprevisibilidade dos sistemas e/ou ignorância acerca dos eventos e potenciais danos devem ser identificadas e explanadas às partes (NATIONAL RESEARCH COUNCIL, 1996).

De acordo com o National Research Council (1996), atenção redobrada deve ser dada às técnicas de análise quantitativa ou qualitativa de custo-benefício, pois muitas vezes os valores sociais atribuídos aos riscos podem ser desconsiderados, além de simplificar as situações reais. Do mesmo modo, tais análises devem necessariamente considerar as incertezas já mencionadas anteriormente, devendo os participantes abordar tanto suas características, ou seja, se ocorrem devido à aleatoriedade dos eventos ou pela falta de conhecimento. A deliberação sobre a aceitação, negação e o gerenciamento dos riscos deve se ater à confiabilidade científica das metodologias utilizadas e às incertezas identificadas, considerando-se os eventos surpresa. Torna-se importante, para tanto, que a identificação e interpretação das incertezas incluam o contexto social, cultural e institucional do sistema em análise.

A fim de tornar transparente e socialmente confiável, as decisões sobre os riscos devem atender aos seguintes requisitos, segundo o National Research Council (1996):

- utilizar metodologias cientificamente embasadas em termos de dados, análises, plausibilidade das premissas adotadas, respeito à magnitude e características das incertezas e suas limitações;

- a análise deve refletir as preocupações das instituições oficiais e das partes afetadas, incluindo avaliações sobre os riscos à saúde, meio ambiente, bem-estar, economia e valores sociais, com enfoque às questões mais proeminentes;

- garantir ampla participação em todas as etapas, possibilitando que todas as informações e perspectivas sejam consideradas, de modo legítimo e transparente;

- o processo deve satisfazer a todos os interessados, com seus pontos de vista, preocupações, informações e conhecimentos sendo devidamente considerados;

- a análise de risco deve apresentar o estado atual do conhecimento, as incertezas e limitações existentes, assim como os conflitos identificados.

No Brasil, a Lei 11.105 estabeleceu a avaliação de risco como instrumento ambiental que norteia a tomada de decisões sobre a liberação planejada ou comercial de OGMs, a qual é elaborada pela empresa ou instituição proponente e analisada pela CTNBio, o órgão competente pelas deliberações.

A definição de critérios legais para a solicitação à CTNBio sobre a comercialização de OGMs está contida na Resolução Normativa No.05, de 12 de março de 2008. Dentre as 
informações requeridas ao empreendedor encontram-se a análise de risco à saúde humana, animal e ao meio ambiente e a apresentação de um plano de monitoramento pós-comercial. Com relação ao OGM, se deve informar (COMISSÃO TÉCNICA NACIONAL DE BIOSSEGURANÇA, 2008a):

- O tipo de transformação genética realizada;

- As características dos organismos vetor e receptor;

- O mapa genético utilizado;

- O grau de estabilidade genotípica;

- Os produtos da expressão gênica, incluindo os efeitos pleiotrópicos observados;

- Modificações capazes de conferir vantagens reprodutivas e de sobrevivência ao OGM.

A avaliação dos riscos à saúde humana e dos outros animais necessita conter (COMISSÃO TÉCNICA NACIONAL DE BIOSSEGURANÇA, 2008a):

1. o histórico de uso na alimentação, no Brasil e em outros países do organismo parental ou doador, indicando o nível de consumo, o processamento anterior ao consumo e as espécies animais que se alimentam destes organismos;

2. possíveis efeitos na cadeia alimentar humana e animal pela ingestão de OGM e seus derivados;

3. as diferenças de composição química e nutricional entre o alimento oriundo do vegetal geneticamente modificado e do vegetal não modificado, in natura ou após processamento e a existência de equivalência substancial entre o OGM e seu organismo parental;

4. as alterações relativas ao desempenho do animal, quando alimentado com organismos geneticamente modificados ou qualquer de suas partes, in natura ou após processamento, fornecendo, inclusive, os resultados da avaliação da nutrição em animais experimentais por duas gerações, indicando as espécies utilizadas nos testes, duração dos experimentos, variações fisiológicas e morfológicas observadas em relação aos grupos-controle e alteração da qualidade nutricional, se houver;

5. a estabilidade à digestão e ao processamento industrial da proteína especificada pelo transgene com base nas propriedades físico-químicas;

6. os possíveis efeitos deletérios do OGM em animais prenhes e seu potencial teratogênico;

7. as conclusões de análises imunológicas e histológicas de tecidos relevantes, especialmente do trato digestivo;

8. a capacidade do OGM de produzir toxinas ou metabólitos que causem efeitos adversos ao consumidor, animal ou humano, relatando as evidências experimentais;

9. as avaliações toxicológicas e farmacológicas realizadas em animais experimentais, descrevendo os resultados;

10. a similaridade dos produtos de expressão do OGM com alérgenos conhecidos, relatando possíveis reações alérgicas identificadas após ingestão do OGM nas avaliações em animais experimentais, descrevendo os resultados. 
Em relação aos riscos ambientais, estabelecem-se critérios específicos para cada uma das seguintes categorias de OGMs: plantas; microorganismos; microorganismos que vivem associados a animais; microorganismos associados a plantas; organismos utilizados como controle biológico; organismos para biorremediação; animais vertebrados (excluindo peixes); peixes e demais organismos de vida aquática e animais invertebrados. Pelo fato de o presente trabalho dedicar-se às plantas geneticamente modificadas, apresentam-se apenas as informações que devam constar em suas análises de risco, quais sejam (COMISSÃO TÉCNICA NACIONAL DE BIOSSEGURANÇA, 2008a, anexo A):

1. a área de ocorrência natural do organismo parental do OGM, seus ancestrais e parentes silvestres - centros de origem e de diversidade genética - e espécies ancestrais ou parentes silvestres, existentes em algum ecossistema brasileiro do mesmo gênero da espécie parental não-modificada;

2. a história de cultivo e de uso do organismo parental em termos de segurança para o meio ambiente, para o consumo humano e animal, informando sobre a possibilidade de hibridação introgressiva com as espécies sexualmente compatíveis e sobre a possível vantagem seletiva do transgene;

3. os possíveis efeitos em organismos indicadores relevantes (simbiontes, predadores, polinizadores, parasitas ou competidores do OGM) nos ecossistemas onde se pretende efetuar o seu cultivo, em comparação com o organismo parental do OGM em um sistema de produção convencional;

4. a capacidade de dispersão das estruturas de propagação e reprodução do OGM além das áreas de cultivo e os mecanismos de sua dispersão no ar, na água e no solo, fornecendo informações sobre a viabilidade do pólen da planta e indicando os agentes polinizadores potenciais e sua distribuição geográfica no Brasil;

5. a possibilidade de formação de estruturas de reprodução de longo prazo no organismo parental;

6. a frequência com que ocorre o cruzamento do organismo parental do OGM, dentro da mesma espécie e com espécies sexualmente compatíveis, arrolando as espécies avaliadas, as técnicas utilizadas e os efeitos resultantes;

7. os efeitos resultantes da transferência horizontal para a microbiota do solo, caso ocorra;

8. os impactos negativos e positivos aos organismos alvo e não-alvo que poderão ocorrer com a liberação do OGM, arrolando as espécies avaliadas, as razões da escolha e as técnicas utilizadas para demonstrar os impactos;

9. as modificações da capacidade da planta em adicionar ou remover substâncias do solo, em decorrência da introdução de novas características, descrevendo possíveis alterações físicas e químicas no solo e contaminação dos corpos d'água adjacentes resultantes das interações com o OGM, comparativamente aos sistemas convencionais; 
10.as possíveis modificações da biodegradabilidade da planta GM, comparativamente ao genótipo parental;

11. a possível resistência a agentes químicos conferida pela característica introduzida;

12. o histórico de uso do OGM e os países onde já foram autorizadas ou recusadas a sua comercialização e plantio apresentando, neste caso, dados de monitoramento ou de estudos pós-liberação comercial, se houver;

13. as alterações na capacidade de sobrevivência do OGM em ambientes distintos daqueles ocupados pelo parental, provocadas pelas novas características introduzidas.

Em termos de classificação dos riscos, a CTNBio promulgou a Resolução Normativa No.02 de 27 de novembro de 2006, visando a determinação de níveis de biossegurança para pesquisas, manipulação, ensino, armazenamento, controle de qualidade e descarte envolvendo OGMs em contenção, ou seja, “[...] atividades e projetos com OGMs em condições que não permitam o seu escape ou liberação para o meio ambiente, podendo ser realizado em pequena ou grande escala". (COMISSÃO TÉCNICA NACIONAL DE BIOSSEGURANÇA, 2006). Não é objeto da Resolução a liberação de OGMs no meio ambiente, mas é possível subentender que os estudos que desencadeiem a classificação de um OGM nos processos de pesquisa definem sua classe mesmo quando de sua liberação sem contenção.

Os OGMs podem ser classificados em quatro classes de risco, tendo como critérios o potencial patogênico dos organismos doador e receptor, as sequências nucleotídicas transferidas e sua expressão no organismo receptor, além do OGM resultante e seus efeitos à saúde humana e animal, aos vegetais e ao meio ambiente. As classes de risco são as seguintes (COMISSÃO TÉCNICA NACIONAL DE BIOSSEGURANÇA, 2006, art. 8):

I - Classe de Risco 1 (baixo risco individual e baixo risco para a coletividade): O OGM que contém sequências de ADN/ARN de organismo doador e receptor que não causem agravos à saúde humana e animal e efeitos adversos aos vegetais e ao meio ambiente;

II - Classe de Risco 2 (moderado risco individual e baixo risco para a coletividade): O OGM que contém sequências de ADN/ARN de organismo doador ou receptor com moderado risco de agravo à saúde humana e animal, que tenha baixo risco de disseminação e de causar efeitos adversos aos vegetais e ao meio ambiente;

III - Classe de Risco 3 (alto risco individual e risco moderado para a coletividade): O OGM que contém seqüências de ADN/ARN de organismo doador ou receptor, com alto risco de agravo à saúde humana e animal, que tenha baixo ou moderado risco de disseminação e de causar efeitos adversos aos vegetais e ao meio ambiente; 
IV - Classe de Risco 4 (alto risco individual e alto risco para a coletividade): O OGM que contém sequências de ADN/ARN de organismo doador ou receptor com alto risco de agravo à saúde humana e animal, que tenha elevado risco de disseminação e de causar efeitos adversos aos vegetais e ao meio ambiente.

Outros aspectos a considerar incluem:

- Potencial de recombinação das sequências inseridas no OGM, conduzindo à reconstituição completa dos genes de agentes infecciosos;

- $\quad$ Outros processos que levem à formação de agentes infecciosos;

- Genes que codifiquem material tóxico ao ser humano, demais animais, vegetais ou ao meio ambiente e genes de resistência a antibióticos de uso amplo.

Como pertencentes à classe 2 ou superior encontram-se os OGMs que sejam plantas invasoras ou espontâneas, que possam cruzar com estas produzindo descendentes férteis com maior capacidade de invasão e dano ao meio ambiente do que os organismos parentais ou que sejam vetores biológicos de agentes nocivos ao ser humano e ao meio ambiente. A classe de risco pode ser aumentada quando o OGM apresentar capacidade de sobrevivência maior do que suas contrapartes convencionais (COMISSÃO TÉCNICA NACIONAL DE BIOSSEGURANÇA, 2006, art. 8, parág. 4 a 7). No entanto, não há a definição dos limites para o enquadramento do OGM em uma determinada classe de risco, nem mesmo critérios e procedimentos de análise para tanto. Os níveis de biossegurança correspondem às classes de risco dos OGMs envolvidos, sendo que, no caso da utilização de diversos OGMs, o organismo que apresentar o maior risco determina o nível de biossegurança. Há quatro níveis de biossegurança, cada qual com especificações no tocante à instalação do projeto e procedimentos a serem adotados (COMISSÃO TÉCNICA NACIONAL DE BIOSSEGURANÇA, 2006, cap. V):

I- Nível de Biossegurança 1 (NB-1): adequado às atividades e projetos que envolvam OGM da classe de risco 1 [...]

I - Nível de Biossegurança 2 (NB-2): adequado às atividades e projetos que envolvam OGM de classe de risco 2 [...].

III - Nível de Biossegurança 3 (NB-3): adequado às atividades e projetos que envolvam OGM de classe de risco 3 [...].

IV - Nível de Biossegurança 4 (NB-4): adequado às atividades e projetos que envolvam OGM de classe de risco 4 [..]

\subsection{Avaliação de Impactos Ambientais: origem e tipologias}


As avaliações de impactos ambientais (AIA) surgiram por uma necessidade de harmonizar o desenvolvimento econômico e a proteção ambiental, no sentido de um desenvolvimento sustentável do ponto de vista ambiental, econômico e social, tal como reafirmado na Conferência de Estocolmo sobre Meio Ambiente e Desenvolvimento Humano de 1972. Existem diversas definições para o termo, tais como de Munn (1979 apud GLASSON; THERIVEL; CHADWICK, 2001) à adotada no Reino Unido (DOE, 1989 apud GLASSON; THERIVEL; CHADWICK, 2001):

[...]a identificação e predição de impacto sobre o meio ambiente e sobre a saúde humana e seu bem-estar, provenientes de propostas legislativas, políticas, programas, projetos e procedimentos operacionais, e a interpretação e comunicação da informação sobre os impactos.

(MUNN, 1979 apud GLASSON; THERIVEL; CHADWICK, 2001)

O termo 'avaliação ambiental' descreve uma técnica e um processo pelos quais informações sobre os efeitos ambientais de um projeto são coletadas, tanto pelo proponente e obtida de outras fontes, e levadas em conta pela autoridade planejadora na formação de seus julgamentos a respeito se o desenvolvimento deve ir em frente.

(DOE, 1989 apud GLASSON; THERIVEL; CHADWICK, 2001)

Segundo Sánchez (2006), o termo possui diversas interpretações, mas que, no geral, visa a descrição dos impactos ambientais provenientes de atividades humanas " [...] incluindo tanto os impactos causados pelos processos produtivos quanto aqueles decorrentes dos produtos dessa atividade" (SÁNCHEZ, 2006, p.05). O objetivo da avaliação de impactos ambientais é identificar e julgar a importância dos impactos antes da tomada de decisões, evitando ou minimizando uma potencial e significativa degradação ambiental.

No início de sua concepção, a AIA tinha por objetivo avaliar os impactos de projetos ou atividades de desenvolvimento ligados a obras de engenharia, mas ampliou-se para a avaliação de Políticas, Planos e Programas (PPPs) que antecedem estes projetos. No Brasil e em outras nações, as AIAs abragem a avaliação dos impactos ambientais de projetos, a qual dá-se o nome de Estudo de Impacto Ambiental (EIA) e a avaliação de PPPs, que se denomina Avaliação Ambiental Estratégica (AAE), ainda não regulamentada no país. Esta tem sua origem na década de 80 e apresenta várias vertentes, de acordo com as especificidades das nações em que se encontram consolidadas (SÁNCHEZ, 2006).

A AIA pode ser entendida como um processo e não simplesmente um produto finalizado, sistematizada em procedimentos definidos em legislação e enfatizando a 
prevenção dos impactos ambientais negativos potenciais. Para tanto, é realizada de forma multidisciplinar e holística. Os impactos ambientais podem ser benéficos, negativos ou neutros e possuem características tais como magnitude, reversibilidade e duração, que são atribuídas de acordo com valores sociais e são a base para o julgamento da atividade ou PPPs. Antes de se deter sobre os procedimentos da AIA e suas diferenciações em EIA e AAE, cabe explicitar algumas definições de meio ambiente, impacto ambiental e seus subtipos, seguidos pelo histórico da AIA.

Segundo Grinover (1989 apud TOMMASI, 1994), meio ambiente pode ser considerado como as interações entre os fatores abióticos, tais como o solo, ar e água e os fatores bióticos, como fauna e flora, incluindo as práticas sociais humanas. Para Sachs (1986 apud TOMMASI, 1994, p.11), o meio ambiente "inclui o natural, as tecnoestruturas criadas pelo homem (ambiente artificial) e o ambiente social (ou cultural). [...] Assim, meio ambiente inclui os domínios ecológico, social, econômico e político".

De acordo com Sánchez (2006), na área de planejamento e gestão ambiental, a conceituação de meio ambiente possui múltiplos aspectos, pois inclui tanto o natural como a sociedade humana e é maleável, porque pode ser delimitado de acordo com as necessidades e interesses dos envolvidos e do analista. A separação geralmente feita entre natureza e Homem, que suscita diversas discussões de cunho filosófico, muitas vezes pode conduzir a uma avaliação de impactos ambientais que considere apenas os elementos ditos "naturais", tais como a fauna, flora e os fatores abióticos, desconsiderando os impactos sociais e econômicos, principalmente dos agrupamentos humanos mais desfavorecidos. Por outro lado, pode conduzir a uma visão estritamente utilitarista dos aspectos "naturais" pelo ser humano, imbuída no conceito de recursos naturais, como se os aspectos ambientais servissem apenas para satisfazer as necessidades humanas.

Já em relação aos impactos ambientais, assim como para o conceito de meio ambiente, têm-se diversas definições. No Brasil, o conceito de impacto ambiental está presente na Resolução CONAMA No. 01/86, art. $1^{\circ}$ (CONAMA, 1986), da seguinte forma:

Qualquer alteração das propriedades físicas, químicas ou biológicas do meio ambiente, causada por qualquer forma de matéria ou energia resultante das atividades humanas, que direta ou indiretamente afetem:

I - a saúde, a segurança e o bem-estar da população;

II - as atividades sociais e econômicas;

III - as condições estéticas e sanitárias do meio ambiente;

IV - a qualidade dos recursos ambientais. 
Deste modo, no Brasil, o termo se configura estritamente aos efeitos provocados pela ação humana sobre o ambiente, seja este natural ou humano, excluindo os efeitos ocasionados por causas naturais, tais como furacões, terremotos, maremotos, incêndios florestais de origem não antrópica, dentre outros. Tais impactos provocados pelas atividades humanas podem se subdividir em benéficos ou adversos, diretos, indiretos, de curta, média ou longa duração, cumulativos, reversíveis ou irreversíveis, os quais podem ser assim definidos (SÁNCHEZ, 2006; EUROPEAN COMMUNITIES, 1999):

$\checkmark$ Benéficos ou adversos: benéficos quando ocasionam ações positivas sobre o sistema e adversos quando de seu oposto. No entanto, como os sistemas ambientais são intrinsecamente complexos, um impacto pode se apresentar positivo para um determinado fator ambiental e revelar-se adverso para outro;

$\checkmark$ Impactos diretos: apresentam-se durante a atividade em questão;

$\checkmark$ Impactos indiretos: que não resultam diretamente de um projeto e sendo geralmente produzidos como resultado de uma cadeia de eventos complexos. São geralmente definidos como impactos de segundo ou terceiro níveis, ou impactos secundários. Esquematicamente, podem ser representados da seguinte forma:

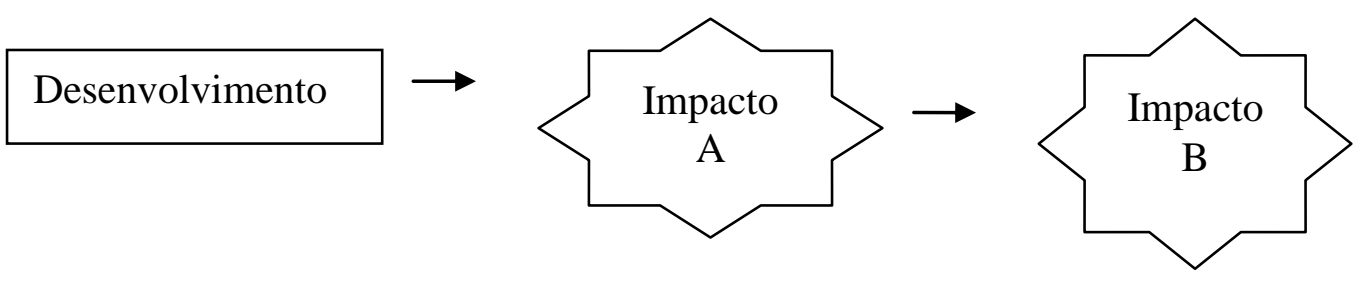

Figura 03: Representação de impacto indireto.

Fonte: Adaptado de European Communities (1999, p.iii).

$\checkmark$ Impactos cumulativos: “[...] resultam de mudanças incrementais causadas por outras passadas, presentes ou futuras ações que se somem ao projeto" (EUROPEAN COMMUNITIES 1996, p. iii). Segundo Sánchez (2006, p. 462), são “impactos que se acumulam no tempo ou no espaço, e resultam de uma combinação de efeitos decorrentes de uma ou diversas ações”. Podem ser representados pelos seguintes esquemas, sendo o primeiro referente a um mesmo tipo de impacto e o segundo à interação entre impactos distintos: 


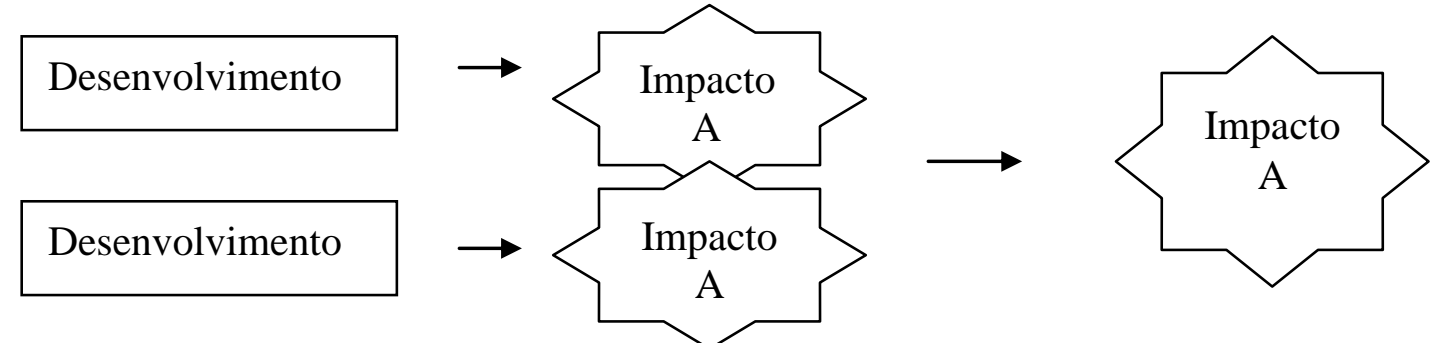

Figura 04: Representação de impacto cumulativo resultante da combinação de um mesmo tipo de impacto.

Fonte: Adaptado de European Communities (1994).

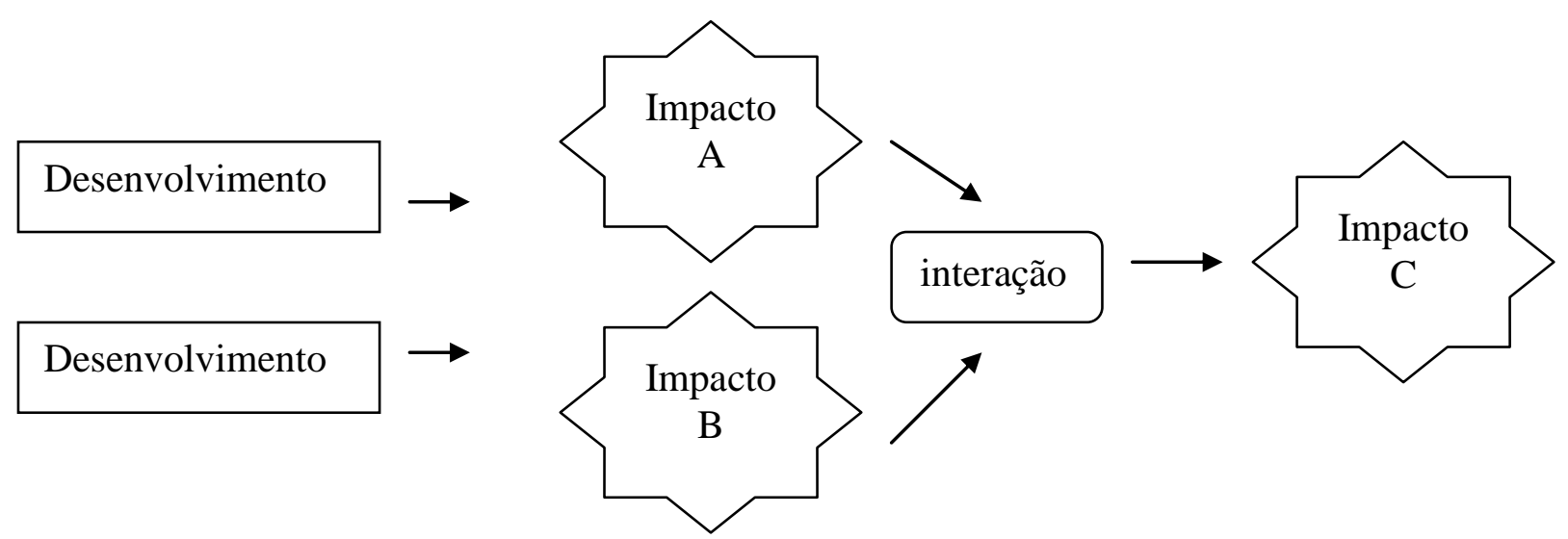

Figura 05: Representação de impacto cumulativo resultante da interação entre impactos diferentes. Fonte: Adaptado de European Communities (1994).

$\checkmark \quad$ Impactos de curto prazo: são aqueles que ocorrem simultaneamente à ação que os ocasiona;

$\checkmark \quad$ Impactos de médio e longo prazo: ocorrem após passado um médio ou longo período à ação que os ocasionou;

$\checkmark \quad$ Impactos reversíveis ou irreversíveis: depende da capacidade do sistema em retornar à condição anterior ao impacto (reversível) ou não (irreversível).

Sánchez (2006) aponta algumas diferenciações entre impacto ambiental e poluição, conceitos que se assemelham e ocasionam confusões de interpretação. Segundo o autor, o conceito de impacto ambiental é mais amplo, pois, enquanto que poluição possui uma conotação totalmente negativa, o impacto ambiental pode ser tanto negativo quanto benéfico. A poluição se refere à matéria ou energia, que podem ser medidas e terem padrões definidos, tais como os padrões de emissão de poluentes atmosféricos e de efluentes, enquanto que diversas ações humanas podem ocasionar impactos significativos sem estarem associados à emissão de poluentes, tais como as barragens para a construção de hidreelétricas. Além disto, toda poluição ocasiona impactos ambientais, já que são materiais ou energias que são 
lançados no meio acima de sua capacidade assimilativa, mas nem todo impacto ambiental tem como causa alguma fonte poluidora. Neste sentido, Sánchez não considera a definição de impacto ambiental dada pela Resolução CONAMA No.01/86 adequada, por assemelhar-se mais ao conceito de poluição, já que menciona apenas a emissão de matéria e energia.

Para Sánchez, qualquer atividade humana pode ocasionar alterações ambientais e sócio-econômicas benéficas ou adversas, o que precisa ser considerado em qualquer estudo de impacto ambiental. Para tanto, os valores dos atores sociais afetados e interessados pela ação, assim como a legislação devem ser levados em conta.

\section{$\checkmark$ Origem da AIA}

A avaliação de impactos ambientais é um instrumento de política ambiental amplamente difundido pelo mundo, tanto em países quanto em organizações internacionais, sendo reconhecida inclusive em tratados internacionais, como fundamental para a implementação do conceito de desenvolvimento sustentável (SÁNCHEZ, 2006).

A avaliação de impactos ambientais foi inicialmente formalizada em legislação em 1969 nos Estados Unidos da América, por meio do National Environmental Policy Act (NEPA), um modelo de política ambiental que inspirou diversos países a adotarem mecanismos semelhantes para a consideração das consequências ambientais provenientes das ações humanas, sejam Políticas, Planos Programas ou Projetos. Havia uma discussão no Senado Federal dos EUA a respeito de propostas para uma política ambiental para o país durante a década de 1960 e, em fevereiro de 1969, foi promulgada a Lei S1075, denominada de NEPA, que propôs um programa federal de pesquisas ecológicas e a criação de um Conselho de Qualidade Ambiental (Council on Environmental Quality, que será referido como CEQ) (GLASSON; THERIVEL; CHADWICK, 2001).

Além de envolver diversas atividades humanas pontuais, tais como mineração, construção de hidreelétricas e usinas nucleares de iniciativa pública ou privada (SÁNCHEZ, 2006) o NEPA também inclui a avaliação de legislações, políticas e planos governamentais. Segundo este auto, o CEQ, formado por três membros nomeados pelo presidente com a aprovação do Senado, é um órgão fundamental para garantir o atendimento de seus objetivos, que basicamente se resumem ao cumprimento das considerações ambientais nas tomadas de decisões de forma prévia pelas agências governamentais do país. No entanto, durante a formulação do NEPA e dos requisitos da AIA serem enunciados, houve pouco cumprimento de suas resoluções tanto por parte dos empresários quanto dos burocratas, ocorrendo apenas 
quando os tribunais passaram a exigir os estudos de impacto ambiental (CALDWELL, 1977 apud SÁNCHEZ, 2006).

Sendo inicialmente concebida na década de 1970, a AIA nos EUA sofreu diversas modificações ao longo do tempo, mantendo, no entanto, seu objetivo primordial de prevenir os impactos ambientais das ações humanas de modo a influenciar os processos decisórios (SÁNCHEZ, 2006).

Após o NEPA, a AIA difundiu-se ao redor do mundo, inicialmente nos países desenvolvidos, tais como o Canadá (1973), Austrália (1974), Alemanha Ocidental (1975), França (1976) e, posteriormente, em nações menos desenvolvidas. Na década de 1980, a Diretiva Européia sobre EIA de 1985 (EC Directive 85/337) conduziu diversos países europeus a adotar suas próprias legislações e, com as transformações políticas da União Soviética em 1991, vários países do leste europeu também passaram a formular suas leis a este respeito.

No Brasil, a AIA foi introduzida como um instrumento da Política Nacional do Meio Ambiente (Lei 6938/81), e o Estudo de Impacto Ambiental (EIA) foi regulamentado pela Resolução CONAMA No 01/86.

Em 1996, mais de 100 países já possuíam, de alguma maneira, a Avaliação de Impacto Ambiental em seu ordenamento jurídico e como procedimento a ser contemplado (SADLER, 1996 apud GLASSON; THERIVEL; CHADWICK, 2001).

Os sistemas de AIA variam muito entre as nações, assumindo caráter mandatário, com procedimentos bastante detalhados e rígidos, enquanto outros se apresentam na forma de guias que, apesar de não mandatários, impõem obrigações sobre as agências governamentais responsáveis. Outros aspectos diversos em relação à AIA dizem respeito às ações em que os estudos devem ser implementados. Enquanto que nos EUA cabe às ações federais que afetem significativamente a qualidade do ambiente humano, outras nações a aplica a uma lista de projetos, como é o caso brasileiro, em que apenas a AIA para projetos (EIA) encontra-se regulamentada. Além das nações, diversas organizações multilaterais possuem algum sistema de AIA, tais como o Programa das Nações Unidas para o Meio Ambiente (1977) e o Banco Mundial (1992) (GLASSON; THERIVEL; CHADWICK, 2001).

Como dito anteriormente, a avaliação de impacto ambiental subdivide-se em avaliações de projetos, denominadas "Estudo de Impacto Ambiental" (EIA) e avaliações de Políticas, Planos e Programas, denominadas no geral de "Avaliação Ambiental Estratégica" (AAE), cujas distinções serão mencionadas a seguir. 


\subsubsection{Estudo de Impacto Ambiental: conceito, origem e procedimentos.}

O objetivo do EIA é identificar e avaliar as consequências ambientais significativas de projetos propostos (KUITUNEN; JALAVA; HIRVONEN, 2007), de modo a auxiliar as tomadas de decisão (LEKNES, 2001). Segundo este autor, uma das formas de respaldar as decisões é conceder aos seus tomadores informações sobre os possíveis impactos do projeto, de forma compreensível.

Os componentes de um EIA variam de acordo com as especificidades das nações que o implementam, mas, de forma geral, constituem-se pelos seguintes estágios:

\section{$\checkmark$ Triagem (screening):}

Compreende a identificação dos projetos que são considerados como potencialmente impactantes ao meio ambiente. Para tanto, deve-se definir previamente o que se percebe por impacto significativo e assim, identificar as ações que devem ser submetidas ao EIA. As jurisdições e organizações que adotam os estudos de impacto ambiental como instrumento de política ambiental os utiliza para fundamentar as decisões relacionadas à viabilidade ambiental de projetos que possam afetar significativamente a qualidade do meio ambiente.

No Brasil, A Constituição Federal de 1988, por meio do artigo 225, inciso IV, atribuiu ao Poder Público a exigência “[...] na forma da lei, para instalação de obra ou atividade potencialmente causadora de significativa degradação do meio ambiente, estudo prévio de impacto ambiental, a que se dará publicidade [...]". Neste sentido, cabe determinar o que seria uma atividade potencialmente causadora de significativo impacto ambiental, a fim de se estabelecer uma listagem de projetos a serem sujeitos ao EIA.

De acordo com Sánchez (2006), um impacto significativo seria sinônimo de importante, um termo bastante subjetivo, já que a importância dada às modificações ambientais depende "de seu entendimento, de seus valores, de sua percepção" (SÁNCHEZ, 2006, p.111). No entanto, devem-se estabelecer limites para o que se considera como significativo, a custo de banalizar o instrumento de política ambiental. O mesmo autor compara, a título de exemplo, os impactos ambientais advindos da instalação e operação de uma padaria e de uma usina nuclear. Para a padaria, que consome uma série de recursos naturais e gera poluentes, uma série de adequações ambientais pode ser exigida com o intuito de minimizar seus prováveis impactos negativos, como sua instalação respeitando o zoneamento municipal e a utilização de materiais obtidos de forma sustentável (madeira certificada, por exemplo). Já uma usina nuclear representa um risco à integridade do 
ecossistema e da saúde humana e, dada a experiência com desastres nucleares, os impactos ambientais ocasionados por acidentes deste montante tem o potencial de serem extremamente severos e irreversíveis. Desta forma, o instrumento para se avaliar os impactos ambientais das diversas atividades humanas deve se adequar à significância atribuída aos mesmos.

Segundo Souza (2000), dois fatores são determinantes para se estabelecer a potencial existência de um impacto ambiental: a tipologia do empreendimento (como uma barragem, distrito industrial, obra de irrigação, dentre outros) e sua localização, ou seja, o meio ambiente em que se instalará. Deste modo, a viabilidade ambiental de um projeto dependerá da vulnerabilidade ambiental do meio frente à atividade operante, ou da capacidade de suporte do meio frente aos impactos ocasionados pela mesma. Assim, o impacto ambiental decorre da interação entre as solicitações ambientais do projeto (suas pressões sobre o meio), dotado de características e processos tecnológicos inerentes e a vulnerabilidade do meio, de modo que, quanto maior a solicitação e maior a vulnerabilidade, maior é a importância ou significância do impacto.

De acordo com a pressão que uma atividade impõe ao meio ambiente, portanto, alguma forma de instrumento de política governamental pode ser aplicada, tais como pagamento de taxas, regras de zoneamento e uso do solo e/ou avaliações prévias de impacto ambiental, que condicionam o licenciamento da atividade nas etapas de sua instalação, operação e desativação. De forma geral, na maioria das nações, incluindo o Brasil, o licenciamento de projetos significativamente impactantes é condicionado à realização de um estudo prévio de impacto ambiental, ou EIA e seu respectivo relatório de impacto ambiental, ou RIMA. No entanto, outros instrumentos mais simplificados de AIA podem ser aplicados a determinadas situações ou de acordo com a legislação estadual.

O EIA/RIMA, regulamentado no Brasil pela Resolução CONAMA 01/86, apresenta alguns princípios gerais, tais como:

- a participação pública;

- o princípio da precaução;

- o princípio da publicidade

No Brasil, o EIA é relacionado diretamente ao processo de licenciamento ambiental de projetos, regulamentado pela Resolução CONAMA 237/97, definido como um procedimento administrativo que visa permitir a instalação, operação e desativação de empreendimentos tidos como potencialmente impactantes. No entanto, outras formas de estudo ambientais podem ser solicitadas ao invés do EIA, tais como: planos de controle ambiental, diagnóstico ambiental, relatório ambiental preliminar, análise de risco preliminar e planos de recuperação 
de áreas degradadas, quando se tratar de atividades que não sejam potencialmente causadoras de significativos impactos ambientais, cabendo ao órgão ambiental competente tal decisão, seja em âmbito nacional (IBAMA), estadual ou municipal (BRASIL, 1997, art. $1^{\circ}$., inciso III; art. $3^{\circ}$., parág. único).

No Brasil, o EIA/RIMA deve ser realizado às expensas do empreendedor e avaliado pelos órgãos estaduais competentes ou ao Instituto Brasileiro de Meio Ambiente (IBAMA), em caráter supletivo. As seguintes diretrizes devem ser obedecidas quando da realização de um estudo de impacto ambiental, de acordo com a Resolução CONAMA 01/86:

I - Contemplar todas as alternativas tecnológicas e de localização de projeto, confrontando-as com a hipótese de não execução do projeto;

II - Identificar e avaliar sistematicamente os impactos ambientais gerados nas fases de implantação e operação da atividade;

III - Definir os limites da área geográfica a ser direta ou indiretamente afetada pelos impactos, denominada área de influência do projeto, considerando, em todos os casos, a bacia hidrográfica na qual se localiza;

IV - Considerar os planos e programas governamentais, propostos e em implantação na área de influência do projeto, e sua compatibilidade.

(BRASIL, 1986, art. $5^{\circ}$ )

Apesar de apresentar a legislação brasileira sobre EIA, as diretrizes básicas e seu conteúdo coincidem, de forma geral, entre as diversas nações que estabeleceram legislações sobre esta questão. A listagem dos projetos a serem submetidos ao EIA varia nos diversos países e, uma vez estabelecida, o empreendedor deve realizá-lo de acordo com o conteúdo disposto na legislação, que normalmente abrange as seguintes etapas:

\section{$\checkmark$ Escopo (scoping):}

Esta fase se caracteriza pela identificação preliminar dos potenciais impactos ambientais significativos do projeto e das alternativas apresentadas (GLASSON; THERIVEL; CHADWICK; 2001). A importância em delinear apenas os impactos significativos se dá em função da delimitação dos estudos que, de forma contrária, tornar-se-iam impraticáveis, partindo-se do princípio de que a AIA deve ser aplicada para a identificação, prevenção, avaliação e gerenciamento daqueles impactos considerados significativos, evitando que se tornem apenas uma série de compilações de dados (SÁNCHEZ, 2006). No entanto, no EIA, a identificação destes impactos é preliminar, já que ao longo dos estudos, outros impactos, anteriormente considerados como não significativos poderão assim ser classificados, em um processo retroalimentado. Para tanto, nesta etapa, todas as partes interessadas no projeto em 
questão devem ser envolvidas, tais como seus proponentes, as agências reguladoras e o público, evitando e/ou mediando potenciais conflitos durante as negociações e permitindo que os recursos financeiros dispendidos com o EIA sejam alocados para as questões mais pertinentes. Nesta fase, os fatores a serem monitorados são também delimitados (GLASSON; THERIVEL; CHADWICK; 2001).

Segundo Fuggle et al (1992 apud SÁNCHEZ, 2006), a fase de escopo tem como objetivos o envolvimento das partes interessadas, a identificação e seleção das alternativas, a delimitação das questões consideradas significativas e a determinação dos termos de referência para o EIA. Além disto, é considerada uma parte fundamental do EIA, na medida em que delimita a natureza e extensão das informações ambientais requeridas para sua realização. Deste modo, caso haja um pequeno enfoque sobre os assuntos definidos como prioritários no EIA, há o risco da perda de sua objetividade e legitimidade (WOOD; GLASSON; BECKER; 2005). Uma série de critérios encontra-se consolidados pela sociedade e em legislações nacionais e tratados internacionais que auxiliam na delimitação das questões que podem ser consideradas relevantes para os EIAs, tais como:

- proteção das espécies da flora e fauna ameaçadas de extinção; - proteção dos ecossistemas que desempenham relevantes funções ecológicas, como recifes de coral, manguezais e outras áreas úmidas; - proteção de bens históricos e arqueológicos;

- proteção dos elementos do patrimônio natural, como cavernas e paisagens notáveis;

- proteção de modos de vida tradicionais e outros elementos valorizados da cultura popular;

- restrição de atividades em áreas protegidas, como parques nacionais e outras unidades de conservação;

- restrições ao uso do solo, estabelecidas em zoneamentos, planos diretores e outros instrumentos de planejamento territorial.

(SÁNCHEZ, 2006, p. 147).

Por se tratar de um estágio em que há a delimitação dos impactos significativos e que, portanto, está imbuída de interesses, a dimensão política da tomada de decisão necessita da mediação do poder das partes interessadas, já que as percepções a respeito do que pode ou não ser considerado como um impacto significativo variam de acordo com os valores e interesses da sociedade. Assim, esta fase não pode ser vista como objetiva e racional, pois se circunstancia de acordo com os agentes que determinam seu conteúdo. Apesar de sua importância, os valores ambientais da sociedade podem ou não estar representados, dependendo da forma como os estudos são conduzidos, de forma transparente e aberta ou restrita aos proponentes e avaliadores da ação (WOOD; GLASSON; BECKER; 2005). Já para 
Sánchez (2006), por envolver muitas vezes valores sentimentais, o conteúdo do EIA é uma tarefa principalmente técnica, necessitando de conhecimento especializado. Deste modo, Beanlands e Duinker (1983 apud SÁNCHEZ; 2006) propõem dois critérios para o escopo, o social, em que se busca identificar os valores sociais e traduzi-los em diretrizes para o EIA e o ecológico ou científico, em que são estabelecidos os termos para a realização dos estudos, de forma racional.

Sánchez (2006) também discorre sobre os assuntos relevantes a serem abordados no escopo do EIA, que podem ser identificados da seguinte maneira: experiência com situações similares, para a qual a opinião de especialistas faz-se muito importante; consulta ao público interessado e identificação de fatores ambientais a serem protegidos em legislação, tais como patrimônio histórico, arqueológico e paleontológico, as cavidades subterrâneas, espécies raras, áreas protegidas dentre outros.

Um dos objetos do escopo é a elaboração das diretrizes para a realização dos estudos ambientais, denominadas de termos de referência ou instruções técnicas, sendo que cada país ou agência multilateral estabelece suas próprias diretrizes. Os termos de referência podem ser conceituados como um documento que orienta a realização do EIA, definindo seu conteúdo, metodologia e abrangência. Podem ser bastante detalhados ou apresentados como diretrizes gerais. No Brasil, a Resolução CONAMA No 01/86 estabelece as seguintes diretrizes que devem nortear um EIA, sendo os termos de referência específicos para cada atividade considerada potencialmente poluidora:

- Diagnóstico ambiental da área de influência do projeto: completa descrição e análise dos recursos ambientais e suas interações, tal como existem, de modo a caracterizar a situação ambiental da área, antes da implantação do projeto, considerando:

a) o meio físico - o subsolo, as águas, o ar e o clima, destacando os recursos minerais, a topografia, os tipos e aptidões do solo, os corpos d'água, o regime hidrológico, as correntes marinhas, as correntes atmosféricas;

b) o meio biológico e os ecossistemas naturais - a fauna e a flora, destacando as espécies indicadoras da qualidade ambiental, de valor científico e econômico, raras e ameaçadas de extinção e as áreas de preservação permanente;

c) o meio sócio-econômico - o uso e ocupação do solo, os usos da água e a sócio-economia, destacando os sítios e monumentos arqueológicos, históricos e culturais da comunidade, as relações de dependência entre a sociedade local, os recursos ambientais e a potencial utilização futura desses recursos.

II - Análise dos impactos ambientais do projeto e de suas alternativas, através de identificação, previsão da magnitude e interpretação da importância dos prováveis impactos relevantes, discriminando: os impactos positivos e negativos (benéficos e adversos), diretos e indiretos, imediatos e 
a médio e longo prazos, temporários e permanentes; seu grau de reversibilidade; suas propriedades cumulativas e sinérgicas; a distribuição dos ônus e benefícios sociais.

III - Definição das medidas mitigadoras dos impactos negativos, entre elas os equipamentos de controle e sistemas de tratamento de despejos, avaliando a eficiência de cada uma delas.

IV - Elaboração do programa de acompanhamento e monitoramento (os impactos positivos e negativos), indicando os fatores e parâmetros a serem considerados.

Parágrafo Único - Ao determinar a execução do estudo de impacto Ambiental o órgão estadual competente; ou o IBAMA ou quando couber, o Município fornecerá as instruções adicionais que se fizerem necessárias, pelas peculiaridades do projeto e características ambientais da área.

(BRASIL, 1986, art. $6^{\circ}$ )

Durante a etapa de planejamento de um projeto, decisões são tomadas acerca da tipologia, escala, localização e tecnologias a serem empregadas em suas diversas fases. Neste sentido, é fundamental que alternativas tecnológicas, de localização ou até mesmo a não execução do projeto sejam consideradas para embasar a melhor decisão do ponto de vista ambiental. O US Council on Environmental Quality (CEQ) considera a proposição de alternativas como a etapa fundamental do EIA (CEQ, 1978 apud GLASSON; THERIVEL; CHADWICK, 2001). A discussão das possíveis alternativas permite que as agências reguladoras, os agentes interessados e o empreendedor levem em conta diversas abordagens do projeto, minimizando potenciais danos ambientais e também as soluções mais benéficas financeiramente. Segundo Sánchez (2006):

[...] A busca e a comparação de alternativas é um dos pilares da avaliação de impacto ambiental, que tem como uma de suas funções 'incitar os proponentes a conceber projetos ambientalmente menos agressivos e não simplesmente julgar se os impactos de cada projeto são aceitáveis ou não'.

(SÁNCHEZ, 1993, p.21 apud SÁNCHEZ, 2006, p.152)

Vários tipos de alternativas devem ser consideradas na fase de planejamento do projeto, tais como “opção de 'não ação', alternativas locacionais, de escalas do projeto, de processos ou equipamentos, de layouts, de condições de operação e formas de lidar com os impactos ambientais" (GLASSON; THERIVEL; CHADWICK, 2001, p.93). A opção de "não ação" refere-se à descontinuidade do projeto, se justificado do ponto de vista ambiental e é requerida em diversos países, como nos EUA (GLASSON; THERIVEL; CHADWICK, 2001) e no Brasil: 
Artigo $9^{\circ}$ - O relatório de impacto ambiental - RIMA refletirá as conclusões do estudo de impacto ambiental e conterá, no mínimo:

[...] V - A caracterização da qualidade ambiental futura da área de influência, comparando as diferentes situações da adoção do projeto e suas alternativas, bem como com a hipótese de sua não realização;

(BRASIL, 1986, art. $9^{\circ}$, inciso V)

Também na referida Resolução CONAMA No 01/86, a contemplação das alternativas locacionais e tecnológicas do projeto é obrigatória para os EIAs/RIMAs. A opção de "não ação" diz respeito à avaliação da necessidade do projeto, que depende de seus custobenefícios. A consideração das alternativas locacionais é um componente importante ao EIA, possibilitando a escolha da melhor opção em termos ambientais, sociais e logísticos, como, por exemplo, em projetos industriais, que se beneficiam de locais em que haja infraestrutura adequada, proximidade de mercados, fontes de matéria-prima, demanda social para o trabalho e outras. Do ponto de vista ambiental, a localização em áreas de elevada vulnerabilidade ambiental para esta atividade apresenta-se como uma restrição ao projeto, a não ser que o mesmo se adeque tecnologicamente ao local, de forma a evitar potenciais impactos ambientais significativos. Alternativas em termos de extensão do projeto também devem ser analisadas, permitindo uma maior flexibilidade de acordo com as condições ambientais, o mesmo se dando para as alternativas tecnológicas e de processos, que seriam formas de alcançar o mesmo objetivo por outros meios (GLASSON; THERIVEL; CHADWICK, 2001).

Mais do que a decisão de aceitar ou não o projeto, o objetivo de uma AIA é propor soluções criativas para projetos formulados de modo tradicional, por meio do levantamento de alternativas em todos os sentidos já abrangidos. Sem esta meta, a AIA perderia seu sentido de atestar a viabilidade ambiental das ações propostas (SÁNCHEZ, 2006). A participação dos setores interessados no projeto é crucial nesta etapa de planejamento, possibilitando que as alternativas menos aceitáveis sejam eliminadas ao mesmo tempo em que outras sejam sugeridas, por meio de um processo de negociação entre as partes. Neste momento, as informações sobre as condições do meio e das características do projeto devem ser disponibilizadas para a consulta pública, assim como as alternativas apresentadas pelo proponente. Diversas metodologias podem ser utilizadas para apresentar e analisar as informações obtidas, tais como: geoprocessamento, matrizes de impacto, checklists, dentre outras (GLASSON; THERIVEL; CHADWICK, 2001).

\section{$\checkmark$ Estudos de Base/ Base Ambiental (baseline studies; environmental baseline)}


A base ambiental têm por objetivo fornecer as informações necessárias para as etapas seguintes do EIA, tais como a previsão e avaliação dos impactos ambientais. No entanto, os dados a serem coletados são definidos na etapa anterior, de escopo, em que os potenciais impactos ambientais são levantados, com intuito de concentrar nas questões mais importantes e, consequentemente, evitar desperdícios financeiros e de tempo. Após definidas as informações necessárias, necessita-se estabelecer as escalas temporal e espacial para os estudos e os métodos de coleta, processamento e interpretação dos dados (SÁNCHEZ, 2006). De acordo com este autor, as funções do estudo de base seriam:

- fornecer informações necessárias para a identificação e previsão dos impactos, e para sua posterior avaliação;

- contribuir para a definição de programas de gestão ambiental (medidas mitigadoras, compensatórias, programas de monitoramento e demais componentes de um plano de gestão ambiental integrante de um EIA);

- estabelecer uma base de dados para futura comparação com a real situação, em caso de implementação do projeto.

(SÁNCHES, 2006, p. 218)

Segundo Glasson; Therivel e Chadwick (2001) a base ambiental tem como intuito apresentar o estado atual do meio ambiente em que o projeto poderá ser inserido, a fim de compará-lo com as potenciais mundanças ocasionadas pela implementação da atividade. Para tanto, deve-se considerar a dinâmica do sistema analisado e suas modificações que resultarão de eventos naturais e de origem antrópica. Os componentes do meio a ser analisado abrangem tanto sua dimensão biofísica quanto sócio-econômica. Para estes autores, o período a ser considerado nas previsões deve se basear no ciclo de vida do projeto.

Existem duas tipologias de informações a serem obtidas em um EIA: os dados primários e os secundários. Os primários consistem em informações preexistentes e encontram-se em instituições públicas de pesquisa, em órgãos ambientais ou coletados pelo proponente da ação, enquanto que os secundários são mais específicos para o EIA da atividade em questão e demandam trabalhos de campo custosos em termos financeiros e de tempo. Deste modo, observa-se a importância de se dirigir os estudos para as questões relevantes, de modo a evitar informações obtidas desnecessariamente (SÁNCHEZ, 2006; GLASSON; THERIVEL; CHADWICK, 2001). No entanto, à medida que o estudo transcorre, novos impactos podem ser previstos, que necessitarão de novas informações. Daí a etapa de escopo se caracterizar por uma delimitação dos aspectos previamente considerados 
importantes, podendo-se incorporar novas questões ao longo de todo o processo do EIA (GLASSON; THERIVEL; CHADWICK, 2001).

Inicialmente, a área de estudo necessita ser definida para a coleta de dados, ou seja, o local em que o projeto será instalado, para depois identificar sua área de influência, que pode ser definida como "a área cuja qualidade ambiental sofrerá modificações direta ou indiretamente decorrentes do empreendimento" (SÁNCHEZ, 2006, p.170). Uma base ambiental é imprescindível, deste modo, para o monitoramento da área afetada pelo projeto, já que uma de suas funções é apresentar a situação do meio ambiente antes da instalação e operação do projeto, a qual pode ser comparada ao longo de seu ciclo de vida, momento nos quais os impactos ambientais poderão ocorrer de fato.

Percebe-se que a função da base ambiental extrapola a simples coleta de informações atuais do meio que será afetado pelo projeto para uma situação que permita aos analistas lidar com a dinâmica ambiental da área em questão, possibilitando a identificação mais detalhada dos potenciais impactos, a adoção de medidas que os previnam e o monitoramento ambiental. Segundo Sánchez, a base ambiental possibilita (2006, p.219):

[...] uma descrição e análise da situação atual de uma área de estudo feita por meio de levantamentos de componentes e processos do meio ambiente físico, biótico e antrópico e de suas interações, o que é usualmente chamado de diagnóstico ambiental, um retrato da situação pré-projeto, ao qual virá se contrapor um prognóstico ambiental, ou seja, uma projeção da provável situação futura do ambiente potencialmente afetado, caso a proposta em análise seja implementada; também se pode fazer um prognóstico ambiental considerando que a proposta em análise não seja implementada.

(SÁNCHEZ, 2006, p.219)

Deste modo, a próxima etapa do EIA consiste na realização da análise dos potenciais impactos ambientais previamente levantados, denominada de prognóstico ambiental.

\section{$\checkmark$ Prognóstico ambiental: avaliação dos impactos ambientais}

A previsão dos impactos ambientais significativos necessita do conhecimento das características do projeto considerando seu ciclo de vida e as alternativas locacionais. Um levantamento prévio dos impactos ambientais significativos (positivos e negativos) é realizado na fase de escopo, mas novas indagações podem surgir ao longo do EIA, na medida em que as informações sobre o projeto e o meio ambiente são mais bem analisadas. Segundo 
Glasson; Therivel e Chadwick (2001), a escolha do(s) método(s) para a identificação dos impactos deve levar em consideração os seguintes elementos:

- os requisitos dispostos em regulamentações;

- a abrangência dos impactos, em suas dimensões social, física e econômica;

- a distinção entre as tipologias de impactos, ou seja, entre positivos e negativos, extensos ou diminutos, de curto ou longo prazo, reversíveis ou irreversíveis;

- a identificação dos impactos secundários e cumulativos e não somente os diretos;

- a distinção entre impactos significantes e insignificantes;

- a comparação entre as alternativas propostas ao projeto;

- a capacidade de suporte ambiental frente aos impactos potenciais;

- as informações qualitativas e quantitativas;

- ser compreensível e pouco custoso;

- resultados consistentes e não enviesados, ou seja, transparente.

Existe uma série de metodologias a disposição dos analistas para a identificação dos impactos, muitas das quais desenvolvidas como resposta às exigências do NEPA, envolvendo mecanismos simples e de fácil utilização aos mais complexos, dependendo das regulamentações específicas de cada país e do tipo de projeto. De modo geral, podem ser classificados como: listagens de controle ou checklists, matrizes de impactos, métodos quantitativos (tais como modelos matemáticos), redes de interação, sobreposição de mapas dentre outros.

Após realizada a predição dos impactos, segue-se sua avaliação, em que serão atribuídos seus graus de significância. Os métodos utilizados para tanto variam de mais simplistas aos mais complexos, quantitativos ou qualitativos, sendo os mais utilizados as análises de custo-benefício, análises multicritério, método Delphi, dentre outros (GLASSON, THERIVEL; CHADWICK, 2001).

A avaliação dos impactos envolve a identificação da magnitude e significância das modificações ambientais resultantes de uma ação, comparando-a com a situação sem a implementação do projeto. A magnitude geralmente se relaciona a um padrão limite, geralmente definido em legislação, como os padrões limites da água e do ar, sendo mais objetivos de se determinar, enquanto que a significância depende de uma abordagem mais subjetiva, pois envolve o julgamento de valores. (GLASSON, THERIVEL; CHADWICK, 2001, SÁNCHEZ, 2006). 
A avaliação de impactos também envolve sua identificação em impactos benéficos ou adversos, diretos, indiretos, sinergísticos, aditivos e cumulativos, além de sua dimensão geográfica, duração e permanência, tendo em conta as modificações acarretadas ao longo do ciclo de vida do projeto, pois as interações ambientais não são lineares. A determinação dos impactos cumulativos é uma tarefa muito complexa e, muitas vezes, são omitidos ou pouco analisados nos EIAs. Uma dimensão que é inerente tanto na fase de previsão quanto na avaliação de impactos é a incerteza, a qual pode afetar a acurácia da previsão. As incertezas podem ser incorporadas de diversas formas no EIA: os pressupostos da análise devem ser bastante claros, assim como as probabilidades e seus desvios-padrão (quando da utilização de modelos estatísticos) ou de forma descritiva. Como forma de lidar com as incertezas presentes nas avaliações de impactos, a comparação com outras situações similares é um fator importante como, por exemplo, o conhecimento acumulado com o monitoramento de projetos com características semelhantes à atividade em análise. Por conta disto, o EIA deve se constituir em um processo adaptativo, constantemente sujeito a revisões. Daí a importância do monitoramento ao longo da fase de vida do projeto (GLASSON, THERIVEL; CHADWICK, 2001).

Os métodos de avaliação a serem utilizados dependem da natureza do impacto e dos recursos disponíveis, de acordo com as alternativas levantadas, o nível de informações e as características do público envolvido. Assim como para a previsão dos impactos, os métodos variam dos mais simples aos mais complexos, quantitativos e qualitativos, formais ou informais e dependem essencialmente da experiência dos analistas envolvidos e da percepção pública. A metodologia mais simples de avaliação é a comparação dos potenciais impactos frente aos requerimentos e padrões dispostos em legislação (tais como os padrões de qualidade da água e do ar). A atribuição do grau de significância necessita da aplicação de pesos distintos aos impactos identificados, determinando uma comparação para identificar os mais importantes, o que envolve juízos de valor, tornando esta a fase mais difícil do EIA (SÁNCHEZ, 2006). Segundo este autor, avaliar um impacto significa classificá-lo, separandoo de acordo com seu grau de importância. O princípio da avaliação é dado durante o escopo, no entanto, a previsão dos impactos e a determinação de sua magnitude e significância permitem um conhecimento maior para realizar a classificação segundo sua importância.

Em razão da subjetividade inerente à avaliação dos impactos, é importante que sejam clarificados os julgamentos baseados em valores estabelecidos por grupos sociais e pela equipe técnica. De forma geral, a etapa de previsão dos impactos é mais objetiva e, portanto, dotada de uma cientificidade maior, enquanto que a avaliação é uma fase que requer uma 
análise subjetiva (SÁNCHEZ, 2006). Segundo Beadlands (1993, p.61 apud SÁNCHEZ, 2006, p.289) e Erickson (1994 apud SÁNCHEZ, 2006, p.289), deveriam ser considerados significativos os impactos que:

- afetem a saúde ou a segurança do homem;

- afetem a disponibilidade de empregos ou recursos à comunidade local;

- afetem a média ou variância de determinados parâmetros ambientais (significância estatística);

- modifiquem a estrutura ou função dos ecossistemas ou coloquem em risco espécies raras ou ameaçadas (significância ecológica);

- o público considere importante;

(BEADLANDS, 1993, p.61 apud SÁNCHEZ, 2006, p.289)

No Brasil, a regulamentação de AIA foi feita por intermédio da Resolução CONAMA No 01/86 que estabelece a consideração dos seguintes atributos na avaliação dos impactos ambientais: benéficos ou adversos; diretos ou indiretos; imediatos, de médio ou longo prazo; temporários ou permanentes e reversíveis ou irreversíveis.

Diversas metodologias podem ser utilizadas para a avaliação dos impactos ambientais previstos, tais como (SÁNCHEZ, 2006):

- Combinação de atributos: procura definir os atributos dos impactos (“característica ou propriedade de um impacto [...] usada para descrevê-lo ou qualificá-lo, como sua expressão, origem e duração, entre outros" (SÁNCHEZ, 2006, p.296)), criando-se uma escala para cada impacto e combinando-os segundo critérios de avaliação. Por exemplo, pode-se escolher os atributos magnitude e reversibilidade, com as seguintes escalas:

* magnitude: pequena, média, grande;

* reversibilidade: reversível, irreversível.

Combinando-se estes atributos e escalas, se tem os seguintes arranjos entre os tipos de impactos:

* reversível com pequena magnitude;

* reversível de média magnitude;

* reversível de grande magnitude;

* irreversível de pequena magnitude;

* irreversível de média magnitude;

* irreversível de grande magnitude.

Quanto aos critérios de avaliação, podem ser adotados, como exemplo, os seguintes: os impactos irreversíveis são de grande importância; os reversíveis com pequena ou média 
magnitude tem pequena importância e os impactos reversíveis de grande magnitude possuem importância média.

\section{$\checkmark$ Comparação entre as alternativas e tomada de decisão:}

Realizadas as etapas de previsão e avaliação de impactos ambientais do projeto e suas alternativas locacionais e/ou tecnológicas levantadas na fase de escopo ou em etapas posteriores, é possível selecionar a alternativa mais adequada do ponto de vista ambiental e também sócio-econômico. Como explicitado anteriormente, a participação dos interessados no projeto em todas as fases do EIA é fundamental para tal escolha, a fim de conferir legitimidade e transparência durante o procedimento (SÁNCHEZ, 2006).

Segundo Souza (2000), a AIA deve contemplar a análise do binômio tipologialocalização, ou seja, verificar a capacidade do meio e a viabilidade ambiental do empreendimento.

\section{$\checkmark$ Monitoramento:}

Diversos países, dentre os quais se encontra o Brasil, possui em suas legislações sobre EIA o monitoramento ambiental da atividade ao longo de seu ciclo de vida: planejamento, instalação, operação e desativação, visando a detecção de possíveis alterações ambientais previstas ou não. Para tanto, é necessário definir os indicadores ambientais que serão monitorados, de forma prévia. Diversos autores (GLASSON; THERIVEL; CHADWICK, 2001; SCHMIDT; JOÃO; ALBRECHT, 2005; SÁNCHEZ, 2006) sustentam que a importância do monitoramento não se dá apenas para verificação dos impactos e em sua mitigação, mas também para a gestão ambiental adaptativa do projeto, que pode conduzir à alterações em seu formato por meio de modificações tecnológicas nos processos que sejam a causa dos impactos detectados. Além disto, possibilita a agregação de conhecimentos sobre a tipologia do projeto e os potenciais impactos ambientais que possam ocasionar no ambiente receptor, que servirão de base para futuros EIAs.

\subsubsection{Avaliação Ambiental Estratégica: conceito, origem e procedimentos.}

Nas etapas iniciais de planejamento de ações estratégicas e como mecanismo de avaliação em suas diversas etapas de realização, uma ferramenta de AIA que vem sendo 
globalmente utilizada é a Avaliação Ambiental Estratégica a qual, segundo Sadler e Verheem, 1996 apud Therivel et al. (2004, p.6) consiste em um:

[...] processo sistemático de avaliação das consequiências ambientais de políticas, planos e programas propostos com intuito de garantir que as mesmas estejam completamente incluídas nos estágios iniciais apropriados da tomada de decisão, em conjunto com considerações econômicas e sociais.

Segundo João (2005), o principal papel da AAE é informar os tomadores de decisão sobre as consequências ambientais das PPPs. Exemplificam com uma política nacional de transporte, plano local de desenvolvimento e um programa para a construção de uma série coordenada de barragens. São várias as definições de Políticas, Planos e Programas encontradas na literatura, que podem ser apresentadas da seguinte forma, segundo estes mesmos autores:

- Política: “[..] uma inspiração e guia para a ação [...]” (JOÃO, 2005, p.4), como a promoção ou não de energia nuclear em uma nação. Ou, segundo Sadler; Verheem, 1996 apud Partidário (2002, p.48) uma "linha de conduta geral ou direção que o governo está ou estará adotando, apoiada por juízos de valor que orientem seus processos de tomada de decisão".

- Plano: "[..] uma série de ações propostas combinadas, com um tempo de conclusão específico, que implementam a Política, como a quantidade de energia nuclear a ser produzida até 2020" (JOÃO, 2005, p.4). Também pode ser definido como uma "estratégia composta de objetivos, alternativas e medidas, incluindo a definição de prioridades, elaborada para viabilizar a implementação de uma política" (SADLER; VERHEEM, 1996 apud PARTIDÁRIO, 2002, p. 48).

- Programa: “[...] uma série de ações propostas relacionadas em um área determinada, que irá implementar um Plano, por exemplo, a proposta de quatro usinas nucleares com capacidade $\mathrm{X}$ na área Y para o ano de 2020" (JOÃO, 2005, p.4). Definido também como uma "agenda organizada dos compromissos, propostas, instrumentos e atividades necessárias para implementar uma política, podendo estar ou não integrada a um Plano" (SADLER; VERHEEM, 1996 apud PARTIDÁRIO, 2002, p. 48).

Therivel e Brown (1999 apud THERIVEL, 2004, p.09) definem como ações estratégicas e, portanto, passíveis de sujeitarem a uma AAE, os seguintes exemplos:

- legislação: nacional, regional, local; tratados internacionais $[\ldots]$;

- políticas econômicas, financiamentos, planejamento fiscal, ex. 
ajustamentos estruturais, privatização, subsídios, taxação, acordos comerciais;

- planos de desenvolvimento integrados: nacional, regional/territorial, local/cidade; programas com projetos múltiplos; áreas de conservação (World Heritage, parques nacionais);

- políticas setoriais, planos e programas em escalas amplas, ex. para agricultura, transporte, resíduos sólidos;

- políticas, planos e programas para a gestão de recursos específicos em escalas territoriais amplas, ex. gestão costeira, manejo florestal, gestão de águas; e

- políticas, planos e programas para alcançar fins sociais, ex. desenvolvimento de empregos, acesso equitativo ao transporte, auxílios internacionais.

As ações estratégicas geralmente são desenvolvidas por órgãos governamentais, mas também podem incluir companhias privadas ou semi-privadas, e são caracterizadas por possuírem "um ou mais objetivos, adicionados a detalhamentos sobre como o(s) objetivo(s) será(serão) implementado(s)" (THERIVEL et al., 1994, p.10).

\section{$\checkmark$ Histórico da AAE}

A primeira legislação que propôs a necessidade da AAE foi o US National Environmental Policy Act (NEPA), de 1969, nos EUA e que requeria a avaliação de impactos ambientais das principais ações governamentais que poderiam ocasionar impactos ambientais significativos, sendo o termo "principais ações governamentais" posteriormente definido pelo Council on Environmental Quality (CEQ), abrangendo legislações, regulamentações, políticas, planos, programas, projetos e procedimentos propostos pelas agências governamentais (JOÃO, 2005). No entanto, não foram delimitadas distinções entre os procedimentos para a AAE e o EIA, sendo as avaliações de PPPs denominadas de formas variadas, tais como avaliações programáticas, regionais, cumulativas ou genéricas (SIGAL; WEBB, 1989 apud SCHMIDT; JOÃO, ALBRECHT, 2005). O CEQ determinou que as avaliações programáticas de impactos deveriam abranger uma série de ações governamentais para garantir que os impactos ambientais cumulativos fossem considerados e que as questões abrangidas no estudo não fossem repetidas nos EIAs, o que foi denominado posteriormente de avaliação em cascata, ou seja, seguindo uma hierarquia. No entanto, apesar da legislação estadunidense abarcar formas de AAE, o que predominou ao longo das décadas seguintes foram os EIAs (CEQ, 1978 apud SCHMIDT; JOÃO; ALBRECHT, 2005).

Na União Européia, a necessidade de um instrumento que possibilitasse a avaliação de 
PPPs e não somente de projetos vinha sendo discutida desde 1975, quando se intencionou criar uma Diretiva que abrangesse tanto a AIA de ações estratégicas quanto pontuais. Mas, quando a Diretiva sobre o EIA foi aprovada em 1985, apenas a avaliação de projetos foi considerada (THERIVEL et al., 1994).

Com a prática do EIA consolidando-se mundialmente, uma série de dificuldades quanto o cumprimento das funções que foram atribuídas a este instrumento passaram a ser detectadas e, portanto, sua capacidade para promover o desenvolvimento sustentável foi posta em dúvida. Mesmo com a ampla adoção deste instrumento e da elaboração de bons guias e legislações, a degradação ambiental permanece sendo um grande problema em todo o mundo, tanto nos países em desenvolvimento (ALSHUWAIKHAT, 2005) quanto nos desenvolvidos que tem por modelo um elevado consumo de recursos naturais.

Dentre as limitações do EIA, podem ser citadas (THERIVEL et al., 1994; SCHMIDT; JOÃO; ALBRECHT, 2005; ALSHUWAIKHAT, 2005):

Dificuldades em considerar os impactos cumulativos, indiretos e sinergísticos dos projetos, que deveriam ter em vista os impactos advindos das diversas atividades similares instaladas próximas entre si, em um recorte territorial não abrangido pelo EIA, que estuda apenas os projetos individuais. Os impactos cumulativos das diversas políticas, planos e programas relacionados também não são avaliados;

O EIA é um estudo reativo a uma determinada proposta de desenvolvimento, com horizonte de curto prazo;

$\checkmark$ A não inserção do projeto em um planejamento estratégico impossibilita que impactos ambientais significativos sejam identificados previamente, conduzindo ao elevado custo operacional do EIA, que requer uma série de dados brutos e estudos que poderiam ser considerados em etapas anteriores do planejamento;

$\checkmark$ Dificuldades em levantar alternativas tecnológicas, locacionais e de modelos de desenvolvimento, já que outras atividades propostas na área em estudo não são consideradas. Deste modo, a instalação de atividades pode e geralmente é realizada em áreas ambientalmente frágeis, já que não existe um diagnóstico ambiental prévio do local. Diferentemente do EIA, a AAE possibilita que se considerem diversos modelos de desenvolvimento e alternativas locacionais para alcançar o mesmo objetivo, nos casos em que esteja disponibilizado o diagnóstico ambiental, principalmente em se tratando de alternativas locacionais;

O EIA é utilizado para a aprovação ou não de projetos, ou seja, para o licenciamento ambiental, o que envolve um planejamento operacional da atividade em questão, enquanto 
que a AAE é um instrumento de planejamento que visa aprimorar as PPPs, não submetendoas ao licenciamento;

$\checkmark$ Em sua grande maioria, o EIA é realizado sem um planejamento estratégico prévio que permite analisar alternativas de desenvolvimento em horizontes temporais amplos. Isto se deve ao fato de o EIA avaliar uma atividade que já se encontra proposta, levando em conta apenas o ciclo de vida, quando muito, da atividade isolada. Deste modo, a tomada de decisões sobre os modelos de desenvolvimento são tomadas tardiamente. O EIA termina por reagir a propostas de desenvolvimento, ao invés de antecipá-las;

$\checkmark$ Apesar da exigência de monitoramento ambiental nas etapas de instalação, operação e desinstalação do projeto na maior parte das legislações nacionais sobre EIA, este fato não é cumprido, o que impossibilita a detecção de possíveis impactos ambientais durante o ciclo de vida do projeto e não gera o acúmulo de conhecimento necessário para futuros EIAS de atividades similares;

$\checkmark$ A condução de um EIA sem o planejamento ambiental não permite que ações preventivas sejam tomadas, já que há grandes dificuldades em considerar alternativas, impactos cumulativos, indiretos e sinergísticos, e não há retroalimentação dos estudos, pela falta de monitoramento. Diversas vezes os impactos de um único projeto sobre um ou mais fatores ambientais pode se mostrar não significativo, mas quando combinados com outras ações, podem resultar em impactos significantes. Dado que o EIA avalia apenas um projeto individual, estes impactos não são previstos e apenas medidas mitigadoras podem ser tomadas, quando muito;

$\checkmark$ Nos países em desenvolvimento, o próprio instrumento EIA demonstra-se inefetivo devido à ausência de capacidade organizacional, difusão de experiências e entraves políticos.

Deste modo, a necessidade em desenvolver um modelo de AAE foi levada em conta por diversas organizações internacionais, a fim de que as relações entre desenvolvimento e meio ambiente fossem consideradas. Dada esta natureza de acoplar as considerações ambientais, sociais, culturais e econômicas com participação social e um amplo horizonte temporal, diversos governos e organizações multilaterais têm visto na AAE um importante instrumento para o processo contínuo de desenvolvimento sustentável (ALSHUWAIKHAT, 2005). Como exemplos de organizações e tratados internacionais que demandaram às nações a consideração da questão ambiental em todas as etapas das tomadas de decisão podem ser citados o Banco Mundial, desde 1987, o relatório Brundtland de 1987, a Agenda 21 e a Declaração do Rio de Janeiro elaborada durante a Eco 92 no Rio de Janeiro, em 1992 e a United Nations Economic Comission for Europe, também de 1992. 
De acordo com Therivel (2004), até 2003 aproximadamente vinte nações haviam incorporado requerimentos legais para a $\mathrm{AAE}$ em seus arcabouços legislativos, tendo por base dois modelos emergentes: a Diretiva Européia 2001/42/EC e o SEA Protocol da UNECE, originados com o intuito de diversas nações acordarem sobre um sistema universal de AAE, abrangendo uma ampla gama de ações estratégicas. Segundo Jones et al. (2005), este número vem crescendo em virtude também da exigência da realização de AAE para Planos e Programas de financiamento aos países em desenvolvimento por parte do Banco Mundial, que elaborou procedimentos próprios para o estudo.

A Comissão Européia tem discutido a necessidade de realizar AIAs para PPPs desde a década de 70, por considerar que o EIA ocorre tardiamente no processo de planejamento. $\mathrm{O}$ termo "avaliação ambiental estratégica" surge durante estas discussões:

As avaliações ambientais apropriadas às políticas, planos e programas são de natureza mais estratégica do que aquelas aplicadas à projetos individuais e se predispõem a diferir destes em diversos aspectos importantes... Nós temos adotado o termo 'avaliação ambiental estratégica' (SEA) para descrever este tipo de avaliação.

(WOOD; DJEDDOUR (1989), p.v. ${ }^{1}$ apud JONES et al., 2005, p.16)

Diversos países já adotaram ou estão em vias de implementar sistemas de AAE, com suas particularidades metodológicas e de âmbito de aplicação, dentre os quais podem-se citar: Holanda, Dinamarca, Reino Unido, França, Alemanha, Suécia, Finlândia, Polônia, República Tcheca, Letônia, Estônia, Portugal, Escócia, Islândia, Hungria, EUA, Nova Zelândia, Canadá, Quênia, Gana, Ucrânia, China, África do Sul, Chile, Brasil, dentre outros (THERIVEL et al., 1994; SCHMIDT; JOÃO; ALBRECHT, 2005; ALSHUWAIKHAT, 2005).

Ao inserir a questão ambiental nas propostas governamentais, a AAE é um instrumento que aprimora a ação estratégica, possibilitando caminhos que conduzam a um desenvolvimento mais sustentável do ponto de vista ambiental e, consequentemente, social, cultural e econômico (ALSHUWAIKHAT, 2005)

Os modelos de AAE mais estudados e que servem de base para o desenvolvimento da AAE em âmbito mundial são a Diretiva Européia 2001/42/EC e o UNECE Protocol, os quais serão, portanto, brevemente analisados neste trabalho.

\section{- Diretiva Européia 2001/42/EC}

Na União Européia, a idéia de se desenvolver um sistema de AAE surge durante a 
criação da Diretiva Européia sobre o EIA, por volta de 1975, com a intenção de estabelecer uma Diretiva que abrangesse tanto a AIA para PPPs quanto para projetos. No entanto, somente a Diretiva para projetos foi implementada (WOOD, 1988 apud THERIVEL, 2004). Dada a ausência de um guia europeu sobre AAE, diversos países-membro desenvolveram seus próprios sistemas desde a década de 80, como a Holanda, que estabeleceu uma AIA para alguns Planos e Programas e um e-test para políticas e legislações; a Dinamarca, que implantou uma AAE para propostas governamentais e o Reino Unido, que desenvolveu uma forma de AAE para as autoridades de planejamento locais, denominada de environmental appraisal. No entanto, o objetivo econômico de integração entre os países-membro da União Européia, o qual se estendia a outros setores, dentre os quais o ambiental, levou à necessidade de se estabelecer um guia comum para a AIA de PPPs em toda a comunidade (THERIVEL, 2004).

Deste modo, o quinto programa de ação ambiental da UE, englobando o período de 1993 a 2000, apresentou-se como um impulsionador para a criação da AAE, dado seu caráter antecipatório. A implementação do desenvolvimento sustentável nas PPPs européias promoveu a necessidade de se incluir as questões ambientais nas tomadas de decisão dos países-membros. Deste modo, em 21 de julho de 2001, a Diretiva Européia sobre AAE foi publicada, com o objetivo de "prover um elevado nível de proteção ao meio ambiente e contribuir para a integração das considerações ambientais na preparação e adoção de planos e programas com a visão de promover um desenvolvimento mais sustentável" (UNIÃO EUROPÉIA, 2001, art. 1 apud JONES et al, 2005, p. 16). A avaliação de políticas governamentais não se encontra presente, portanto, na AAE da União Européia, e é baseada fortemente na Diretiva sobre o EIA, tanto que a AAE é solicitada somente para os planos e programas que possam levar aos empreendimentos que sejam passíveis de EIA, com exceção para os Planos e Programas que requeiram avaliações ambientais nos termos da Diretiva 92/43/CEE de 1992, relativa à proteção dos habitats naturais e da fauna e flora selvagens. Já para os Planos e Programas que possam ocasionar alterações pouco significativas ao meio ambiente, fica a critério dos países-membros realizarem ou não uma AAE (JONES et al, 2005; UNIÃO EUROPÉIA, 2001). Dentre os PPs sujeitos à AAE se encontram, principalmente, aqueles relacionados ao planejamento territorial, como o setor de energia, transporte, habitação, dentre outros.

Tal Diretiva requer o acesso à informação acerca dos Planos e Programas analisados, tanto às autoridades competentes quanto ao público; a realização de consulta pública; um Relatório Ambiental, sintetizando os estudos realizados durante a AAE e o monitoramento 
ambiental. Com relação às consultas públicas, a Diretiva permite que os estudos sejam disponibilizados durante a preparação do Plano ou Programa e antes de sua adoção, enquanto que a Diretiva sobre o EIA requer apenas uma explanação a respeito dos motivos que conduziram às decisões já tomadas. Deste modo, a AAE confere às tomadas de decisão uma maior transparência (THERIVEL, 2004).

Apesar de não delimitar as metodologias a serem utilizadas nos estudos, a Diretiva levanta alguns aspectos que devem ser considerados, tais como (UNIÃO EUROPÉIA, 2001, anexo 01):

- Os objetivos dos PPs e suas relações com outros que lhe sejam pertinentes;

- O atual estado do ambiente e sua provável condição caso o Plano ou Programa não sejam efetuados;

- As características da(s) região(ões) afetada(s) pelos PPs;

- Os impactos ambientais potenciais ocasionados pelos PPs, principalmente os relacionados às zonas de especial proteção ambiental. Devem-se considerar impactos significativos sobre a fauna, flora, solo, água, atmosfera, fatores climáticos, patrimônio cultural (arquitetônico e arqueológico), bens materiais, paisagens e suas interrelações;

- Os objetivos ambientais determinados internacional ou localmente e as formas como são considerados pelos PPs durante sua preparação;

- Medidas para prevenir e mitigar os potenciais impactos;

- Um resumo técnico contendo a escolha das alternativas, incluindo a metodologia utilizada e as dificuldades encontradas durante os estudos, incluindo a ausência de informações. Neste aspecto, difere fundamentalmente do EIA, que requer apenas a análise das principais alternativas levantadas no momento em que a atividade e a localização já se encontram pré-definidas, enquanto que a AAE requer a identificação e estudo das alternativas levantadas previamente, antes da concepção das atividades;

- O monitoramento dos PPs, que não se encontra na Diretiva do EIA.

- A Diretiva apresenta também alguns critérios a serem utilizados para a determinação da probabilidade dos impactos negativos dos PPs, assim como as características dos impactos e das áreas que lhe são suscetíveis (UNIÃO EUROPÉIA, 2001, anexo II). Devido ao fato de não apresentar procedimentos para a realização dos estudos da AAE e não restringir os Planos e Programas a serem avaliados pelos países-membro, a Diretiva Européia possibilita a estes uma maior flexibilidade para que adotem legislações sobre AAE adaptadas a seus contextos institucionais (RISSE et al., 2003 apud JONES et al, 2005). 
A Diretiva Européia sobre AAE deveria ter sido adotada em todos os países-membro até 21 de julho de 2004. No entanto, diversas nações ainda não possuem sistemas de AAE em seus arcabouços legais (THERIVEL et al., 2004).

\section{- SEA Protocol da UNECE}

O Protocolo da United Nations Economic Comission for Europe (UNECE) é mais extenso e complexo do que a Diretiva Européia sobre a AAE e suplementa a Convenção sobre a Avaliação de Impacto Ambiental em Contexto Transfronteiriço (Convention on Environmental Impact Assessment in a Transboundary Context), a Espoo Convention, além de vir ao encontro da Convenção de Aarhus (Convention on Access to Information, Public Participation in Decision-making and Acces to Justice in Environmental Matters). Foi desenvolvida pela ONU e adotada por 35 países em 23 de maio de 2003, em Kiev (Ucrânia). A UNECE abarca os países europeus, os EUA, Canadá, países caucasianos e Ásia Central, mas qualquer país pertencente à ONU pode fazer-lhe parte. As semelhanças e diferenças entre a Convenção e a Diretiva Européia podem ser assim resumidas (THERIVEL, 2004):

Semelhanças:

- Requer AAE para os mesmos tipos de Planos e Programas;

- Um relatório ambiental contendo basicamente as mesmas informações, apesar da maior necessidade de se explicitar os impactos transfronteiriços;

- A necessidade de participação do público interessado é semelhante. No entanto, explicita que a consulta às autoridades de saúde e o envolvimento do público pode se fazer presente durante a fase de escopo do estudo;

- Os resultados das consultas e as razões para a tomada de decisão devem ser mencionadas e tornadas públicas;

- O monitoramento dos potenciais impactos significativos é obrigatório.

Diferenças:

- A definição de "meio ambiente" é menos explícita, mas inclui a saúde como sua integrante, devido à participação da OMS em sua preparação;

- É mais explícito quanto à participação do público, incluindo-a durante a fase de escopo, assim como à sua consulta, em acordo com a Convenção de Aarhus;

- Também engloba as políticas e legislações a serem sujeitas à AAE; 


\section{$\checkmark$ Princípios da AAE}

A AAE se faz necessária ao desenvolvimento de ações estratégicas com implicações ambientais, seja de Políticas, Planos ou Programas, por permitir uma análise sistemática dos objetivos almejados de forma independente, minimizando seu direcionamento aos interesses de grupos setorizados; pela possibilidade da proposição de alternativas, avaliação de suas consequências e de sua negociação com setores mais amplos da sociedade; pelo embasamento científico e maior legitimidade social na escolha da(s) melhor(es) alternativa(s) apresentada(s); pela consideração e análise de outras ações estratégicas relacionadas, diminuindo possíveis confrontos existentes, além do mecanismo de retroalimentação fornecido pelo monitoramento das ações propostas (THERIVEL et al., 1994; THERIVEL, 2004). Os princípios da AAE são, de forma geral (THERIVEL et al., 1994; THERIVEL, 2004; JOÃO, 2005; ALSHUWAIKHAT, 2005; PARTIDÁRIO, 2007):

$\checkmark$ Instrumento adequado para a implementação dos princípios do desenvolvimento sustentável, por considerar as variáveis ambientais e, por vezes, sociais e econômicas nas etapas de planejamento. Possibilita a aplicação do princípio da precaução, caso haja ausência de certezas quanto aos potenciais danos ambientais significativos;

$\checkmark$ É uma ferramenta para o aprimoramento da ação estratégica, podendo conduzir a sua modificação em termos de objetivos, formas de alcance e implementação, caso seja considerada nos estágios iniciais dos processos de tomadas de decisão;

A participação dos atores interessados deve ocorrer nas diversas etapas do planejamento da ação estratégica, tornando o processo mais transparente, robusto e efetivo, garantindo também os mecanismos de prestações de contas e uma boa governança ambiental. A participação social nas tomadas de decisões estratégicas é fundamental para a identificação dos conflitos e mediação dos interesses dos atores afetados pelas políticas públicas, possibilitando o conhecimento sobre os múltiplos aspectos da realidade e as alternativas para a solução dos problemas existentes, de forma legítima e transparente. Para tanto, é indispensável a inclusão de grupos sociais marginalizados nos processos decisórios, os quais, não tendo acesso aos veículos de informação e representação política, acabam muitas vezes sendo negativamente afetados pelas decisões tomadas. Experiências com questões polêmicas na União Européia, como energia nuclear e até mesmo a regulação de OGMs têm demonstrado a importância da consulta e participação social de modo pró-ativo e não apenas reativamente (O'CONNOR; van den HOVE, 2001). Rowe e Frewer (2004, apud Guivant (2005) definem participação pública como uma prática de consulta e envolvimento do público 
na formulação de agendas políticas e processos decisórios realizada pelo governo ou instituições responsáveis pelo desenvolvimento de políticas públicas;

$\checkmark$ Enfoca aspectos importantes da ação estratégica, com um nível menor de detalhamento do que uma avaliação pontual, como o EIA;

$\checkmark$ Por permitir que a AIA se dê "em cascata”, ou seja, de forma hierarquizada no sentido das políticas aos projetos, evita que as análises prévias sobre os potenciais impactos de um modelo de desenvolvimento sejam repetidas no EIA, tornando-o mais dinâmico e menos custoso. Em algumas situações, este instrumento pontual pode até não se mostrar necessário, em função dos estudos prévios realizados;

$\checkmark$ Auxilia na escolha da melhor opção em se tratando de meio ambiente, o que envolve a consideração e análise de diversas alternativas, que podem incluir a opção de não adotar a estratégia ou continuar com as tendências atuais, a redução da demanda como, por exemplo, a reutilização da água e diminuição do consumo de energia e outros recursos naturais, a consideração de diferentes tipos de desenvolvimento visando os mesmos objetivos, alternativas locacionais, dentre outras. É importante frizar que as alternativas abordadas podem não ser excludentes, mas sim integradas;

$\checkmark$ Possibilita a minimização de impactos negativos, a otimização dos positivos e a compensação pela perda de características e benefícios valiosos. A AAE deve ser instrumento de aplicação do princípio da precaução, ou seja, quando os impactos ambientais de determinadas ações forem incertos, deve-se proteger os valores ambientais existentes, optando-se em algumas situações, pela não ação. Ao invés de buscar por soluções mitigadoras fim-de-tubo, pode considerar a modificação da ação proposta visando a prevenção dos impactos;

$\checkmark$ Permite também a prevenção dos impactos negativos e dos conflitos sociais advindos das diversas propostas nas etapas de planejamento estratégico;

$\checkmark$ Tem o potencial de impor limites aos danos ambientais identificados na estratégia, de modo a se respeitar a capacidade de suporte do meio, o que requer a predição dos impactos, além da comparação da situação futura sem e com a implementação da ação proposta. Uma ampla representação dos interessados é necessária nas etapas de avaliação de impactos, cuja atribuição de significância depende de juízos de valores;

$\checkmark$ Pelo fato de as etapas estratégicas conduzirem e delinearem os empreendimentos pontuais, uma ferramenta que possibilite sua avaliação oferece a chance de influenciar as tipologias dos projetos futuros, ao invés de detalhá-los e avaliá-los somente após sua concepção; 
$\checkmark$ A AAE lida com impactos difíceis de serem considerados no âmbito do projeto, possibilitando a análise de impactos cumulativos, sinérgicos e de largo espectro espacial e temporal que envolve a multiplicidade de projetos. Desta forma, atitudes precaucionistas e/ou preventivas podem ser melhor identificadas e aplicadas;

$\checkmark$ Incorpora considerações sobre meio o ambiente e a sustentabilidade, em outros âmbitos que não apenas os econômicos imediatos; Possibilita uma maior compreensão acerca da ação estratégica e suas conexões e efeitos sobre ações correlatas;

$\checkmark$ Permite a integração institucional, por considerar as demais PPPs relacionados à ação estratégica em análise.

$\checkmark$ A exigência do monitoramento ambiental desde as etapas prévias do planejamento e após sua aplicação possibilita uma gestão ambiental adaptativa, com mecanismos de prevenção e mitigação de impactos mais eficazes que no EIA;

Possibilita uma melhor governança ambiental.

Assim como para o EIA, a aplicação da AAE também possui uma série de limitações, tais como (THERIVEL, 1994):

$\checkmark$ Elevado grau de incertezas na previsão dos impactos ambientais, em função da imprecisão espacial dada pela menor resolução das informações ambientais;

$\checkmark$ Falta de informações a respeito da natureza, escala e localização de futuras propostas de desenvolvimento, dificultando a previsão dos impactos potenciais;

$\checkmark$ Ausência, em maior ou menor grau de acordo com o país em questão, de articulação institucional, dificultando a preparação de políticas comuns e evitando sua duplicação e as possíveis contradições derivadas;

$\checkmark$ Diversas nações carecem de sistemas de planejamento, principalmente de longo prazo, reagindo às demandas imediatas que se concretizam na fase de projetos;

$\checkmark$ Dificuldades em inserir a variável ambiental no planejamento estratégico, com a preponderância dos interesses econômicos;

Metodologias de $\mathrm{AAE}$ ainda não bem definidas, principalmente quanto às formas de participação pública e predição e avaliação dos impactos indiretos e cumulativos, de longo prazo;

Por se tratar de um instrumento de AIA relativamente recente, a definição e forma de implantação da AAE são bastante variáveis entre os países. Em razão disto, alguns estudos que são considerados como sendo AAEs são bastante questionáveis, assemelhando-se por vezes a EIAs de grandes projetos;

Um fator importante a ser considerado é o fato de a AAE não ter como objetivo 
substituir o EIA, que possui suas atribuições específicas, mas sim complementá-lo e antecedêlo por meio de um planejamento ambiental prévio, considerando impactos em escalas temporais e espaciais amplas, tais como os impactos cumulativos e indiretos. Além disto, permite uma avaliação ambiental adaptativa e minimiza os gastos do EIA em termos financeiros e temporais para a execução dos estudos. No estado da Califórnia, nos EUA, por exemplo, a AAE tem permitido que projetos subseqüentes ao planejamento não requeiram avaliações muito detalhadas (JOÃO, 2005). A relação entre a AAE e o EIA pode ser ilustrada pela seguinte figura:

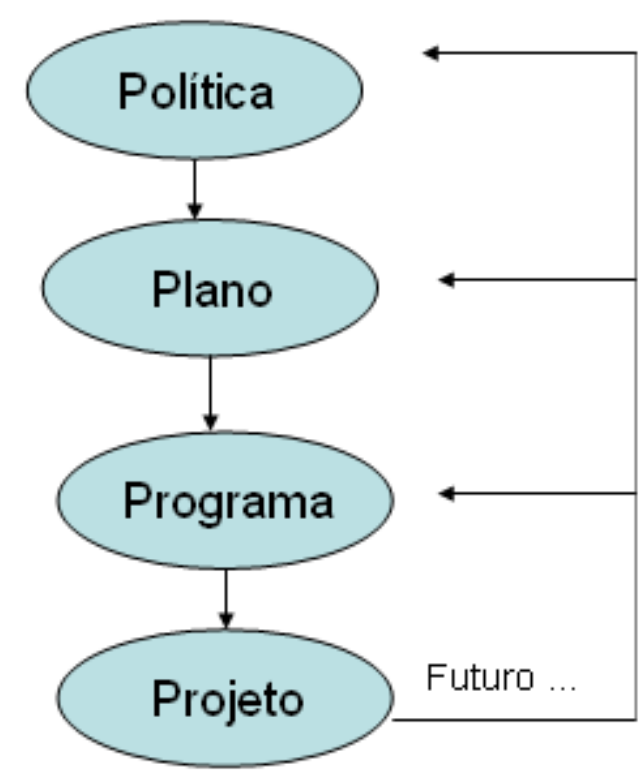

Figura 06: Relações hierárquicas entre Políticas, Planos, Programa e Projetos. Fonte: Adaptado de João (2005, p.4).

Por esta figura torna-se claro que as políticas influenciam a formulação de planos os quais podem levar à elaboração de programas e estes em projetos correlacionados, em um processo hierárquico ou "em cascata". A AAE seria, portanto responsável pela AIA dos PPPs, enquanto o EIA, apenas dos projetos, sendo o último elo da relação. Este modelo, que demonstra um planejamento ambiental, evita que existam duplicações de análises entre os diversos estágios. No entanto, os projetos podem levar, futuramente, à modificação dos elos anteriores da cadeia (JOÃO, 2005), de forma a gerar mecanismos adaptativos, na medida em que surjam novas demandas sociais e informações sobre o estado do meio ambiente.

A Tabela 44 ilustra as diferenças entre o Estudo de Impacto Ambiental e a Avaliação Ambiental Estratégica: 
Tabela 44 - Diferenças entre o Estudo de Impacto Ambiental e a Avaliação Ambiental Estratégica.

\begin{tabular}{|c|c|}
\hline AAE & EIA \\
\hline Instrumento de planejamento ambiental. & Instrumento de licenciamento ambiental \\
\hline $\begin{array}{l}\text { Avalia Políticas, Planos e Progamas (ações } \\
\text { estratégicas). }\end{array}$ & Avalia projetos/empreendimentos pontuais. \\
\hline $\begin{array}{l}\text { Recortes territoriais amplos (nacional, estadual, } \\
\text { regional, municipal) }\end{array}$ & $\begin{array}{l}\text { Recortes territoriais reduzidos (âmbito do } \\
\text { Projeto) }\end{array}$ \\
\hline $\begin{array}{l}\text { Possibilita análise ampla de alternativas: } \\
\text { - De modelos de desenvolvimento; } \\
\text { - Locacionais; } \\
\text { - Tecnológicas; }\end{array}$ & $\begin{array}{l}\text { Alternativas restritas ao projeto: } \\
\text { - Tecnológicas; } \\
\text { - Operacionais }\end{array}$ \\
\hline Estudos de base ambiental menos detalhados. & $\begin{array}{l}\text { Maior nível de detalhamento nos estudos de } \\
\text { base ambiental. }\end{array}$ \\
\hline $\begin{array}{l}\text { Participação social em todas as etapas de } \\
\text { planejamento. }\end{array}$ & $\begin{array}{l}\text { Participação social apenas nas fases de } \\
\text { licenciamento do projeto }\end{array}$ \\
\hline Considera impactos cumulativos e indiretos. & $\begin{array}{l}\text { Impactos indiretos e cumulativos difíceis de } \\
\text { serem avaliados. }\end{array}$ \\
\hline $\begin{array}{l}\text { Monitoramento da estratégia, sendo um processo } \\
\text { contínuo de retroalimentação. Permite o } \\
\text { aprimoramento da estratégia e o aprendizado. }\end{array}$ & $\begin{array}{l}\text { Monitoramento é exigido legalmente mas não } \\
\text { é realizado na prática. Impactos ambientais } \\
\text { não são detectados. }\end{array}$ \\
\hline
\end{tabular}

Fonte: Modificado de Therivel et al. (1994) e Partidário (2002).

Segundo João (2005) e Partidário (2007) a AAE não se objetiva somente a avaliar a ação estratégica, mas também influenciar em sua elaboração, melhorando-a de acordo com as conclusões dos estudos, o que contribui para o processo de tomada de decisões que se dão em momentos diversificados. Caso a AAE seja realizada paralelamente sem a integração nas etapas de planejamento, sua influência sobre as decisões será diminuta. João (2005) apresenta quatro possíveis modelos de interação entre a AAE e as etapas decisórias que ocorrem durante o planejamento: 


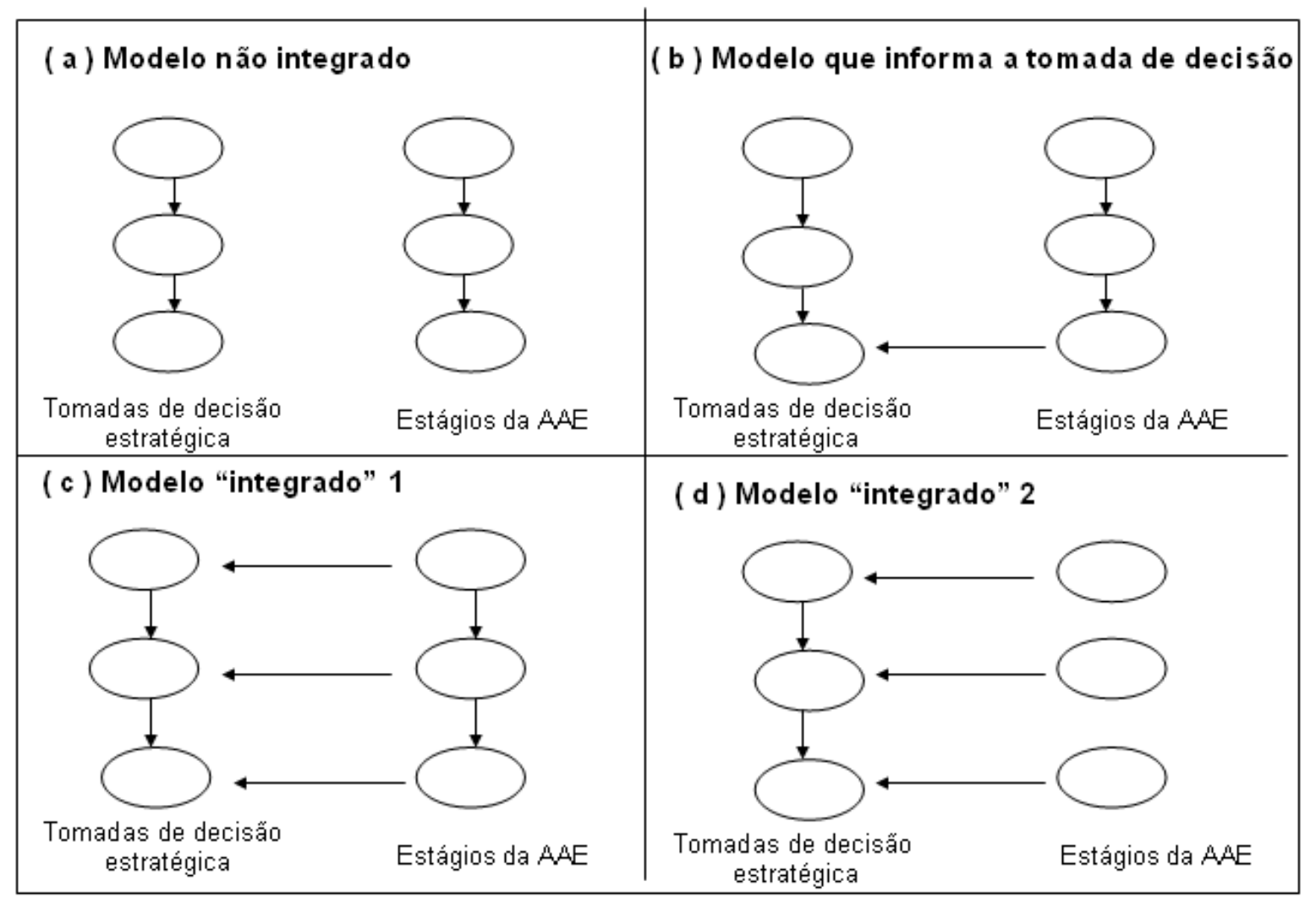

Figura 07: Ligação (ou não) entre os estágios de tomadas de decisão estratégica e as fases da AAE - círculos simbolizam os estágios e as flechas indicam as relações. (a) e (b) não são modelos de boas práticas, enquanto que (c) e (d) são considerados modelos de "boas práticas".

Fonte: Adaptado de João (2005, p. 9).

O modelo (a) representado acima demonstra uma prática comum em que a AAE é realizada como uma avaliação paralela às etapas de planejamento, não influenciando em absoluto as tomadas de decisões. O modelo (b) apresenta a AAE informando seus resultados e possivelmente interferindo na fase final da estratégia. Por conta disto, tais aplicações da AAE são consideradas impróprias, por não interferirem no formato da Política, Plano ou Programa analisados. Já os modelos (c) e (d) são denominados "integrados" porque estabelecem um elo de ligação entre as múltiplas etapas decisórias do planejamento com as etapas da AAE, possibilitando às autoridades competentes pela PPP se informar a respeito dos resultados da AAE ao longo da elaboração da ação estratégica e utilizar as análises para tomar suas decisões (JOÃO, 2005). Para melhor ilustrar a forma como os modelos integrados influenciam as etapas da estratégia, observa-se a figura 09, que tem por base o modelo integrado II: 


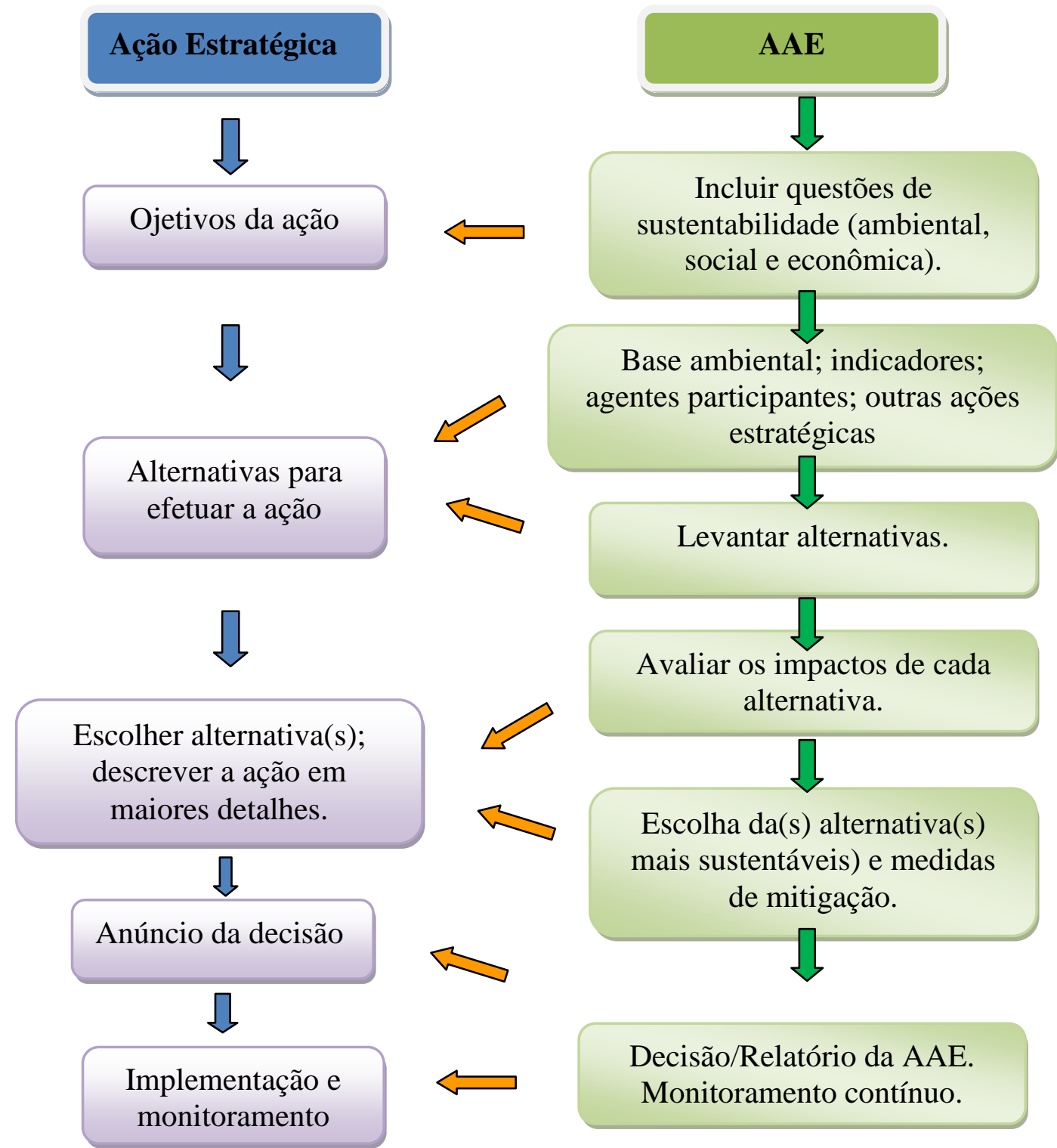

Figura 08: Estágios da ação estratégica e a forma como estes podem ser influenciados pela AAE.

Fonte: Modificado de Therivel (2004).

Sendo o objetivo da AAE a inserção da variável ambiental na elaboração das PPPs, avaliando sua viabilidade ambiental e melhorando suas estratégias de forma a alcançar a sustentabilidade ambiental, os objetivos da ação estratégica podem ser remodelados em um modelo integrado. Como exemplo, a Oxford Brookes University (2004 apud JOÃO, 2005) apresenta uma estratégia de transporte que inicialmente tinha como objetivo garantir o tráfego de todas as formas de transporte e melhorar a economia regional ao mesmo tempo em que se minimizassem os impactos ambientais derivados do uso de veículos motorizados. No entanto, algumas contradições foram encontradas nesta proposta, já que poderia conduzir ao aumento do número de veículos, que não necessariamente garantiria o acesso da população aos meios 
de transporte, além de ocasionar problemas ambientais. A elaboração de uma AAE levou à reformulação deste objetivo, que passou a ser o aumento da acessibilidade e a redução da necessidade de se utilizar veículos motorizados de transporte. Deste modo, a AAE contribuiu para mitigar os possíveis impactos negativos e maximizar os positivos da referida estratégia. Daí a importância da AAE "ser iniciada previamente, integrada ao processo decisório e focar nas alternativas potenciais e nas modificações da ação estratégica" (LEVETT; THERIVEL, 2003 apud JOÃO, 2005).

Para Partidário (2002) dentre os princípios a serem adotados para que se estabeleçam boas práticas de AAE, podem-se citar:

$\checkmark$ A existência de um referencial político de sustentabilidade, em que se encontrem definidos os objetivos e metas de qualidade ambiental e de desenvolvimento sustentável. As prioridades e as questões ambientais significativas devem ser delimitadas, evitando que aspectos pouco importantes sejam levantados no contexto da avaliação da ação estratégica, o que tornaria o processo muito complexo;

$\checkmark$ A AAE deve se encontrar diretamente relacionada com as tomadas de decisão, interferindo nas etapas de elaboração da ação estratégica, como anteriormente observado nos modelos integrados de AAE;

$\checkmark$ Existência de um contexto institucional consolidado, com a definição das atribuições e responsabilidades das instituições envolvidas. Para tanto, a regulamentação geral da AAE deve ser definida em legislação específica, preferencialmente. Como parte da regulamentação ou guia da AAE, deve-se estabelecer quais tipos de políticas, planos e programas devem ser submetidos à avaliação;

$\checkmark$ Integração dos aspectos ambientais, sociais, econômicos, institucionais e políticos na avaliação;

$\checkmark$ Definição clara dos objetivos da AAE, seus termos de referência, com utilização de metodologias simples;

$\checkmark$ Acesso público aos estudos e relatórios;

$\checkmark$ Monitoramento e acompanhamento das estratégias adotadas, com revisões sempre que se fizer necessário.

\section{$\checkmark$ Experiência internacional com AAE}

Como visto anteriormente, a AAE assume diversas formas, de acordo com o arranjo político e institucional do país ou agência multilateral em que é implantada. 
De acordo com UNITED NATIONS ENVIRONMENTAL PROGRAMME (2004), as políticas podem ser estabelecidas de formas diferentes, incluindo guias, legislações e estratégias. Dado este grau de flexibilidade, a AAE geralmente assume vários procedimentos para se adequar à sua elaboração, estando sua aplicação sujeita a resistências de ordem burocrática e política, o que a torna muito difícil. Além disto, o desenvolvimento de políticas geralmente não é realizado de forma sistemática e racional, necessitando de abordagens de AAE mais flexíveis, adequadas ao contexto institucional do país (NILSSON, DALKMANN, 2001). Tais autores defendem a idéia de que somente com a compreensão do processo decisório é possível inserir ou melhorar as considerações ambientais, por meio de AAE e EIA.

Alguns países, como a Dinamarca e Holanda, aplicam a AAE durante o esboço das legislações, em um processo rápido, mínimo, com uma breve documentação dos prováveis impactos ambientais decorrentes das propostas. O e-test é utilizado na Holanda em conjunto com testes regulatórios e econômicos e leva em conta quatro questões de sustentabilidade (UNITED NATIONS ENVIRONMENTAL PROGRAMME, 2004):

- Os efeitos da legislação sobre o consumo de energia e mobilidade;

- Os efeitos da legislação sobre o consumo das matérias-primas existentes;

- Efeitos da legislação sobre as emissões de resíduos no ar, solo e água;

- Efeitos da legislação sobre o uso do espaço físico.

Entretanto, estudos recentes vêm demonstrando que estes testes apresentam pouco impacto sobre a elaboração de legislações, por se dar em estágios avançados de sua proposição, em que as alternativas são mais difíceis de serem consideradas (UNITED NATIONS ENVIRONMENTAL PROGRAMME , 2004).

O Canadá também aplica a AAE em políticas, planos e programas que são sujeitos à aprovação pelo Gabinete. Cada departamento governamental deve considerar os efeitos ambientais de suas PPPs, que devem ser submetidas ao Conselho de Ministros na forma de um relatório constando uma declaração formal ao público sobre tais efeitos e, se possível, uma consulta pública. Aplica-se à proposta estratégica de políticas e legislações uma lista de questões, estabelecendo-se metas ambientais e de sustentabilidade. Quanto aos Planos e Programas, exige-se uma AAE mais formal, com a utilização de matrizes de impactos, envolvendo o público, preferencialmente (PARTIDÁRIO, 2002, UNITED NATIONS ENVIRONMENTAL PROGRAMME, 2004). O Reino Unido utiliza a AAE para políticas de forma não mandatária, como parte de uma avaliação abrangente de políticas que é centrada em análises de custo-benefício, com uma aplicação inconsistente. Na África do Sul, a AAE de 
políticas também é realizada de forma voluntária (UNITED NATIONS ENVIRONMENTAL PROGRAMME, 2004).

Países em transição, dotados de formulações políticas mais centralizadas e sistemáticas geralmente aplicam métodos de AIA baseados em EIA, com uma avaliação detalhada de impactos ambientais e provisões para a participação pública, como são os casos da Rússia, Eslováquia e Ucrânia. Na Eslováquia, por exemplo, a AAE de políticas e planos é utilizada nas seguintes situações (UNITED NATIONS ENVIRONMENTAL PROGRAMME, 2004): políticas de desenvolvimento nas áreas de energia, mineração, indústria, transporte, florestas, gestão de águas e resíduos sólidos, agricultura, turismo; planos territoriais em áreas especiais do ponto de vista ambiental; propostas legislativas que potencialmente ocasionem impactos ambientais negativos.

As aplicações iniciais de AAE em Planos e Programas se deram na Califórnia, EUA, por meio do US Federal and Californian EIA systems. O NEPA, anteriormente discutido, possui provisões para a utilização de avaliação de impactos programática para projetos que tenham características tipológicas comuns. Além dos EUA, Holanda e República Tcheca também adotam AAE para Planos e Programas em alguns setores, tais como planos territoriais, gestão de resíduos, energia e abastecimento de água. A União Européia, por meio da Diretiva sobre AAE também torna obrigatória a aplicação de AAE para PPs que acarretam empreendimentos avaliados em EIA (UNITED NATIONS ENVIRONMENTAL PROGRAMME, 2004).

Nos países em desenvolvimento, o Banco Mundial tem sido um propulsionador da criação de legislações específicas para $\mathrm{AAE}$ em setores de desenvolvimento, como requisito para seus investimentos, por meio da Avaliação Ambiental Setorial, principalmente nas áreas de transporte, indústria, energia, agricultura, água e resíduos sólidos. Geralmente, a AAE desenvolvida pelo Banco Mundial busca avaliar os aspectos legais, institucionais e regulatórios da gestão ambiental do país que solicita investimento em determinada área setorial, visando auxiliar a nação a incluir a preocupação ambiental nas etapas de planejamento setorial. No entanto, a utilização de AAE nestes países tem se mostrado incipiente e limitada, com exceção de algumas nações ou agrupamento de países, como a África do Sul, o Leste da Ásia e do Pacífico. No entanto, estudos realizados pelo Banco Mundial demonstram que a AAE tem obtido pouca influência sobre os processos decisórios no planejamento setorial das nações em desenvolvimento (BANCO MUNDIAL, 1996 apud UNITED NATIONS ENVIRONMENTAL PROGRAMME, 2004).

As dificuldades de implantação de sistemas de $\mathrm{AAE}$ ao redor do mundo se dão devido 
ao desconhecimento sobre os processos de planejamento das propostas estratégicas, quando de sua presença, fato fundamental para que a AAE influencie em sua formulação (THERIVEL; PARTIDÁRIO, 1996 apud NILSSON; DALKMANN, 2001). Enquanto as metodologias de avaliação de impactos ambientais, seja o EIA ou a AEE baseiam-se em modelos racionais de tomadas de decisão, em que existe uma sequiência lógica de formulação de objetivos, levantamento e escolha das melhores alternativas e suas consequiências, os processos decisórios praticados são influenciados por comportamentos intuitivos e de natureza política, não seqüenciais como no modelo de decisão racional. Em realidade, as tomadas de decisão envolvem fatores que contradizem a teoria do racionalismo nos processos decisórios, tais como os interesses políticos e anseios pessoais de seus agentes, conflitos, ausência de legitimidade e transparência, o que os torna permeados de incertezas. $O$ envolvimento de diversas organizações e suas influências, a ausência de conhecimento e divergências sobre a definição dos problemas e a imprevisibilidade colaboram para o elevado grau de incertezas na formulação de estratégias governamentais (NILSSON: DALKMANN, 2001). No entanto, para que haja modificações graduais nas decisões, se faz necessária a criação de uma rede de atores sociais que sejam capazes de interferir nos processos decisórios, em uma forma mais democrática e participativa. Deste modo, é possível que, dentre as alternativas viáveis, surja um "meio-termo" que se ajuste à complexidade dos interesses em jogo, ao invés da idealização da melhor alternativa possível para a solução de problemas, em um modelo decisório de "racionalismo imperfeito" (SIMON, 1976 apud NILSSON, DALKMANN, 2001).

Apesar da variedade de procedimentos existentes em AAE, como as metodologias aplicadas na avaliação de políticas e legislações, baseadas geralmente em testes ambientais de caráter informal, a AAE utilizada em Planos e Programas apresenta comumente algumas etapas que se assemelham aos estágios do EIA. A tabela 45, elaborada por Therivel (2004) apresenta os estágios da AAE, as decisões a serem tomadas em cada etapa e os resultados a serem relatados: 
Tabela 45 - Passos da AAE comumente utilizados na avaliação de Planos e Programas.

\begin{tabular}{|c|c|c|}
\hline Estágios da AAE & O que decidir & O que relatar \\
\hline $\begin{array}{l}\text { 1. Identificar os objetivos da } \\
\text { AAE, indicadores e metas. }\end{array}$ & $\begin{array}{l}\text { Quais os objetivos ambientais e } \\
\text { de sustentabilidade, metas e/ou } \\
\text { indicadores para testar as } \\
\text { opções e enunciados do plano. }\end{array}$ & $\begin{array}{l}\text { Lista dos objetivos da } \mathrm{AAE} \text {, } \\
\text { indicadores e metas quando } \\
\text { relevantes. }\end{array}$ \\
\hline $\begin{array}{l}\text { 2. Descrever a base ambiental, } \\
\text { incluindo tendências futuras; } \\
\text { identificar questões e problemas } \\
\text { ambientais. }\end{array}$ & $\begin{array}{l}\text { Quais questões e problemas } \\
\text { ambientais e de sustentabilidade } \\
\text { a serem consideradas durante as } \\
\text { tomadas de decisão. }\end{array}$ & $\begin{array}{l}\text { Dados da base ambiental; lista } \\
\text { das questões e problemas } \\
\text { ambientais e de sustentabilidade } \\
\text { relevantes. }\end{array}$ \\
\hline $\begin{array}{l}\text { 3. Identificar as ligações com } \\
\text { outras ações } \\
\text { relevantes. }\end{array}$ & $\begin{array}{l}\text { Quais as outras ações } \\
\text { estratégicas influenciam a } \\
\text { estratégia em questão e como. }\end{array}$ & $\begin{array}{l}\text { Lista das ações estratégicas } \\
\text { relevantes, e quaisquer conflitos } \\
\text { ou problemas com a estratégia } \\
\text { em questão. }\end{array}$ \\
\hline $\begin{array}{l}\text { 4. Identificar alternativas (mais) } \\
\text { sustentáveis para lidar com os } \\
\text { problemas e implementar os } \\
\text { objetivos da ação estratégica. }\end{array}$ & $\begin{array}{l}\text { ivas ou opções a } \\
\text { rados. }\end{array}$ & Lista das alternativas ou opções. \\
\hline $\begin{array}{l}\text { 5. Preparar o Relatório do } \\
\text { Escopo; consulta. }\end{array}$ & $\begin{array}{l}\text { O que incluir no Relatório do } \\
\text { Escopo. }\end{array}$ & $\begin{array}{l}\text { Resultados dos estágios } 1 \text { a } 4 \text {; } \\
\text { declaração escrita acordada } \\
\text { sobre como proceder com os } \\
\text { estágios subseqüentes. }\end{array}$ \\
\hline $\begin{array}{l}\text { 6. Prever e avaliar o impacto } \\
\text { das alternativas/enunciados; } \\
\text { comparar alternativas; mitigar } \\
\text { os impactos da(s) } \\
\text { alternativa(s)/enunciado(s) } \\
\text { escolhido(s). }\end{array}$ & $\begin{array}{l}\text { Quais os efeitos das } \\
\text { alternativas/opções } \\
\text { enunciados sobre os objetivos e } \\
\text { indicadores ambientais e de } \\
\text { sustentabilidade; quais as } \\
\text { alternativas preferidas; quais } \\
\text { medidas mitigadoras a serem } \\
\text { incluídas. }\end{array}$ & $\begin{array}{l}\text { Sumários dos efeitos das } \\
\text { alternativas/opções } \\
\text { enunciados sobre o meio } \\
\text { ambiente e a sustentabilidade; } \\
\text { lista das alternativas preferidas; } \\
\text { explanação dos motivos de } \\
\text { terem sido preferidas; propostas } \\
\text { de mitigação. }\end{array}$ \\
\hline $\begin{array}{l}\text { 7. Escrever o Relatório da } \\
\text { AAE; estabelecer guias para a } \\
\text { implementação. }\end{array}$ & $\begin{array}{l}\text { Como apresentar os dados dos } \\
\text { estágios } 1 \text { a } 6 .\end{array}$ & Preparar o Relatório da AAE. \\
\hline 8. Consulta & $\begin{array}{lll}\text { Quem } & \text { consultar; } & \text { como } \\
\text { responder } & \text { aos resultados das } \\
\text { consultas. }\end{array}$ & $\begin{array}{l}\text { Como os resultados da consulta } \\
\text { foram considerados. }\end{array}$ \\
\hline $\begin{array}{l}\text { 9. Monitorar os impactos } \\
\text { ambientais/de sustentabilidade } \\
\text { da ação estratégica. }\end{array}$ & $\begin{array}{l}\text { Como lidar com os impactos } \\
\text { negativos da ação estratégica. }\end{array}$ & $\begin{array}{l}\text { Como os impactos da ação } \\
\text { estratégica serão monitorados e } \\
\text { serão lidados os efeitos } \\
\text { significativos. }\end{array}$ \\
\hline
\end{tabular}

Fonte: Adaptado de Therivel (2004, p.16)

\section{Screening:}

Esta primeira etapa consiste em decidir qual ação estratégica será submetida à AAE e seus procedimentos, assemelhando-se em seus propósitos, à fase de Escopo do EIA. Para tanto, o país que elaborar um sistema de AAE deve estabelecer um conjunto de normas ou regras em âmbito nacional contendo as categorias de estratégias às quais a $\mathrm{AAE}$ se fará necessária. Cada nação possui seus próprios requerimentos de escolha como, por exemplo, o 
NEPA (EUA), que aplica a AAE às principais ações federais que tenham o potencial de ocasionar impactos ambientais significativos, na forma de Avaliação Ambiental Programática. O Banco Mundial a requer para ações de desenvolvimento setorial e regional; a Dinamarca, às propostas parlamentares e a Nova Zelândia à PPPs que afetem potencialmente o meio ambiente (SADLER, 2003 apud THERIVEL, 2004).

\section{A International Association for Impact Assessment (INTERNATIONAL} ASSOCIATION FOR IMPACT ASSESSMENT, 2005) desenvolveu um guia específico para inserir a questão da biodiversidade na etapa de screening de PPPs, por meio da identificação dos potenciais impactos das ações propostas no âmbito de ecossistemas, espécies e genótipos. Para tanto, é importante considerar:

- os impactos sobre áreas protegidas e que servem de habitat para espécies-chave;

- impactos sobre áreas não protegidas legalmente, mas que sejam importantes para a conservação da biodiversidade;

- PPPs e atividades que possam causar danos significativos à biodiversidade, considerando o tipo, duração, magnitude e reversibilidade dos impactos;

- impactos sobre áreas que provêem importantes serviços ambientais, tais como proteção de componentes abióticos, como solo e água e também daqueles que sejam importantes do ponto de vista cultural.

Para tanto, um mapeamento destas áreas e uma Política ou Estratégia de Biodiversidade nos âmbitos nacional, estadual, regional e municipal devem ser consideradas durante esta etapa da AAE (INTERNATIONAL ASSOCIATION FOR IMPACT ASSESSMENT, 2005).

\section{* Escopo}

Anteriormente à proposição dos procedimentos da AAE, devem-se identificar as etapas decisórias da ação estratégica, de modo que haja uma integração entre ambas. Neste sentido, se fazem necessárias para influenciar a estratégia a identificação de momentos de decisão durante a elaboração da proposta, que são denominados de "janelas de decisão" (decision windows) pelo ANSEAN Team (2002 apud THERIVEL 2004). Uma importante decisão a ser tomada durante esta fase é a concepção da AAE como um sistema avaliatório em separado ou integrado com outras formas de avaliação como, por exemplo, as de cunho econômico, de saúde, dentre outras. No entanto, uma crítica levantada por Therivel (2004) e outros autores (OLIVEIRA, 2009) é a perda do impacto que a AAE poderia trazer para a 
formulação e avaliação da estratégia, já que os aspectos ambientais podem ser pouco considerados em detrimento dos econômicos e sociais, como é comumente feito nas na prática decisória.

Antes da preparação da AAE definem-se também os atores sociais que irão participar de seu processo. Para Therivel (2004), ao menos três grupos devem estar envolvidos: os tomadores de decisão e seus consultores, organizações ambientais e público interessado. Quanto a quem deve conduzir ou elaborar a AAE, a autora sugere um trabalho conjunto entre especialistas e autoridades governamentais, diferentemente do EIA, que é realizado apenas por consultores. Deste modo, aspectos importantes da avaliação podem ser garantidos, tais como: transparência, independência e objetividade, com o acompanhamento do público durante ou após finalizada a avaliação (por meio de audiências públicas, painéis de cidadãos, dentre outros métodos). As formas e os momentos de participação pública na AAE é uma questão bastante discutida e em andamento, cabendo a cada nação identificar as melhores práticas para garantir que o público efetivamente participe de algum modo nas tomadas de decisão. Sua importância para a AAE é imprescindível, pois garante um maior conhecimento sobre as condições locais em que a ação estratégica será conduzida; auxilia na identificação dos problemas ambientais; diminui os conflitos sociais que possam ser gerados, tornando a estratégia mais efetiva; permite que a população reflita e tome decisões baseadas em suas aspirações futuras, aprimorando a prática democrática; possibilita que alternativas inovadoras e mais condizentes com as realidades locais sejam abordadas, sua escolha e as medidas preventivas e mitigadoras mais adequadas (THERIVEL, 2004; UNITED NATIONS ENVIRONMENTAL PROGRAMME, 2004).

Segundo UNITED NATIONS ENVIRONMENTAL PROGRAMME (2004), a característica de retroalimentação ou gestão adaptativa da AAE requer uma participação contínua da sociedade, em todos os seus estágios, de preparação, avaliação e revisão das estratégias analisadas. No entanto, tal prática é comumente impossibilitada em diversas nações que não proporcionam abertura democrática na formulação de suas políticas. Como sugestões para tornar a participação efetiva, concreta e não muito onerosa, a organização sugere que sejam empregadas técnicas de grupos focais, por meio da atuação de representantes dos setores interessados da população.

Os principais problemas ambientais e os potenciais impactos da ação estratégica são definidos também nesta fase, a partir de seus objetivos e metas traçados. Os indicadores ambientais devem ser definidos para a coleta de dados e os padrões de qualidade ambiental são identificados. No entanto, sendo a AAE um processo contínuo, os resultados obtidos com 
as avaliações posteriores, incluindo o monitoramento ambiental, podem conduzir à reformulação dos objetivos e a utilização de outros indicadores ambientais apropriados aos acontecimentos futuros (THERIVEL, 2004; UNITED NATIONS ENVIRONMENTAL PROGRAMME, 2004).

Outras ações estratégicas relacionadas também necessitam ser identificadas nesta fase, a fim de conciliar seus objetivos e metas, evitando conflitos entre as propostas. Políticas, legislações, Planos e Programas que influenciam na estratégia em análise. A coordenação institucional é imprescindível para que este fato se efetive, o que é muito difícil de ocorrer em função da compartimentalização das funções do Estado (UNITED NATIONS ENVIRONMENTAL PROGRAMME, 2004). Como metodologia que possa auxiliar esta etapa, Therivel (2004) cita as matrizes de compatibilidade. Esta autora demonstra alguns tipos de conflitos existentes entre ações estratégicas, quais sejam:

-ações estratégicas hierarquicamente inferiores que necessitam ser elaboradas anteriormente às de nível superior como, por exemplo, planos de defesa contra enchentes os quais, por seu caráter de urgência, necessitam ser criados antes que ações em larga escala, como planos de manejo de águas preventivos sejam elaborados;

- ações estratégicas de níveis superiores que conflitam com as de nível hierárquico inferiores, como políticas ou planos nacionais ou estaduais de construção de moradias ou de aeroportos que possam contradizer aos planos de uso do solo de uma determinada localidade;

- conflitos entre ações estratégicas de mesmo nível hierárquico;

- sobreposição de estratégias que possam ter seus objetivos duplicados;

- estratégias que possam ser afetadas por atividades econômicas, como uma política de transporte dificultada por planos de companhias de transporte urbano.

Tais conflitos se dão pela ausência de etapas claras de planejamento, que deveriam ocorrer no sentido hierárquico, desde as Políticas e legislações em níveis superiores aos Planos, Programas e Projetos, em uma abordagem de planejamento top down, ou seja, de cima para baixo ou "em cascata", prática não adotada geralmente na maior parte dos países. Além disto, como anteriormente exposto, há o problema da ausência de coordenação institucional e de participação social nas tomadas de decisão (THERIVEL, 2004).

\section{- Base ambiental}

Esta etapa se propõe, assim como nos EIAs, ao levantamento de informações ambientais relevantes para a posterior identificação e avaliação dos potenciais impactos. No 
entanto, diferentemente do EIA, o recorte territorial da AAE é mais amplo e menos detalhado (THERIVEL, 2004). Tal autora define a base ambiental como "[...] o estado atual do ambiente e seu provável futuro na ausência da ação estratégica", utilizando indicadores ambientais como ferramentas (THERIVEL, 2004, p.92). Para tanto, os seguintes dados e documentos podem ser necessários para a coleta (EGLER; FILHO, 2004):

- relatórios ambientais em âmbito nacional, regional e municipal, de acordo com os propósitos da estratégia;

- PPPs existentes na área de influência direta e indireta da ação estratégica;

- projetos implantados na área territorial de influência da estratégia;

- EIAs e auditorias ambientais realizados no território abrangido pela AAE;

- Agendas ambientais da localidade com seus objetivos e indicadores ambientais;

A estes, podem ser somados os Planos Diretores municipais, os Planos de Bacias Hidrográficas, zoneamentos ambientais, parâmetros e limites de emissão de poluentes em âmbito nacional, estadual e/ou municipal, consultas à população interessada, sendo os dados de natureza qualitativa e quantitativa. Dados ambientais sobre a hidrologia, topografia, solo, áreas especialmente protegidas, estrutura da paisagem, área urbana consolidada, etc, podem ser levantados para compor o diagnóstico ambiental por meio de sistemas de informações geográficas. Torna-se importante definir a abrangência do recorte territorial para a coleta das informações necessárias (THERIVEL, 2004).

Therivel (2004) ressalta a importância dos limites de qualidade ambiental e seus níveis desejados para a identificação dos problemas ambientais correntes. Entretanto, ressalta o fato de que muitas vezes, inexistem informações a respeito do estado atual de qualidade ambiental, dificultando a identificação de possíveis problemas. A importância da participação pública é importante neste sentido, pois o conhecimento acerca destes problemas pode ser identificado pelas comunidades locais, assim como permite que os atores sociais afetados pela estratégia explicitem as questões ambientais que caracterizam como sendo importantes.

A AAE utiliza temas abrangentes ou objetivos que necessitam de dados ambientais e indicadores para a descrição, o diagnóstico e o monitoramento ambientais, de acordo com os objetivos e metas da ação estratégica, que são definidos na etapa anterior de escopo. É fundamental que dados ambientais não sejam coletados desnecessariamente, visando dinamizar a avaliação e evitar custos e tempo indevidos. No entanto, assim como ocorre freqüentemente nos EIAs, as informações indispensáveis podem não estar presentes, de fácil acesso, encontrar-se ultrapassadas temporalmente e, mesmo quando presentes, podem estar em escalas inadequadas, geralmente refletindo o espaço territorial nacional ou estadual 
(THERIVEL, 2004). Tal autora ressalta que a coleta de dados deve assumir um aspecto de retroalimentação, auxiliando na redefinição dos objetivos e dos indicadores da ação estratégica. O monitoramento ambiental também pode indicar a necessidade de coleta de novas informações, já que não se pode assumir que as condições ambientais existentes permanecerão iguais no futuro, em função da dinâmica ambiental na ausência ou presença da estratégia em questão.

No Brasil, um instrumento da Política Nacional do Meio Ambiente trata justamente da coleta e disponibilização de informações ambientais a ser realizada pelo Poder Público. No entanto, até o momento, esta ferramenta fundamental para todas as etapas da AIA não se encontra regulamentada no país, cabendo diversas vezes às instituições acadêmicas sua realização. Além dos dados brutos coletados, importantes para a proposta em questão, é necessário que tais informações sejam analisadas espacialmente, podendo-se utilizar ferramentas que espacializem estas informações, tais como os Sistemas de Informações Geográficas. A partir da sobreposição de mapas temáticos, tais como tipos de solo, águas superficiais, cálculos de relevo, áreas de conservação, malha urbana, dentre outros que sejam necessários, pode-se, por meio da ponderação em grau de importância dos fatores ambientais levantados, indicarem espacialmente as áreas que possuem maior fragilidade, ou seja, mais adequadas à implantação da proposta. Estas informações espacializadas, que constituem no diagnóstico ambiental, subsidiam o levantamento de alternativas locacionais e a previsão e avaliação de seus respectivos impactos ambientais, além de seu posterior monitoramento. Alternativas tecnológicas também podem ser identificadas na medida em que os fatores mais sensíveis do meio aos impactos potencialmente negativos possam conduzir à medidas mitigadoras (SOUZA, 2007).

\section{* Levantamento de alternativas}

Alternativas são opções para a execução de objetivos estratégicos, constituindo-se em meios para alcançar os propósitos fundamentais da AAE, que seriam garantir um elevado nível de proteção ambiental inserindo esta variável nos processos de tomadas de decisão (DESMOND, 2007). O levantamento de alternativas de desenvolvimento, tecnológicas e locacionais é consideravelmente mais abrangente na AAE do que no EIA, quando o projeto, etapa final na hierarquia do planejamento, já se encontra definido. A partir dos objetivos estratégicos, buscam-se as possíveis alternativas que os alcancem, incluindo a opção de não prosseguir com a ação. Na existência de uma ampla gama de alternativas, algumas 
metodologias podem auxiliar em sua escolha, tais como a análise multicritério e de custosbenefícios, sendo a participação pública muito importante nesta etapa (UNITED NATIONS ENVIRONMENTAL PROGRAMME, 2004).

A AAE permite que o planejamento ambiental ocorra de maneira pró-ativa, ao invés da forma reativa que se dá pelo EIA, de acordo com uma visão de futuro democraticamente construída, já que envolve decisões de cunho político. Segundo Therivel (2004):

O papel da AAE é auxiliar na identificação de alternativas de longo prazo e mais sustentáveis, identificar e avaliar os impactos ambientais das diversas alternativas para informar e dar suporte à escolha das alternativas e esperar que se tome a decisão mais sustentável; e ajudar a documentar como a(s) alternativa(s) preferida(s) foi(foram) escolhida(s), de modo a realizar uma tomada de decisão mais transparente e inclusiva.

(THERIVEL, 2004, p.110)

Therivel (2004) apresenta uma metodologia para o levantamento e escolha de alternativas, por meio dos seguintes passos:

1. Questionar a importância da ação estratégica, ou seja, se é necessária. Uma pergunta a ser feita seria se a demanda da sociedade ou governo/companhias privadas poderia ser satisfeita sem a necessidade de novo desenvolvimento. Por exemplo, ao invés de se optar por construir novas usinas hidreelétricas, uma possível alternativa seria a minimização do consumo de energia.

2. Levantar alternativas tecnológicas e metodológicas que possibilitem alcançar as finalidades da estratégia com alterações ambientais mínimas, ao invés de se proceder com as técnicas comumente utilizadas, permitindo a inovação tecnológica.

3. Abarcar todas as alternativas locacionais possíveis, menos impactantes do ponto de vista ambiental, social e econômico.

4. Determinar quando e em qual sequiência o desenvolvimento será realizado e os requerimentos para sua implementação.

Segundo esta autora, as alternativas mais estratégicas, que envolvem as etapas de redução ou necessidade das demandas e modelos de desenvolvimento (etapas 1 e 2 acima apresentadas) são mais adequadas para o âmbito de políticas, enquanto que as alternativas que exigem maior nível de detalhamento, tais como a localização e implementação da estratégia (etapas 3 e 4) são melhor aplicáveis no âmbito de programas e projetos.

Dentre as alternativas levantadas, a não consecução da ação estratégica deve ser considerada, o que implica questionar a necessidade de implantá-la. Therivel (2004) propõe a 
realização de uma AAE das estratégias correlacionadas existentes, caso as haja, a fim de se identificar se novas abordagens às demandas são realmente indispensáveis. A otimização do uso dos recursos naturais sempre é considerada pela autora como uma forma de evitar que novos desenvolvimentos sejam realizados desnecessariamente e, quando tal solução não resolva o problema da demanda, a AAE deve possibilitar a escolha da melhor alternativa possível do ponto de vista ambiental, considerando que todas as propostas de desenvolvimento sejam potencialmente impactantes.

Em algumas situações, no entanto, a opção pelo não desenvolvimento pode ser menos sustentável do que sua execução como, por exemplo, a construção de moradias em locais com infra-estrutura urbana consolidada ao invés de instalar residências em outras localidades que demandem por novas infra-estruturas. Além disto, as alternativas e opções levantadas devem ser praticáveis e racionais, eliminando-se aquelas irrealizáveis do ponto de vista lógico e legal, mas sempre justificando as razões para tanto no relatório da AAE (THERIVEL, 2004).

Outra metodologia para a consideração de alternativas em AAE é apresentada por Desmond (2007), que se inicia com a descrição das etapas de elaboração da ação estratégica. A racionalidade nas tomadas de decisões estratégicas se reflete em procedimentos organizados envolvendo a participação de múltiplos atores sociais, a definição de objetivos e métodos de análise de performance, a identificação e avaliação de alternativas possíveis e a consideração das interações e incertezas existentes. Para a análise e escolha das alternativas, a combinação de técnicas de multi-objetivos e multi-atributos demonstram-se adequadas, por considerar os componentes dos objetivos e atributos da ação planejada (HENIG; BUCHANAN, 1996 apud DESMOND, 2007). Tal fato decorre de o planejamento conter objetivos e sub-objetivos e atributos que avaliem a performance das alternativas em atendêlos.

\section{* Previsão, avaliação e mitigação de impactos ambientais}

Segundo Therivel (2004), tal etapa é a que consome mais tempo e recursos financeiros na AAE, envolvendo diversos estágios durante o planejamento, avaliando as alternativas elaboradas e escolhidas em cada momento decisório e a elaboração do plano de mitigação dos potenciais impactos ambientais da estratégia. Uma das vantagens da AAE em detrimento do EIA é a previsão e avaliação de impactos indiretos e cumulativos, muito 
difíceis de serem cobertos no âmbito de projetos (EGLER; FILHO, 2004).

A previsão dos impactos envolve a determinação da escala, duração, probabilidade e magnitude dos impactos potenciais, uma etapa que depende essencialmente do julgamento de seus participantes, enquanto a mitigação constitui-se na minimização dos impactos negativos e maximização dos impactos positivos da estratégia. Segundo Therivel (2004, p. 135), "o impacto da ação estratégica é a diferença entre as condições ambientais/de sustentabilidade com ou sem a ação estratégica", e envolve os seguintes estágios:

- prever como será a ação estratégica como, por exemplo, quais atividades provavelmente serão geradas, em qual local e quando este fato ocorrerá;

- para cada indicador ambiental ou de sustentabilidade analisado, determinar a área geográfica e o horizonte temporal em que a previsão será contemplada;

- prever quais as possíveis alterações na base ambiental derivadas pelas diversas alternativas levantadas pela ação estratégica;

- analisar os impactos de acordo com sua natureza: positivos ou negativos, sua magnitude, distribuição espacial, duração, se são reversíveis ou irreversíveis e a probabilidade de ocorrência.

A AAE lida com impactos em amplas áreas geográficas, em que estão ou serão implantados um grande número de projetos e que, portanto, abrem um grande leque de alternativas e opções para implementar os objetivos das diretrizes formuladas pelas PPPs relativas a estas localizações. Não há uma metodologia única e ótima para a previsão e avaliação dos impactos das alternativas propostas, já que o diagnóstico ambiental não oferece um nível elevado de detalhamento, somente possibilitado, caso existam estas informações, na consecução dos EIAs, sendo o grau de incertezas nas previsões bastante alto.

Além disto, as dificuldades de integração institucional por meio de canais de comunicação adequados são muito complexas, principalmente em países em que as políticas territoriais são amplamente setorizadas e não há tradição de planejamento em longo prazo (ORGANIZATION FOR ECONOMIC COOPERATION AND DEVELOPMENT, 2006).

Algumas das metodologias utilizadas em AAE, principalmente no âmbito de Planos e Programas derivam das práticas do EIA, tais como matrizes, redes de interação, cenarização, análise custo-benefício, análise multicritério, dentre outras, as quais se beneficiam muito dos sistemas de infomações geográficas, que possibilitam um diagnóstico ambiental espacializado. As técnicas de cenários, listagem de controle, custo-benefício e multicriterial são utilizadas preferencialmente em situações de grandes incertezas envolvendo unidades territoriais extensas, como país, estado, biomas, regiões, enquanto que as matrizes e redes de 
interação são mais propícias a exames com maior nível de detalhamento espacial (PARTIDÁRIO, 2002).

Ao contrário do EIA, instrumento que, como visto, não permite análise de alternativas locacionais e de desenvolvimento e, quando muito, tecnológicas e operacionais, a AAE possibilita em maior grau a prevenção dos potenciais impactos ambientais ao invés de sua mitigação. No entanto, é inevitável o surgimento de impactos imprevistos e mesmo previstos, decorrentes de qualquer modelo de desenvolvimento escolhido, levando à necessidade de sua mitigação.

Uma hierarquia de ações preventivas e corretivas para lidar com os potenciais impactos negativos pode ser estabelecida em AAE, no sentido de inicialmente evitar os impactos (prevenção), reluzi-los e, finalmente, corrigi-los, dando ênfase em evitar aqueles que sejam considerados de maior risco, de grande significância e irreversíveis. Quando ações mitigadoras são praticadas, torna-se importante considerar os possíveis impactos residuais, avaliados segundo os objetivos e critérios ambientais almejados (ORGANIZATION FOR ECONOMIC COOPERATION AND DEVELOPMENT, 2006).

\section{* Relatório}

Após realizada as etapas anteriores, é aconselhável em um sistema de AAE que se faça um relatório contendo, resumidamente, os propósitos de sua realização, as metas e indicadores utilizadas para a análise, as alternativas levantadas e a análise e predição de seus impactos com as metodologias utilizadas, as justificativas para a escolha das alternativas, o plano de monitoramento, as formas e momentos de participação social e demais atividades realizadas durante a AAE, sendo submetido ao escrutínio público. Tal etapa é importante não somente para informar os tomadores de decisão e justificar as opções realizadas, mas também para submeter a AAE a uma revisão por agentes independentes, garantindo sua legitimidade e qualidade. O público interessado e diretamente afetado pela ação estratégica deve participar desta revisão por meio de audiências, entrevistas e outros métodos, possibilitando que influencie as decisões tomadas (ORGANIZATION FOR ECONOMIC COOPERATION AND DEVELOPMENT, 2006).

\section{Monitoramento}

O monitoramento ambiental é uma das etapas mais cruciais da AAE e que a 
diferencia dos estudos pontuais realizados para atividades (EIA), já que se constitui em um processo contínuo, não finalizado após a implementação de PPPs (HANUSCH; GLASSON, 2008). A partir das metas, critérios e indicadores selecionados, o estado do meio ambiente (entendido como biofísico ou "natural" e antrópico, envolvendo aspectos sociais, econômicos e culturais) é monitorado com o objetivo de se detectar a ocorrência dos impactos previstos ou imprevistos, além da efetivação dos objetivos propostos pela estratégia.

A Diretiva Européia sobre AAE requer, em seu artigo $10^{\circ}$, que os países-membro monitorem os impactos ambientais significativos das PPPs implantadas a fim de identificar potenciais efeitos negativos previstos ou não e tomar as medidas mitigadoras necessárias (HANUSCH; GLASSON, 2008). Segundo estes autores, o monitoramento em AAE possibilita o entendimento sobre o processo de planejamento, com uma perspectiva cíclica e não-linear.

Os indicadores a serem monitorados são inicialmente definidos na fase de escopo da AAE, a partir dos objetivos da ação proposta e da previsão dos impactos significativos (HANUSCH; GLASSON, 2008). O monitoramento permite o constante aprendizado dos mecanismos que permeiam a realização da Política, Plano ou Programa em questão, aprimorando-os e, se necessário, adaptando-os tendo em vista a melhoria da qualidade ambiental (por meio da identificação do estado do meio ambiente com a implantação da estratégia). Deste modo, a realização dos objetivos da AAE é possibilitada em um horizonte temporal amplo, auxiliando na realização de outras PPPs relacionadas e nas ações estratégicas hierarquicamente inferiores, culminando nos potenciais projetos (HANUSCH; GLASSON, 2008).

As informações adquiridas nesta fase contínua, assim como nas demais em AAE, devem ser disponibilizadas ao público interessado, tanto para o conhecimento do andamento da proposta estratégica quanto para possíveis intervenções (PARTIDÁRIO, 2002; ORGANIZATION FOR ECONOMIC COOPERATION AND DEVELOPMENT, 2006).

Tendo em vista os critérios necessários à avaliação de impactos ambientais de ações estratégicas e pontuais considerados anteriormente, a tabela 46 ilustra as diferentes características dos instrumentos considerados no presente trabalho, quais sejam, a Análise de Risco, o EIA e a AAE: 
Tabela 46 - Comparação entre Análise de Risco, Estudo de Impacto Ambiental e Avaliação Ambiental Estratégica em função de critérios necessários à avaliação de impactos ambientais.

\begin{tabular}{|c|c|c|c|}
\hline Parâmetros & $\mathbf{A R}$ & EIA & AAE \\
\hline $\begin{array}{l}\text { Ligação com outras } \\
\text { PPPs. }\end{array}$ & Não. & $\begin{array}{l}\text { Na prática não, pois } \\
\text { realiza uma avaliação } \\
\text { pontual. }\end{array}$ & Sim. \\
\hline $\begin{array}{l}\text { Avaliação de impactos } \\
\text { cumulativos e indiretos }\end{array}$ & Não. & Não. & Sim. \\
\hline $\begin{array}{ll}\text { Recortes } & \text { territoriais } \\
\text { analisados. } & \end{array}$ & Reduzido. & $\begin{array}{c}\text { Reduzidos (âmbito do } \\
\text { projeto). }\end{array}$ & $\begin{array}{l}\text { Amplas áreas } \\
\text { geográficas. }\end{array}$ \\
\hline Função do instrumento. & $\begin{array}{l}\text { Instrumento pontual, } \\
\text { que prevê potenciais } \\
\text { danos. }\end{array}$ & $\begin{array}{l}\text { Instrumento de } \\
\text { licenciamento } \\
\text { ambiental. }\end{array}$ & $\begin{array}{l}\text { Instrumento de } \\
\text { planejamento } \\
\text { ambiental. }\end{array}$ \\
\hline $\begin{array}{l}\text { Possibilita análise de } \\
\text { alternativas: } \\
\text { - De modelos de } \\
\text { desenvolvimento; } \\
\text { - Locacionais; } \\
\text { - Tecnológicas. }\end{array}$ & Não. & $\begin{array}{l}\text { Alternativas restritas } \\
\text { ao projeto: } \\
\text { - Tecnológicas; } \\
\text { - Operacionais. }\end{array}$ & $\begin{array}{l}\text { Sim, especialmente } \\
\text { alternativas de } \\
\text { desenvolvimento e } \\
\text { locacionais. }\end{array}$ \\
\hline 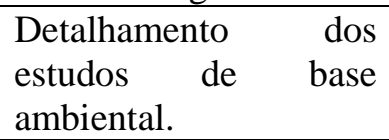 & Maior detalhamento. & Maior detalhamento. & Menor detalhamento. \\
\hline Participação social. & $\begin{array}{l}\text { Pouca ou nula. } \\
\text { Domínio de } \\
\text { especialistas. }\end{array}$ & $\begin{array}{c}\text { Somente nas } \\
\text { audiências públicas. }\end{array}$ & $\begin{array}{l}\text { Sim, teoricamente em } \\
\text { todas as etapas. }\end{array}$ \\
\hline $\begin{array}{l}\text { Monitoramento } \\
\text { ambiental. }\end{array}$ & Não. & Curto período. & Contínuo. \\
\hline
\end{tabular}

\section{Experiências de utilização da AAE para avaliação de impactos ambientais de OGMs.}

Em relação aos OGMs, encontrou-se na presente revisão bibliográfica realizada, apenas dois casos de proposição do uso de AAE para a biotecnologia de aplicação agrícola. Um deles foi desenvolvido por Linacre et al. (2005) por meio do International Food Policy Research Institute em Washington (EUA), tendo em vista a elaboração de metodologia para a avaliação de pesquisas direcionadas aos OGMs. Na proposta realizada, considerou-se o instrumento AAE importante para o planejamento das pesquisas incorporando-se questões socioambientais em seu delineamento, assim como a participação pública nos processos decisórios.

A metodologia teve como base análises de risco utilizando dados quantitativos e qualitativos, perante participação pública. Durante a avaliação qualitativa, os proponentes identificam os planos e programas relacionados ao tema, realizam consultas a especialistas e 
demais interessados para a delimitação dos objetivos, das alternativas tecnológicas para seu alcance e os impactos ambientais derivados das mesmas. Técnicas de análise multicritério podem ser empregadas neste momento, buscando-se uma decisão consensual (LINACRE et al.,2005).

Dentre os dados quantitativos requeridos encontram-se: a biologia e ecologia do cultivo em questão, o produto gênico da transgenia, as mudanças potenciais aos usos do solo, dentre outras, que sejam importantes para a avaliação da capacidade de escape gênico, invasão e toxicidade do OGM. A análise de risco é empregada, com a determinação da probabilidade de ocorrência e magnitude dos riscos, considerando o grau de incerteza. Desta forma, estabelece-se a gestão dos riscos, optando-se pelas seguintes decisões: aceitar os riscos reconhecendo seu custo-benefício, manejá-los, por meio de estratégias de prevenção e mitigação (uso do OGM em contenção, estabelecimento de distâncias mínimas entre cultivos, segregação ao longo da cadeia produtiva, monitoramento) ou evitá-los com a não realização da atividade. Um esquema com a metodologia desenvolvida pode ser observado na Figura 9 (LINACRE et al, 2005).

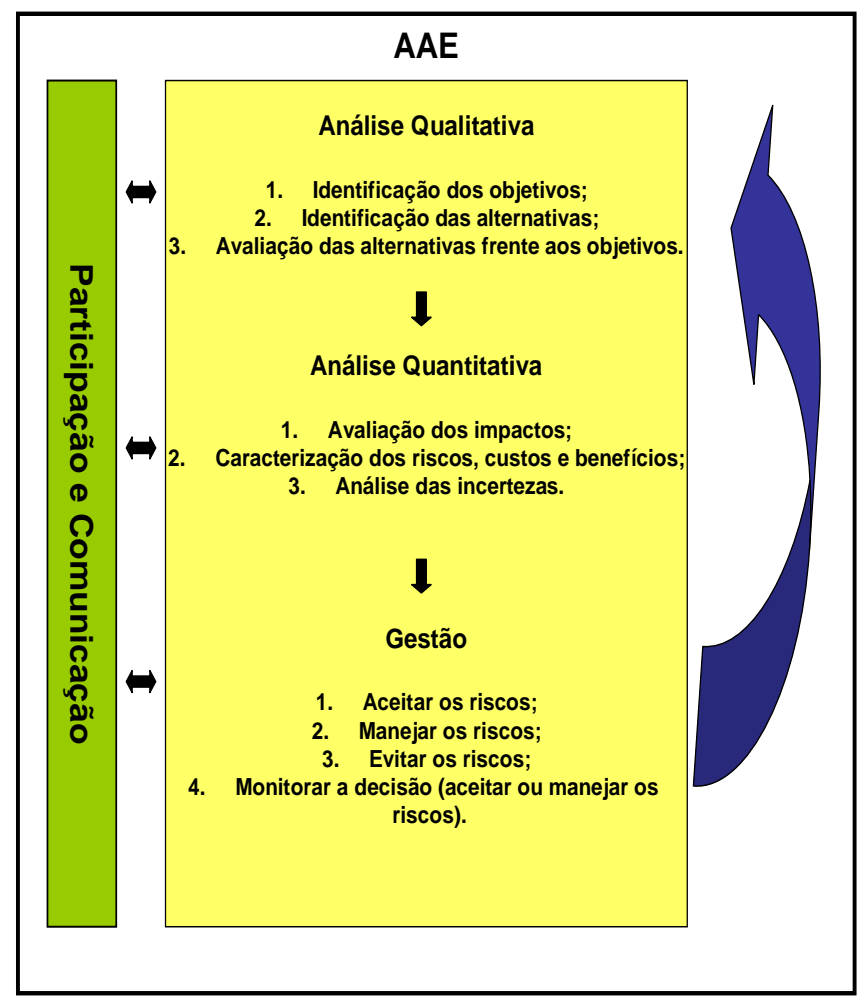

Figura 9 - Metodologia para Avaliação Ambiental Estratégica de pesquisas sobre OGMs. Fonte: Modificado de Linacre et al. (2005) 
Outro trabalho encontrado foi a tese de doutorado de Pessôa (2007), que propôs uma metodologia de AAE baseada em cenários ambientais e sócio-econômicos futuros a partir da definição de indicadores de Pressão, Estado, Impacto e Resposta. A metodologia baseou-se em avaliações dos impactos ambientais, econômicos e de saúde, resultando em cenários favoráveis ao uso da tecnologia.

No entanto, diferentemente do presente estudo, a autora considerou que a participação nas tomadas de decisão na $\mathrm{AAE}$ seja restringida a especialistas no assunto e tratou especificamente de uma metodologia de avaliação de impactos da tecnologia, ou seja, um dos passos da AAE. Do mesmo modo, o objetivo do trabalho de Linacre et al. (2005) diferenciase deste trabalho, já que se trata de pesquisas com OGMs.

\subsection{Os instrumentos de estudos ambientais e suas potencialidades e fragilidades para a liberação de PGMs em escala comercial.}

\subsubsection{Análise de risco}

Snow et al. (2005) e Stirling (1999) levantam algumas fragilidades do instrumento análise de risco como única forma de se avaliar os potenciais impactos dos OGMs para o meio ambiente, saúde humana e demais animais. Tais análises, em sua maioria, são realizadas em pequena escala, com os organismos em contenção, utilizando-se técnicas de manejo agrícola que dificilmente são condicionantes para a liberação comercial. Segundo estes autores, as análises realizadas em pequena escala são passíveis de identificar a magnitude dos impactos, enquanto que possíveis consequências danosas devidas à variabilidade de interações ecossistêmicas no ambiente de liberação são difíceis de prever.

Para Andow e Hilbeck (2004), a utilização da AR para deliberações acerca do uso de OGMs se dá em função da credibilidade científica do método, que implica em resultados precisos. No entanto, por experiência, os riscos ambientais apenas são detectados após a ocorrência dos danos, o que impossibilita o uso do instrumento para a tomada de decisões prévias. Para exemplificar, os autores citam os impactos ocasionados pela introdução de espécies exóticas, a qual não era avaliada como uma atividade perigosa até que seus danos fossem evidenciados. Mesmo atualmente, os riscos da introdução de espécies exóticas são desconhecidos, por conta da falta de conhecimento sobre as relações ecológicas nos locais de introdução destes organismos, conduzindo ao aumento das incertezas e na imprecisão da AR. 
Algumas dificuldades em se conduzir uma análise de risco pré-comercial no tocante aos OGMs serão abordadas a seguir.

Apesar do princípio de cientificidade defendido como inerente à análise de risco, em função de seu aspecto técnico, a falta de informações sobre os potenciais efeitos ambientais e à saúde ocasionados pelos OGMs ainda não se encontram elucidados, apesar dos esforços das instituições de pesquisa neste sentido. Além disto, a ausência de protocolos, tanto internacionais como nacionais, cientificamente embasados para o tratamento das incertezas é uma barreira para uma AR eficiente (MYHR; TRAAVIK, 2001; MEEK; KEESE, sem data). A justificativa para tanto se dá em parte pelo curto período de experiência com pesquisas laboratoriais e em campo com tais organismos, que ainda não somam duas décadas. Estudos de longo prazo, com exceção do Farm Scale Evaluation, desenvolvido no Reino Unido em um período de quatro anos, não são elaborados previamente à liberação ambiental de OGMs e a literatura científica vem se baseando apenas em hipóteses, muitas das quais prevêem potenciais efeitos adversos e até mesmo irreversíveis (MYHR; TRAAVIK, 2001).

De acordo com Giampietro (2002), no momento em que surgem novas situações ou tecnologias, não é adequado ater-se a estimativas probabilísticas, utilizadas pelos especialistas a fim de comprovar que um determinado risco seja ou não negligenciável. Segundo o autor, a avaliação numérica dos riscos assume que um problema conhecido será futuramente válido.

Argumentos acerca da ausência de provas a respeito dos impactos negativos ocasionados por OGMs são frequentemente utilizados pelos defensores da tecnologia. Entretanto, de acordo com o princípio da precaução, a ausência de provas não pode ser interpretada como prova da ausência de danos potenciais. Para justificar a inocuidade dos OGMs, emprega-se o princípio da equivalência substancial destes com suas contrapartes convencionais, em termos de composição química (como nível de carboidratos, gorduras, proteínas, dentre outros). Uma ampla controvérsia quanto à utilização deste princípio se dá pela ausência de limites quanto ao nível destas substâncias que possam comprovar a igualdade entre ambas as variedades, transgênica e convencional. Tal fator é considerado por diversos atores participantes neste debate como anti-científico, inviabilizando a análise dos riscos e outros instrumentos de avaliação de impactos (MILLSTONE; BRUNNER; MAYER, 1999).

A utilização do princípio da equivalência substancial impossibilita que qualquer tipo de avaliação ambiental de OGMs se dê de forma cientificamente embasada, e que as incertezas inerentes à análise de risco sejam consideradas. Segundo Millstone, Brunner e Mayer (1999, p.526): 
A equivalência substancial é um conceito pseudo-científico porque é um julgamento comercial e político mascarado de científico. Ele é, além disso, inerentemente anti-científico, porque foi criado primeiramente para fornecer uma desculpa para não se requerer testes bioquímicos e toxicológicos. Ele ainda serve para desencorajar e inibir pesquisas científicas potencialmente informativas.

As leis de propriedade intelectual intensificam tal impasse, na medida em que informações fundamentais para a compreensão dos riscos expostos à coletividade e ao meio ambiente com a liberação de OGMs sem a consideração de seus riscos potenciais são dificultadas pelo sigilo comercial, aceito pelas autoridades competentes por grande parte das nações que possuem regulamentações acerca de OGMs (MYHR; TRAAVIK, 2001).

Para Giampietro (2002), diferentemente da análise de risco de substâncias perigosas, tais como elementos radioativos, que possuem uma meia-vida determinada e de acidentes industriais, para os quais medidas de segurança podem ser tomadas a fim de prevenir a cadeia de eventos que resultem em danos, os OGMs, por serem organismos que têm a capacidade de se auto-reproduzir, disseminar e persistir no ambiente, possuem riscos difíceis de serem previstos. O autor exemplifica o caso da doença da "vaca louca" (encefalopatite espongiforme bovina), que teve seu surgimento após a adição de proteína animal em sua dieta com intuito de aumentar a produtividade da carne de origem bovina. Naquele momento, não se poderia prever o desenvolvimento de uma doença neuronal desencadeada pela alimentação e qualquer análise de risco se demonstraria como inadequada, em função da imprevisibilidade de suas consequências.

No caso dos OGMs, as incertezas quanto à sua segurança alimentar e ambiental se dão nos seguintes aspectos:

A metodologia de inserção do transgene, que é um assunto bastante contraditório. Embora as empresas de biotecnologia e diversos cientistas que trabalham nesta área afirmem que os insertos se alojam nas regiões esperadas do genoma receptor, outros cientistas se contrapõem a tal idéia, alegando que os métodos empregados (geralmente por biobalística) não permitem afirmar com certeza o local de inserção de transgene. O mesmo se dá com o número de cópias do inserto. Alguns estudos demonstram inserções dos transgenes em locais de instabilidade genética e a existência de diversas cópias do inserto no genoma receptor. Deste modo, a instabilidade genética, o silenciamento ou ativação de genes não-alvo podem resultar em consequências danosas, tais como: potencial aumentado de fluxo gênico, produção de substâncias tóxicas ou alergênicas, superexpressão da proteína desejada, dentre outros 
(FINNEGAN; MCELROY, 1994; HO; CHING, 2003; HO; CUMMINS; RIAN, 2002 apud LIMA, 2007);

A premissa de que um gene conduz à produção de uma única proteína tem sido contestada pelas evidências da epigenética, que discorre sobre a importância dos fatores ambientais na expressão gênica. Deste modo, indivíduos que compartilham o mesmo genótipo podem apresentar fenótipos diferentes de acordo com as interações ambientais (GARCIA, 2005). Ao utilizar a proteína isolada nos testes de toxicidade e alergenicidade em laboratório, ao invés do alimento completo propriamente dito, as incertezas quanto à segurança alimentar do OGM não podem ser clarificadas. O mesmo se sucede para a segurança ambiental, já que não se realizam estudos de longo prazo nos locais de liberação do OGM;

As análises de risco não são realizadas em uma perspectiva de longo prazo e a ausência de monitoramento em diversas nações que vêm realizando liberações em larga escala não possibilitam que as incertezas sejam analisadas. Impactos de diversos graus sobre a flora, o solo, a resistência das pragas e das ervas invasoras aos agroquímicos, as alterações nas teias alimentares, dentre outros danos ambientais indiretos e cumulativos podem não ser previstos, o que dificulta a tomada de decisões baseada em custos-benefícios (LIMA, 2007).

Conner, Glare e Nap (2003) discorrem sobre o grau de aceitação e tolerância dos riscos, que não podem ser definidos somente por uma equipe técnica, pois as percepções dos especialistas muitas vezes divergem do público. A escolha da aceitabilidade dos riscos deve considerar questões de cunho político, social, cultural e econômico. Nas discussões sobre os riscos de OGMs, por exemplo, as opiniões diferem inclusive entre especialistas, demonstrando que os valores individuais são tão importantes quanto o conhecimento especializado, fato que afeta a confiança da população a este respeito (SLOVIC, 1999 apud CONNER; GLARE; NAP, 2003).

Para Hansen (2004), a participação dos atores sociais afetados no processo de avaliação de impactos ambientais e na comunicação dos riscos é crucial para a adoção do Princípio da Precaução nestes casos, pois, em situações em que as incertezas superem as evidências quanto à segurança do OGM, a ausência de transparência em sua clarificação nas análises ambientais e de saúde são empecilhos à tomada de decisões. Entretanto, segundo Mayer e Starling (2001), em se tratando da análise de riscos comumente utilizadas para OGMs, a "ignorância e as incertezas são pobremente consideradas, julgamentos políticos e sociais complexos são realizados por especialistas de forma não transparente, e há poucas oportunidades para a participação pública", contrariando o princípio da precaução. 
Stirling (1999) também discorre sobre a subjetividade na formulação das premissas adotadas nas análises de risco, que se baseiam essencialmente em valores dados pelos analistas, daí a necessidade da participação social em todas as suas etapas e a flexibilidade na gestão dos riscos, permitindo um mecanismo de retroalimentação na regulamentação das tecnologias avaliadas.

Durante a Conferência do Rio de Janeiro em 1992, que resultou na Declaração do Rio, o Princípio da Precaução foi consolidado como base orientadora da gestão ambiental nos casos de incerteza científica a respeito de ações potencialmente impactantes, em que os danos ocasionados possam ser sérios ou mesmo irreversíveis. Todavia, a ausência de delimitação para os termos "danos", “impactos significativos", “irreversíveis", “custo-benefício" e até mesmo a definição e limites para o que se considera como incerteza, dificulta a aplicação deste princípio nas políticas governamentais (VAN DEN BELT; GREMMEN, 2001; GIAMPIETRO, 2002). Dado a interpretações subjetivas, cabe aos governos, em conjunto com a sociedade, definir em que momentos utilizar este princípio, sendo uma decisão estritamente política, já que envolve conflitos de interesses.

Bruce (2001) levanta o aspecto tradicional da análise de risco que considera o desenvolvimento tecnológico como um bem em si e que traz benefícios sociais e econômicos para a sociedade, como empregos e melhoria na qualidade de vida, em uma percepção progressista da Ciência. Deste modo, os benefícios concedidos à maioria da sociedade, sempre na forma de desenvolvimento econômico, justificam os danos potenciais conferidos a uma minoria e ao meio ambiente. Neste sentido, Busch (2001) destaca a visão progressista comumente adotada de que os erros podem ser solucionados pelo desenvolvimento de novas tecnologias, minando atitudes precaucionistas. Para este autor, as experiências passadas demonstram que o desenvolvimento tecnológico nem sempre pode resultar em benefícios e que não existem certezas sobre suas consequências. O princípio da precaução baseia-se em uma análise de longo prazo, contrapondo a filosofia utilitarista de curto prazo, e na proteção dos direitos das populações mais desfavorecidas, que muitas vezes sofrem os maiores danos com os impactos ambientais derivados de certas opções tecnológicas. Neste sentido, a precaução é uma opção política com vistas a antecipar e evitar os riscos ao invés de ser reativa, quando não houver provas suficientes para identificá-los e avaliá-los.

No entanto, há controvérsias sobre a implementação da precaução na análise de risco e na tomada de decisões sobre OGMs, já que diversos cientistas apregoam as dificuldades de se estabelecer relações de causa-efeito quanto aos potenciais riscos deles derivados, tornando complicada a previsão sobre os danos que possam se suceder. Teme-se, deste modo, que haja 
um cerceamento sobre as pesquisas com OGMs e a consequente ausência de retorno financeiro, sobretudo às empresas que realizam pesquisas na área de biotecnologia, em grande parte alcançada com a aplicação industrial destes organismos (MYHR; TRAAVIK, 2001).

Quanto às tipologias de impactos ambientais consideradas, uma das dificuldades do instrumento é a avaliação dos impactos cumulativos. No tocante ao cultivo em escala comercial de PGMs, Henry (2006, p.6) aborda a potencialidade de ocorrência dos seguintes impactos cumulativos:

[...] efeitos cumulativos de liberações sobre a saúde humana/animal e o meio ambiente, incluindo inter alia flora e fauna, fertilidade do solo, degradação de matéria orgânica no solo, cadeia alimentar, diversidade biológica, saúde animal e problemas de resistência em relação a antibióticos. A disponibilidade de cultivos OGMs podem ocasionar efeitos sobre todos os itens acima devido à modificações amplas na agricultura, uso do solo e sócio-econômicas.

Os efeitos cumulativos podem se dar, segundo a autora, em função da das liberações sucessivas de PGMs ao longo do tempo e em larga escala, sendo sua identificação dependente de programas de monitoramento contínuos. No entanto, a maioria dos países não o estabelece e, quando sim, observa-se uma indefinição dos métodos a serem utilizados.

Segundo Henry (2006), umas das dificuldades das análises de risco para a previsão dos impactos cumulativos e indiretos é sua realização em condições artificiais, em laboratórios ou em campos de contenção, fato que impossibilita a observação das condições ambientais reais presentes quando da liberação em escala comercial do OGM. Além disto, a autora argumenta que um dos maiores desafios para a análise de riscos cumulativos de longo prazo relativos às PGMs é a delimitação da temporalidade dos estudos. Os riscos de impactos tecnológicos, tais como os resíduos de radioatividade são mais conhecidos, em função da meia-vida dos elementos radioativos e dos eventos que podem desencadear os danos (inalação, ingestão, vazamentos), o que é muito diferente no caso de organismos vivos que estão sujeitos às variabilidades nos ambientes de liberação. Nestas análises de risco, as incertezas podem ser consideradas menores devido ao conhecimento, o que possibilita a detecção dos momentos de pico dos riscos e facilita seu controle. Já para as PGMs, quando liberadas, há a possibilidade de os riscos aumentarem se, a título de exemplificação, as espécies modificadas se tornarem invasoras em função de vantagens seletivas. Daí a necessidade de uma análise de longo prazo, considerando mudanças climáticas e de práticas agrícolas. 
Alguns países, como os EUA, Austrália e Nova Zelândia consideram em suas legislações a análise de risco de impactos cumulativos para OGMs, mas essencialmente em relação aos eventos esperados. As ferramentas de análise não possibilitam a avaliação dos efeitos inesperados que possam se dar em longo prazo no caso da liberação em larga escala destes organismos. Na União Européia, considerações são feitas a respeito de possíveis efeitos não antecipados a partir da liberação em larga escala de OGMs, mas não apresenta protocolos ou guias que provenham as questões-chave que necessitam ser levantadas. (HENRY, 2006).

De acordo com Pessôa (2007), o uso da técnica de cenários é propícia para a predição de potenciais impactos considerando horizontes temporais amplos. A avaliação de segurança perante futuros cenários plausíveis podem auxiliar na detecção de riscos em longo prazo, assim como as barreiras para evitá-los, considerando-se sempre as incertezas inerentes.

Em teoria, as análises e gestão de risco para a liberação ambiental de OGMs em diversas nações, nas quais o Brasil se inclui, conforme determinada na Resolução Normativa No.05, de 12 de março de 2008 da CTNBio, necessitam de informações locacionais para a determinação do risco, tais como: a existência de indivíduos da mesma espécie ou parentais no local de liberação, a fim de se evitar o fluxo gênico; o potencial de colonização do OGM, evitando que se torne uma espécie invasora; os impactos sobre organismos não-alvo, sobre a biota do solo e a resistência das espécies alvo aos agroquímicos utilizados. Todos estes aspectos dependem estritamente do local de liberação. No entanto, nos países em que há o cultivo em larga escala de PGMs, tais como EUA, Canadá, Argentina e Brasil, tais análises são realizadas em pequenas áreas sob contenção, prejudicando qualquer tipo de avaliação em situações reais de plantio. No Brasil, os resultados da AR são extrapolados para todo o território nacional e a diversidade de condições ambientais, culturais e econômicas do país não é considerada, impossibilitando a identificação dos potenciais impactos positivos e negativos da liberação da PGM. Tais análises pontuais impossibilitam a avaliação de alternativas locacionais para a liberação das PGMs.

Em alguns países, faz-se apenas uso de recomendações de manejo para que os riscos ambientais sejam reduzidos, tais como a separação entre os sistemas de plantio em campo, rastreamento do OGM ao longo de sua cadeia produtiva, limpeza dos maquinários de uso comum para os diversos sistemas de plantio, assim como nos locais de armazenagem dos produtos, rotulagem e monitoramento pós-comercial. No Brasil, de acordo como o Ministério Público Federal (2007), apenas recomendações relacionadas ao distanciamento de plantios de OGMs adjacentes a espécies aparentadas, nas proximidades de Unidades de Conservação e 
em terras indígenas são exigidas ao proponente e agricultor, mas sem monitoramento e com fiscalização deficiente (MINISTÉRIO PÚBLICO FEDERAL, 2007).

Em relação às alternativas tecnológicas, a $\mathrm{AR}$ não tem em seus procedimentos a análise dos custos-benefícios da tecnologia transgênica frente aos sistemas de plantio alternativos ou convencionais (RAYBOLD, 2007), não possibilitando a ponderação sobre a visão de futuro estabelecida para uma determinada área ou setor, especificada em políticas públicas e, quando existentes, pelos planos e programas que lhes sucedem. Segundo Raybold (2007), a avaliação dos riscos é um subsídio para a tomada de decisões que devem levar em conta suas implicações sociais, econômicas e políticas, as quais possuem uma racionalidade que não a científica.

De acordo com Santos (2004), o planejamento ambiental deve ser uma etapa anterior à avaliação de impactos, justamente para que haja um contexto ambiental que sirva de sustentação à análise, com objetivos e indicadores próprios.

No caso de PGMs a serem liberadas no meio ambiente para uso comercial, ou seja, em larga escala, seria necessário, partindo da necessidade de um planejamento ambiental prévio, a consideração de políticas, planos e programas setoriais e intersetoriais propostos para a unidade territorial em questão, de modo a possibilitar as tomadas de decisão em um horizonte de longo prazo. Tais considerações, no entanto, não são constituintes do instrumento análise de risco.

Deste modo, podem-se citar as seguintes fragilidades da análise de risco como única ferramenta a ser utilizada nos processos decisórios sobre o cultivo em larga escala de PGMs:

- as AR visam à antecipação de eventos/acidentes pontuais e, portanto, não permitem a avaliação sobre os impactos cumulativos e indiretos resultantes da liberação de plantas transgênicas;

- a análise das alternativas locacionais não fazem parte do conteúdo da AR. Já em relação às alternativas tecnológicas, o gerenciamento dos riscos possibilita algumas estratégias que buscam mitigá-los ou mesmo prevení-los. No entanto, não compara os custosbenefícios entre outros sistemas de cultivo, tais como o agroecológico e o convencional;

- a compatibilidade entre as Políticas, Planos e Programas que influenciam na tomada de decisões também não é incumbência da AR;

- o desconhecimento acerca dos mecanismos ambientais de causa e efeito após a introdução da PGM impossibilita o cálculo numérico do risco, comprometendo o método.

Por outro lado, o uso consolidado da Análise de Risco em termos mundiais possibilitou o delineamento dos critérios a serem observados em estudos ambientais relativos 
aos OGMs, tais como o potencial de fluxo gênico de transferência horizontal, de toxicidade e alergenicidade, de impactos sobre organismos não-alvo, dentre outros. Em função disto, a análise de risco pode ser entendida como uma ferramenta que subsidie estudos de impacto ambientais mais aprofundados, estabelecendo os critérios para a ponderação de fatores ambientais a serem considerados em uma avaliação de impactos. A Resolução Normativa No.5, de 12 de março de 2008 da CTNBio fornece uma série de atributos ambientais a serem considerados pelo proponente durante a análise de risco. Entretanto, critérios sócioeconômicos e culturais não se fazem presentes nesta Normativa, apesar de serem necessários para que haja um balanceamento entre os atributos sociais, econômicos e ambientais nas tomadas de decisão, possibilitando, desta forma, uma boa governança ambiental da questão.

Deste modo, a importância da ferramenta análise de risco na avaliação de OGMs em geral reside na possibilidade de fornecer os atributos ambientais a serem avaliados em estudos locacionais, com auxílio de outras metodologias, tais como cenarização, análise custobenefício, matriz de avaliação de impactos, dentre outros. Tal fato se dá pelo entendimento que o instrumento em si apenas indica os fatores, não possibilitando a obtenção de resultados numéricos, devido ao desconhecimento atual a respeito das magnitudes dos potenciais impactos derivados com o cultivo de plantas geneticamente modificadas. A partir do momento em que mais pesquisas sejam realizadas neste sentido e, portanto, uma maior experiência possa ser adquirida com a prática, é possível que a análise de risco possua um embasamento científico consolidado para ser aplicada como uma metodologia que subsidie as tomadas de decisão, no tocante aos fatores ambientais do meio. No entanto, mesmo assim, há necessidade do emprego de outras ferramentas que considerem as Políticas, Planos e Programas da área de liberação, um aspecto não presente na análise de risco, como anteriormente observado.

A seguir, serão examinadas as potencialidades dos instrumentos de avaliação de impactos ambientais, quais sejam, os Estudos de Impacto Ambiental, utilizados para a avaliação de Projetos e a Avaliação Ambiental Estratégica, que avalia Políticas, Planos e Programas em atender os aspectos acima apontadas e suas possíveis interfaces com a análise de risco.

\subsubsection{O Estudo de Impacto Ambiental.}

Como visto anteriormente, o EIA se objetiva a analisar a viabilidade ambiental de 
projetos pontuais como subsídios à tomada de decisões (HIRVONEN, 2007). Para tanto, procede-se a uma análise das suscetibilidades e vocações do meio perante a tipologia do empreendimento (SOUZA, 2000).

A Resolução CONAMA 01/86, que regulamenta os estudos de impacto ambiental no Brasil, explicita a necessidade de considerar as características ambientais, sociais e econômicas do meio nas avaliações, contemplar as alternativas tecnológicas e locacionais do projeto, delimitar sua área de influência e a compatibilidade da proposta com as Políticas e Programas elaborados para a localidade. Como visto, o EIA é um dos estudos ambientais utilizados para o licenciamento de atividades potencialmente poluidoras, dentre as quais se encontram a introdução de OGMs. Entretanto, a realização destes estudos é condicionada à solicitação da CTNBio.

A Resolução CONAMA 237/97 atribuiu ao IBAMA a realização do licenciamento ambiental em âmbito nacional e regional, considerando as especificidades locais em termos ambientais, sociais e econômicos. A Resolução 305/02 determina a tal órgão a realização de um macrozoneamento ambiental para a introdução de OGMs, considerando o exame técnico procedido pelos estados, os quais devem ser consultados durante o processo de licenciamento:

O Instituto Brasileiro do Meio Ambiente e dos Recursos Naturais Renováveis
- IBAMA fará o licenciamento ambiental, definido no inciso II do caput deste
artigo, por meio de macrozoneamento ambiental ${ }^{1}$ das áreas para a liberação
do OGM, considerando as especificidades biogeográficas e sócio-econômicas
relevantes, conforme a Lei $6938 / 81$, e o exame técnico procedido pelos
estados, quando houver.

Até o momento, foi efetuado o macrozoneamento das zonas de exclusão do algodão Bt pelo Ministério da Agricultura, Pecuária e Abastecimento, tendo como critério limitante para a liberação a presença de três espécies de algodão, sendo uma nativa (Gossipium mustelinum) e duas domesticadas (G. barbadense e G. hirsutum), com o intuito da preservação de seu patrimônio genético, conforme Freire, 2000 apud EMBRAPA, 2003. Entretanto, outros fatores ambientais presentes nos critérios de análise de risco contidos na Resolução Normativa No.5, de 12 de março de 2008 da CTNBio foram desconsiderados neste estudo, tais como:

- A existência de organismos indicadores relevantes nos ecossistemas onde se pretende

\footnotetext{
${ }^{1}$ Delimitação de zonas no território nacional que podem abranger um ou mais ecossistemas, levando em consideração as especificidades biogeográficas e sócio-econômicas, que possam indicar adequação ou restrição para a liberação do uso comercial de OGM. (BRASIL, 2002).
} 
efetuar o seu cultivo, em comparação com o organismo parental do OGM, para os estudos de análise de risco;

- A distribuição geográfica dos potenciais agentes polinizadores do algodão no Brasil;

- Características do solo, a fim de prever os efeitos advindos da transferência horizontal para a microbiota do solo, suas potenciais alterações físicas e químicas, assim como a biodegradabilidade da planta transgênica.

Tais aspectos, arrolados na análise de risco, dependem das especificidades dos ambientes de liberação, que apresentam variações geográficas, ainda mais se forem levadas em conta as amplas dimensões territoriais do país. Um estudo como o EIA ou a análise de risco não permitem que se contemplem estas diferenças, por serem avaliações pontuais, de locais específicos. O EIA, de modo geral, não possui competência para a sistematização das informações ambientais em amplas escalas geográficas visando a indicação de locais suscetíveis e adequados aos empreendimentos. Tais estudos necessitam de outro instrumento de diagnóstico e avaliação de impactos ambientais no âmbito do planejamento ambiental.

Como procedimento comum a EIAs, uma das exigências para o licenciamento ambiental é a apresentação de alternativas locacionais e tecnológicas para o projeto, as quais devem ser confrontadas com a hipótese de sua não execução (BRASIL, 1986). Os estudos ambientais devem contemplar as áreas de influência diretas e indiretas da atividade, considerando-se uma determinada base geográfica para a gestão, o diagnóstico dos meios biótico, físico e sócio-econômico, a análise de riscos ambientais, a aplicação de medidas compensatórias e mitigadoras dos impactos e os planos e programas ambientais relacionados à atividade. Deste modo, fica explícito que a AR é apenas um componente do EIA, não o substituindo e que estudos locacionais são indispensáveis para a tomada de decisões.

Os EIAs, de modo geral, devem contemplar consultas à população diretamente afetada ou interessada pelo empreendimento, sendo as audiências públicas o mecanismo participativo comumente utilizado. O anexo II da Resolução CONAMA 305/02, também menciona a necessidade de se considerar as disposições legais relacionadas à proteção dos recursos naturais, incluindo as decisões sobre liberações em outros países e suas restrições., além das PPPs relacionadas à atividade em questão.

Entretanto, por tratar-se de um instrumento que analisa a viabilidade de uma atividade pontual, as Leis, Políticas, Planos e Programas elaborados para uma determinada localidade são dificilmente considerados em um EIA, por se tratar de um instrumento de licenciamento ambiental e não de planejamento, o qual envolve áreas geográficas mais abrangentes e suas ações estratégicas. 
A dificuldade do EIA em considerar outras legislações e PPPs referentes à área de liberação de OGMs que, no Brasil, é realizada para todo o território nacional, impede que medidas preventivas e mitigadoras sejam levadas em conta nos processos decisórios, tais como a restrição de plantio em determinadas áreas ambientalmente frágeis ou que possuam vocações econômicas e sociais que se choquem com tal sistema produtivo, podendo ocasionar impactos ambientais e sócio-econômicos negativos nestas localidades.

Outra etapa constituinte do Estudo de Impacto Ambiental é o levantamento e análise de alternativas tecnológicas e locacionais, Durante os estudos de impacto ambiental de OGMs, o empreendedor deve efetuar uma análise comparativa entre o empreendimento e outras alternativas tecnológicas relacionadas à sustentabilidade, considerando os impactos ambientais, à saúde e ao meio sócio-econômico. De acordo com a Resolução CONAMA No 305/02, o licenciamento ambiental destas variedades necessita, para ser efetuado, do parecer técnico consultivo da CTNBio e a identificação e diagnóstico ambiental das áreas onde se pretende liberar o OGM, considerando sua região geográfica. Para a análise das alternativas locacionais e tecnológicas, o órgão ambiental deve "contemplar as vantagens e desvantagens de cada alternativa locacional e tecnológica, confrontando-a com a hipótese da não execução da atividade ou empreendimento" (BRASIL, 2002, anexo II, 4).

Entretanto, como mencionado anteriormente, durante as análises para a liberação em escala comercial de PGMs não se contemplam suas possíveis alternativas locacionais e as variedades têm seu plantio autorizado em todo o território nacional. A única exceção existente são as áreas de exclusão dispostas para o algodão Bt, como mencionado, que se baseia apenas em um único fator ambiental, qual seja, a presença de espécies de algodão nativas e a proibição do cultivo de PGMs no entorno das Unidades de Conservação e em terras indígenas. A ponderação de alternativas é difícil de ser realizada via EIA/RIMA, por conta de seu enfoque em atividades pontuais. A ausência de planejamento ambiental, momento em que as alternativas de desenvolvimento são analisadas e escolhidas, impossibilita o levantamento de alternativas locacionais e de tipologia de empreendimentos. Deste modo, os modelos de desenvolvimento não são debatidos de forma prévia com a sociedade e o EIA termina por endossar os interesses do setor público ou privado (GLASSON; SALVADOR, 2000).

Segundo Ebisemiju (1993 apud GLASSON; SALVADOR, 2000, p. 192), ao discorrer sobre as dificuldades do EIA nos países em desenvolvimento:

[...] as avaliações ambientais são conduzidas no estágio tardio do planejamento e design do projeto, quando a maioria dos detalhes finalizou e 
há pouca ou nenhuma oportunidade para considerar alternativas. O EIA então se torna proscrito ao planejamento e é utilizado basicamente para endossar ações públicas ou privadas ao invés de influenciar nas decisões.

Dentre os estudos ambientais necessários ao licenciamento ambiental de OGMs encontram-se:

- características do OGM: dados taxonômicos; biológicos; geográficos; biológicos; sobre o inserto e sua transferência para o receptor e as características ecológicas do meio;

- a caracterização do meio físico: destacar os fatores que possam acarretar o escape gênico não intencional, tais como ventos e enchentes.

- caracterização do meio biótico: a composição florística e faunística das áreas de introdução de OGMs, das áreas de preservação permanente e dos centros de diversidade genética.

- As áreas de influência direta e indireta da implantação do OGM, definindo os limites geográficos a ser impactados. Tais aspectos não são contemplados pela CTNBio.

- caracterização sócio-econômica: o EIA exige uma avaliação de impactos sócioeconômicos para a liberação comercial de OGMs a curto, médio e longo prazo, considerandose as populações que possam vir as ser afetadas direta ou indiretamente, suas expectativas em relação às atividades pretendidas no local, o uso e ocupação do solo no meio rural e urbano, a infra-estrutura do município, proximidade com assentamentos indígenas e outros assentamentos populacionais.

No entanto, não é possível para tais estudos considerar usos do solo pretendidos atuais e futuros, pois estes devem ser contemplados em um planejamento prévio, com a observância das áreas de influência do empreendimento.

$\mathrm{Na}$ fase de avaliação de impactos por meio de EIA, estes devem ser "descritos, quantificados, qualificados e classificados de acordo com a magnitude, importância, duração, época de ocorrência e reversibilidade" (BRASIL, 2002, anexo II, 5.6), implicando na consideração de uma temporalidade que pode se estender para além do ciclo de vida do projeto, considerando seus impactos cumulativos. Neste sentido, determina a necessidade de identificar e mitigar os potenciais impactos cumulativos derivados do cultivo contínuo de OGMs, sendo que a avaliação destes impactos necessita contemplar os efeitos da atividade com outras atuais ou futuras situadas em sua área de influência, como observado em Thérivel (2004). Entretanto, o instrumento EIA é realizado apenas para uma única atividade, o que compromete esta ponderação. 
De acordo com a Lei de Biossegurança, os EIA/RIMA apenas são exigidos no caso de a CTNBio detectar possíveis impactos ambientais em sua análise de risco. Como até então todas as variedades liberadas foram consideradas seguras ambientalmente, dada a afirmação de sua equivalência substancial aos cultivos convencionais, nenhum EIA para OGM foi realizado no país. No entanto, mesmo que exigido o EIA, o instrumento não se adequa a uma análise ambiental para um território amplo, impossibilitando o levantamento de alternativas locacionais e tecnológicas, como anteriormente exposto.

Na Resolução CONAMA 305/02, não há exigência de monitoramento pós-comercial de longo prazo, uma etapa constituinte do EIA no Brasil, mas que se dá apenas durante o ciclo de vida do empreendimento. Entretanto, um monitoramento de longo prazo é necessário no caso de liberações comerciais de PGMs, buscando-se identificar efeitos imprevistos, já que a ausência destes efeitos na atualidade não implica em sua inexistência futura (FEDERAL ENVIRONMENT AGENCY, 2001). A exigência de monitoramento apenas durante o ciclo de vida do projeto não permite que tais impactos sejam detectados, devido sua natureza de longo prazo (UNITED NATIONS ENVIRONMENTAL PROGRAMME, 2004).

Um Plano de Contingência se faz presente na Resolução CONAMA 305/02, na hipótese de acidente ambiental, sendo o proponente obrigado a recuperar e indenizar o meio ambiente e as pessoas afetadas, de acordo com a PNMA e a Lei de Crimes Ambientais, devendo informar os órgãos competentes e as comunidades afetadas. Entretanto, os efeitos potencialmente deletérios da introdução de PGMs podem se manifestar diversos anos após o término da atividade, o que torna necessária a realização de um monitoramento pós-comercial de longo prazo.

Glasson e Salvador (2000) e United Nations Environmental Programme (2004) apresentam uma série de dificuldades do EIA no cumprimento de suas funções, tais como:

$\checkmark \quad$ Dificuldades em garantir uma participação pública efetiva, já que a disposição de informações ao público é mais restrita, assim como sua participação nas tomadas de decisão.

$\checkmark \quad$ O instrumento dificilmente influencia momentos decisivos nas tomadas de decisão em âmbito de planejamento, sendo estas realizadas anteriormente ao EIA, quando da existência de planejamento, o qual muitas vezes não é realizado nos países em desenvolvimento;

$\checkmark \quad$ Dificuldades em realizar estudos ambientais na ausência de uma base de referência ambiental;

$\checkmark \quad$ Integração deficiente entre as dimensões sociais, econômicas e ambientais relacionadas ao empreendimento; 
$\checkmark \quad$ Baixo impacto dos relatórios de impacto sobre as ações de mitigação e monitoramento. Diversas vezes o monitoramento ambiental é inexistente;

$\checkmark \quad$ Falta de coordenação institucional das agências governamentais responsáveis em avaliar os estudos e garantir as obrigações do empreendedor. Este aspecto também dificulta a consideração de outras atividades a serem afetadas pela atividade proposta;

Tendo em vista as fragilidades do EIA apontadas e considerando que os estudos ambientais que precedem a liberação de OGMs são conduzidos para todo o país, sejam estes por meio de AR ou EIA/RIMA, pode-se observar a inadequação de ambos como únicos instrumentos que atendam à predição e avaliação dos impactos ambientais sob o prisma de uma boa governança ambiental, pelo fato de o EIA ser um instrumento de licenciamento para empreendimentos pontuais e a AR não considerar os potenciais impactos sociais, cumulativos e indiretos e a percepção da sociedade quanto à matéria em questão, além de outras PPPs. Além disto, a Resolução CONAMA $237 / 97$ torna patente a necessidade de um planejamento prévio às análises ambientais de empreendimentos sujeitos ao licenciamento ambiental, dentre os quais a introdução de OGMs se encontra.

Um instrumento adotado internacionalmente para avaliar ações que contemplem o planejamento ambiental é a Avaliação Ambiental Estratégica, que terá seu potencial de aplicação nas tomadas de decisão a respeito da liberação de PGMs em larga escala analisado.

\section{A Avaliação Ambiental Estratégica e a tomada de decisões sobre a liberação em escala comercial de PGMs.}

A liberação comercial de PGMs pode ser considerada uma ação estratégica, pelos seguintes motivos:

- $\quad$ Trata-se de uma questão eminentemente política, não somente técnica (tanto que a instância de tomadas de decisão definitiva sobre a liberação de OGMs é o CNBS, formado por 11 Ministros de Estado), pois envolve conflitos de interesses.

- Implica em um modelo agrícola baseado em monoculturas, influenciando os demais (policulturas, sistemas de cultivo convencional e alternativo). Portanto, relaciona-se ao planejamento do uso do solo agrícola;

- Do modo como são autorizadas para plantio, ou seja, para o território nacional como um todo, não se caracterizam como projetos pontuais. Neste sentido, pode-se considerar os processos remetidos à CTNBio como Planos ou Programas, que consolidam a Missão ou 
Política do MAPA e a Estratégia Nacional de Biotecnologia, ambas tendo por objetivo o estímulo à competitividade do país quanto ao desenvolvimento de PGMs;

- Apresenta impactos ambientais/sociais/econômicos potenciais de larga escala, cumulativos, sinérgicos, sejam positivos e/ou negativos;

- Relaciona-se com outras estratégias: legislações, políticas e tratados internacionais já mencionados;

Como anteriormente observado, os instrumentos Análise de Risco e Estudos de Impacto Ambiental, quando utilizados como únicas ferramentas para os estudos ambientais necessários às solicitações de liberação de PGMs não se demonstram suficientes para uma boa governança ambiental, já que:

- Não consideram as Políticas, Planos e Programas relacionados às potenciais liberações em âmbito federal, estadual e municipal;

- O Protocolo de Cartagena e a Lei de Biossegurança prevêem a realização de análises de risco caso-a-caso de PGMs, ou seja, que considere suas características e aquelas do meio em que será introduzida. Como as liberações são realizadas para todo o território nacional, as particularidades de cada local não são levadas em conta. Do mesmo modo, o EIA incorre no mesmo problema;

- Não permitem a avaliação dos impactos sociais, ambientais e econômicos cumulativos que potencialmente possam surgir com a introdução ambiental de diversas PGMs ao longo do tempo;

- O monitoramento previsto para ambos os instrumentos cessa após o término do cultivo, o que impossibilita a avaliação dos impactos negativos previstos e imprevistos que possam ocorrer em um horizonte temporal amplo;

- Da forma como são conduzidos no Brasil e em diversas nações, não possibilitam a participação social efetiva nas tomadas de decisão;

- Não consideram alternativas de localização e tecnológicas, de acordo com as peculiaridades ambientais, sociais e econômicas nas áreas de liberação;

- Não consistem em instrumentos de planejamento que contemplam as Políticas, Planos ou Programas para uma determinada localidade, em um horizonte de longo prazo. No caso do EIA, por exemplo, seu objetivo é o licenciamento ambiental de atividades pontuais.

Segundo Souza (2006), a falta de regulamentação de diversos instrumentos da Política Nacional de Meio Ambiente inviabiliza a eficácia do EIA, por atribuir-lhe funções que não lhe cabem. A falta de informações ambientais sistematizadas constitui-se em um exemplo que dificulta a realização de EIAs no Brasil, assim como a falta de planejamento ambiental. Neste 
sentido, um instrumento de planejamento que tem o potencial para contribuir aos aspectos acima abordados e que vem sendo utilizado em diversas nações é a Avaliação Ambiental Estratégica, ainda não implementada no Brasil, apesar da realização de alguns projetos-pilotos neste sentido. Contudo, o presente trabalho irá avaliar as possibilidades das contribuições da AAE.

De acordo com a Convenção sobre Diversidade Biológica, a avaliação de impactos ambientais de políticas e programas potencialmente causadores de danos ambientais deve ser utilizada como instrumento decisório, sendo que os países signatários devem aplicar a AAE e o EIA em propostas que impliquem em impactos negativos à biodiversidade, de modo a protegê-la e assegurar o uso compartilhado de seus benefícios (INTERNATIONAL ASSOCIATION FOR IMPACT ASSESSMENT, 2005).

A Política Nacional da Biodiversidade também explicita a importância de Avaliações Ambientais Estratégicas como instrumento de subsídio ao licenciamento ambiental:“[...] a integração entre o Zoneamento Ecológico-Econômico e as ações de licenciamento ambiental, especialmente por intermédio de Avaliações Ambientais Estratégicas feitas com uma escala regional" (13.2.4). O desenvolvimento de estudos de impacto ambiental e análise de riscos do uso de OGMs se faz necessário, como indicado no artigo 13.2.9.

Em outro momento, a realização de AAE para a utilização de OGMs é novamente citada nesta Politica (BRASIL, 2002b):

\begin{abstract}
Estabelecer mecanismos para determinar a realização de estudos de impacto ambiental, inclusive Avaliação Ambiental Estratégica, em projetos e empreendimentos de larga escala, inclusive os que possam gerar impactos agregados, que envolvam recursos biológicos, inclusive aqueles que utilizem espécies exóticas e organismos geneticamente modificados, quando potencialmente causadores de significativa degradação do meio ambiente.
\end{abstract}

Deste modo, a necessidade de avaliação prévia de impactos ambientais em situações de liberação em larga escala se faz presente na referida Política.

O planejamento ambiental possibilita uma abordagem transversal dos interesses da coletividade, ou seja, sociais, ambientais e econômicos, de modo a integrá-los por meio dos isntrumentos de política ambiental. A Avaliação Ambiental Estratégica é um instrumento de política ambiental que possibilita a realização de interfaces com diversos objetivos presentes no planejamento territorial. Deste modo, aos objetivos da Ação Estratégica em questão, no caso, a liberação para o cultivo comercial de plantas geneticamente modificadas, seriam 
somados outros objetivos identificados nos planos já elaborados para a unidade territorial em estudo que com esta se relacionam.

Dependendo da área geográfica em questão, pode-se efetuar uma AAE considerando os objetivos das legislações, Politicas, Planos e Programas existentes, tais como: as PPPs federais e os tratados internacionais, dentre os quais a Constituição Federal, a Política Nacional do Meio Ambiente, Política Agrícola, o Sistema Nacional de Unidades de Conservação, o Protocolo de Cartagena, Lei de Biossegurança, Política Nacional de Biotecnologia, Agendas 21 Global, Nacional e Local, a Convenção da Diversidade Biológica, a Política Nacional da Biodiversidade, a Lei de Orgânicos, Lei de Rotulagem, Lei de Defesa do Consumidor, Normativas da CTNBio, Lei de Proteção de Cultivares, Plano Purianual para a agricultura e o meio ambiente, PRONAF e demais Programas agrícolas e ambientais, os Planos Diretores regionais e municipais, dentre outros.

A interface entre as diversas Políticas, Planos e Programas governamentais é possibilitada pela AAE por meio da análise das compatibilidades entre a ação proposta (seus objetivos e instrumentos para concretizá-los) e outras estratégias de desenvolvimento delineadas para o território em questão, na forma de PPPs (THERIVEL, 2004). Apesar de a Resolução CONAMA No 01/86 definir que o EIA deve abranger as PPPs relacionadas ao empreendimento, tal premissa não é efetuada eficazmente, já que a atividade, na prática, tem sua localização e tipologia definidas previamente, sem considerar a escolha das opções de desenvolvimento desejadas pela sociedade. A AAE permite que os conflitos existentes devido aos diversos interesses quanto à estratégia em questão sejam clarificados e os critérios sociais, ambientais e econômicos identificados para a realização do macrozoneamento que será realizado a partir da base ou estudo de referência ambiental.

No Brasil, observou-se, quando da identificação dos conflitos sobre OGMs, a inexistência de uma Política Nacional de Biossegurança (PNB) que norteie os princípios e procedimentos para a proteção ambiental e da saúde humana e dos demais animais quando da realização de atividades que envolvam a manipulação de seres vivos por meio de engenharia genética. De acordo com Nodari, Guerra e Valle (2002) sua realização, no entanto, é fundamental para delinear os rumos da biossegurança e, consequentemente, da biotecnologia no país. Segundo estes autores, dentre seus princípios devem constar a transparência, precaução, publicidade e participação, a fim de proporcionar um maior controle pela sociedade. Também deve orientar a formação de parcerias entre empresas estatais e privadas, assim como entre entidades da federação, e entre os órgãos tomadores de decisão e os de vigilância e monitoramento. 
Para tais autores, a ausência de uma PNB tem levado à criação, por parte da CTNBio, de uma excessiva quantidade de normativas, muitas das quais dotadas de conteúdo conflituoso, ou com pouco detalhamento. Neste sentido, pode-se citar a normativa que dispõe sobre o monitoramento pós-comercial de OGMs, que não apresenta as diretrizes necessárias ao Plano de Monitoramento que necessita ser fornecido pelo proponente. Outro exemplo é a criação recente da normativa sobre os critérios indispensáveis à análise de risco, aprovada somente em 2008, após a liberação comercial de diversas variedades GMs.

A rotulagem seria outro procedimento necessário para possibilitar o desenvolvimento biosseguro destes organismos, que se encontra regulamentada, mas desconsiderada nas deliberações da CTNBio. Sua inclusão como um instrumento da PNB poderia torná-la mais eficaz desta forma. Deste modo, a avaliação de uma estratégia de liberação comercial de determinada PGM fica prejudicada sem o estabelecimento de uma PNB, já que os princípios norteadores para tanto não se encontram estabelecidos. Sobrepesa-se que sua inexistência também dificulta uma maior atuação da sociedade sobre as ações dos órgãos integrantes do sistema regulatório de OGMs no país.

No Brasil, alguns atores apontam para a prevalência de interesses econômicos nas políticas de biotecnologia, em nome do progresso científico e da competitividade internacional, em detrimento da segurança ambiental, de saúde e do bem-estar social (PELAEZ, 2004; INSTITUTO SOCIOAMBIENTAL, 2006). Um aspecto a ser mencionado neste sentido é o documento estratégico do Ministério da Agricultura, Pecuária e Abastecimento, que apresenta o posicionamento favorável do governo aos interesses da bioindústria, caracterizando a visão precaucionista sobre a liberação ambiental de OGMs como ideológica e contrária ao desenvolvimento econômico e à competitividade comercial do país em âmbito internacional (MINISTÉRIO DA AGRICULTURA, PECUÁRIA E ABASTECIMENTO, 2006, p.9):

Nossos concorrentes investem somas astronômicas em tecnologias de ponta, como a biotecnologia, incluindo os produtos transgênicos e a nanotecnologia. Precisamos nos manter atualizados na área, sob pena de sermos atropelados pela concorrência. É preciso sempre ter em mente que em matéria de pesquisa científica não cabem posturas preconceituosas ou ideologizadas.

Visando o estímulo ao desenvolvimento da biotecnologia no país, foi elaborada a Estratégia Nacional de Biotecnologia: Política de Desenvolvimento da Bioindústria, firmada 
como posição oficial do governo na área de biotecnologia, e que visa preparar o Brasil para se destacar como um dos líderes no setor dentro de 10 a 15 anos, com finalidade de:

[...] promover e executar ações com vistas ao estabelecimento de ambiente adequado para o desenvolvimento de produtos e processos biotecnológicos inovadores, estimular o aumento da eficiência da estrutura produtiva nacional, a capacidade de inovação das empresas brasileiras, absorção de tecnologias, a geração de negócios e a expansão das exportações [...].

(MINISTÉRIO DO DESENVOLVIMENTO, INDÚSTRIA E COMÉRCIO EXTERIOR, 2006, p.09)

Para tanto, a Estratégia focou-se em quatro áreas temáticas, abrangendo saúde humana, agronegócio, saúde animal e indústria, sendo que, para cada área foram definidas diretrizes, objetivos e custos estimados, considerando-se três áreas de análise: alvos estratégicos, definidos no âmbito empresarial como alvos com grande potencial de mercado a curto e médio prazos, tendo em vista o aumento da competitividade brasileira na área de biotecnologia; áreas priorizadas, constituindo-se em produtos de relevância para o atendimento das demandas sociais e com potencial de mercado significativo; e áreas de fronteira, inovações tecnológicas de alto valor agregado com potencial para novos mercados (MINISTÉRIO DO DESENVOLVIMENTO, INDÚSTRIA E COMÉRCIO EXTERIOR, 2006).

Com o intuito de se criar um ambiente adequado ao atendimento das necessidades da bioindústria brasileira, foi elaborado ações estruturantes abrangendo sistemas de financiamento, preparação de recursos humanos e infra-estrutura, além da consolidação de marcos regulatórios que se adéquem às finalidades pretendidas na Estratégia. No âmbito do financiamento, abordou-se a necessidade da criação de uma instância executiva no Comitê Nacional de Biotecnologia que vise o desenvolvimento de programas que atendam aos objetivos e metas de investimentos pretendidos. Como objetivo geral destaca-se a promoção de ações de fomento para a formação de empresas ou rede de empresas inovadoras na área de biotecnologia, utilizando-se, dentre outras ferramentas, de desoneração tributária para a modernização industrial e a exportação de produtos biotecnológicos (MINISTÉRIO DO DESENVOLVIMENTO, INDÚSTRIA E COMÉRCIO EXTERIOR, 2006). No entanto, a elaboração da Estratégia Nacional de Biotecnologia previamente à Política Nacional de Biossegurança pode dificultar que outras preocupações da sociedade, como a utilização segura destes produtos, sejam incorporadas na concretização desta estratégia. A elaboração da PNB, deste modo, seria um importante subsidio para a realização de uma AAE referente a 
Planos de Pesquisa sobre OGMs e Programas governamentais e privados de liberação comercial de PGMs, como uma das Políticas a lhe fazerem interface.

As Figuras 9 e 10 apresentam, respectivamente, o processo atual que culmina na estratégia de liberação de PGMs em âmbito comercial (sem considerar outras PPPs) e o procedimento desejável, considerando a interface com outras estratégias de planejamento, possibilitada pela AAE. A interferência deste instrumento neste exemplo ocorreria no momento de execução de Programas de liberação de PGMs específicas (tais como algodão $\mathrm{RR}$, algodão $\mathrm{Bt}$, soja $\mathrm{RR}$, dentre outras), pelo fato de as Políticas de estímulo à biotecnologia e os Planos de Pesquisa em OGMs não serem objetos deste trabalho. Dentre as Políticas que fazem a interlocução com a estratégia de liberação comercial de uma PGM se inclui a Política Nacional de Biossegurança, que será representada em tracejado, devido a sua inexistência.

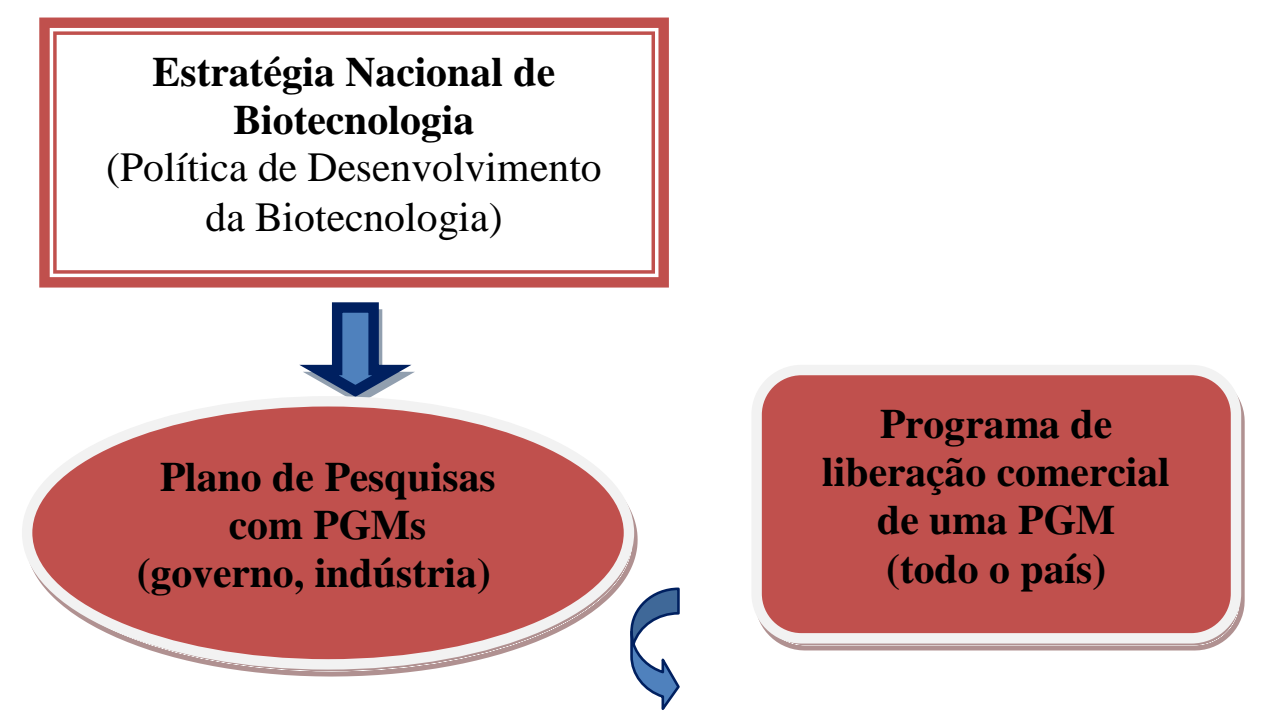

Figura 10 - Processo atual que conduz à estratégia de liberação comercial de PGMs Fonte: Modificado de Oliveira (2008). 


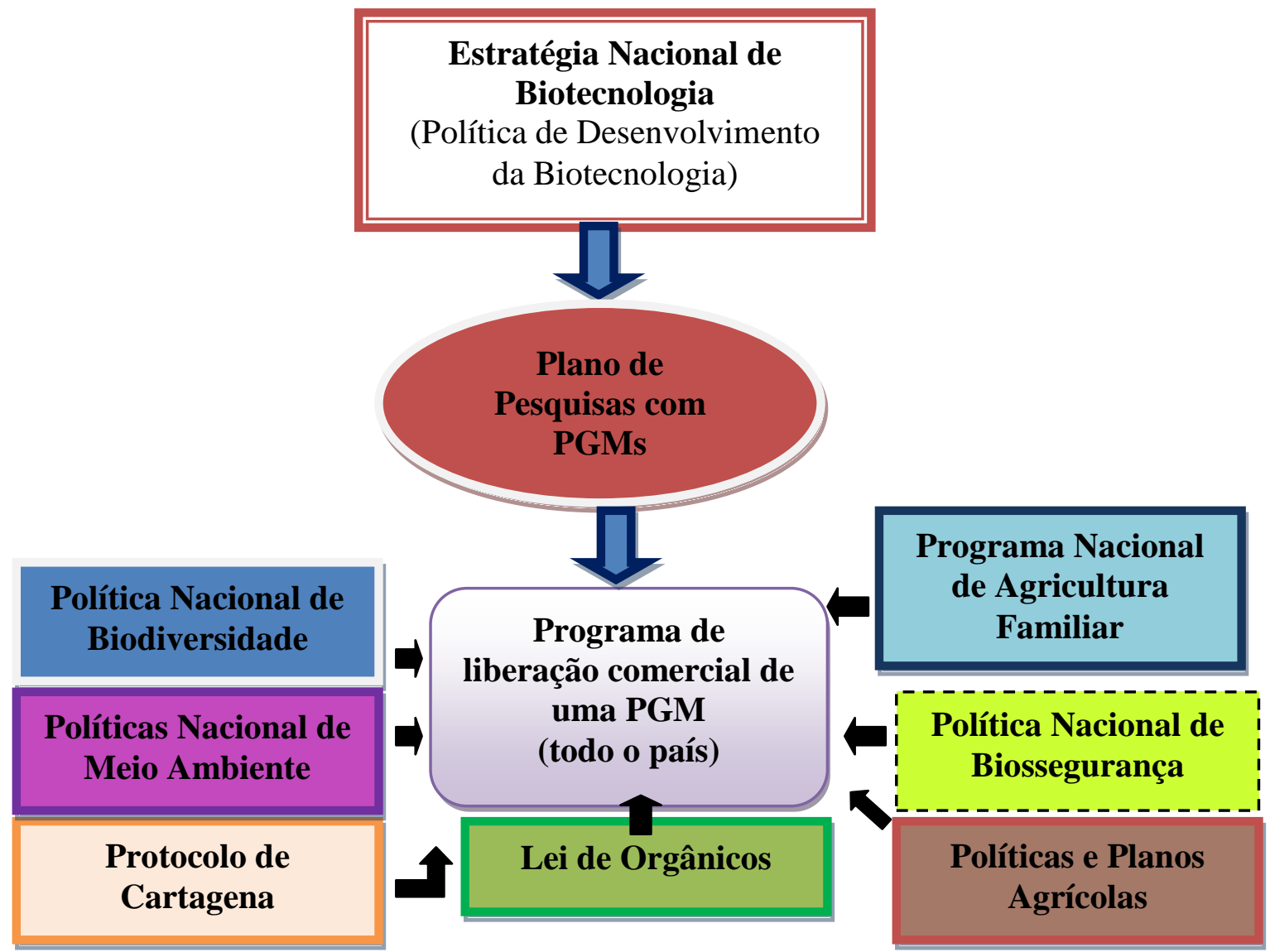

Figura 11 - Consideração de Leis e PPPs que fazem interface com a estratégia de liberação comercial de PGMs, possibilitada pela AAE.

Depois de realizadas as interfaces com outras PPPs, a etapa de construção da base ambiental se configura como um dos elementos chave do processo de AAE, por permitir uma avaliação sistemática das informações ambientais relevantes que possibilitem a identificação de problemas ambientais e sócio-econômicos reais ou potenciais da ação proposta em territórios amplos (THERIVEL, 2004). A partir dos critérios relevantes para a liberação biossegura da PGM na área de abrangência, que pode ser um bioma, estado ou região, utilizando-se os termos de referência do EIA, por exemplo, além dos critérios empregados na análise de risco e outros que contemplem os anseios da coletividade, pode-se efetuar o macrozoneamento ambiental para cada PGM ou grupo de PGMs que possuam características similares. A partir da elaboração do macrozoneamento, o órgão tomador de decisão pode estabelecer os locais de liberação e, se necessário, seus condicionantes, visando prevenir a ocorrência de potenciais danos. Deste modo, alternativas locacionais, tecnológicas e de desenvolvimento para a liberação podem ser levantadas, uma atribuição que não pode ser efetuada pelo EIA ou a Análise de Risco. A necessidade de comparar as alternativas 
relacionadas à ação estratégia em estudo se dá em razão de o uso de OGMs na agricultura se configurar como uma opção de desenvolvimento, que necessita ser analisada perante outras em seus riscos e benefícios, sendo que a decisão final necessita atender aos anseios da nação sob o prisma do desenvolvimento sustentável, nos princípios de equidade social, desenvolvimento econômico e proteção ambiental. A aplicação da AAE é uma ferramenta que possibilita a tomada de decisão sob esta ótica e, portanto, facilita um maior controle social por minimizar a predominância de interesses setorizados. A elaboração de alternativas locacionais e de desenvolvimento possibilita, por meio de cenários ambientais envolvendo a análise e predição de impactos, um embasamento científico abrangente para a escolha da melhor alternativa apresentada (PARTIDÁRIO, 2002). A AAE é fundamental para subsidiar as tomadas de decisão nos processos iniciais de planejamento, fornecendo uma visão ampla dos impactos indiretos e cumulativos das alternativas propostas, que não são passíveis de serem analisados por EIAs, que tratam de atividades pontuais e não de larga escala (THERIVEL, 2004). De acordo com Souza (2006), a base ambiental, na medida em que possibilita a sistematização de informações ambientais em termos geográficos, auxilia tanto o planejamento territorial, quanto à realização de EIAs. Dentre as contribuições da base ambiental situam-se as análises de alternativas locacionais, delimitação da área de influência e definição dos termos de referência para empreendimentos.

Por meio da existência de informações ambientais sistematizadas na base ambiental, é possível estabelecer, com a participação de uma equipe técnica multidisciplinar, de órgãos governamentais e de organizações da sociedade civil interessadas, as áreas mais frágeis e mais adequadas ao cultivo de PGMs, utilizando os indicadores da AAE.

Diversos trabalhos vêm sendo realizados nos países da União Européia buscando-se utilizar modelos computacionais aliados a geoprocessamento por meio de Sistemas de Informação Geográfica que visam simular a dispersão de OGMs em âmbito temporal e espacial, de modo a permitir o estudo de localização para seu plantio. Um exemplo é encontrado no trabalho de Middelhoff; Reiche e Windhorst (2009), tendo como estudo de caso uma variedade GM de canola. O objetivo do trabalho foi elaborar estudos de localização para o plantio de canola de modo a prevenir a contaminação genética de variedades convencionais e orgânicas em âmbito regional. Para tanto, um modelo de simulação foi desenvolvido para calcular o padrão espacial-temporal da dispersão da PGM, em configurações espaciais de $1 \mathrm{Km}^{2}$ considerando informações climáticas e sistemas de cultivo em âmbito regional. O trabalho permitiu a predição do número total de PGMs que florescem na região em um período de tempo determinado, possibilitando a realização de 
recomendações aos tomadores de decisões sobre a densidade do cultivo, as alternativas de localização, o monitoramento pós-comercial e análise custo-benefício para sua liberação, de forma a evitar uma possível contaminação genética. No entanto, para a realização de uma base ambiental, necessita-se de informações ambientais muitas vezes inexistentes nos órgãos governamentais brasileiros, apesar de a PNMA incubir ao Poder Público sua coleta e disponibilização ao instituir o sistema de informações ambientais como um de seus instrumentos. Na ausência de dados, o processo inicial para a criação de uma base ambiental é, deste modo, dificultada. Entretanto, assim como para o EIA, apenas as informações necessárias para a avaliação devem ser utilizadas, evitando a perda de tempo e recursos que poderiam dificultar sobremaneira a AAE. Dentre as informações necessárias para a realização de uma base ambiental que subsidie uma AAE para PGMs, podem-se exemplificar:

$\checkmark$ Localização de Unidades de Conservação e áreas especialmente protegidas com especial atenção àquelas que possuam espécies alvo que possam ser impactadas negativamente pela introdução da PGM em questão;

$\checkmark$ Localização de cultivos a serem protegidos de possíveis contaminações por material transgênico, tais como as culturas orgânicas, sistemas convencionais de produção e aquelas que recebam subsídios do PRONAF que, como anteriomente observado, proíbem o plantio de transgênicos;

$\checkmark$ A identificação das espécies-chave para o funcionamento do ecossistema (ou ecossistemas) da área de abrangência da AAE. Nestes, a identificação das potenciais espéciesalvo que possam ser afetadas direta ou indiretamente pela introdução da PGM e seu agroquímico associado, no caso de PGMs resistentes a herbicidas ou produtoras de inseticidas;

$\checkmark$ Os padrões de qualidade ambiental para a água e o solo;

$\checkmark$ As terras indígenas e outras áreas de restrição.

As ferramentas para a avaliação de impactos ambientais em AAE dependem do objeto em avaliação, ou seja, se se trata de uma Política, Plano ou Programa e do recorte territorial envolvido (PARTIDÁRIO, 2002). Em casos de grandes incertezas quanto aos potenciais impactos, como a liberação de PGMs, as metodologias mais indicadas são cenarização ambiental, análise multicriterial, checklists, redes de interação e a análise de risco (HENRY, 2006; STIRLING, 2000). Deste modo, pode-se inferir que a AR é uma ferramenta metodológica utilizada para a predição de impactos ambientais tanto em AAE quanto em EIA. Além do diálogo com outras PPPs, da construção da base ambiental e do levantamento e avaliação de alternativas, uma das premissas da AAE é sua natureza participativa, possibilitando que o julgamento sobre o problema em questão não permaneça em mãos de determinados setores da sociedade, excluindo os demais agentes afetados pelas tomadas de 
decisão. Além disto, formas de negociação podem ser propiciadas, de modo a se criar um consenso que implique na minimização de conflitos, já que os diversos pontos de vista podem ser considerados (THERIVEL, 1994).

A elaboração de um planejamento setorial de longo prazo em um Estado democrático necessita de uma ampla participação social prévia e processual, abrangendo os setores interessados e afetados. As incertezas científicas sobre as consequências da liberação no meio ambiente de PGMs tanto aos ecossistemas quanto à saúde humana e às cadeias produtivas requerem análises ambientais que abranjam não apenas conteúdos técnicos, mas também questões de caráter ético que reflitam a posição dos grupos sociais envolvidos. Neste sentido, os estudos ambientais necessários para as deliberações sobre a comercialização de culturas geneticamente modificadas necessitam da constituição de fóruns de debate com representantes da sociedade e dos governos federal, estadual e municipal, permitindo uma maior transparência no processo. Sendo uma fase prévia ao processo, possibilita o envolvimento do público interessado na elaboração da ação estratégica, garantindo uma maior transparência. No caso em questão, é possível identificar os possíveis agentes sociais de uma AAE por meio da observação dos participantes das audiências públicas até então realizadas e por meio da literatura sobre o tema, quais sejam: órgãos governamentais responsáveis pela regulação de OGMs, especialistas em biotecnologia, biossegurança, ecologia, meio ambiente, direito, sociologia, agronomia, engenharia florestal, produtores rurais (que possuam grandes, médias ou pequenas propriedades), organizações da sociedade civil relacionadas à terra e ao meio ambiente, dentre outros. No questionário realizado neste trabalho, procurou-se envolver representantes destas diversas áreas de interesse sobre assunto e identificar outras que possam contribuir para o debate. Caso haja uma decisão favorável à liberação de determinada variedade de PGM em uma unidade territorial específica, uma vantagem do uso da AAE é possibilitar um monitoramento pós-comercial contínuo que vise a retroalimentação da decisão tomada. O monitoramento é fundamental para a detecção dos impactos potenciais previstos nas fases de escopo e avaliação (com determinação de seu grau de amplitude e magnitude) da AAE, assim como aqueles imprevistos. Desta forma, podem-se adotar medidas mitigadoras, preventivas e mesmo a reavaliação da escolha tomada.

O monitoramento requer metodologias que promovam a integração entre os aspectos espaciais e temporais dos ecossistemas ou de outro recorte territorial abordado. Para Graef et al. (2004), a unidade territorial propícia para efetuar o monitoramento é a ecorregião, em função da existência de uma certa homogeneidade florística e faunística em sua composição. Tais autores salietam as dificuldades de identificação dos riscos e benefícios potenciais da 
liberação ambiental de PGMs devido à complexidade dos ecossistemas, sendo que seus impactos ambientais variam espacial e temporalmente de acordo com as características agroambientais, do cultivo e sua modificação genética, além das práticas agrícolas adotadas. Neste sentido, enfatizam a necessidade de informações sobre os fatores ambientais escolhidos e a utilização de sistemas de georreferenciamento para identificar os locais mais adequados para a delimitação de sistemas de monitoramento ambiental. O monitoramento de PGMs necessita, previamente, da definição de indicadores ambientais, sociais e econômicos definidos na fase de escopo, cuja distribuição apresenta variações de acordo com as condições ambientais, sociais e econômicas locais. Neste sentido, um sistema de planejamento para a delimitação dos locais a serem monitorados trás a imprescindibilidade de informações sistematizadas que perfazem a construção da base ambiental, anteriormente utilizada para a identificação dos locais preferenciais à introdução de PGMs, caso se decida liberá-las. A implementação da AAE no planejamento ambiental pode trazer contribuições neste sentido, dada sua característica em lidar com amplas áreas geográficas, tanto nos estudos de localização de implementação de PPPs quanto no seu subsequente monitoramento. Já o EIA, apesar de regulamentado para abranger as áreas de influência de empreendimentos e efetuar seu monitoramento ao longo do ciclo de vida, dificilmente cumpre seu papel sem a prévia existência de avaliações de áreas geográficas amplas. Desta forma, a AAE é uma ferramenta aplicável para o monitoramento ambiental, especialmente em casos de imprevisibilidade dos impactos, uma característica intrínsica das PGMs. Para melhor ilustrar a proposição de uma estratégia de liberação comercial de uma PGM sem o emprego da AAE e as potenciais contribuições se esta fosse aplicada, será apresentado um Programa hipotético elaborado por uma entidade pública ou privada produtora de PGM, por meio da Figura 12. 


\section{Ação Estratégica}
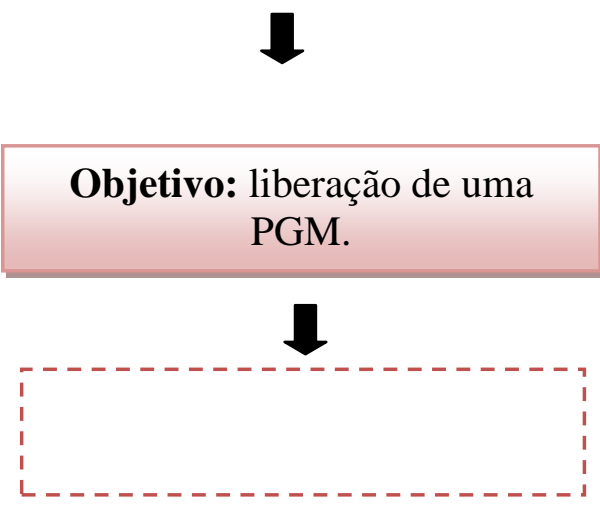

パール

バーン

(1)

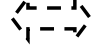
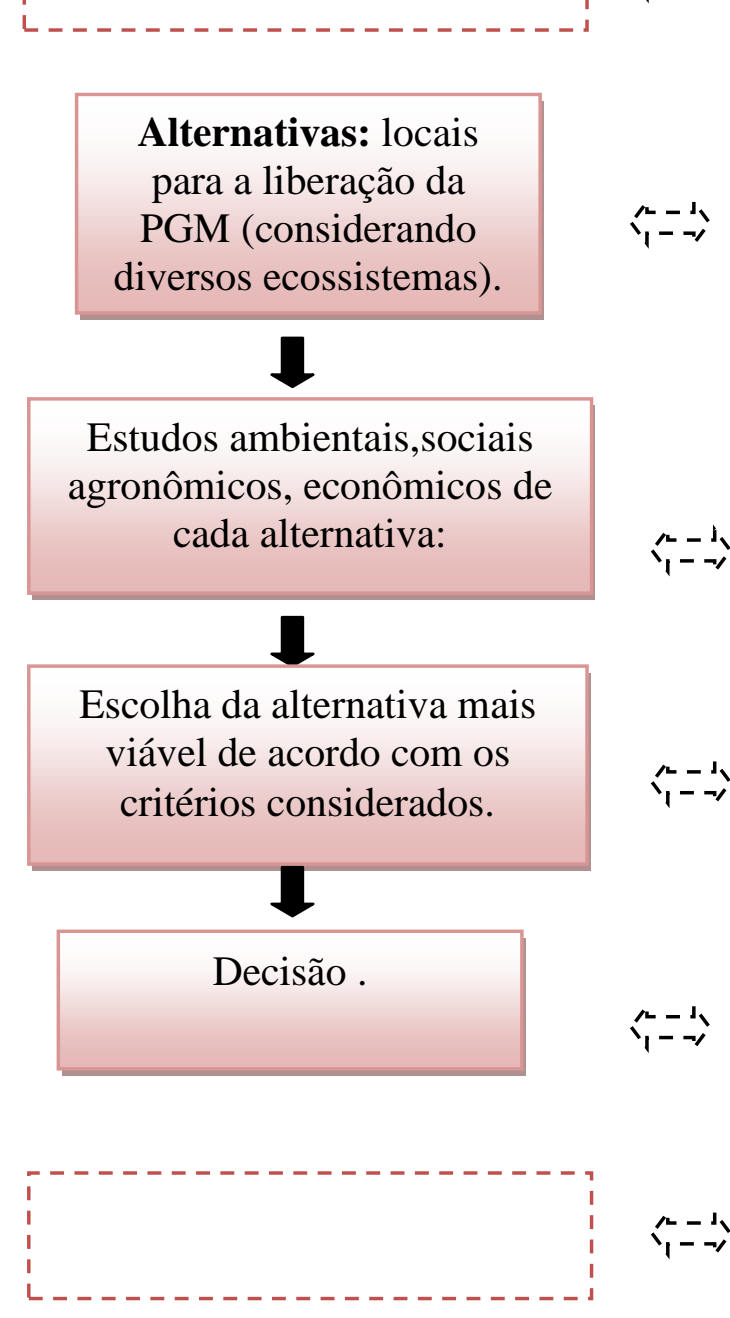

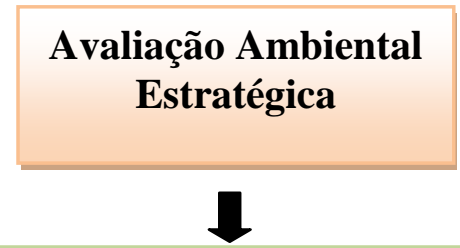

Objetivos: avaliar o processo de pesquisa e de testes para a liberação da PGM do ponto de vista da sustentabilidade

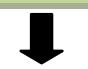

Identificar agentes sociais para a participação.

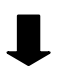

Base ambiental e interface com outras ações estratégicas; Indicadores

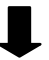

Levantar alternativas mais sustentáveis.

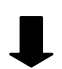

Avaliação de impactos de cada alternativa frente às peculiaridades locais.

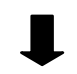

Escolha da(s) alternativa(s) mais sustentável(s).

Mitigar impactos potenciais $\mathrm{da}(\mathrm{s})$ alternativa(s).

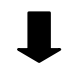

Monitoramento contínuo

Fig.12 - Proposta de liberação comercial de planta geneticamente modificada sem a utilização da AAE. 
Nota-se na Figura 12, que as principais potencialidades da AAE em propiciar uma tomada de decisões de modo a levar em conta os interesses dos diversos setores sociais envolvidos possibilitando a inserção da variável ambiental neste processo são:

$\checkmark$ a participação social por meio de uma maior representatividade de interesses da coletividade em todas as etapas do processo, desde o levantamento de alternativas locacionais, os critérios selecionados para a avaliação de impactos, os mecanismos de mitigação, a tomada de decisão pelo órgão competente e as regras para o monitoramento;

$\checkmark$ a consideração dos interesses da população também perpassa pela interface com outras ações estratégicas, que podem não se fazer presentes na estratégia da empresa;

$\checkmark$ por meio da existência de informações ambientais sistematizadas em uma base ambiental, possibilita-se que se levante as alternativas mais sustentáveis, podendo influenciar na definição de alternativas locacionais;

$\checkmark$ com a AAE, os estudos ambientais e de caráter social e econômico necessitam levar em conta as especificidades locais, subsidiando a tomada de decisão pela empresa proponente e o pelo órgão responsável pela avaliação da ação estratégica;

$\checkmark$ sem a base ambiental, indispensável em uma AAE, propostas de mitigação de impactos são dificultadas;

$\checkmark$ a exigência do monitoramento pós-comercial cabe ao órgão competente, mas até então não foi implementado no país. A AAE necessita de um monitoramento ambiental contínuo, que pode conduzir inclusive à modificação da ação estratégica e da própria AAE realizada. Uma contribuição neste sentido também é solicitar ao órgão decisório o monitoramento.

Sendo a AAE um instrumento de planejamento territorial e que, portanto, realiza a interface com as demais ações estratégicas elaboradas para o local em questão presentes em Políticas, Planos e Programas, pode-se ilustrar sua importância no tocante a tal aspecto incluindo os Programas de liberação de plantas geneticamente modificadas em uma estrutura hierárquica superior, como um Plano agrícola, ambiental, econômico, dentre outros. Esta inclusão possibilita que se considere alternativas de desenvolvimento, visto que a agricultura transgênica é uma das diversas opções de sistemas agrícolas existentes. Caso se considere a elaboração de uma AAE para uma Política de Biotecnologia ou um Programa de liberação de PGM elaborada por uma empresa, seja governamental ou privada, outras opções de agricultura não seriam consideradas, por não serem objetivos destas referidas ações. Deste modo, será apresentado um Plano setorial Agrícola hipotético para um Estado ou região e a inserção do cultivo transgênico como uma alternativa, ao mesmo tempo em que se apresenta o potencial da AAE na elaboração e consecução deste Plano, conforme a Figura 13. 


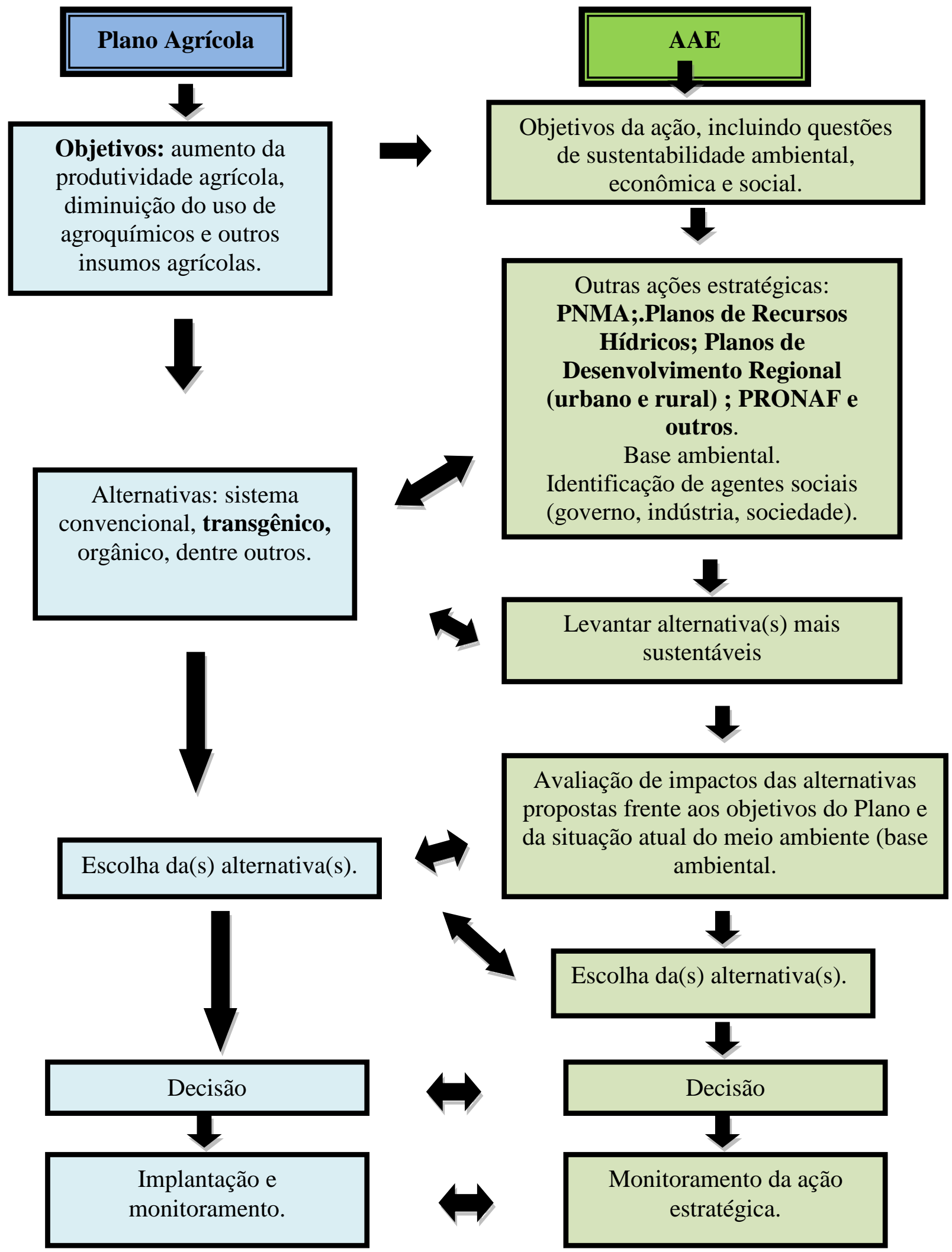

Figura 13 - Exemplo de uma ação estratégica envolvendo a liberação comercial de PGMs e os passos da AAE.

Deste modo, pode-se concluir pela possibilidade de aplicação da Avaliação Ambiental 
Estratégica para a liberação comercial de PGMs, já que, dados os seus princípios e procedimentos, permite um melhor balanceamento entre as diversas visões sociais a respeito do assunto e contribui para a prática de uma boa governança ambiental. Tal fato se dá por se tratar de uma ação que possui implicações ambientais, sociais, culturais e econômicas de largo espectro, com potencial de suscitar impactos ambientais cumulativos e indiretos resultantes de liberações sucessivas em um mesmo local ou em suas adjascências (considerando uma ou mais variedades GMs), fazer interface e mesmo se confrontar com outras ações estratégicas e objetivos da sociedade, além de possuir um elevado grau de incerteza, dentre outros aspectos.

Entendendo-se que as liberações em escala comercial podem se sujeitar à realização de uma AAE, o Estudo de Impacto Ambiental pode ser aplicado para a avaliação de atividades pontuais com PGMs, como a liberação em um agroecossistema. A análise de risco, por sua vez, pode ser utilizada como uma ferramenta que subsidie a avaliação de impactos, como observado na Resolução CONAMA No 305/02. No entanto, é importante salientar que a AAE e o EIA são instrumentos de AIA que se complementam, pois as informações mais generalizadas, de conteúdo estratégico da AAE, subsidiam a elaboração dos termos de referência do EIA e os resultados destes, obtidos por estudos mais detalhados e com o monitoramento, podem levar a adaptação da ação estratégica. A Análise de Risco, por sua vez, é uma importante ferramenta para fornecer critérios a serem ponderados nos estudos ambientais, tanto para a criação de parte dos termos de referência do EIA quanto para a elaboração do macrozoneamento ambiental que auxilia a AAE. A figura 14 ilustra as interfaces entre cada instrumento:

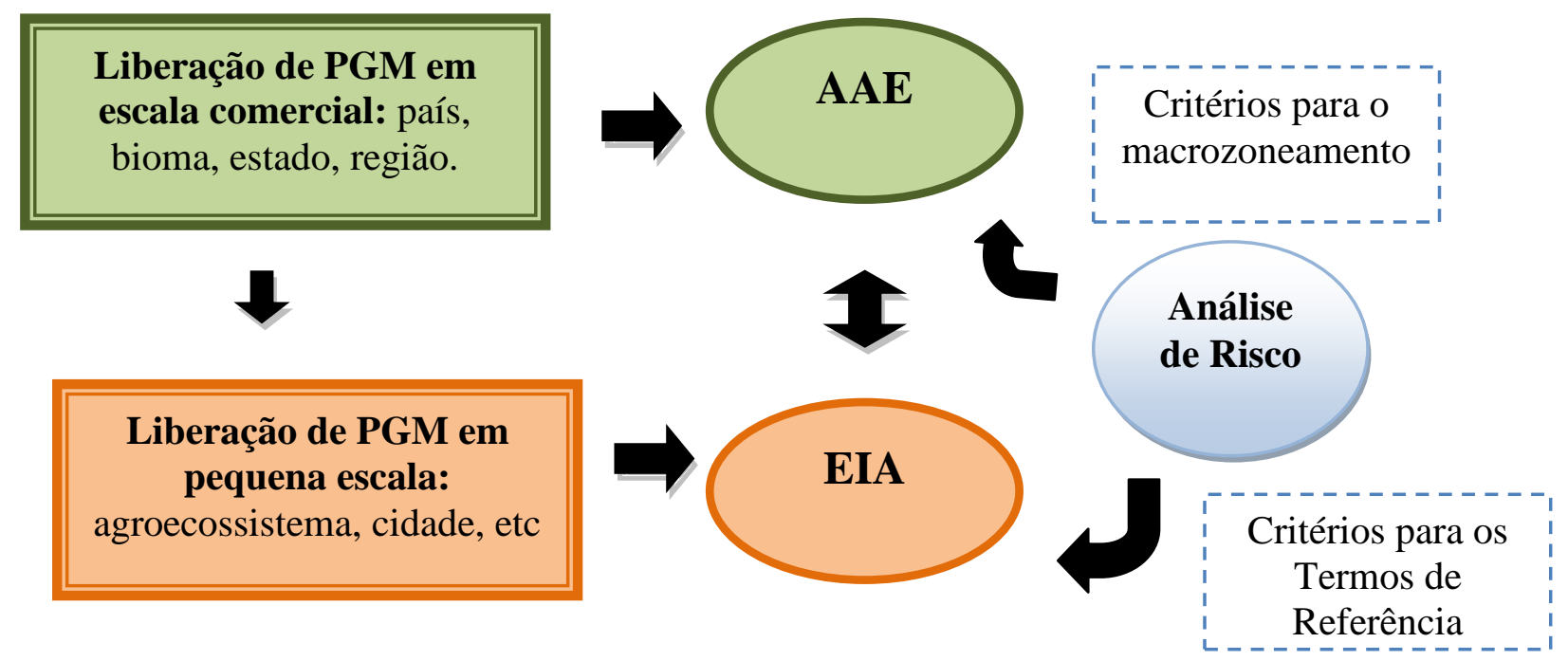

Figura 14 - Aplicações da AAE e do EIA em diferentes situações de liberação de PGMs e suas interfaces com a Análise de Risco. 


\section{CONCLUSÕES}

A questão das PGMs é um assunto bastante polêmico, em termos mundiais, devido ao elevado grau de incertezas quanto aos potenciais impactos ambientais e socioeconômicos decorrentes de sua liberação em larga escala. Neste sentido, as opiniões se dividem em torno da segurança destes organismos, partindo de premissas distintas, tais como o Princípio da Equivalência Substancial, que determina a similaridade entre as PGMs e as plantas convencionais e o Princípio da Precaução, que considera as incertezas quanto aos impactos ambientais das PGMs. Este último, quando aplicado aos OGMs, leva em conta as incertezas quanto à sua similaridade com sua contraparte convencional; à estabilidade dos genes inseridos e os potenciais impactos ambientais decorrentes, tais como: o fluxo gênico para variedades convencionais, orgânicas e selvagens; à saúde humana e aos demais animais (especialmente em relação aos genes marcadores resistentes a antibióticos); a resistência de plantas invasoras e insetos alvo; impactos negativos sobre organismos não alvo e as teias alimentares; incentivo à expansão das monoculturas; dependência do agricultor quanto à compra de sementes e das práticas agrícolas; impacto sobre a segurança alimentar, dentre outros. Principalmente por se tratar de entidades vivas que se replicam e disseminam no meio ambiente, as consequências ambientais podem ser imprevisíveis a médio e longo prazo.

Desta forma, as posições da sociedade variam entre a defesa da liberação de PGMs, de sua não comercialização e outra intermediária que, considerando as incertezas científicas a respeito da seguridade de seu uso, defendem a moratória das PGMs até que evidências científicas demonstrem sua inocuidade ao meio ambiente e à saúde.

O objetivo deste trabalho consistiu em analisar as possíveis contribuições da Avaliação Ambiental Estratégica para a tomada de decisões sobre a liberação em larga escala de PGMs e, neste sentido, investigou o sistema regulatório sobre OGMs e as práticas de governança ambiental empregadas, tais como a legitimidade das decisões, a participação social, justiça ambiental, acesso às informações ambientais e os instrumentos de predição e avaliação de impactos ambientais utilizados. Para tanto, além da revisão da literatura pertinente, foi realizada a análise de um processo de avaliação de uma PGM e aplicado um questionário abrangendo tais aspectos aos atores sociais que participam do debate sobre OGMs no Brasil, atuantes em diversas áreas de conhecimento. Com os resultados obtidos, algumas conclusões podem ser feitas, que serão apresentadas a seguir.

O Brasil possui um sistema de regulação de PGMs com concentração de poder em um órgão pertencente ao Ministério da Ciência e Tecnologia, a CTNBio o qual, pela Lei de 
Biossegurança $\mathrm{N}^{\circ} 11.105 / 05$, regulamentada pelo Decreto 5591/05, passou a ter caráter deliberativo e não apenas consultivo, como até então realizado na legislação de biossegurança anterior. Entretanto, o fato de a CTNBio ser o órgão deliberativo sobre OGMs fere os princípios constitucionais que atribuem aos órgãos do Sisnama o licenciamento de atividades potencialmente poluidoras delimitadas pelo CONAMA na Resolução No. 237/97 e Resolução No. 305/02, dentre as quais se encontra a liberação de OGMs. O licenciamento, realizado em etapas que abrangem desde a instalação à desativação dos projetos, é concedido somente se constatada a ausência ou a possível mitigação dos potenciais impactos negativos advindos da atividade em questão, dada por meio de estudos de impacto ambiental e seu respectivo relatório ambiental (EIA/RIMA) ou por outros estudos, dependendo dos requisitos em cada unidade da federação. Sobe este aspecto, a Lei de Biossegurança não possui efeito legal, o que implica a nulidade de todas as decisões tomadas até então pela CTNBio a respeito da liberação comercial de OGMs, segundo este entendimento.

O papel da CTNBio, como definido na Resolução CONAMA No.302/92, que regulamenta o licenciamento de OGMs, determina a realização de EIA/RIMA de OGMs em casos de liberação comercial e define o caráter consultivo e não deliberativo da Comissão, o que deve ser observado para garantir a constitucionalidade do processo.

A Comissão avalia os processos apresentados pelas empresas proponentes utilizando os resultados das análises de risco por elas realizados, além de considerar um reduzido número de ensaios de campo sob contenção efetuados em poucas localidades brasileiras, geralmente próximos às sedes das empresas. No exemplo da deliberação apresentada, qual seja, o algodão MON 1445, alguns pareceristas da Comissão, responsáveis por avaliar o processo, levantaram problemas de ordem metodológica da AR efetuada tais como: o fato de as análises realizadas no país considerarem praticamente o desempenho agronômico das variedades com insuficiente ponderação sobre os aspectos ambientais e sociais; o fato de os estudos não refletirem as particularidades biogeográficas brasileiras; a desconsideração de impactos cumulativos e de longo prazo; a utilização do princípio da equivalência substancial como norteador das análises; a avaliação das proteínas isoladas em testes de toxicidade e alergenicidade em detrimento do alimento por inteiro, dentre outros. Além disto, questionaram a aplicação da AR realizada em países sedes das empresas proponentes como base para a discussão e a utiização de material biliográfico condinzente com seus interesses.

No entanto, a Comissão não investigou estes aspectos cruciais para a liberação segura desta PGM no Brasil o que pode comprometer tanto no presente quanto futuramente o meio ambiente e a manutenção dos demais sistemas de cultivo de algodão praticados no país. 
Devido a todos estes fatores, pode-se concluir que no Brasil não há preocupação governamental em adotar a precaução em matéria de OGMs, já que as incertezas científicas quanto a sua aplicação segura ao meio ambiente e saúde não são incluídas nas tomadas de decisão sobre as liberações destes organismos. Uma maior atenção deveria ser dada à liberação ambiental de PGMs, pois a contaminação das variedades locais pode ocasionar sérios problemas futuros em relação à segurança alimentar da população brasileira, além de ameaçar os ecossistemas naturais e antropizados em função dos potenciais impactos ambientais em todos os níveis das teias alimentares. Além disto, a não observância da precaução nesta matéria fere o princípio constitucional do direito à livre iniciativa e ao exercício do Direito de Propriedade, pois subjuga alguns produtores rurais que são afetados pelo plantio de transgênicos como, por exemplo, produtores de alimentos orgânicos e convencionais. Uma recomendação a ser feita neste sentido é a modificação total da Lei de Biossegurança (Lei 11.105/05), de modo a se adequar aos preceitos constitucionais e das Leis, Convenções e Tratados Internacionais ratificados pelo país anteriores à sua elaboração, os quais determinam a aplicação de precaução em casos de incertezas científicas. No entanto, a maneira de implementar este princípio deve ser motivo de estudos para garantir sua eficácia. O conflito de normas não pode perdurar. Os princípios do Direito Ambiental devem se sobrepor, pois os interesses coletivos e sociais são hegemônicos frente aos interesses de grupos econômicos.

A Lei de Biossegurança de 2005 estabelece que a decisão final da CTNBio deve ter sua fundamentação resumida, explicitando as medidas de biossegurança a serem adotadas e as restrições de uso considerando as particularidades das diferentes regiões do país, a fim de subsidiar as ações dos órgãos de registro e fiscalização. No entanto, esta atribuição não foi cumprida no exemplo de PGM utilizado neste trabalho, pois tais especificidades não foram consideradas em sua liberação, uma crítica levantada tanto pelo parecerista da área Vegetal e Ambiental, Paulo Kageyama, quanto por alguns participantes da audiência pública do algodão. Portanto, nem a lei 11.105/05 é observada.

A fiscalização dos cultivos GMs é deficiente e diversos casos de contaminação de variedades orgânicas e convencionais já foram relatados, ocasionando perdas econômicas aos agricultores que optam por não cultivar PGMs, especialmente aos produtores de orgânicos. Estas ocorrências demonstram que a justiça ambiental não é praticada no país quanto a este tema.

Não há monitoramento pós-comercial de PGMs no Brasil, apesar de sua exigência na Lei de Biossegurança. Deste modo, além de infringir a Lei, o Poder Público põe em risco o 
direito constitucional dos cidadãos brasileiros a um meio ambiente sadio e uma boa qualidade de vida, já que potenciais impactos ambientais que poderiam ser mitigados ou conduzir à revisão das decisões tomadas sobre a liberação de PGMs não são detectados. Além disto, o Plano de Monitoramento apresentado pelos proponentes não é condicionante para a deliberação dos processos, o que demonstra a pouca importância que a CTNBio atribui a este mecanismo.

Diversos critérios de análise de risco nos processos de deliberação sobre PGMs são desconsiderados ou enviesados, apesar destes requisitos constarem na Lei de Biossegurança, como visto nas análises dos pareceristas da CTNBio, na audiência pública e nos relatórios finais da Comissão. Também não há definição de responsabilidades caso haja contaminação genética de material transgênico em variedades não GMs, apesar de sua vigência em diversas legislações - tais como a Lei de Crimes Ambientais - e tratados internacionais - como o Protocolo de Cartagena. Além disto, a composição da CTNBio não é representativa dos diversos setores da sociedade, como requerido, por exemplo, na Convenção da Diversidade Biológica e na Política Nacional de Biodiversidade.

A Política Nacional de Biossegurança (PNB) não se encontra implementada no país, apesar de constar na Lei de Biossegurança. Ao invés disto, o Poder Público desenvolveu uma Política Nacional de Biotecnologia, sem a participação do MMA e de ONGs ambientalistas e de outros setores, tendo por objetivo fomentar o desenvolvimento de PGMs. A isto, outros fatores, tais como a missão do MAPA em impulsionar o desenvolvimento de PGMs visando uma maior competitividade internacional, menosprezando as preocupações da sociedade ao caracterizá-las como "ideologizadas", o fato de a CTNBio considerar o caráter eminentemente técnico das avaliações de PGMs (realizadas, em sua maioria, por biotecnólogos), dente outros, evidencia o teor economicista que predomina sobre as tomadas de decisão sobre PGMs no país. A elaboração de uma PNB que considere a biotecnologia aplicada à agricultura uma questão estratégica e com profundas implicações sobre o meio ambiente e à saúde é, portanto, de extrema urgência.

O Sistema de Informações em Biossegurança não foi implantado, apesar de também constar na Lei de Biossegurança. Tal sistema permitiria uma interação entre os órgãos responsáveis pela regulação de OGMs, possibilitando à sociedade o acesso a informações sobre a fiscalização das PGMs, sobre as Leis e Normas existentes e os resultados dos monitoramentos (se fossem implementados), de maneira sistematizada. No entanto, sua ausência fere o princípio constitucional da publicidade e se configura em uma governança ambiental deficiente quanto a este aspecto. Deste modo, é indispensável que o Conselho 
Nacional de Biossegurança cumpra a lei de Biossegurança implementando o Sistema Nacional de Informações em Biossegurança.

De acordo com a nova Lei de Biossegurança, apenas para seis membros titulares da CTNBio podem ser apresentadas listas tríplices elaboradas pela sociedade civil para a nomeação por parte dos respectivos ministérios. Constata-se, desta forma, a pequena influência da sociedade civil na correlação de forças na composição do órgão superior de decisão sobre a liberação de OGMs no Brasil. Além disto, sobrepesa-se o critério de escolha baseado na titulação acadêmica, impossibilitando considerações sobre outras formas de saber e atuação dos candidatos. Na prática, um fato a ser observado na composição da CTNBio é presença majoritária de especialistas atuantes nas áreas de bioquímica, biologia molecular, genética molecular e biotecnologia, inclusive dentre os especialistas da área ambiental, além da ausência de especialistas nomeados em "agricultura familiar" e "saúde do trabalhador", que representam a sociedade civil na Comissão. A interdisciplinaridade requisitada para o tratamento adequado de um tema multifacetado como o caso dos OGMs, em razão de suas implicações sociais, ambientais e econômicas, não se faz ecoar na estrutura do órgão soberano de decisão, acarretando problemas de falta de legitimidade e confiança pública e ameaçando a integridade dos bens sociais coletivos. Neste sentido, faz-se necessária alterar a composição da CTNBio, de modo a abranger outros atores sociais interessados na questão, como cientistas sociais, filósofos especializados em ética, representantes de ONGs diversas, de ecólogos, dentre outros. Além disto, os cargos destinados às áreas Vegetal e de Meio Ambiente necessitam ser ocupados por especialistas destas áreas e não por biotecnólogos, como ocorre na grande maioria dos casos.

A participação social nas tomadas de decisão é bastante deficiente, já que as audiências públicas não são obrigatórias e, até o presente, foram efetuadas sob mandados judiciais. Além disto, a consideração sobre os posicionamentos dos participantes não são explicitados nos Relatórios Finais da CTNBio. Um momento importante para a participação dos setores interessados no processo decisório sobre OGMs seria dado com a realização destas audiências, sobrepesando-se o caráter passivo do método no tocante à influência exercida pela sociedade sobre a decisão final. Em razão de as atividades relacionadas à pesquisa, plantio e comercialização de OGMs não se encontrarem sujeitas ao processo de licenciamento ambiental, ao menos que a CTNBio solicite a realização de Estudos de Impacto Ambiental, o qual vincula o processo decisório à realização de audiências públicas, a Lei de Biossegurança confere à CTNBio a faculdade de decidir, perante solicitação de $1 / 3$ de seus membros, sobre a efetuação ou não destas audiências. 
A Instrução Normativa No. 19, de 19 de abril de 2000, que dispõe sobre os procedimentos para a realização de audiências públicas pela CTNBio, os apresenta com o objetivo instrutivo de esclarecimento à sociedade sobre os aspectos técnico-científicos relacionados à biossegurança, além de possibilitarem o debate meramente técnico-científico sobre a biossegurança de OGMs. Entretanto, a participação social é na verdade limitada, na medida em que a própria Comissão, na autoridade de seu presidente, seleciona as pessoas que solicitam realizar apresentações durante as referidas audiências. Torna-se urgente, desta forma, a ampliação da participação social de forma prévia à tomada de decisões sobre o assunto, por meio da representação dos setores sociais interessados na Comissão e da obrigatoriedade de audiências públicas, a serem realizadas caso-a-caso e não para variedades de PGMs conjuntas, como feito até então.

Além disto, cabe à Comissão considerar ou não os aspectos abordados pela sociedade civil durante as audiências e, em algumas situações, o número de seus participantes é limitado, pois os locais destinados à realização das audiências não são fixos e realizados nos anfiteatros que se encontram disponíveis no momento, com número de cadeiras que variam de acordo com a capacidade do recinto. Na audiência pública do algodão, como visto, havia uma quantidade menor de assentos do que o número de inscritos, e muitas pessoas que desejavam participar não o puderam fazer. Este modelo de audiência necessita ser reformulado.

Uma das funções da CTNBio é considerar os pareceres dos relatores de Comissões Setoriais, em se tratando da análise de processos sobre a comercialização de PGMs. No caso dos processos relativos ao algodão RR da Monsanto, diversas incertezas levantadas quanto às consequências ambientais e do conteúdo das informações concedidas pela empresa foram desconsiderados nos pleitos, que favoreceram a liberação deste transgênico. A Comissão não solicitou à empresa esclarecimentos quanto aos questionamentos levantados por alguns relatores das áreas ambiental e vegetal, mesmo em relação a casos confirmados de contaminação genética no Brasil e em outros países. Neste sentido, as normas para a análise dos processos necessitam ser modificadas, de modo a obrigar o proponente a esclarecer as dúvidas levantadas, mesmo que feitas por poucos membros da Comissão.

A desconsideração dos fatos apresentados por relatores da CTNBio, demonstrando as incertezas quanto aos potenciais impactos ocasionados pela liberação de PGMs fere o princípio da precaução e denotam pesos desmedidos dados aos relatores da Comissão durante as tomadas de decisões. Deste modo, todos os princípios de governança ambiental no tocante à gestão de PGMs no Brasil, ou seja, participação social, disposição de informações, transparência, e justiça ambiental encontram-se comprometidos ou ausentes. 
No resultado do questionário submetido, a maioria dos respondentes demonstrou insatisfação sobre a forma como são conduzidas as tomadas de decisão sobre as liberações comerciais de PGMs, abrangendo legitimidade, participação, transparência, consideração de outras PPPs, acesso às informações, dentre outros. Ficou evidente um certo desconhecimento sobre o papel dos instrumentos existentes para a avaliação de impactos de PGMs com relação aos critérios adotados (consideração de impactos cumulativos, de outras PPPs, de alternativas locacionais e tecnológicas e o monitoramento comercial), apesar de considerá-los como importantes para o processo decisório. O questionário também demonstrou uma tendência dos biotecnólogos ao tecnocentrismo, baseando-se na premissa da equivalência substancial dos OGMs com sua contraparte convencional. Por considerarem-se os especialistas mais aptos a avaliar a segurança dos OGMs, não viram a participação social como importante.

No Brasil, o único instrumento de estudo ambiental adotado nos processos decisórios envolvendo OGMs é a análise de risco, a qual, como observado, não leva em conta diversos critérios fundamentais para a identificação e avaliação de seus impactos ambientais potenciais, tanto positivos quanto negativos, tais como: os impactos cumulativos, indiretos e cumulativos; as alternativas tecnológicas, principalmente quanto a outros sistemas de cultivo; as alternativas locacionais, já que as análises não consideram as particularidades ambientais, sociais e econômicas brasileiras; a compatibilidade com as leis, Políticas, Planos e Programas relacionados e o Plano de Monitoramento pós-comercial.

O instrumento EIA/RIMA, do mesmo modo, não se mostra adequado para a avaliação de PGMs a serem liberados em larga escala, pelo fato de possuir o papel de avaliar projetos pontuais. Apesar de a legislação sobre o EIA dispor sobre o planejamento ambiental para o local em análise ao considerar suas PPPs, além dos impactos indiretos, cumulativos e de longo prazo, as alternativas tecnológicas e locacionais, tais atribuições são difíceis de concretizar, pelo fato destas atividades serem apresentadas já elaboradas às autoridades ambientais e não realizando interfaces com os demais empreendimentos em uma mesma localidade. Deste modo, apenas algumas alterações de caráter tecnológico, a fim de minimizar e/ou mitigar os potenciais impactos ambientais acabam sendo propostas para o licenciamento da atividade. No entanto, como as audiências públicas são obrigatórias no EIA, pressões da sociedade civil podem conduzir a modificações mais substanciais no projeto e mesmo a sua não aprovação. Outro ponto dificultante do instrumento é o monitoramento, que cessa após o término da atividade, o que impossibilita a identificação de impactos de longo prazo.

Ao analisar o instrumento Avaliação Ambiental Estratégica, algumas de suas características mostraram-se adequadas para a avaliação dos impactos ambientais de PGMs a 
serem liberadas em escala comercial, tais como:

- Uma PGM destinada à liberação comercial não se constitui em uma atividade pontual, pois seu cultivo abrange todo o território nacional. Apesar de os processos não denominaremse Planos ou Programas, constituem em uma ação estratégica compatível com Planos e Programas, com potencial de ocasionar impactos ambientais em larga escala, cumulativos, indiretos e de longo prazo, tanto ambientais como sociais e econômicos. Além disto, fazem parte de uma política governamental de desenvolvimento do setor agrícola, como explicitado na Estratégia Nacional de Biotecnologia e na missão do MAPA, que se relaciona com outras Leis e PPPs. Portanto, estas devem ser consideradas em qualquer processo de tomada de decisões sobre PGMs. A AAE, sendo um instrumento de planejamento ambiental, possui como atribuição a avaliação de impactos ambientais, sociais e econômicos de ações estratégicas e, portanto, tem a potencialidade de servir como instrumento de AIA para PGMs de liberação em escala comercial considerando as interfaces com outras PPPs;

- Uma das funções da AAE é a avaliação dos impactos ambientais cumulativos, indiretos e de longo prazo de PPPs, que abrangem recortes territoriais amplos. Incertezas quanto a estes impactos, amparadas em alguns casos em evidências empíricas, relacionadas às PGMs, demonstram o potencial de se utilizar a AAE para sua avaliação. Tanto as etapas de predição e avaliação de impactos quanto o monitoramento contínuo da estratégia auxiliam nestes aspectos;

- A AAE considera as alternativas de localização para a implementação de PPPs e outras ações estratégicas com o auxílio da base ambiental. Se as infomações ambientais encontrarem-se sistematizadas e, de preferência, georreferenciadas, é possível tomar decisões de teor preventivo ou precaucionista sobre a liberação ambiental de PGMs, definindo-se os locais mais adequados para tanto ou sua não liberação, dependendo da vulnerabilidade do meio;

- As alternativas tecnológicas também são contempladas na AAE, especialmente em se tratando de estratégias de desenvolvimento, como no presente caso. De acordo com as PPPs, leis e anseios da sociedade, é possível que a tomada de decisões sobre a liberação de PGMs em um determinado recorte territorial seja realizada de forma legítima e respeitando os condicionantes postos em lei. A escolha sobre os rumos da agricultura pode ser feita deste modo, considerando um horizonte de longo prazo. Por exemplo, qual o sistema de cultivo que será adotado, as adequações tecnológicas para uma coexistência entre estes, dentre outros;

- A participação social é crucial para a realização de uma AAE com legitimidade. Observou-se no questionário, na revisão da literatura e nas audiências públicas sobre PGMs 
uma necessidade de maior participação nas tomadas de decisão. A AAE tem o potencial de cumprir este papel, tal como consta na Diretiva Européia sobre AAE e no SEA Protocol, os guias mais utilizados para a criação de legislações sobre AAE no mundo. No entanto, mais estudos relacionados às formas de participação direta da sociedade organizada precisam de atenção;

- A rotina de monitoramento da ação estratégica é condicionante para uma boa prática de AAE, trazendo contribuições significativas para o tratamento do caso em questão, em função das incertezas quanto aos impactos de longo prazo decorrentes do plantio em larga escala de PGMs. Deste modo, medidas de emergência em caso de impactos significativos podem ser acionadas, de mitigação, prevenção e precaução, na medida em que novos conhecimentos vão sendo adquiridos. A revisão da ação estratégia também pode ser realizada em função do monitoramento.

Deste modo, pode-se concluir que a AAE consiste em um instrumento de AIA adequado para a tomada de decisões sobre a liberação comercial de PGMs no Brasil, estabelecendo um planejamento hierárquico que se inicie na avaliação da esperada e necessária Política Nacional de Biossegurança, seguindo dos Planos de Liberação em larga escala (para todo o território) e seus respectivos programas visando a liberação em biomas, ecorregiões ou até mesmo estados (sempre considerando as outras Leis e PPPs relacionadas à questão). As decisões tomadas nesta fase de planejamento podem auxiliar na elaboração de termos de referência para posteriores EIA/RIMAs de projetos pontuais de liberação de PGMs, fase em que estudos mais detalhados se fazem necessários. Além disto, dependendo dos estudos anteriores, é possível deliberar sobre a realização ou não de EIA e o tornar mais dinâmico, concentrando-se apenas nos aspectos mais relevantes. Dada que a elaboração da regulamentação sobre o licenciamento de OGMs ter sido realizada, os termos de referência do EIA podem também subsidiar os fatores a serem ponderados na AAE.

A Análise de Risco, constituinte do EIA sobre OGMs é importante como metodologia de identificação dos potenciais impactos, mas não como estudo conclusivo sobre as liberações de PGMs como tem sido a prática até então. No entanto, os critérios delimitados na Resolução da CTNBio de 2008 pode subsidiar a AAE e o EIA na ponderação dos fatores ambientais a serem considerados. Percebe-se, deste modo, que os três instrumentos não se excluem, sendo complementares, com a AR subsidiando tanto a AAE quanto o EIA. 


\section{REFERÊNCIAS BIBLIOGRÁFICAS}

ABRAMOVAY, R. Bem vindo ao mundo da controvérsia. In: VEIGA, J.E. (Org.). Transgênicos: sementes da discórdia. São Paulo: SENAC. p. 129-165. 2007.

ACSElRAD, H.; MELlO, C.C.A.; BEZERRA, G.N. O que é Justiça Ambiental. Rio de Janeiro: Garamond, 2009. 156p.

ALSHUWAIKHAT, H.M. Strategic environmental assessment can help solve environmental impact assessment failures in developing countries. Environmental Impact Assessment Review., 25, p. 307-313, 2005.

ALTIERI, M.; NICHOLLS, C.I. Agroecología: Teoría e práctica para una agricultura sustentable. $1^{a}$. Edição. México: PNUMA: Serie Textos Básicos para la Formación Ambiental, 2000. 43 p.

ANDRADE, P.P. Parecer ad hoc sobre o processo 01200.004487/2004-48 - solicitação de liberação comercial do Algodão Roundup Ready - Evento 1445. Brasília: Ministério da Ciência e Tecnologia, 9 jul. 2008.

ANDOW, D.A.; HILBECK, A. Science-based risk assessment for nontarget effects of transgenic crops, BioScience, vl. 54, n. 7, p. 637-649, 2004.

ANDOW, D.A.; BARROSO, P.A.V.; FONTES, E.M.G.; GOSSI-DE-SA, M.F.; HILBECK, A.; FITT, G.P. Improve the scientific basis for environmental risk assessment through the case study of Bt cotton in Brasil. Environmental Risk Assessment of Transgenic Organisms: A Case Study of Bt Cotton in Brasil. FINAL DRAFT SUBMITTED TO STAP. Cap. I, 2005. Disponível em: www.gmo-guidelines.info . Último acesso: 30 de maio de 2008.

ARAGÃO, F.J.L. Parecer Técnico sobre o processo 01200.004487/2004-48 - solicitação de liberação comercial do Algodão Roundup Ready - Evento 1445. Brasília: Ministério da Ciência e Tecnologia, 16 set. 2008.

ASLAKSEN, I; MYHR, A.I. The worth of a wildflower: Precautionary perspectives on the environmental risk of GMOs. Ecological Economics, p.1-9, 2006.

BAJAJ, S.; MOHANTY, A. Recent advances in rice biotechnology - towards genetically superior transgenic rice. Plant Biotechnology Journal, 3, p. 275-307, 2005.

BARLING, D.; DE VRIEND, H.; CORNELESE, J.A. et al. The social aspects of food biotechnology: an European view. Environmental Toxicology and Pharmacology, 7, p. 8593, 1999.

BARRAT, B.I.P.; MOEED, A; MALONE, L.A. Biosafety assessment protocols for new organisms in New Zealand: Can they apply internationally to emerging technologies? Environmental Impact Assessment Review, v.26, n.4, p. 339-358, 2006.

BARRETO, L.A. Parecer ad hoc sobre o processo 01200.004487/2004-48 - solicitação de liberação comercial do Algodão Roundup Ready - Evento 1445. Brasília: Ministério da 
Ciência e Tecnologia, 12 out. 2006.

BOCK, A. Genetically Modified Plants and Risk Analysis. In: PECHAN, P.; de VRIES, G. Genes on Menu: Facts for Knowledge-Based Decisions. UK: SPRINGER. p. 92-101. 2005.

BRASIL. Resolução CONAMA No. 001/86. Dispõe sobre critérios básicos e diretrizes gerais para o Relatório de Impacto Ambiental - RIMA. Diário Oficial da União, Brasília, DF, 17 fev. 1986.

BRASIL. Constituição (1988). Constituição da República Federativa do Brasil. Brasília, DF: Senado, 1988.

BRASIL. Resolução CONAMA No. 237/97. Dispõe sobre licenciamento ambiental; competência da União, Estados e Munícipios; listagem de atividades sujeitas ao licenciamento; Estudos Ambientais, Estudo de Impacto Ambiental e Relatório de Impacto Ambiental. Diário Oficial da União, Brasília, DF, 22 dez. 1997.

BRASIL. Decreto No.2.519, de 16 de março de 1998. Promulga a Convenção sobre Diversidade Biológica, assinada no Rio de Janeiro, em 05 de junho de 1992. Diário Oficial da União, Brasília, DF, 13 mar. 1998a.

BRASIL. Decreto No 3942, de 27 de setembro de 2001. Dá nova redação aos arts. $4^{\circ} ., 5^{\circ}, 6^{\circ}$., $7^{\circ}$., 10 e 11 do Decreto No 99274, de 6 de junho de 1990. Diário Oficial da União, Brasília, DF, 28 set. 2001.

BRASIL. Resolução CONAMA No.305, de 12 de junho de 2002. Dispõe sobre Licenciamento Ambiental, Estudo de Impacto Ambiental e Relatório de Impacto no Meio Ambiente de atividades e empreendimentos com Organismos Geneticamente Modificados e seus derivados. Diário Oficial da União, Brasília, DF, 4 jul. 2002a.

BRASIL. Decreto No.4.339, de 22 de agosto de 2002. Institui princípios e diretrizes para a implementação da Política Nacional da Biodiversidade. Diário Oficial da União, Brasília, DF, 22 ag. 2002 b.

BRASIL. Lei No. 10650, de 16 de abril de 2003. Dispõe sobre o acesso público aos dados e informações existentes nos órgãos e entidades integrantes do Sisnama. Diário Oficial da União, Brasília, DF, 17 ab. 2003a.

BRASIL. Lei No.11.105, de 24 de março de 2005. Regulamenta os incisos II, IV e V do $§ 10$ do art. 225 da Constituição Federal, estabelece normas de segurança e mecanismos de fiscalização de atividades que envolvam organismos geneticamente modificados - OGM e seus derivados, cria o Conselho Nacional de Biossegurança - CNBS, reestrutura a Comissão Técnica Nacional de Biossegurança - CTNBio, dispõe sobre a Política Nacional de Biossegurança - PNB, revoga a Lei no 8.974, de 5 de janeiro de 1995, e a Medida Provisória no 2.191-9, de 23 de agosto de 2001, e os arts. 5o, 6o, 7o, 8o, 9o, 10 e 16 da Lei no 10.814, de 15 de dezembro de 2003, e dá outras providências. Diário Oficial da União, Brasíla, DF, 28 mar. 2005. Seção 1, p.1.

BRASIL. Decreto $n^{\circ}$ 5.705, de 16 de Fevereiro de 2006. Promulga o Protocolo de Cartagena sobre Biossegurança da Convenção sobre Diversidade Biológica. Brasília, DF, 16 fev. 2006. Disponível em <http://www2.mre.gov.br/dai/m_5705_2006.htm. $>$. Acesso em: 3 set. 2006. 
BRASIL. Decreto No .6323, de 27 de dezembro de 2007. Regulamenta a Lei No. 10.831, de 23 de dezembro de 2003, que dispõe sobre a agricultura orgânica, e dá outras providências. Diário Oficial da União, Brasília, DF, 29 dez. 2007.

BROOKES, G.; BARFOOT, P. GM crops: the global socioeconomic and environmental impact - the first nine years 1996-2004. UK: PG Economics Ltd, 2005. 97 p.

BRUCE, D. Finding a balance over precaution, Journal of Agriculture and Environmental Ethics, v.15, p.7-16, 2002.

BURDGE, R. L. (1994). A conceptual approach to social impact assessment. Social Ecology Press.

BUSCH, L. The homiletics of risk, Journal of Agriculture and Environmental Ethics, v.15, p.17-29, 2002.

BUTTEL, F. The environmental and post-environmental politics of genetically modified crops and foods. Environmental Politics, v. 14, n. 3, p. 309-323, 2005.

CANADIAN BIOTECHNOLOGY ADVISORY COMMMITTEE. Improving the Regulation of Genetically Modified Foods and Other Novel Foods in Canada, p.xii, 2002. Disponível em: 〈www.cbac-cccb.ca/documents/en/cbac.report.pdf〉. Acesso em: 03 jul. 2008.

CANOTILHO, J.J.; LEITE, J.R.M. Direito Constitucional Ambiental Brasileiro. São Paulo: Saraiva, 2007. 433 p.

CARPENTER, R.A. Risk Assessment. In: VANCLAY, F.; BRONSTEIN, D. A.; Environmental and social impact assessment. New York: John Wiley \& Sons Ltd. Cap. 9, p. 193-219, 1995.

CARPENTER, J.; GIANESSI, L. Herbicide tolerant soybeans: why growers are adopting Roundup Ready varieties. AgBioForum: The Journal of Agrobiotechnology Management \& Economics, v. 2, n.2, art.2, 1999.

COCKLIN, C.; DIBDEN, J.; GIBBS, D. Competitiveness versus 'clean and green'? The regulation and governance of GMOs in Australia and the UK, Geoforum, v. 39, p. 161-173, 2008.

COLOMBO, A. G. Environmental Impact Assessment. Commission of the European Communities. Joint Research Centre. Ispra Establishment. Editora: Illustrated. 1992.

COMISSÃO TÉCNICA NACIONAL DE BIOSSEGURANÇA. Resolução Normativa No. 19, de 19 de abril de 2000. Dispõe sobre os procedimentos para a realização de audiências públicas pela Comissão Técnica Nacional de Biossegurança. Diário Oficial da União, Brasília, DF, 20 ab. 2000. Seção 1-E, p.57.

COMISSÃO TÉCNICA NACIONAL DE BIOSSEGURANÇA. Resolução Normativa No. 2, de 27 de novembro de 2006. Dispõe sobre a classificação de riscos de Organismos Geneticamente Modificados (OGM) e os níveis de biossegurança a serem aplicados nas 
atividades e projetos com OGM e seus derivados em contenção. Diário Oficial da União, Brasília, DF, 22 nov. 2006. Seção 1, p.11.

COMISSÃO TÉCNICA NACIONAL DE BIOSSEGURANÇA. Audiência Pública do Algodão Geneticamente Modificado. Brasília, DF, 17 ag. 2007.

COMISSÃO TÉCNICA NACIONAL DE BIOSSEGURANÇA. Resolução Normativa No.5, de 12 de março de 2008. Dispõe sobre normas para liberação comercial de Organismos Geneticamente Modificados e seus derivados. Diário Oficial da União, Brasília, DF, 13 mai. 2008. Seção 1, p. 6.

COMISSÃO TÉCNICA NACIONAL DE BIOSSEGURANÇA. Parecer Técnico No. 1598/2008 sobre o processo 01200.004487/2004-48 - solicitação de liberação comercial do Algodão Roundup Ready - Evento 1445. Brasília: Ministério da Ciência e Tecnologia, 2008b. 31p.

COMMONWEALTH OF AUSTRALIA. Good governance: guiding principles for implementation. Camberra: Australian Agency for International Development. p. 1-12, 2000.

COMPANHIA AMBIENTAL DO ESTADO DE SÃO PAULO. Análise de risco. São Paulo: CETESB, 2001. Disponível em: < http://www.cetesb.sp.gov.br/emergencia/riscos/apresentacao/introducao.asp $>$. Acesso em: 15 set. 2008.

CONNER, A.J.; GLARE, T.R.; NAPE, J-P. The release of genetically modified crops into the environment. Part II: Overview of ecological risk assessment, The Plant Journal, 33, p.19-46, 2003 .

DALAL-CLAYTON, B.; SADLER, B. Strategic Environmental Assessment: A Sourcebook and Reference Guide to International Experience. London: Earthscan, 2005. 470 p.

DALE, P.J.; CLARKE, B.; FONTES, E.M.G. Impacto ambiental de variedades agrícolas geneticamente modificadas. In: PIRES, C.S.S.; FONTES, E.M.G.; SUJII, E.R. (Orgs.). Impacto Ecológico de Plantas Geneticamente Modificadas. Brasília: Embrapa. p. 13-49. 2003.

DECLARAÇÃO SOBRE MEIO AMBIENTE E DESENVOLVIMENTO. Princípio 10. Rio de Janeiro, 1992.

DECLARAÇÃO SOBRE MEIO AMBIENTE E DESENVOLVIMENTO. Princípio 15. Rio de Janeiro, 1992.

DESMOND, M. Decision criteria for the identification of alternatives in strategic environmental assessment. Impact Assessment and Project Appraisal, v. 25, n. 4, p. 259269, 2007.

DEPARTMENT OF THE ENVIRONMENT, TRANSPORT AND THE REGIONS. Review of technical Guidance on Environmental Appraisal. London: Department of the Environemnt, Transporte and the Regions, 1998. 
DINON, A.Z.; MELO, J.E.; ARISI, A.C.M. Monitoring of MON810 genetically modified maize in foods in Brazil from 2005 to 2007. Journal of food Composition and Analysis, 21, 6, p. 515-518, 2008.

EGLER, P.C.G.; FILHO, S.S.A. Avaliação Ambiental Estratégica - AAE. Apostila de Curso, 2004. Sem paginação.

ELY, A. Globalization and International Governance of Modern Biotechnology: Evaluating Environmental Risks of Bt Mayze in the US and EU: Lessons and Chalenges for Kenya. Workshop on Globalisation and Governance of Modern Biotechnology, with especial reference to Kenya. Nairob, 28 de novembro de 2002.

EUROPEAN AND PARLAMENT COUNCIL. Directive 2001/18/EC. On the deliberate release into the environment of genetically modified organisms. Official Journal of The European Union, L 106:1, 2001.

ERVIN, D.E.; WELSH, R.; BATIE, S.S.; CARPENTIER, C.L. Towards na ecological systems approach in public research for environmental regulation of transgenics crops, Agriculture, Ecosystems and Environment., 99, p. 1-14, 2003.

FERREIRA, A.C.B. Carta CTNBio 929/07, de 04 de dezembro de 2007. Parecer Técnico sobre o processo 01200.004487/2004-48 - solicitação de liberação comercial do Algodão Roundup Ready - Evento 1445. Brasília: Ministério da Ciência e Tecnologia, 25 jan. 2008.

FEDERAL ENVIRONMENT AGENCY. Ecological Monitoring of Genetically Modified Organisms. Áustria: Federal Environment Agency Ltd, 2001.

FERNANDES, G.B. Chega de Manipulação. In: VEIGA, E. (Org,). Transgênicos: sementes da discórdia. São Paulo: SENAC. p. 77-125. 2007.

FLORES, S.; DAXENA, D.; STOTZKY, G. Transgenics Bt plants decompose less in soil than no-Bt plants. Soil Biology and Biochemistry, 37, p.1073-1082, 2005.

GARCIA, M.A. Alimentos transgênicos: riscos e questões éticas. Revista de Agricultura, vol.7, fasc.3, Piracicaba, 2001.

GARCIA, E. S. Epigenética: além da sequência do DNA. Jornal da Ciência, 2005. Disponível em: 〈http://www.jornaldaciencia.org.br/Detalhe.jsp?id=30541>. Acesso em: 29 abr. 2009.

GIAMPIETRO, M. The Precautionary Principle and Ecological Hazards of Genetically Modified Organisms, Ambio, v.31, n.6, p.466-470, 2002.

GLASSON, J.; THERIVEL, R.; CHADWICK, A. Introduction to environmental impact assessment. $3^{\text {a }}$.Edição. London: Spon Press, 2005. 496 p.

GLASSON, J.; SALVADOR, N.N.B. EIA in Brazil: a procedures-practice gap. A comparative study with reference to the European Union, and specially the UK, Environmental Impact Assessment Review, p. 191-225, 2000.

GRAEF, F.; SCHMIDT, G.; SCHRÖDER, W.; STACHOW, U. Determining ecoregions for 
environmental and GMO monitoring networks. Environmental Monitoring and Assessment, 108, p. 189-2003, 2005.

GREINER, R.; KONIETZNY, U. Presencen of genetically modified maize and soy in food products sold commercially in Brazil from 2000 to 2005. Food Control, 19, p. 4999-505, 2008.

GRIFFITHIS, A.J.F.; MILLER, J.H.; SUZUKI, D,T.; LEWONTIN, R.C.; GELBART, W.M. Introdução à Genética. 6a . Edição. Rio de Janeiro: GUANABARA KOOGAN SA, 1998.

GROOT, A. T.; DICKE, M. Insect-resistant transgenic plants in a multi-trophic context. The Plant Journal, vol. 31, 4, p. 387-406, 2002.

GROSSI DE SÁ, M.F.; ROMANO, E. Genética molecular de plantas para resistência a insetos. In: PIRES, C.S.S.; FONTES, E.M.G.; SUJII, E.R. (Orgs.). Impacto Ecológico de Plantas Geneticamente Modificadas. Brasília: Embrapa, 2003. p.49-65.

GUEHLSTORF, N.P.; HALLSTROM, L.K. The role of culture in risk regulations: a comparative case study of genetically modified corn in the United States os America and European Union. Environmental Science and Policy. 8, p. 327-342. 2005.

GUIVANT, J.S. A governança dos riscos e os desafios para a redefinição da arena pública no Brasil. In: CGEE; FAPESP; EMBRAPA; UFSC. Ciência, Tecnologia e Sociedade: Novos Modelos de Governança. Brasília: CGEE, p. 47-86, 2005.

GUIVANT, J. S. Transgênicos e percepção pública da ciência no Brasil. Ambiente e Sociedade, v.9, 1, p. 1-30, 2006.

GUJAR, G.T., NAIR, R.; KUMARI, A; KALIA, V. Toxicity to the cotton bollworm, Helicoverpa armigerada, of some Cry1Ac toxins expressed in cotton in Índia. Crop Protection, vol. 27, 3-5, p.537-544, 2008.

GUPTA, J., van der ZAAG, P. Interbasin water transfers and integrated water resources management: Where engineering, science and politics interlock. Physics and Chemistry of the Earth,33.p.28-40, 2008.

HANUSCH, M.; GLASSON, J. Much ado about SEA/SA monitoring: The performance of English Regional Spatial Strategies, and some Germany comparisons, Environmental Impact Assessment Review, 28, p.601-617, 2008.

HARWOOD, J.D.; WALLIN, W.; OBRYCKI, J.J. Uptake of Bt endotoxins by nontarget herbivores and higher order arthropod predators: molecular evidence from a transgenic corn agroecosystem. Molecular Ecology, 14, p. 2815-2823, 2005.

HELGREN, K.; PEACOCK, J.; FINNEGAN, D., SPROW, S.; KING, B. Genetically Modified Foods: Consumer Views and Regulations Around the World. http://www.calpoly.edu/ nmacdoug/AGB31801_00_04/AGB31801_Index.html. Acesso em: 25 set. 2008 .

HENRY, C. Cumulative long-term effects of genetically modified (GM) crops on human/animal health and the environment: risk assessment methodology. UK: Central 
Science Laboratory, 2006. 236 p. Relatório Final, No 07-0402/2005/414455/Mar/B4.

HILBECK, A. Implications of transgenic, insecticidal plants for insect and plant biodiversity. Perspectives in Plant Ecology, Evolution and Systematics, vol.4, 1, p. 43-61, 2001.

HINDMARSH, R. The need for effective assessment: sustainable development and the social impacts of biotechnology in the third world. Environ. Impact Assess. Rev., 10, p. 195-208, 1990.

HO, M-W.; CHING, L.L. The case for a GM-Free Sustanable World: Independent Science Panel. London: Institute of Science in Society; Malaysia: Third World Network, 2003. 115p.

ICOZ, I.; STOTZKY. Fate and effects of insect-resistant Bt crops in soil ecosystems. Soil Biology and Biochemistry, vol.40, 3, p. 559-586, 2008.

INSTITUTE FOR GLOBAL ENVIRONMENTAL STRATEGIES. Report of the First Phase Strategic Research: Environmental Governance. IGES, 2001.

INSTITUTO SOCIOAMBIENTAL. Política de Desenvolvimento da Bioindústria: para quem? Notícias Socioambientais, 25 de julho de 2006. Disponível em: <http://www.socioambiental.org/nsa/detalhe?id=2286>. Último acesso: 10 set. 2008.

INTERNATIONAL ASSOCIATION FOR IMPACT ASSESSMENT. Biodiversity in Impact Assessment. Special Publication Series, n. 3, p. 1-4, 2005.

INTERNATIONAL SERVICE FOR THE ACQUISION OF AGRI-BIOTECH APPLICATIONS. ISAAA Briefs 39-2008: Global Status of Commercialized Biotech/GM Crops: 2008: The First Thirteen Years, 1996 to 1998. Disponível em: <http://www.isaaa.org>. Acesso em: 20 set. 2009.

IRWIN, A.; HORST, M. Science, Technology and Governance in Europe: lessons from the STAGE process. Ciência, Tecnologia e Sociedade: Novos Modelos de Governança. Brasília: CGEE, p. 15-46, 2005.

IVES, A. R.; ANDOW, D.A. Evolution of resistence to Bt crops: direction selection in structured environments. Ecology Letters. 5, p. 792-801, 2002.

JAMES, C. 2008 ISAAA Report on Global Status of Biotech/GM Crops. International Service for Acquisition of Agri-biotech Applications. Disponível em: 〈http:www.isaaa.org>. Acesso em: 20 set. 2009.

JESUS, K.R.E.; PLONSKI, G.A (Eds.). Biotecnologia e Biossegurança: Integração e Oportunidades no Mercosul. Brasília, DF: Embrapa Informação Tecnológica, 2006. 439p.

JOÃO, E. Key Principles of SEA. In: SCHMIDT, M.; JOÃO, E.; ALBRECHT, E. (Eds.). Implementing Strategic Environmental Assessment. UK: Springer, p. 3-13. 2005.

JONES, C.; BAKER, M.; CARTER, J.; JAY, S.; SHORT, M.; WOOD, C. Strategic Environmental Assessment and Land Use Planning: An International Evaluation. UK: Earthscan. 2005. 300 p. 
KAGEYAMA, P. Parecer ad hoc sobre o processo 01200.004487/2004-48 - solicitação de liberação comercial do Algodão Roundup Ready - Evento 1445. Brasília: Ministério da Ciência e Tecnologia, 2008.

KARAM, D. Parecer ad hoc sobre o processo 01200.004487/2004-48 - solicitação de liberação comercial do Algodão Roundup Ready - Evento 1445. Brasília: Ministério da Ciência e Tecnologia, 18 jun. 2008.

KELLY, B.G.; VESPERMANN, A.; BOLTON, D.J. Gene transfer events and their occurence in select environments. Food and Chemical Toxicology, 47, p. 978-983, 2009.

KINGSBURY, D.T. Regulation of Biotechnology in the United States: one in a half years of using the 'Coordinated Famework', TREE, v.3, 4, 1988.

KIRCHHOFF, D. Avaliação de risco ambiental e o processo de licenciamento: o caso do gasoduto de distribuição gás brasiliano trecho São Carlos - Porto Ferreira. 2004. Dissertação (Mestrado em em Ciências da Engenharia Ambiental). Escola de Engenharia de São Carlos, Universidade de São Paulo, São Carlos, 2004.

KORMOS, C.; HUGHES, L. Regulating Genetically Modified Organisms: Strinking a Balance Between Progress and Safety. Center for Applied Biodiversity Science. Conservation International: Washington, 2000.

KUMAR, V.; BELLINDER, R.R.; BRAINARD, R.K.; GUPTA, R.K. Risks of herbicideresistance rice in Índia: A review. Crop Protection, vol.27, 3-5, p.320-329, 2008.

KUITUNEN, M.; JALAVA, K.; HIRVONEN, K. Testing the usability of the Rapid Assessment Matrix (RIAM) method for comparison of EIA and SEA results. Environmental Impact Assessment Review, v. 28, 4-5, p. 312-320, 2007.

LEE, D.; NATESAN, E. Evaluating genetic containment strategies for transgenic plants. Trends in Biotecnology, v. 24, n. 3, p. 109-114, 2006.

LEKNES, E. The roles of EIA in the decision-making process. Environmental Impact Asessment Review, 21, p. 309-334. 2001.

LEVIDOW, L. European public participation as risk governance: enhancing democratic accountability for agbiotech policy? East Asian Science, Technology and Society (EASTS): an International Journal, v.1, n.1, p.19-51, 2007.

LEVIDOW, L.; BOSCHERT, K. Coexistence or contradiction? GM crops versus alternative agriculturesin Europe, Geoforum, v.39, n. 1, p.174-190. 2008.

LIANG, GE-MEI; KONG-MINGU, W.;HONG-KUN, Y.; LI, KE-KE; FENG, X.; YUYUAN,G. Changes of inheritance mode and fitness in Helicoverpa armigerada (Hübner) (Lepidoptera: Noctuidae) along with its resistance evolution to Cry1Ac toxin. Journal of Invertebrate Pathology, v.97, 2, p.142-149, 2008.

LIMA, M.B. Documento apresentado à Secretaria Executiva da CTNBio referente à audiência pública sobre o milho transgênico. Ministério Público Federal. 2007. 
LINACRE, N.A.; GASKELL, J.; ROSEGRANT, M.W.; FALK-ZEPEDA, J.; QUEMADA, H.; HALSEY, M.; BIRNER, R. Strategic Environmental Assessment: Assessing the Environmental Impacto of Biotecnology, International Food Policy Research Institute, Washington, DC, 2005.

LUIZ, J. Parecer Técnico sobre o processo 01200.004487/2004-48 - solicitação de liberação comercial do Algodão Roundup Ready - Evento 1445. Brasília: Ministério da Ciência e Tecnologia, 2008. 13 p.

MACMILLAN, T. Tales of power in biotechnology regulation: the EU ban on BST. Geoforum, 34, p. 187-201, 2003.

MARIN, V.A. Parecer Técnico sobre o processo 01200.004487/2004-48 - solicitação de liberação comercial do Algodão Roundup Ready - Evento 1445. Brasília: Ministério da Ciência e Tecnologia, 2008. 5 p.

MAYER, S.; STIRLING, A. Finding a precautionary approach to technological developments lessons for the evaluation of GM crops, Journal of Agriculture and Environmental Ethics, v. 14, p.57-71, 2002.

MEEK, S.; KEESE, P. Putting theory into practice - applying risk analysis to the regulation of GMOs. Canberra, Austrália: Office of the Gene Technology Regulator, sem data.

MENOSSI, M. Parecer ad hoc sobre o processo 01200.004487/2004-48 - solicitação de liberação comercial do Algodão Roundup Ready - Evento 1445. Brasília: Ministério da Ciência e Tecnologia, 12 mai. 2007.

MESSÉAN, A.; SAUSSE, C.; GASQUEZ, J.; DARMENCY, H. Ocurrence of genetically modified oilseed rape seeds in the harvest os subsequent conventional oilseed rape over time. European Journal of Agronomy, v.27, n.1, p. 115-122, 2007.

MILARÉ, E. Direito do Ambiente: A Gestão Ambiental em Foco. São Paulo: Editora Revista dos Tribunais, 5a. Ed., 1280 p., 2007.

MILLSTONE, E.; BRUNNER, E.; MAYER, S. Beyond 'substancial equivalence', Nature, v. 401, p. 525-526, 1999.

MIDDELHOFF, U.; REICHE, E-W; WINDHORST. An integrative methodology to predict dispersal of genetically modified genotypes in oilseed rape at landscape level - A study for the region of Schleswig-Holstein, Germany. Ecological Indicators, 485, p.1-8. 2009.

MINARÉ, R. Onde está o Sistema de Informações em Biossegurança - SIB?, 2008. Disponível em: $<$ http://www.portaldoagronegocio.com.br/com.br $>$. Acesso em: 15 Jun. de 2008.

MINISTÉRIO DA AGRICULTURA, PECUÁRIA E ABASTECIMENTO. Novos tempos: A agropecuária no Brasil 2003-2006. Brasília: Editora Gazeta Santa Cruz. 2006. Disponível em: http://www.agricultura.gov.br. Acesso em: 10 Jun. 2008. 
MINISTÉRIO DO DESENVOLVIMENTO, INDÚSTRIA E COMÉRCIO EXTERIOR. Estratégia Nacional de Biotecnologia: Política de Desenvolvimento da Bioindústria. Brasília: Fórum de Competitividade de Biotecnologia, 2006. 59 p.

MINISTÉRIO DO MEIO AMBIENTE. Agenda 21 Brasileira: ações prioritárias. 6 ${ }^{a}$. Edição. Brasília: Comissão de Políticas de Desenvolvimento Sustentável e da Agenda 21 Nacional, 2004. $158 \mathrm{p}$.

MINISTÉRIO PÚBLICO FEDERAL. Organismos Geneticamente Modificados, Período 1998 a 2007. Informações Técnicas e Notas Técnicas Cadastradas no Acervo da $4^{\text {a }}$ CCR. 2007. Disponível em <http://4ccr.pgr.mpf.gov.br/institucional/grupos-de-trabalho/gttransgenicos/informacoes_tecnicas/informacoes-tecnicas/>. Acesso em: 30 set. 2007.

MINISTRY FOR THE ENVIRONMENT. Genetic modification regulation, 2007. Disponível em: < http://www.mfe.govt.nz/issues/organisms/regulation/index.html >. Acesso em: 20 set. 2009.

MOHAMMED-AWEL, J.; KOPECKYK.; RINGLAND, J. A situation in which a local nontoxic refuge promotes pest resistance to toxic crops. Theoretical Population Biology, vol.71, p.131-146, 2007.

MOORE, E. Food Safety, Labelling, an the Role of Science:Regulating Genetically Engineered Food Crops in Canada and the United States. In: WORKSHOP ON THE POLITICS OF FOOD, 2000, Copenhagen. Paper for the ECPR Joint Sessions. Copenhagen, 2002, p 1-34.

MYHR, A.I., TRAAVIK, T. The precautionary principle: scientific uncertainty and ommited research in the context of GMO use and release. Journal of Agricultural and Environmental Ethics, 15, p. 73-86, 2002.

NAJAM, A., PAPA, M., TAIYAB, N. Global Environmental Governance: A Reform Agenda. International Institute for Sustainable Development, 2006. 114 p.

NASSAR, N.; FERNANDES, G. Raciocínio científico e critérios justos em falta nos julgamentos da CTNBio. Jornal da Ciência (Órgão da Sociedade Brasileira para o Progresso da Ciência), 2007. Disponível em: http://www.jornaldaciencia.org.br/Detalhe.jsp?id=45767. Acesso em: 05 jan. 2008.

NATIONAL AGRICULTURAL STATISTICS SERVICE. Acreage. USDA. 2009. Disponível em: < http://www.ers.usda.gov/data/biotechcrops/ExtentofAdoptionTable1.htm>. Acesso em: 05 jan. 2010.

NATIONAL RESEARCH COUNCIL. Understanding Risks: Informing Decisions in a Democratic Society. Stern, P.C.; Fineberg, H.V. (Organizadores). Washington, DC: National Academy Press, 1996. 249p. Disponível em:〈www.nap.edu/catalog/5138.html $>$. Acesso em: 02 ab. 2009.

NATIONAL RESEARCH COUNCIL. Environmental effects of transgenic plants: The scope and adequacy of regulation. Washington, DC: National Academy Press, 2002. 342p. Disponível em: 〈www.nap.edu/catalog/10258.html〉. Acesso em: 10 jun. 2007. 
NELSON, K.C.; BANKER, M.J. Problem Formulation and Options Assessment Handbook: A guide to the PFOA process and how to integrate it into environmental risk assessment (ERA) of genetically modified organisms (GMOs). GMO ERA Project, 2007. 237p. Disponível em: <http://www.gmoera.umn.edu >. Acesso em: 15 jun. 2007.

NIBOUCHE, S.; GUÉRARD, N.; MARTIN, P.; VAISSAYRE, M. Modelling the role of refugies for sustainable management of dua-gene $\mathrm{Bt}$ cotton in West African smallholder farming systems. Crop Protection, vol.26, 6, p.828-836, 2007.

NILSSON, M.; DALKMANN. H. Decision-making and strategic environmental assessment, Jornal of Environmental Assessment Policy and Management, v. 3, n. 3, p. 305-327, 2001.

NODARI, R.; GUERRA, M.P.; VALLE, S. Política Nacional de Biossegurança, Jus Navigandi, ano 6, 56, 2002. Disponível em: <http://jus2.uol.com.br/doutrina/texto.asp?id=2880>. Acesso em: 22 jan. 2009.

NUSDEO, A. M. Justiça Ambiental, 2006. Disponível em: <http://www. >. Acesso em: 08 jan. 2008.

O'CONNOR, M., VAN DEN HOVE. Prospects for public participation on nuclear risks and policy options: innovations in governance practices for sustainable development in the European Union, Journal of Hazardous Materials, 86, p. 77-99, 2001.

ODA, L.M. Análise comparativa dos Modelos Regulatórios para a Tecnologia do DNA Recombinante no mundo e a Legislação Brasileira de Biossegurança, Jornal da ANBio, Ano 3, $11,2003$.

OFFICE OF THE GENE TECHNOLOGY REGULATOR. Risk Analysis Framework. Austrália: Commonwealth of Australia, 2005. 106 p. Disponível em: < http://www.ogtr.gov.au/internet/ogtr/publishing.nsf/Content/raf-3/\$FILE/raffinal2.2.pdf>.

Acesso em: 03 ag. 2008.

OLIVEIRA, I.D. Alternativas para a implementação da Avaliação Ambiental Estratégica no Brasil. 2008. Tese (Doutorado em Ciências da Engenharia Ambiental). Escola de Engenharia de São Carlos, Universidade de São Paulo, São Carlos, 2008.

PALEOTTI, C.; FlAMM, E; YAN, W.; MEEK, S.; RENCKENS, S.; FELLOUS, M.; KUIPER, H. GMO risk assessment around the world: some examples. Trends in Food Science \& Technology, 19. p. 70-78, 2008.

PARTIDÁRIO, M.R. Avaliação Ambiental Estratégica. Brasília: MMA/SQA, 2002. 91 p.

PARTDÁRIO, M.R.. Guia de boas práticas para Avaliação Ambiental Estratégica: orientações metodológicas. Portugal: Agência Portuguesa do Ambiente. 2007.

PELAEZ, V.; SCHIMIDIT, W. A difusão dos OGMs no Brasil: imposição e resistências, Estudos Sociedade e Agricultura, 14, abril, p.5-31, 2000.

PELAEZ, V. Biopoder e regulação da tecnologia: o caráter normativo da análise de risco dos OGMs, Ambiente e Sociedade, VII, 2, p.145-158, 2004. 
PELAEZ, V. O Estado de Exceção no Marco Regulatório dos Organismos Geneticamente Modificados no Brasil. In: XLV Congresso da Sociedade Brasileira de Economia, Administração e Sociologia Rural. Londrina. Conhecimentos para a Agricultura do Futuro. Universidade Estadual de Londrina, 2007. 20 p.

PELAEZ, V.; SBICCA, A. Organismos Geneticamente Modificados: a face não revelada pela ciência. Sem data. Disponível em: 〈br.geocities.com/adsbicca/textos/AV111102.pdf〉. Último acesso: 20 de maio de 2007.

PELLETIER, D.L. FDA's regulation of genetic engeneered food: Scientific, legal and political dimensions. Food Policy, 31, p.570-590, 2006.

PEROZZI, M. Política para biondústria desconsidera aspectos socioambientais. ComCiência: $\begin{array}{lllll}\text { Revista Eletrônica de Jornalismo Científico. } & \text { 03/08/2006. }\end{array}$ http://www.comciencia.br/comciencia/handler.php?section=3\&noticia=161. Último acesso: 2 de maio de 2007.

PESSÔA, L.T.G. Metodologia de Avaliação Ambiental Estratégica de Organismo Geneticamente Modificado na Agricultura. 2007. 265 f. Tese (Doutorado em Ciências) Universidade Federal do Rio de Janeiro, Rio de Janeiro, 2007.

PETKOVA, E., MAURE, C., HENNINGER, N., IRWIN, F. Closing the gap: Information, participation, and justice in decision-making. World Resources Institute, 2002.

PURICELLI, E.; TUESCA, D. Weed density and diversity under glyphosate-resistant crop sequences, Crop Protection, 24, 6, p.533-542, 2005.

RAYBOLD, A. Ecological versus ecotoxicological methods for assessing the environmental risks of transgenic crops, Plant Science, 173, p.589-602, 2007.

RIBOT, J. C. La Descentralización Democrática de Los Recursos Naturales: La Institucionalización de la Participación Popular. World Resources Institute. 2002.

ROBIN, M-M. O Mundo Segundo a Monsanto: Da dioxina aos transgênicos, uma multinacional que quer o seu bem. São Paulo: Radical Livros, 2008. 370p.

SAEGLITZ, C.; BARTSCH, D. Regulatory and associated political issues with respect to Bt transgenic maize in the European Union, Journal of Invertebrate Pathology, 83, p.87-109, 2003.

SÁNCHEZ, L.E. Avaliação de Impacto Ambiental: conceitos e métodos. São Paulo: Oficina de Textos. 2006. 495 p.

SANDERMANN, H. Plant biotechnology: ecological case studies on herbicide resistance. Trends in Plant Science, vol.11, 7, p. 324- 329, 2006.

SANTOS, R.F. Planejamento Ambiental: teoria e prática. São Paulo: Oficina de Textos, 2004. $184 \mathrm{p}$.

SCHMIDT, M.; JOÃO, E.; ALBRECHT, E. Implementing Strategic Environmental 
Assessment. Heidelberg: Springer Berlin. 2005. 742 p.

SILVEIRA, J.M.; BUAINAN, A.M. Aceitar riscos controlados para inovar e vencer desafios. In: VEIGA, E. (Org,). Transgênicos: sementes da discórdia. São Paulo: SENAC, 2007. p. 2373.

SNOW, A.A.; ANDOW, D.A.; GEPTS, P.; HALLERMAN, E.M.; POWER, A.; TIEDJE, J.M.; WOLFENBARGER, L.L. Genetically Engineered Organisms and the Environment: current status and recomendations, Ecological Applications, v.15, n.2, p. 377-404, 2005.

SOUZA, M. P. Fundamentos de Gestão Ambiental: princípios e prática. 1a . Edição. São Carlos: Riani Costa, v. 1, 2000. 108p.

SOUZA, M.P. A base de referência e a avaliação de impacto ambiental. Anais $1^{\circ}$ Simpósio de Geotecnologias no Pantanal, Campo Grande, Brasil, 11-15 de novembro de 2006, Embrapa Informática Agropecuária/INPE, p. 749-756. 2006.

STIRLING, A. A precautionary approach to technological appraisal? A multicriteria mapping of genetic modification in UK agriculture. TA-Datenbank Nachrichten, v. 3, n. 9, p.39-51, 2000.

STIRLING, A. On Science and Precaution in the management of technological Risk: A Synthesis Report of case studies. Sevilha: European Commission and Institute Prospective Technological Studies, V. 1, 1999. 56 p.

TAPPESER, B. Biotechnology, Food, Agriculture, Public policy and Consumer concerns. Phytosfere'99. In: DE VRIES, G.E.; METZLAFF, K. (Orgs.). Highlights in European Plant Biotechnology. 1999.

THE CENTER FOR FOOD SAFETY. Animal and Plant Health Inspection Service's Draft Programmatic Environmental Impact Assessment for the Introduction of Genetically Engineered Organisms. Riverdale, 2007.

THERIVEL, R. Strategic Environmental Assessment in Action. London, UK: Earthscan Publications Limited, 2004. 276 p.

THERIVEL, R.; WILSON, E.; THOMPSON, S.; HEANEY, D.; PRITCHARD, D. Strategic environmental assessment. London, UK: Publications Limited, 1994. 132 p.

THUSWOHL, M. Justiça volta a proibir que CTNBio libere milho transgênico. Associação Civil Aternativa Terrazul. 2007. Disponível em: <http:// www.terrazul.m2014.net/spip.php?article>. Acesso em: 04 mai. 2008.

TOMMASI, L.R. Estudo de impacto ambiental. $1^{\text {a }}$. Edição. São Paulo: CETESB: Terragraph Artes e Informática S/C Ltda, 1994. 354p.

UNIÃO EUROPÉIA. Diretiva 2001/42/CE do Parlamento Europeu e do Conselho Relativa à Avaliação dos efeitos de determinados Planos e Programas no Ambiente. C5-0118/2001, LEX 271, Luxemburgo, 27 jun. 2001. 
UNITED NATIONS ENVIRONMENTAL PROGRAMME. UNEP International Technical Guidelines for Safety in Biotechnology. Nairobi, Kênya: UNEP. 1995.

UNITED NATIONS ENVIRONMENTAL PROGRAMME. Environmental Impact Assessment and Strategic Environmental Assessment: Towards an Integrated Approach. Genebra, Suíça: UNEP. 2004. Disponível em < http://www.unep.ch/etu/publications/textONUBr.pdf>. Acesso em: 30 set.2008.

UNION OF CONCERNED SCIENTISTS. Gone to seed: Transgenic contaminants in the traditional food supply. UCS Publication, Cambridge. 2004. Disponível em: http://www.ucsusa.org. Último acesso: 24 de fevereiro de 2008.

UNION OF CONCERNED SCIENTISTS (UCS). Risks of genetic engineering. 2007. Disponível em: <http://www.ucsusa.org/food_and_environment/genetic_engineering/risks-ofgenetic_engineering.html\#1_Potential_Harms_to_Health. Último acesso: 24 de fevereiro de 2008 .

US ENVIRONMENTAL PROTECTION AGENCY. Risk Assessment Portal: Basic $\begin{array}{lccl}\text { Information. } & 2008 . & \text { Disponível } & \text { em: } \\ \text { http://www.epa.gov/riskassessment/basicinformation.htm\#risk>. } & \text { Acesso em: } 02 \text { ab. } 2008 .\end{array}$

VAN DEN BELT, H.; GREMMEN, B. Between precautionary principle and "sound science": distributing the burdens of proof, Journal of Agriculture and Environmental Ethics, v.15, p103-122, 2002.

VARZAKAS, T.H.; CHRYSSOCHOIDS, G.; ARGYROPOULOS, D. Approaches in the risk assessment of genetic modified foods by the Hellenic Food Safety Authority, Food and Chemical Toxicology, 45, p.530-542, 2007.

VEIGA, J.E. Introdução. In: VEIGA, J.E. (Org.). Transgênicos: sementes da discórdia. São Paulo: SENAC, 2007. p. 9-23.

VERCESI, A.E. Parecer Técnico sobre o processo 01200.004487/2004-48 - solicitação de liberação comercial do Algodão Roundup Ready - Evento 1445. Brasília: Ministério da Ciência e Tecnologia, 19 jun. 2007.

WALES, C.; MYTHEN, G. Risky Discourses: The Politics of GM Foods. Environmental Politics, v. 11, n.2, p.121-144, 2002.

WATKINSON, A.R.; FRECKLETON, R.P.; ROBINSON, R.A.; SUTHERLAND, W.J. Predictions of biodiversity response to genetically modified herbicide-tolerant crops. Science, 289, p.1554, 2000.

WOOD, G.; GLASSON.; BECKER, J. EIA scoping in England and Wales: Practitioner approaches, perspectives and constraints. Environmental Impact Assessment Review, p. 1$21,2005$.

WOSSINK, A.; DENAUX, Z.S. Environmental and cost efficiency of pesticide used in transgenic and conventional cotton production. Agricultural Systems, 90 p. 312-328, 2006. 
ZAMBOLIM, L. Parecer Técnico sobre o processo 01200.004487/2004-48 - solicitação de liberação comercial do Algodão Roundup Ready - Evento 1445. Brasília: Ministério da Ciência e Tecnologia, 14 ag. 2008.

ZAPIOLA, M.L.; CAMPBELL, C.K.; BUTLER, M.D.MALLORY-SMITH, C.A. Escape and stablishment of transgenic glyphosate-resistance creeping bentgrass Agrostis stolonifera in Oregon, USA: a 4-year study. Journal of Applied Ecology, 45, p.486-494, 2008. 


\section{ANEXO}

\section{As contribuições para a tomada de decisões sobre Plantas Geneticamente Modificadas no Brasil}

Você está recebendo o Questionário referente ao trabalho de doutorado da bióloga Denise Gallo Pizella, sob orientação do Prof. Marcelo Pereira de Souza, intitulado "As contribuições da Avaliação Ambiental Estratégica para a tomada de decisões sobre Plantas Geneticamente Modificadas no Brasil". A tese está sendo desenvolvida no Centro de Recursos Hídricos e Ecologia Aplicada da Escola de Engenharia de São Carlos, Universidade de São Paulo, com o financiamento da CAPES.

Para o correto entendimento das questões, cabem as seguintes observações:

As questões se referem especificamente às Plantas Geneticamente Modificadas (PGMs) de aplicação agrícola excluindo-se, deste modo, outras categorias de Organismos Geneticamente Modificados (OGMs), como fármacos, microorganismos e animais.

Para a presente pesquisa, apenas as PGMs destinadas à liberacão comercial serão consideradas, o que exclui as liberações para fins de pesquisa.

Após o recebimento das respostas, no prazo de três semanas contadas a partir da data de envio do questionário, a coordenação efetuará a tabulação e a análise das respostas, que serão apresentadas ao grupo de participantes. As respostas serão analisadas em conjunto de maneira anônima.

Apresentando quaisquer dúvidas ou opiniões acerca do questionário, contacte, por gentileza, os responsáveis pelo trabalho por meio dos seguintes endereços eletrônicos: denisegallo@usp.br (Denise Gallo Pizella) e mps@sc.usp.br (Prof. Marcelo Pereira de Souza). Deixe seu telefone e nós entraremos em contato.

Agradecemos imensamente sua participação. 


\section{QUESTIONÁRIO:}

\section{Qual sua área de atuação?}

( ) Biotecnologia

( ) Biossegurança

( ) Ecologia (incluindo Agroecologia)

( ) Meio Ambiente (planejamento, avaliação de impactos ambientais e outros)

( ) $\mathrm{ONG}$

( ) Outro:

2. Em relação à liberação do plantio em escala comercial de PGMs, qual das alternativas expressa melhor sua opinião:

( ) Devem ser considerados os interesses e objetivos das Políticas do setor agrícola, do setor econômico, as questões fundiárias, a política ambiental da região, Estado ou País.

(...) Não devem ou não precisam ser considerados os interesses e objetivos das Políticas do setor agrícola, do setor econômico, as questões fundiárias, a política ambiental da região, Estado ou País.

( ) Se tiver outra opinião, especifique-a:

3. Em um processo de avaliação ambiental para a liberação de plantio comercial de PGMs, qual a importância de se considerar:

( 1 = irrelevante e 4 = muito importante)

a) Os impactos ambientais cumulativos:

\begin{tabular}{|l|l|l|l|l|l|}
\hline & $\mathbf{1}$ & $\mathbf{2}$ & $\mathbf{3}$ & $\mathbf{4}$ & \\
\hline Irrelevante & & & & & Muito importante \\
\hline
\end{tabular}

b) O posicionamento dos agentes sociais afetados pela decisão:

\begin{tabular}{|l|l|l|l|l|l|}
\hline & $\mathbf{1}$ & $\mathbf{2}$ & $\mathbf{3}$ & $\mathbf{4}$ & \\
\hline Irrelevante & & & & & Muito importante \\
\hline
\end{tabular}


4. Indique quais os seguintes segmentos da sociedade que devem participar do processo decisório envolvendo a liberação ambiental de PGMs, além das autoridades competentes?

\section{(Pode ser escolhida mais de uma alternativa)}

( ) especialistas na área de biotecnologia

( ) especialistas na área de biossegurança

( ) especialistas na área de ecologia

( ) especialistas na área de meio ambiente

( ) especialistas na área de saúde

( ) produtores agrícolas

( ) consumidores

( ) ambientalistas

Outros:

5. Em um processo de avaliação ambiental para a liberação comercial de PGMs, qual a importância de se considerar:

$$
(1=\text { irrelevante e } 4=\text { muito importante })
$$

a-) a agricultura orgânica e convencional como alternativas a tecnologia transgênica:

\begin{tabular}{|l|l|l|l|l|l|}
\hline & $\mathbf{1}$ & $\mathbf{2}$ & $\mathbf{3}$ & $\mathbf{4}$ & \\
\hline Irrelevante & & & & & Muito importante \\
\hline
\end{tabular}

b-) uma análise conjunta das Políticas, Planos e Programas intersetoriais (ambientais, econômicos, agrícolas, fundiários, tecnológicos e outros) que tenham relação com a proposta de liberação de plantio em escala comercial do transgênico.

\begin{tabular}{|l|l|l|l|l|l|}
\hline & $\mathbf{1}$ & $\mathbf{2}$ & $\mathbf{3}$ & $\mathbf{4}$ & \\
\hline Irrelevante & & & & & Muito importante \\
\hline
\end{tabular}

c-) as alternativas locacionais (estudo de localização) para o plantio em escala comercial do transgênico: 


\begin{tabular}{|l|l|l|l|l|l|}
\hline & 1 & 2 & 3 & 4 & \\
\hline Irrelevante & & & & & Muito importante \\
\hline
\end{tabular}

c-) o plano de monitoramento pós-comercial (após a liberação para o plantio comercial) proposto para a PGM:

\begin{tabular}{|l|l|l|l|l|l|}
\hline & $\mathbf{1}$ & $\mathbf{2}$ & $\mathbf{3}$ & $\mathbf{4}$ & \\
\hline Irrelevante & & & & & Muito importante \\
\hline
\end{tabular}

6. Em sua opinião, o instrumento Estudo de Impacto Ambiental/Relatório de Impacto Ambiental (EIA/RIMA) é adequado para a avaliação dos impactos ambientais para a liberação de plantio de PGMs em escala comercial, quanto aos seguintes aspectos:

a-) consideração dos impactos ambientais cumulativos

( ) $\mathrm{Sim}$

( ) Não

b-) consideração das alternativas tecnológicas à transgenia

( ) $\operatorname{Sim}$

( ) Não

c-) consideração das alternativas locacionais

( ) $\mathrm{Sim}$

( ) Não

d-) consideração (análise conjunta) das Políticas, Planos e Programas relacionados à proposta em avaliação

( ) $\mathrm{Sim}$

( ) Não

e-) monitoramento pós-comercial da PGM

( ) $\mathrm{Sim}$

( ) Não

f-) participação social nas tomadas de decisão 
( ) $\operatorname{Sim}$

( ) Não

7. Em sua opinião, o instrumento Análise de Risco (AR) é adequado para a avaliação dos impactos ambientais em escala comercial de PGMs, nos seguintes aspectos?

a-) consideração dos impactos ambientais cumulativos

( ) $\operatorname{Sim}$

( ) Não

b-) consideração das alternativas tecnológicas à transgenia

( ) $\operatorname{Sim}$

( ) Não

c-) consideração das alternativas locacionais

( ) $\operatorname{Sim}$

( ) Não

d-) consideração das Políticas, Planos e Programas relacionados à proposta em avaliação
( ) $\operatorname{Sim}$
( ) Não
e-) monitoramento pós-comercial da PGM
( ) $\operatorname{Sim}$
( ) Não
f-) participação social nas tomadas de decisão
( ) $\operatorname{Sim}$
( ) Não

8. Você conhece algum instrumento de avaliação de impacto ambiental que aborde os aspectos de "a" até "f" contemplados nas questões 6 e 7 em relação ao plantio em escala comercial de PGMs? 
9. Em sua opinião, quais das seguintes instituições deveriam ter o poder decisório final a respeito da liberação comercial (em larga escala) de PGMs?

(Pode ser escolhida mais de uma alternativa)
( ) CTNBio
( ) Conselho Nacional de Biossegurança
( ) Ministério do Meio Ambiente,
( ) Ministério Agricultura e Desenvolvimento Agrário,
( ) Ministério Ciência e Tecnologia,
( ) Ministério Saúde,
( ) uma avaliação conjunta de todos eles.
( ) Outras - especificando-as:

10. Como você avalia os seguintes aspectos do processo decisório envolvendo a liberação em escala comercial para o plantio de PGMs no Brasil?

$$
\text { (1 =insatisfatório e } 4 \text { = bastante satisfatório) }
$$

a-) a atuação conjunta das instituições envolvidas na gestão dos OGMs (CTNBio, CNBS e órgãos de registro e fiscalização) para a liberação.

\begin{tabular}{|l|l|l|l|l|l|}
\hline & 1 & 2 & 3 & 4 & \\
\hline Insatisfatório & & & & & Bastante satisfatório \\
\hline
\end{tabular}

b-) legitimidade (em relação à participação da sociedade e dos interessados) do processo decisório da liberação.

\begin{tabular}{|l|l|l|l|l|l|}
\hline & $\mathbf{1}$ & $\mathbf{2}$ & $\mathbf{3}$ & $\mathbf{4}$ & \\
\hline Insatisfatório & & & & & Bastante satisfatório \\
\hline
\end{tabular}

c-) transparência (acesso às informações, aos documentos, aos pareceres e resultados de audiência pública) do processo decisório: 


\begin{tabular}{|l|l|l|l|l|l|}
\hline & $\mathbf{1}$ & $\mathbf{2}$ & $\mathbf{3}$ & $\mathbf{4}$ & \\
\hline Insatisfatório & & & & & Bastante satisfatório \\
\hline
\end{tabular}

d-) inserção dos aspectos ambientais nas tomadas de decisão:

\begin{tabular}{|l|l|l|l|l|l|}
\hline & $\mathbf{1}$ & $\mathbf{2}$ & $\mathbf{3}$ & $\mathbf{4}$ & \\
\hline Insatisfatório & & & & & Bastante satisfatório \\
\hline
\end{tabular}

e-) inserção dos aspectos sociais e culturais nas tomadas de decisão:

\begin{tabular}{|l|l|l|l|l|l|}
\hline & $\mathbf{1}$ & $\mathbf{2}$ & $\mathbf{3}$ & $\mathbf{4}$ & \\
\hline Insatisfatório & & & & & Bastante satisfatório \\
\hline
\end{tabular}

f-) inserção dos aspectos econômicos de todos os envolvidos nas tomadas de decisão:

\begin{tabular}{|l|l|l|l|l|l|}
\hline & $\mathbf{1}$ & $\mathbf{2}$ & $\mathbf{3}$ & $\mathbf{4}$ & \\
\hline Insatisfatório & & & & & Bastante satisfatório \\
\hline
\end{tabular}

g-) a efetiva implantação do Sistema de Informações em Biossegurança, exigido pela Lei no. 11.105/05 para a tomada de decisão e o processo sobre a liberação em todas as suas etapas (monitoramento, por exemplo).

\begin{tabular}{|l|l|l|l|l|l|}
\hline & $\mathbf{1}$ & $\mathbf{2}$ & $\mathbf{3}$ & $\mathbf{4}$ & \\
\hline Insatisfatório & & & & & Bastante satisfatório \\
\hline
\end{tabular}

h-) fiscalização das atividades após a liberação comercial de PGMs

\begin{tabular}{|l|l|l|l|l|l|}
\hline & $\mathbf{1}$ & $\mathbf{2}$ & $\mathbf{3}$ & $\mathbf{4}$ & \\
\hline Insatisfatório & & & & & Bastante satisfatório \\
\hline
\end{tabular}


i-) consideração de medidas preventivas aos possíveis impactos negativos dos OGMs no processo de avaliação

\begin{tabular}{|l|l|l|l|l|l|}
\hline & $\mathbf{1}$ & $\mathbf{2}$ & $\mathbf{3}$ & $\mathbf{4}$ & \\
\hline Insatisfatório & & & & & Bastante satisfatório \\
\hline
\end{tabular}

j-) análise conjunta de Políticas, Planos e Programas que possuem alguma relação com a liberação comercial de OGMs:

\begin{tabular}{|l|l|l|l|l|l|}
\hline & $\mathbf{1}$ & $\mathbf{2}$ & $\mathbf{3}$ & $\mathbf{4}$ & \\
\hline Insatisfatório & & & & & Bastante satisfatório \\
\hline
\end{tabular}

Utilize o espaço a seguir para fazer considerações que julga pertinentes e importantes: 